Florida International University FIU Digital Commons

\title{
Conservative Right-Wing Protest Rhetoric in the Cold War Era of Segregationist Mobilization
}

Devon A. Wright

dwrig001@fiu.edu

DOI: 10.25148 /etd.FIDC001937

Follow this and additional works at: https://digitalcommons.fiu.edu/etd

Part of the Inequality and Stratification Commons, Political History Commons, Politics and Social Change Commons, Quantitative, Qualitative, Comparative, and Historical Methodologies

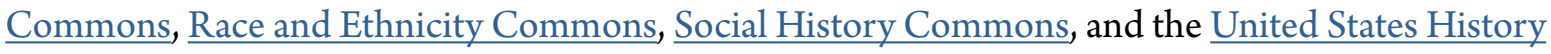
Commons

\section{Recommended Citation}

Wright, Devon A., "Conservative Right-Wing Protest Rhetoric in the Cold War Era of Segregationist Mobilization" (2017). FIU Electronic Theses and Dissertations. 3457.

https://digitalcommons.fiu.edu/etd/3457 


\title{
FLORIDA INTERNATIONAL UNIVERSITY
}

Miami, Florida

CONSERVATIVE RIGHT-WING PROTEST RHETORIC IN THE COLD WAR ERA OF SEGREGATIONIST MOBILIZATION

\author{
A dissertation submitted in partial fulfillment of the \\ requirements for the degree of \\ DOCTOR OF PHILOSOPHY \\ in \\ COMPARATIVE SOCIOLOGY \\ by \\ Devon A. Wright
}


To: Dean John F. Stack, Jr.

Steven J. Green School of International and Public Affairs

This dissertation, written by Devon A. Wright, and entitled Conservative Right-Wing Protest Rhetoric in the Cold War Era of Segregationist Mobilization, having been approved in respect to style and intellectual content, is referred to you for judgment.

We have read this dissertation and recommend that it be approved.

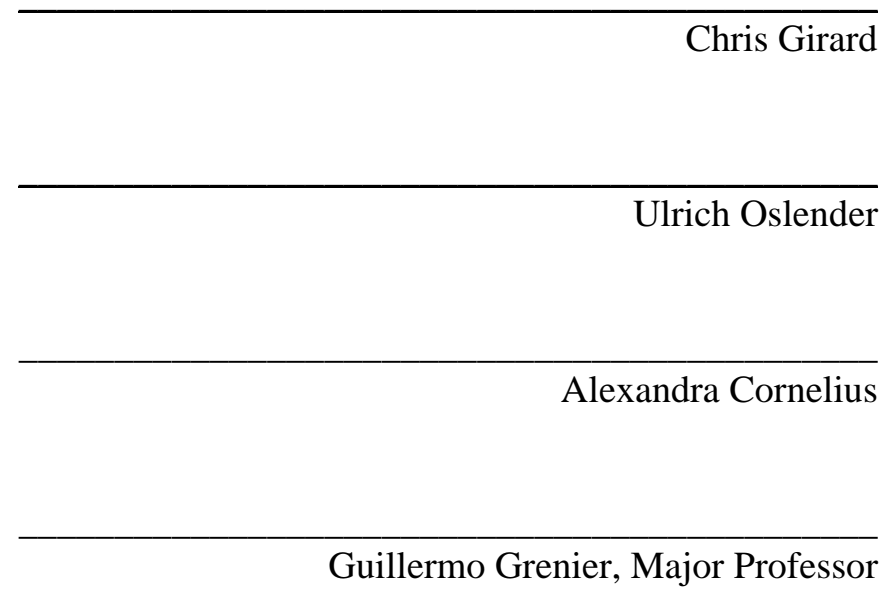

Date of Defense: June 16, 2017

The dissertation of Devon A. Wright is approved.

Dean John F. Stack Jr. Steven J. Green School of International and Public Affairs

Andrés G. Gil

Vice President for Research and Economic Development and Dean of the University Graduate School

Florida International University, 2017 
(C) Copyright 2017 by Devon A. Wright

All rights reserved. 


\section{ACKNOWLEDGMENTS}

I wish to thank the members of my committee for their support, brutal honesty and priceless wisdom. I thank Dr. Guillermo Grenier for getting me through the difficulties of the comprehensive exams, the dissertation proposal defense and finally the dissertation research and writing process itself, and for giving me the space needed to struggle through the project. I am greatly indebted to Dr. Chris Girard’s mentorship. The 2015 Chicago visit to the American Sociological Association's annual meeting was a critical moment that shifted my sense of purpose and confidence as a social science researcher. I thank Dr. Ulrich Oslender for the lengthy conversations in his office about the direction of my research, my career, and for helping me to understand the significance of my research. I thank Dr. Alexandra Cornelius for her discussions with me about the progress of my research, and the career advice about how to craft my identity as an academic. I thank Dr. Dennis Wiedman for his assistance with the NVIVO coding program used in my qualitative analysis. Finally, I thank the following institutions for providing me the materials examined in this research: Mississippi Department of Archives and History Special Collections; University of Mississippi Libraries Digital Collections; and Duke University Rubenstein Library Archives. 
ABSTRACT OF THE DISSERTATION

CONSERVATIVE RIGHT-WING PROTEST RHETORIC IN THE COLD WAR ERA OF

SEGREGATIONIST MOBILIZATION

by

Devon A. Wright

Florida International University, 2017

Miami, Florida

Professor Guillermo Grenier, Major Professor

In the early Cold War decades, the Citizens' Councils of America (CCA) became the flagship conservative right-wing social movement organization (SMO). As part of its organizational activities, it engaged in a highly sophisticated propaganda effort to mobilize prosegregationist opinion, merging traditional racist arguments with modern Cold War geopolitics to characterize civil rights activism and federal civil rights reforms as an effort to bring about a tyrannical, Soviet-inspired, dictatorship. Through a content discourse analysis, this research aims to contribute to understanding what factors determine how SMO’s deploy propaganda rhetoric. The main hypothesis is that geopolitical factors, defined here as specific geographic contexts in which sociopolitical issues are situated and from which propaganda rhetoric is deployed, are influential determinants. Since SMO rhetoric reflects its larger ideological orientation, SMO ideology is also influenced by geopolitical factors. For comparative analysis, propaganda literature from the Ku Klux Klan, as well as elite segregationist rhetoric from the same period is included. Relying on frame theory all rhetoric is quantitatively analyzed centering on the question of what factors drive SMO frame messaging. To contribute to frame theory a concept is proposed called frame constellation, which is a web of SMO frame rhetoric and symbolism that functions as an overlapping, intersecting and interrelated system of ideas which revolve around a central intellectual logic for collective action. 


\section{TABLE OF CONTENTS}

\section{CHAPTER}

PAGE

I. SEGREGATIONIST PROTEST IN THE COLD WAR-CIVIL RIGHTS ERA.......................... 1

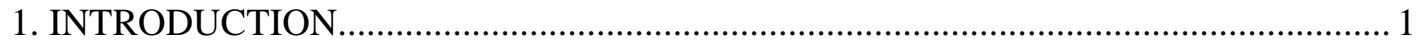

2. UNDERSTANDING U.S. CONSERVATIVE RIGHT-WING MOVEMENTS .............. 5

2.1 An Enduring Set of Analytical Blinders and U.S. Conservative Right-wing SM's...... 6

2.2 Defining the CCA as a Countermovement and its Significance in U.S. Politics ........... 8

2.3 The CCA as an Elite-Driven Countermovement with Institutional Activists............... 9

2.4 Not a Structural Analysis: Culture beyond Institutionalized Politics ......................... 11

2.5 The Broader Contentious Politics of the CCA.............................................................. 15

3. A MASSIVE OVERSIGHT BY SOCIAL MOVEMENT SCHOLARS ........................ 17

3.1 Civil Rights and Segregationist Mobilization in Cold War Context............................ 17

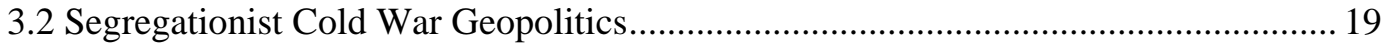

3.3 Segregationist Anti-Communism in America.............................................20

4. MASSIVE RESISTANCE AND THE ERA OF SEGREGATIONIST PROTEST ........ 22

4.1 Historiography on Massive Resistance ...................................................................... 22

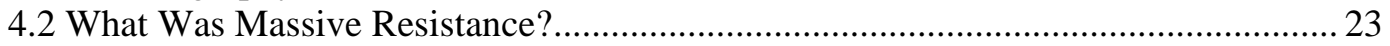

4.3 The Dixiecrat Revolt as a Precursor to Massive Resistance ...................................... 24

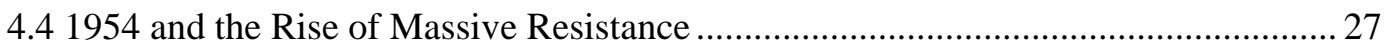

4.5. Massive Resistance and Elite Institutional Opposition................................................ 30

4.6. Massive Resistance and Grassroots Organizations ................................................. 31

4.7. The Ideology and Rhetoric of Massive Resistance ................................................... 35

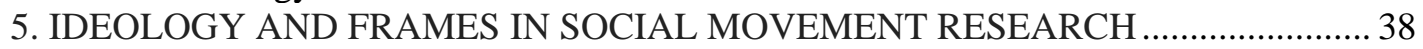

6. THE SEGREGATIONIST FRAME CONSTELLATION............................................. 41

II. WHITE SUPREMACIST IDEOLOGY AND SEGREGATIONIST FRAMES ...................... 43

1. THE PROPAGANDA VOICE OF THE SEGREGATIONIST MOVEMENT ................ 43

2. SEGREGATIONIST FRAMES AS RECOGNIZED IN THE HISTORIOGRAPHY .... 44

2.1 The Citizens' Council and the Anti-Communist Frame in Historical Context ........... 44

2.2 The Citizens' Council and the Anti-Miscegenation Frame in Historical Context ...... 47

2.3 The Citizens' Council and the Christian-Biblical Frame in Historical Context .......... 51

2.4 The Citizens' Council and the Science Frame in Historical Context........................... 54

2.5 The Citizens' Council and the States' Rights Frame in Historical Context................. 56

2.6 The Citizens' Council and the Outside-Agitator Frame in Historical Context ............ 58

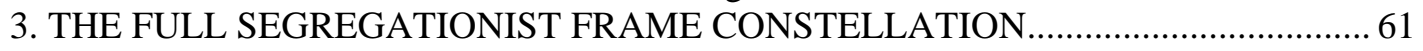

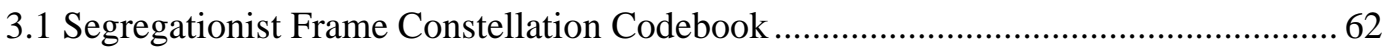

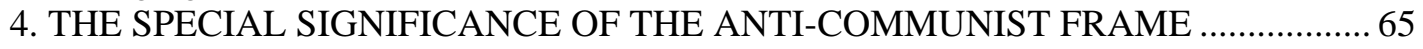

5. A BRIEF HISTORY OF THE CCA PROPAGANDA MEDIA CAMPAIGN.................66

III. CITIZENS' COUNCILS OF AMERICA OFFICIAL PAPER (1955-1961) .............................. 69

1. REFINING THE SEGREGATIONIST FRAME CONSTELLATION …............................ 69

2. OVERVIEW OF THE CITIZENS’ COUNCIL OFFICIAL PAPER …............................. 70

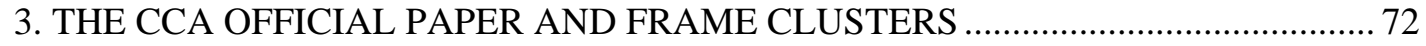

3.1 Frame Cluster 1: The Negro and the Segregationist Imperative............................... 73

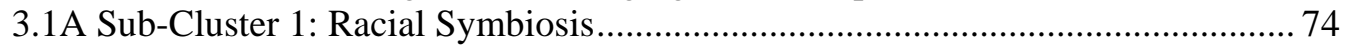

3.1B Sub-Cluster 2: Negro Depravity and Primitivism ................................................. 79

3.2 Frame Cluster 2: Ideological Un-Americanism ........................................................... 87

3.2A Ideological Un-Americanism and the Anti-Communist Frame .......................... 88 


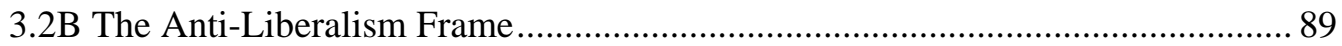

3.2C The Anti-Left Frame …................................................................................... 93

3.2D The Anti-Socialism Frame ................................................................................ 95

3.3 Frame Cluster 3: Struggle for the Preservation of Freedom ........................................ 98

3.3A Personal Freedoms Frame ................................................................................... 99

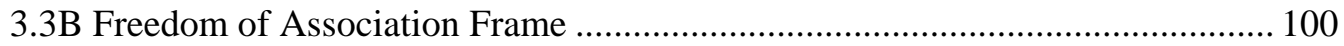

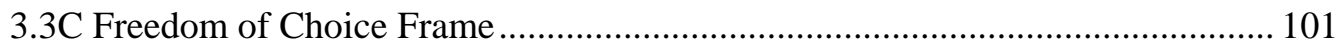

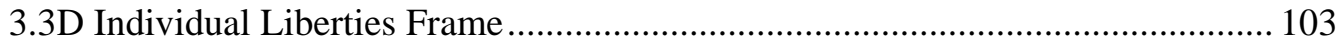

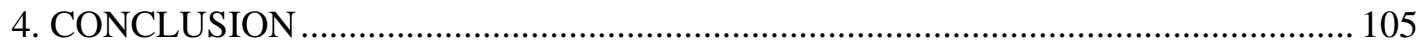

IV. CITIZENS' COUNCILS OF AMERICA BROADCAST MEDIA (1955-1966).................. 106

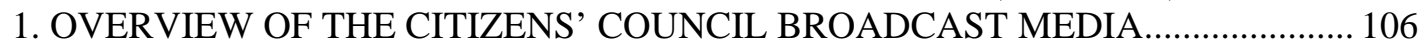

2. COLD WAR ANTI-COMMUNISM OF THE CCA BROADCAST MEDIA ................ 109

2.1 Anti-Communist Foreign Policy Critiques on the Citizens' Council Forum............. 112

2.2 Defense of Global White Rule against Communist Racial Anarchy ......................... 118

2.3 The Threat of Ideological Un-Americanism ........................................................ 126

2.4 Federal Government Tyranny and the Struggle for the Preservation of Freedom .... 140

2.5 Segregationist Scientists and the Effort against Tyrannical Equalitarian Dogma .... 151

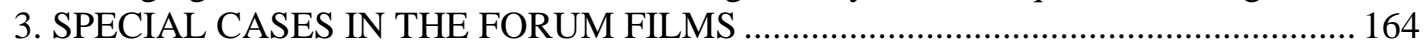

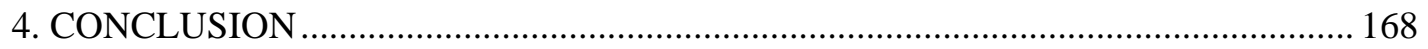

V. COLD WAR GEOPOLITICAL FACTORS IN SEGREGATIONIST RHETORIC............... 169

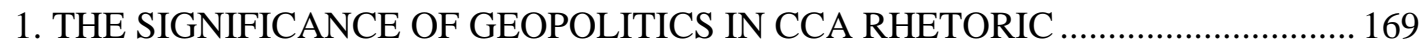

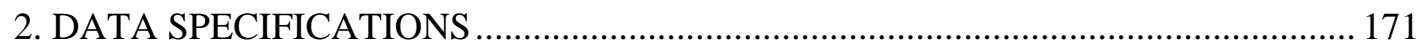

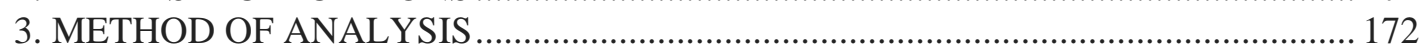

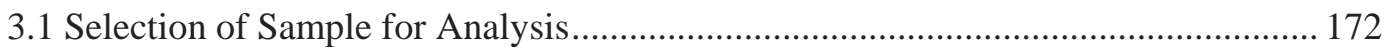

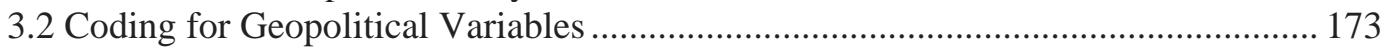

3.3 Average Percentage Coverage of Geopolitical Variables for Six Frames ................ 174

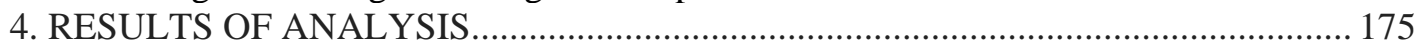

4.1 Results for Data Set 1: The Citizens' Council (1955-1961) ................................... 175

4.2 Results for Data Set 2: Citizens’ Council Forum (1955-1966)................................ 177

4.3 Results for Data Set 3: The Citizen (1961-1979).................................................. 179

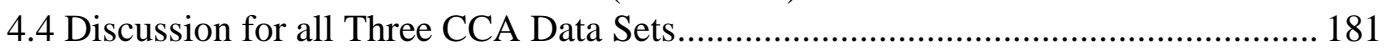

5. COMPARATIVE ANALYSIS OF SEGREGATIONIST PROTEST FRAMING........ 181

5.1 Qualitative Comparison and Contrast between CCA and KKK Rhetoric ................. 181

5.2 Quantitative Comparison and Contrast between CCA and KKK Rhetoric ............... 183

5.3 Results for Data Set 4: Various Mississippi Ku Klux Klan literature (1960s) .......... 184

5.4 Qualitative Comparison and Contrast between CCA and Elite Rhetoric .................. 185

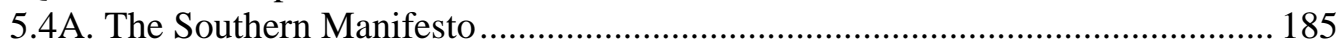

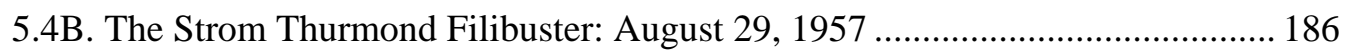

5.5 Quantitative Comparison and Contrast between CCA and Elite Rhetoric ................ 188

5.6 Results for Data Set 5: Elite Segregationist Rhetoric .............................................. 188

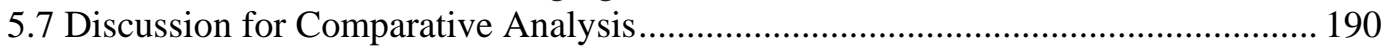

6. SUMMARY OF RESEARCH AND FUTURE POSSIBLE DIRECTIONS .................. 191

7. CONCLUSION: RECTIFYING THE MASSIVE OVERSIGHT …............................... 192

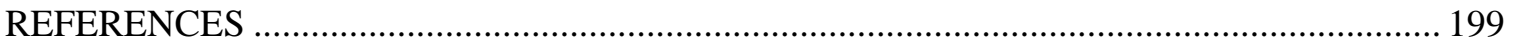

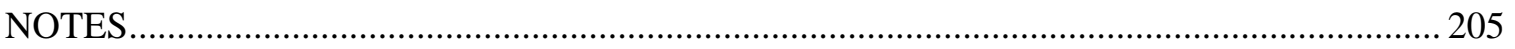

VITA 


\section{LIST OF TABLES}

TABLE

PAGE

1. Table 1 Main Frames and Coding References for The Citizens' Council (1955-1961) .......... 194

2. Table 2 Main Frames and Coding References for Citizens' Council Forum (1955-1966)...... 195

3. Table 3 Main Frames and Coding References The Citizen (1961-1979) ............................... 195

4. Table 4 Main Frames and Coding References for Ku Klux Klan literature (1960s) ............... 196

5. Table 5 Main Frames and Coding References Elite Segregationist Rhetoric ......................... 197 


\section{LIST OF FIGURES}

TABLE

PAGE

1. Figure 1 Geo Contexts for 6 Highest Frames of The Citizens' Council (1955-1961) .............. 176

2. Figure 2 Averages of Aggregated Geo Contexts of The Citizens' Council (1955-1961)........ 177

3. Figure 3 Geo Contexts for 6 Highest Frames of Citizens’ Council Forum (1955-1966)......... 178

4. Figure 4 Averages of Aggregated Geo Contexts of Citizens’ Council Forum (1955-1966) ... 179

5. Figure 5 Geo Contexts for 6 Highest Frames of The Citizen (1961-1979) ….......................... 180

6. Figure 6 Averages of Aggregated Geo Contexts of The Citizen (1961-1979) ........................ 180

7. Figure 7 Geo Contexts for 6 Highest Frames of Ku Klux Klan Literature (1960s)................. 184

8. Figure 8 Averages of Aggregated Geo Contexts of Ku Klux Klan Literature (1960s) ........... 185

9. Figure 9 Geo Contexts for 6 Highest Frames of Elite Segregationist Rhetoric ....................... 189

10. Figure 10 Averages of Aggregated Geo Contexts of Elite Segregationist Rhetoric ............... 190 


\section{ABBREVIATIONS AND ACRONYMS}

$\begin{array}{ll}\text { CCA } & \text { Citizens' Councils of America } \\ \text { BROWN } & \text { Brown versus the Board of Education of Topeka, Kansas (1954) } \\ \text { KKK } & \text { Ku Klux Klan } \\ \text { SM } & \text { Social Movement } \\ \text { SMO } & \text { Social Movement Organization }\end{array}$




\section{CHAPTER I. SEGREGATIONIST PROTEST IN THE COLD WAR-CIVIL RIGHTS ERA}

Integration represents darkness, regimentation, totalitarianism, communism and destruction. Segregation represents the freedom to choose one's associates, Americanism, state sovereignty and the survival of the white race. These two ideologies are now engaged in mortal conflict and only one can survive. They cannot be fused any more than day can exist in the night. The twilight of this great nation would certainly follow. 'Choose ye this day whom you will serve' (The Citizens' Council 1955). ${ }^{1}$

\section{INTRODUCTION}

In the aftermath of Brown v. Board of Education of Topeka, Kansas 1954 (Brown), in which the United States Supreme Court ruled segregated public education to be unconstitutional, a powerful resistance movement began to take shape in the South. Reaching the height of its potency in the late 1960s, historians understand this period of intense conservative right-wing institutionalized political action and grassroots mobilization as 'massive resistance' (Bartley 1969; Day 2014; Lewis 2004 \& 2006; McMillen 1971; Parkinson 2004; Wallace 2013; Ward 2011; Webb 2005; Wilhoit 1973). The term was a self-imposed moniker that named the white southern insurgency against civil rights activism and federal civil rights reforms. At the center of this counter effort was an organization originally called the White Citizens' Councils. Sensitive to being perceived as a racist and extremist organization, and wanting to project a public image of mainstream, reasonable-minded white Americans engaged in civic activism, it soon became the Citizens' Councils, which later grew into the official Citizens' Councils of America (CCA or Council). First formed in Indianola, Mississippi 1954, the CCA became the "dominant submovement during the 1950s and 1960s” (Diamond 1995:10), represented the vanguard rank-andfile of the 'massive resistance' movement (Bartley 1969), and was the most organized, widespread and politically influential of segregationist organizations (McMillen 1971).

As part of its organizational activities, the CCA engaged in a highly sophisticated propaganda effort, including three major media platforms, its official paper, The Citizens' 
Council (1955-1961), its broadcast series, Citizens' Council Forum (1955-1966), and the official journal of the Citizens' Council, The Citizen (1961-1979). This research seeks to makes sense of the ideology and rhetoric of the CCA's propaganda machine, as represented in the opening quote. The Council wanted to consolidate and capitalize on white fears of blurring racial boundaries and focus these passions into a concerted struggle against integration and racial equality in favor of conformity with traditional southern white sensibilities. Segregationist sentiments reflected a deep-rooted history of Civil-War era Confederate nationalism, but they also mirrored every bit as much about post-World War II mainstream American nationalism. Caught up in the patriotic hysteria of anti-Communism, the CCA, like the larger southern white resistance movement, devoted much of its attention to the alarm that outside forces, namely Soviets infiltrators, were orchestrating societal collapse from within the nation. The CCA's propaganda messaging must therefore be understood in the context of larger Cold War geopolitics. Although it was a white southern regional sub-movement against civil rights racial liberalism, the CCA’s ideology of white supremacy centered on the intersection between national and international developments, seeing them as critical in the defense of the white power structure.

The CCA should be understood as a conservative right-wing social movement organization (SMO), one that "acts on behalf of relatively advantaged groups with the goal of preserving, restoring, and expanding the rights and privileges of its members and constituents...” and "attempt [s] to deny similar rights and privileges to other groups in society (McVeigh 2009:32).” It has also been noted that, “most right-wing groups are viciously white supremacist and anti-Semitic, regarding non-whites and Jews as inferior, destructive, and fearsome and seeking to preserve the power and privileges of white Aryans” (Blee and Creasap 2010:275). Like Lo (1982), I limit this discussion of conservative and right-wing movements to the United States with emphasis on the post-1970 literature (Lo 1982:107). The most notorious conservative rightwing SMO in American history that fits the above characterizations is the Ku Klux Klan (KKK or 
Klan), which is worth comparing and contrasting with the CCA. In the post-World War II era, like the CCA, the KKK organized itself as a defensive response to civil rights activism and federal civil rights forms. The Klan however, unlike the CCA, had a long prior history as a force to protect white Anglo Protestant dominance over American institutions. In particular, the Klan that existed from 1915 to 1924 was not only the most powerful era of all Klan activity, numbering in the millions, but was the most politically influential conservative right-wing movement of any post-Civil War period in American history (McVeigh 1999). However, the 1960s era Klan primarily appealed to and drew its support from working-class whites (Cunningham 2004), whereas the CCA and its local Councils maintained a monopoly on the middle class, business elites and political figures who saw that organization as more "respectable" than the Klan (McMillen 1971). Civil rights era Klan mobilization did not ignite immediately after the Brown decision, but it did reemerge as a potent, militant organization by the early 1960s (Cunningham 2013). In the entire post-1954 civil rights era however, the CCA dominated grassroots opposition, although it was largely driven by business and political elites.

Like any other SMO, from liberal/left-wing to conservative/right-wing forms, the CCA rooted its propaganda rhetoric and other symbolism in a broader movement ideology in order to advance its agenda. Through a qualitative content discourse analysis, the aim of this research is to contribute to understanding what factors determine how SMO's deploy propaganda rhetoric. The main hypothesis is that geopolitical factors, defined here as specific geographic contexts in which sociopolitical issues are situated and from which propaganda rhetoric is deployed, are influential determinants. Since SMO rhetoric reflects its larger ideological orientation, SMO ideology is also influenced by geopolitical factors. For comparative analysis, propaganda literature from the KKK of the post-World War II civil rights period is included, as well as elite segregationist rhetoric from the same 'massive resistance' era. Relying on frame theory, CCA, KKK, and elite segregationist rhetoric are all analyzed centering on the question of what factors drive SMO 
frame messaging. Through a meticulous deconstruction of the intricate web of segregationist frame argumentation, this study aims to contribute to frame theory by introducing a concept called frame constellation, a web of SMO frame rhetoric and symbolism that functions as an overlapping, intersecting and interrelated system of ideas which revolve around a central intellectual logic for collective action. The CCA's (and broader segregationist movement’s), central intellectual logic was white supremacist ideology, a belief system rooted in the notion that whites as a race are distinct from all other racial groups by their presumed superiority, especially with regard to intelligence. The CCA's frames were its segregationist arguments, which consisted of any, and all rhetorical and symbolic defenses of the social system of racial segregation as defined by the privileging of whiteness and oppression of non-whites, especially blacks.

The scholarly significance and necessity for publication of this research is summarized in the following. No major book-length publication has been produced that focuses exclusively on the CCA since Neil R. McMillen’s 1971 work, which was released while that organization was still in existence producing propaganda material until it dissolved in the early 1980s, taking on a new form in the Council of Conservative Citizens in 1985. No publication has yet systematically analyzed in meticulous detail, the CCA's propaganda campaign and its three main media platforms previously described. Few sociological insights have been brought to bear on the significance of the CCA, to be elaborated upon in the next section, which is a glaring oversight by social movement scholars in particular, who have largely neglected the entire post-1954 segregationist massive resistance movement except for studies on the post-World War II civil rights era Klan. Few social movement researchers, especially those who specialize in conservative right-wing collective action, have published on the significance of post-1954 segregationist mobilization in Cold War geopolitical context. Finally, no social movement scholar has centered their research on the notion that white southern opponents of civil rights were not merely regional in the scope of their activism and ideological orientation, but instead were 
thoroughly engaged in international issues of the day in their defense of the global white power structure against Soviet Communism.

\section{UNDERSTANDING U.S. CONSERVATIVE RIGHT-WING MOVEMENTS}

In this section, it is argued that social movement scholarship, specifically that which is focused on collective protest in the U.S. socio-political context and historical tradition, is severely lacking in several respects. Firstly, there is an analytical bias in favor of liberal progressive movements and against conservative right wings forms. The scant attention to segregationist mobilization in the post-WWII civil rights era by social movement scholars is because of a favorable orientation toward examining liberal progressive social movements of that period as having a "legitimate" grievance against state oppression. Social movement theories, as they have developed alongside the liberal progressive challenges from below, have adapted to the paradigm of treating such movements as natural and predictable outcomes of situations where forces of oppression in society create pressures that lead to grievance-based movements. The lens with which social movement scholars have sought to identify social movements is clouded by a struggle-from-below against oppression perspective. This view is detrimental to understanding instances of collective protest by activists who employ the rhetoric of grievance against perceived tyranny, but who also enjoy a relatively privileged position in the social hierarchy, as compared to social groups most often regarded as underprivileged in terms of class, gender, race and ethnicity.

There also is a tendency to erroneously conceptualize 'countermovements' as synonymous with conservative right-wing social movements, and to see 'genuine' social movements as those driven exclusively or primarily by 'grass-roots” activists without the involvement of elite actors, especially politicians. In the discussion of theory, it is also made clear that this study is not a 'structural' analysis seeking to understand the emergence of social movements. Instead, the focus is on the significance of collective identity, grievance, emotion and 
frames in social movement rhetoric and ideology. Lastly, there is a misconception of 'contentious politics' as the socio-political conditions that give rise to challengers from below, or activists from outside established political institutions. In fact, conservative right-wing social movements like the CCA, operated from a decidedly politically advantageous position with the benefit of the traditional segregationist power structure at the state level, and with involvement by political elites at the federal level; a point that will be more fully explained in the section on 'massive resistance'.

2.1 An Enduring Set of Analytical Blinders and U.S. Conservative Right-wing SM’s

While there is embarrassingly little attention by researchers of U.S. social movements to segregationist collective action, Diamond (1995) has appeared to produce the only comprehensive treatment of conservative right-wing mobilization of that era, placing the CCA, among other organizations, at the center of a broader conflagration. Diamond asserts that, "most scholarship about the Right has been ahistorical and noncomparative” (Diamond 1995:4). She also contends that social movement scholarship has not sought to understand conservative right-wing movements, but instead relies on what essentially are "pejorative terms” such as "radical” and “extremist” which mischaracterize such instances of collective action as existing outside legitimate established political institutions. However, those movements had indeed largely engaged in "mostly legitimate pressure tactics like voting, lobbying, and persuading supporters through media campaigns, and... mutually beneficial ties with established political elites” (Diamond 1995:5). The “radical-extremist” Right lens, according to Diamond, has become an “enduring set of analytical blinders” first advanced in the 1950s by major social thinkers of the day, and resurrected in the 1990s by liberal and centrist political organizations to advance their causes against evangelical Christians. This analytical blind spot also persists in contemporary scholarship where, “even the best scholarly research has tended to focus disproportionately on social movements opposed to the status quo” (Diamond 1995:6). 
McVeigh (1999 \& 2009), seems to make the strongest indictment of researchers for their shortcomings with regard to U.S. conservative right-wing movements. He contends that the overwhelming focus has tended to be on liberal-progressive reform movements that seek to challenge the existing status quo on power relations from below. Conservative right-wing movements, as McVeigh observes, operate from a relatively privileged position in society, often seeking to preserve the status quo in ways that deny the same privileges to historically disadvantaged groups. Like Diamond, McVeigh also argues that disproportionate scholarly attention to liberal progressive reform movements has perhaps blinded social movement analysts from appreciating the sophisticated ways in which conservative right-wing SMO’s operate, employing ideology and rhetoric with strategic rationalism. Instead, these movements have often been dismissed as mere reactionary, purely emotionally driven and irrational, especially those that align themselves with racism, ultra-patriotism and xenophobia (McVeigh 1999 and 2009). Nonetheless, movements which embrace such ‘isms’ are informed by systems of knowledge with deep socio-historical roots that retain their own intellectual logic for collective action. As Adams and Roscigno (2005) observe, "Unlike liberal social movements, which are often lauded as progressive initiatives responding to a variety of social injustices, conservative social movements are usually regarded as irrationally motivated exercises in intolerance” (Roscigno 2005:761).

In critiquing the dominant social movement theories since the 1970s, especially resource mobilization and political opportunity theory, McVeigh makes the point that scholars reject the characterization of social movements by classical theorists as expressions of social strain, deviancy or rationality, but “....are less likely to object when participants in extreme conservative movements are characterized as irrational and marginalized” (McVeigh 2009:36). In McVeigh’s analysis of the early $20^{\text {th }}$ century Klan, he pushes aside the idea that resources were unavailable or that political opportunities were unfavorable prior to Klan mobilization. Instead, he urges us to "reconsider the possibility that collective grievances can play an important causal role when it 
comes to explaining right-wing mobilization.” McVeigh takes particular aim at political opportunity theory as inadequate for analyzing conservative right-wing movements because the political structure is not shifting in ways favorable to their spectrum of the political ideology. Rather, their emergence is often, but not always, a reaction to the perceived contraction of political opportunities, which have been expanded to social groups traditionally denied such benefits in society. To McVeigh, the key to understanding the rise of conservative right-wing movements is examining the source of their grievances (McVeigh 1999:1463).

2.2 Defining the CCA as a Countermovement and its Significance in U.S. Politics

As previously explained, an analytical blind spot in social movement research has produced a tendency to narrowly conceptualize conservative right-wing movements as merely reactionary and therefore are often regarded as false social movements. Instead, these types of collective protest are pejoratively thought to be "countermovements" in the sense that they exist only to prevent the success of, or retard previous gains on the part of liberal-progressive movements. For example, Chafetz and Dworkin (1987) make the assumption that, "social movements are intrinsically anti-institutional in character (that is, antiestablishment)...” and “... countermovements are proinstitutional in character, that is, supportive of the establishment and the status quo or status ante...” (Chafetz and Dworkin 1987:35). It should be clarified however, that countermovements are not limited to that of conservative right-wing forms, and neither are liberal-progressive movements the only genuine social movement type. Jasper (2014), in critiquing the scholarship, clarifies that,

... although many scholars define movements as progressive, dismissing regressive efforts as countermovements, this distinction seems arbitrary (not to mention the unfortunate effect that different tools are then used to analyze the two types). The anti-abortion movement is just as much a social movement as the abortion-rights movement, even if it wishes to turn back the clock on human rights... (Jasper 2014:5). 
A countermovement is understood here as one "which mobilizes against another social movement” (Lo 1982:108). Meyer (2015) explains that, “A countermovement is interested in the same issues as the social movement it responds to but wants everything to turn out differently" (Meyer 2015:212). He also mentions the post-WWII era of civil rights movement activists versus the segregationist countermovement, most prominently the Council, which "wanted to maintain legally supported segregation and, more generally, to stifle a movement that wanted change” (Meyer 2015:212).

McAdam (1982 \& 1983) similarly identifies this interactive movement countermovement dynamic in explaining the correlated processes of what he calls 'tactical innovation' and 'tactical adaptation'. During the civil rights movement, civil rights organizations, with the occasional but strategically significant assistance of the federal government, operated within the ‘Cold War template’ (McAdam 1982), while pro-segregationists engaged in an interactive oppositional dynamic which shaped the two opposing social movements. Together these opposing sides came to “define an ongoing process of tactical interaction” where civil rights activists and pro-segregationists sought "in chess-like fashion to offset the moves of the other.” This interactive dynamic not only affected "the pace and outcome of insurgency," but defined the opposing movements as well (McAdam 1983:736). The movement-countermovement dynamic that characterized the post-War period, according to Meyer, is the defining feature of U.S. political culture. "In fact,” he states, "the development of countermovements that engage in social protest over the long haul has become the rule, rather than the exception, of American politics” (Meyer 2015:212).

\subsection{The CCA as an Elite-Driven Countermovement with Institutional Activists}

The CCA was decidedly focused on legislative outcomes at the federal level, concerning itself with thwarting the passage of civil rights bills that would run counter to its segregationist vision of the nation. To the extent that the CCA maintained a close organizational relationship 
with segregationist politicians (Wilhoit 1973:113-114), and functioned as a political instrument of southern white business and political elites (Ward 2011:160), it can be questioned as to whether the CCA was an authentic 'grass-roots' SMO. To sway public opinion in hopes of preventing legislative progress for black civil rights, the CCA wielded a complex media machine that greatly benefitted from the participation of political elites at the state and federal levels intimately involved in the effort to preserve segregation. Such a phenomenon has been discussed in the social movement literature. As one scholar notes, “...under specific conditions, the power elite may become active mobilizers, leaders, and supporters of countermovements...” (Pichardo 1995:21), and this was certainly the case with the CCA. With regard to social movements in general, institutional activism can become and often is a prominent feature.

Social movements do not engage strictly in noninstitutional behavior. Institutional channels are not abandoned nor forsaken. For example, the civil rights movement, in addition to noninstitutional tactics, pursued civil suits and legislation. One would expect such a dualistic approach to be employed by elites who have access to institutional channels and are very likely to use these channels to their fullest effect. A close level of cooperation between some institutional agencies and actors and elite-driven movements should in fact be expected (Pichardo 1995:35).

In fact, the CCA featured a number of prominent U.S. political elites who participated in organizational activities while maintaining their role as public servants in Congress. Most notably among them, U.S. Senator Strom Thurmond appeared as a regular guest commentator on the CCA's Forum television program. Santoro and McGuire (1997), use the term "institutional activists” to describe “social movement participants who occupy formal statuses within the government and who pursue social movement goals through conventional bureaucratic channels.” Taking critical aim at resource mobilization theory, Santoro and McGuire contest the idea that members of political institutions are distinct from social movement activists. A more blurry line of activism defines the nature of participation by "institutional activists." These actors "straddle the institutional/non-institutional boundary," in that they “occupy formal statuses within the 
government” and "pursue movement goals through conventional bureaucratic channels (Santoro and McGuire 1997:504).”

In the case of the CCA, Diamond (1995) supports the observation in this study that drawing fine lines between grassroots mobilization and elite actors, both political and business, does not capture the nature of that SMO. She notes that, "Southern politicians and business elites largely facilitated the mobilization of what was also a veritable mass movement,” and that, “relations between the Citizens’ Councils and the southern political establishment were mutually beneficial (Diamond 1995:67).” The CCA, along with its southern regional local branches, “...functioned essentially as agents of a racist southern state apparatus” (Diamond 1995:75). However, this intimate relationship between local Councils and elites perhaps led to the demise of the segregationist movement writ large (Diamond 1995:67).

2.4 Not a Structural Analysis: Culture beyond Institutionalized Politics

Structural perspectives on mobilization, or political process models, have come to dominate the scholarship since the 1970s. In particular, resource mobilization theorists (the availability or not of resources), and political opportunity theorists (the favorability or not of shifting political dynamics), have focused their energies on understanding how structural factors shape the conditions for movement successes and failures. Resource mobilization originated as a reaction to classical era perspectives which tended to view collective protest as manifestations of social disorganization, mass hysteria and irrational expressions of mob anarchy. Instead, resource mobilization re-conceptualized activists as rational actors engaged in strategically planned episodes of protest (Morris 2000:445-446). Political opportunity theorists try to show the relationship between protest politics external to mainstream political institutions and that which occurs within the established conventional political structure. The basic premise of political opportunity theory is that, 
...exogenous factors enhance or inhibit prospects for mobilization, for particular sorts of claims to be advanced rather than others, for particular strategies of influence to be exercised, and for movements to affect mainstream institutional politics and policy” (Meyer \& Minkoff 2004:1457-1458).

As a criticism, it has been noted that structural dynamics are not the only significant factor in social movement mobilization. Culture, beyond institutionalized politics, is a motivation for collective action especially when faced with fierce opposition. In their bias toward structural factors, resource mobilization theorists, for example, have tended not to see culture as a significant factor but instead emphasize the accessibility of resources critical to a movement's success. Political opportunity theorists however, generally see culture as important, but similar to resource mobilizations theorists, do not view culture as critical in determining outcomes of social movements. While recent developments in cultural approaches have emphasized shared meanings between activists as critical in sustaining movements, which political process theorists acknowledge, they still downplay its role where agency is concerned, limiting its significance to “movement dynamics rather than as independent triggers of collective action” (Morris 2000:447). Changes in the political structure can offer advantageous situations for social movements to capitalize on, but culture also plays a role in shaping interpretations of ongoing events (Williams 2002:206-207).

Where grievances in social movements are concerned, resource mobilization theorists also ignore this important element. While it is true that grievances by themselves are not enough to effect change, they can be as important a factor in the accessibility or not of resources. In fact, as one scholar observes, "the social construction of grievances may be the critical step which allows members of socially dispersed groups to begin to mobilize for action” (Buechler 1993:222). Additionally, and more critical to this study, resource mobilization theorists fail to acknowledge the importance of ideology, and marginalize it, “...by equating ideology with the 
expression of grievances, and then dismissing both as constant background factors with little explanatory relevance” (Buechler 1993:222).

Structural approaches have also neglected the significance of emotion. Although, classical theorists like Max Weber, Herbert Blumer, Eric Hoffer and Karl Marx had helped to propagate the idea that rational action and emotional behavior are mutually exclusive phenomena, later social scientists from the political process models have developed deeply embedded “dismissive tendencies” toward emotion in social action (Goodwin, et. al. 2001:2-3). The conceptual limits of both resource mobilization and political opportunity theory is rooted in their strengths as scientifically rigorous approaches that place emphasis on structural factors while steering away from the messiness of emotionalism. As Goodwin, et. al. explain, ...the motivation to engage in protest - a process overflowing with emotionshas been largely ignored in recent research because it has so often been taken for granted under the structuralist assumption of objectively given interests. Once the desire and willingness to protest are assumed, only changes in the opportunity or the collective capacity to act on them are needed to explain the rise of social movements (Goodwin, et. al. 2001:7).

Cultural approaches such as frame analysis have helped to show that shifting dynamics in the political structure are not enough to explain the motivations of movement participants, but that collective action can occur and must be sustained through a common sense of group loyalty through the continual process of framing (Morris 2000). Following the theoretical foundations of the frame analytic perspective laid down by Goffman (1974), Snow, Rochford, Jr., Worden and Benford (1986), began to articulate what became the conceptual bridge between social psychological insights and resource mobilization perspectives on movement participation. The field was still in the process of addressing the problem of understanding exactly how SMOs maintain support for and participation in social movement activities. Many movement scholars had begun to consider "social psychological and structural/organizational factors" that give rise to and perpetuate movements. Unconvinced that a strong link had been drawn between 
psychological and structural/organizational factors, Snow and others (1986), attempted to provide both conceptual and empirical work linking the two perspectives by explaining what has now come to be known in the field as the 'frame alignment' process (Snow et al. 1986).

According to Snow and others (1986), earlier perspectives on movement participation ignored how grievances as a process were interpreted. They also portrayed a rather static characterization of movement participation; and tended to engage in overly broad generalizations of mobilization processes. Prior scholarship in the psycho-functional and resource mobilization perspectives had largely ignored how movement participants interpret or frame their grievances. Resource mobilization theorists in particular, Jenkins and Perrow (1977:250-51, 266), McCarthy and Zald (1977:1214-15), and Oberschall (1973:133-34, 194-95), too often treated what are in fact complex dynamic interpretive processes as static and uniformly occurring phenomena. These earlier approaches either missed or ignored the wide, uneven nature of the subjective condition of meaning that people bring to bear on the complex events around them. The ideological filters through which events are interpreted and given meaning by movement participants was therefore largely left unanalyzed. There were some scholars that had at least alluded to the sort of analysis missing in earlier social movement perspectives, including Piven and Cloward (1977:12), McAdam (1982), and Gamson et al. (1982), but further empirical inquiry was needed in order to support these earlier tentative insights (Snow et al.1986:466).

Since emotions are a dynamic set of experiences, consciounesses, attitudes and meanings, they must be harnessed and 'framed' in ways which speak to the perceived realities of movement participants. However, even the 'cultural turn' toward frames and related concepts fail to acknowledge that identity does not just arise out of cognitive faculties but is embedded in emotional sensibilities, sometimes deep and sometimes ephemeral. Emotions are socially rooted phenomena and are not detached from even the most rationally motivated movement participant. For the activist, protest can be a way to and through emotional self-discovery, and emotions can 
be taken advantage of in strategic ways. For protest movements, emotions can be and often are, constructed in ways that resonate with what people learn to be afraid of, and therefore concerned with avoiding, confronting, eradicating or containing (Goodwin, et. al. 2001:9).

\subsection{The Broader Contentious Politics of the CCA}

As previously discussed, protest movements do not operate in isolation, often inspiring counter-movements in response, and cannot be fully understood without being situated in the larger socio-historical context in which they take shape. Collective protest occurs in a broader field of 'contentious politics’ (McAdam 1982; McAdam, et. al. 2001; Tarrow 2011; Tilly 1978). In the context of contentious politics, according to Tarrow,

Organizers exploit political opportunities, respond to threats, create collective identities, and bring people together to mobilize them against more powerful opponents. Much of the history of movement/state interaction can be read as a duet of strategy and counterstrategy between movement activists and power holders (Tarrow 2011:8).

Contentious collective action is characterized by ordinary people mobilizing themselves around a goal or set of common goals to confront “opponents, elites, or authorities.” Participants in collective action Tarrow writes, "have power because they challenge the power holders, produce solidarities, and have meaning to particular population groups, situations, and national cultures (Tarrow 2011:8).” Rooted in contentious politics, protest movements function as the primary and frequently, only viable option for action available to ordinary individuals to challenge more powerful rivals. Collective action reaches the level of contention, "When it is used by people who lack regular access to representative institutions, who act in the name of new or unaccepted claims, and who behave in ways that fundamentally challenge others or authorities (Tarrow 2011:7).”

The problem with Tarrow's conception however, is that it limits our understanding of protest movements to those that emerge from below, or from the margins of society, or outside 
the established order and relatively disconnected from established political institutions. As

addressed earlier, such a narrow characterization of protest movements does not account for those that emerge from positions of relative power, or those that seek not to challenge the social order, but instead are interested in preserving the status quo and keep power in the hands of the privileged and away from those who seek to share it. Conservative right-wing protest movements like the CCA are those that generally possess “regular access to representative institutions” and, when relatively privileged members of society perceive their status is under threat this can lead to conservative collective action (McVeigh 1999 \& 2009). ${ }^{1}$

In consideration of Tarrow's larger discussion of contentious politics however, a question can be developed that is useful to the nature of this study. What happens when a protest movement intersects with "a cycle of reform begun at the top [that] trigger[s] a spiral of opportunities and threats (Tarrow2011:159),” and has geopolitical ramifications? Like the black freedom movement of the post-WWII era, the CCA was part of such a movement and it must be situated in the 'contentious' Cold War geopolitics of that period in order to fully understand the dynamics which produced it.

\footnotetext{
${ }^{1}$ As an additional criticism of the term 'contentious politics,' politics is inherently defined by contention, and therefore 'contentious politics' seems to be a redundancy that does not accurately describe instances where individuals act in a concerted manner to protest some identified source of angst in society. I do not take issue with the following definition:

...episodic, public, collective interaction among makers of claims under objects when (a) at least one government as a claimant, an object of claims, or a party to the claims and (b) the claims would, if realized, affect the interests of at least one of the claimants (McAdam, Tarrow and Tilly 2001:5).
}

However, such a definition can be applied to a more precise term like 'collective protest,' rather than 'contentious politics' since contentious politics is the very nature of modern society, especially within and between established political institutions. When are political institutions without contention? Established democratic political processes in the modern era are inherently contentious. "The origins of the social movement are thus intertwined with the rise of modernity itself” (Buecher 2011:1). 


\section{A 'MASSIVE' OVERSIGHT BY SOCIAL MOVEMENT SCHOLARS}

\subsection{Civil Rights and Segregationist Mobilization in Cold War Context}

To understand the dynamics that shaped the movement for civil rights of the latter half of the twentieth century in the U.S., the larger geopolitics of the Cold War must be considered. Indeed, as historical scholars have observed, the story of civil rights can no longer be told from an exclusively domestic perspective. There are direct linkages between the geopolitics of the Cold War and race relations at home in America (Anderson 2003; Borstlemann 2001; Dudziak 2000; Eschen 1997; Gerstle 2001; Layton 2000; Plummer 1996 and 2003). Unlike historians, social movement researchers have largely ignored the important Cold War context in which the civil rights struggle unfolded. More relevant to research on the CCA, sociological scholars have largely ignored the Cold War geopolitics of the segregationist counter-movement.

To date, Skrentny (1998), analyzing the Cold War era concerns of the U.S. federal government over civil rights issues, and Diamond (1995), focusing on conservative right-wing anti-Communism's impact on American political culture, remain the only social movement scholars to have fully grappled with the Cold War-civil rights/segregationist dynamic. Skrentny writes, “the conflict between America’s professed ideals of democracy and domestic racism was a problem because it dealt a serious blow to American moral legitimacy in the world (Skrentny 1998:240).” For the United States, addressing the problem of race in the domestic political structure helped to strengthen credibility in the international arena of Cold War geopolitics. In Diamond’s study she explains that elite anti-Communism was aimed at “...preserving economic inequality,” and was “...the libertarian strain in right wing thinking,” whereas in terms of mass mobilization, “....anticommunism was about obedience to authority and repression of domestic political dissent and deviant tendencies in the broader culture” (Diamond 1995:9).

McAdam (1982) is perhaps the earliest and most consistently published social movement scholar to acknowledge, but not do an exclusive study on, the Cold War-civil rights connection, 
including the significance of southern white counter mobilization. More recently, McAdam and Kloos (2014), in their examination of racial politics and social movements in postwar America, make the following observation about collective white resistance efforts.

Given its intensity at the time and, more important, its significant long-term political and electoral consequences, it is remarkable to us that this movement is largely forgotten today and certainly not invoked as an important factor by those seeking to understand the political economy of the contemporary United States (McAdam and Kloos 2014:104).

In addition, they assert that,

What analysts have almost entirely missed, however, is the extent to which the southern segregationist countermovement morphed into and inspired the more generalized nationwide "white backlash” of the mid-to-late 1960s” (McAdam and Kloos 2014:105).

While McAdam (1982) acknowledges the significance of the post-WWII era of black protest and southern white counter protest, Skrentny (1998) has criticized McAdam for spending a mere two paragraphs discussing the Cold War-civil rights relationship (Skrentny 1998:238). While Skrentny does acknowledge that for the United States, addressing the problem of race in the domestic political structure helped to strengthen credibility in the international arena, for southern regional actors however, there was little interest in the international ramifications of the civil rights agenda. He writes that,

Local audiences in the Deep South States tended not to be concerned with world opinion or with equal-rights issues, and thus the standards of legitimacy were very different for leaders in states such as Alabama and Mississippi than they were for White House occupants (Skrentny 1998:243).

But the historical record suggests that southern regional actors were very much concerned with “world opinion” and “equal-rights issues.” In fact, they acted upon a different interpretation of what was at stake in the midst of America's effort to contain the spread of Soviet Communism not only abroad, but within the social and political fabric of American life. Southern 
segregationists who mobilized themselves in a massive resistance effort (Bartley 1969; Lewis 2004; Ward 2011; Woods 2004), against civil rights reforms, concerned themselves with the politics of anti-Communism by embracing the 'counter-subversive master frame’ (Noakes 2005), to brand the entire southern civil rights movement as an orchestration of Soviet Communism.

\subsection{Segregationist Cold War Geopolitics}

Indeed, Cold War anti-Communism gave an international aspect to southern regional segregationist politics. Black protest in the American South, according to segregationists, was evidence of the reach of Communist penetration from within, ever working to unseat the white man from his rightful place as steward of civilization. From the perspective of segregationists, the inevitable tragic outcome of desegregation and erosion of the white power structure in the South can be seen in the presumed numerous examples of disorder and savagery in the process of African independence and liberation from white colonial rule. If Americans had any doubts about the wisdom of maintaining the Jim Crow status quo, one had only to look overseas to witness the 'Negro' in his ‘true natural habitat' exhibiting the ‘inherent qualities of primitivism', unloosed from the civilizing restraint of white power. The nature of the Negro, segregationists believed, is such that self-government is not possible. Law and order can only be imposed on the Negro so as to restrain the natural inclination toward barbarism (Noer 2003).

Segregationists therefore expressed great admiration for the system of white rule in South Africa, and used the ‘chaos’ of revolution among anti-colonial movements in other parts of Africa as the logical conclusion of desegregation: the collapse of civilization itself. Such an interpretation of black anti-colonialism is ironic given the anti-colonial origins of the United States. The significant difference for the African independence movements however, according to segregationist thought, was that Negroes can only be the authors of chaos and never civil order. The unruly passion of black revolt would never subside if given the chance to continue unabated. Therefore, the civilizing influence of white rule was a vital necessity for the preservation of all 
humanity, especially in the context of the global struggle against the corrupting influence of Communism (Noer 2003).

Another component of the segregationist interpretation of global affairs was the idea that U.S. foreign aid was an instrument of Communist subversion; that it was anti-white and unAmerican in its orientation as evidenced by U.S. financial assistance through the United Nations for Third World independence movements against white colonial rule. According to segregationists, America was too apologetic in its foreign-policy orientation particularly in light of international critiques of U.S. domestic race relations. The American government, segregationists contended, was financing the collapse of white civilization, thus instigating its own demise without recognizing the true threat of Communist subversion that operated in the disguise of seemingly genuine black protest. The pretense of U.S. aid for oppressed peoples of the Third World was at its core, as segregationists saw it, a Communist plot to destabilize global white protestant American-style democracy (Noer 2003).

\subsection{Segregationist Anti-Communism in America}

In the wake of the United States Supreme Court decision in Brown (1954), southern segregationists attempted to take advantage of America's preoccupation with Communism to advance efforts at eradicating civil rights organizations like the NAACP. Legislative and administrative agencies were established in almost all of the former Confederate states, Alabama, Arkansas, Florida, Georgia, Louisiana, Mississippi, North Carolina, South Carolina, Texas and Virginia, in order to preserve the southern white power structure. For a time, the politics of antiCommunism proved quite useful among a host of tactics used to discredit black protest and defend the southern racial order. Through the politics of anti-Communism southern segregationists portrayed civil rights organizations as un-American agents of foreign subversion (Bartley 1969; Bloom 1987; Braukman 2012; Egerton 1994; Horne 1986; Katagiri 2001; Lewis 2004; Record 1964; Schrecker 1994 and 1998; Ward 2011; Whitfield 1996; Woods 2004). While 
southern segregationist anti-Communism took the form of various southern state legislative investigation agencies, these institutions maintained a relationship (not without friction), with more self-styled grassroots movements. Southern local and regional organizations such as the Citizens' Councils must be understood in the longer history out of which they emerged in the post-War era (Lewis 2004; Woods 2004).

The white South's concern with racial security and southern fears of subversion in an otherwise 'harmonious' racially based social order must be attributed to the deep and intense historical tradition of southern Confederate nationalism, stretching back to the period of plantation slavery (Woods 2004). During the rise of America's abolitionist movement southern proponents of black enslavement often characterized abolitionism in ways that resembled the politics of xenophobia. Though not limited to southern culture, southern whites had come to understand themselves as naturally superior and that blacks being innately inferior, were therefore dependent upon whites in a complex civilized society. Black liberation was therefore perceived as an abomination; an impulse that blacks themselves could not ultimately be held responsible for. Those unaccustomed to the southern way of life, often referred to by indigenous white southerners as “outside agitators” and "Yankee intruders,” were thought to be the true culprits, the real instigators of black militancy and threats to the presumed natural order of things. Therefore, the fear of radical change to the southern social order and to the racial status quo, the fear of losing power and control over the southern black population during the post-Second World War civil rights era, was an extension of a much older historical tradition of southern white supremacist nationalism (Lewis 2004; Ward 2011; Woods 2004).

The intersection between traditional white supremacist ideology and Cold War era geopolitics produced segregationist anti-Communism. Though it was a major defining characteristic, it did not represent the full scope of the post-World War II conservative right-wing effort. As noted earlier, historians understand this period of intense conservative right-wing 
political action and grassroots activism as 'massive resistance' (Bartley 1969; Day 2014; Lewis 2004 \& 2006; McMillen 1971; Parkinson 2004; Wallace 2013; Ward 2011; Webb 2005; Wilhoit 1973). The next section provides a detailed discussion of the historiography on that subject. It first briefly addresses historians' understanding of it as a movement that perhaps does not conform to strict conceptualizations by social movement researchers. Next it defines what massive resistance was and then situates it in a longer historical context of white southern obstinacy. The discussion then turns to the significance of the year 1954 as a generally agreed upon chronological starting point, followed by a detailed account of both the institutionalized political elite and grassroots aspects. Finally, the ideology of massive resistance is addressed as the focus of this research.

\section{MASSIVE RESISTANCE AND THE ERA OF SEGREGATIONIST PROTEST}

\subsection{Historiography on Massive Resistance}

Scholarship on massive resistance dates back at least to the early 1970s (Webb 2005), and this section aims to detail its historiography and make the case for social movement scholars to begin to recognize the significance of the post-World War II era of conservative right-wing collective action. Historian's understanding of the segregationist movement includes grass-roots organizations and state governmental institutions as integral components of southern white opposition to civil rights activism and federal civil rights reforms. The historical scholarship does not appear to distinguish between grassroots activism and the political establishment on the question of how to appropriately conceptualize a social movement. To draw a fine line between what social movement researchers understand as grassroots collective action, and the 'contentious politics’ (McAdam, et. al. 2001:5), of elite political institutions, may distract from the complexities of how historians have come to understand massive resistance. Indeed, there was much overlap between the contributions of the political establishment and that of the grassroots to what became a broad-based southern white resistance effort. 


\subsection{What Was Massive Resistance?}

Massive resistance has generally been understood as an organized effort on the part of the South to defend white supremacy and was a major obstacle to the civil rights movement (Webb 2005). It was defined essentially by white southern intransigence, both institutional and grassroots. It was organized hostility to black liberation; a conservative reflexive response to progressive change to the South's social fabric woven together by the many threads of the racial hierarchy. Geographically, while it is true that segregation was not confined to the South, and that white supremacist social dynamics were in fact national in scope and in history, there was indeed something unique in the southern white reaction to federal civil rights reforms in the post-World War II era (Bartley 1969). To be sure, it has been noted that, "only the eleven states of the former Confederacy enacted legislation to prevent or hamper enforcement of the 1954 school desegregation decision” (Bartley 1969:x). However, white reaction to Brown was most virulent in the Deep South, while the Upper South states embraced a more realistic attitude of sober resolve (Bartley 1969:81).

Massive resistance should also be understood as a collaborative effort between the segregationist political establishment throughout and among southern states and self-identified grassroots segregationist organizations. The carefully calculated intransigence by southern white political elites both shaped and was influenced by the diverse strategies of grassroots activist protest (Woods 2004). Massive resistance leadership took the form of political elites, grassroots organizational leaders, and prominent community activists of various sorts. These three leadership types were not mutually exclusive and indeed many individuals retained multiple positions in the political establishment, regional organizations and within local communities (Wallace 2013:15).

While both elite and grassroots segregationists collaborated in their strategies of resistance, like the movement for civil rights, internecine conflict was a feature of segregationist 
dynamics. Anxieties over violence by more militant groups led Mississippi elites to embrace a more "accommodationist" approach to their segregationist agenda, finding strategic moments of opportunity to make concessions to the integrationist opposition. In this way then, massive resistance was not politically monolithic. Southern whites selectively adopted a strategy of tokenism where it was perceived to facilitate the politics of moderation, at least publicly. More repressive forms of segregationist actions were accomplished in other subtle ways that hampered the cutting edge of the civil rights revolution (Crespino 2011:11-12).

Historians have also emphasized that massive resistance must be understood in term of its ideology; as a mobilization of the white supremacist rhetorical tradition in an effort to defend the white power structure as manifest in the South’s racial segregation system (Lewis 2004; McMillen 1971; Wilhoit 1973; Woods 2004). Participants in the segregationist effort saw themselves as champions of democracy and of liberty by maintaining "racial integrity” and "racial harmony,” and by remaining steadfast in the defense of the "southern way of life." Ideologically, Massive Resistance was rooted in the logic of states’ rights, decentralization, and constitutional government as particularly related to local control of southern race relations. It was an expression of white southern Confederate nationalism (Woods 2004).

\subsection{The Dixiecrat Revolt as a Precursor to Massive Resistance}

Although historical scholarship generally treats the Supreme Court ruling in Brown (1954) as the chronological starting point, some historians argue that the South’s segregationist era of protest was fully mature prior to that monumental Court decision and that the post-1954 period represents a dramatic increase in segregationist activism (Fredrickson 2001; Ward 2011). Segregationist intransigence began as early as the start of the Second World War, and was certainly not an out-of-nowhere reactionary, impulsive, southern white reflexive response to an unforeseen challenge to the racial status quo, but instead was a highly coordinated, and sophisticated product of a white conservative entrenchment campaign established decades earlier 
(Ward 2011). To underline its historical significance in white southern obstinacy, it has been asserted that the Dixiecrat revolt was “...the most notorious manifestation of the pre-Brown backlash” (Klarman 1994:86).

The year 1948 produced perhaps the most intense expression of southern white political antagonism when insurgent southern Democrats broke ranks with their party to create the States' Rights Democratic Party, also known as the Dixiecrats, with Strom Thurmond as the party’s presidential candidate. The Dixiecrat revolt was not for mere symbolism but aimed to defeat Harry Truman in that year's presidential election. Although they failed in this effort, the insurgency proved to be profoundly significant for the future of the South's political culture, and even the nation (Fredrickson 2001). The Dixiecrat revolt was the product of intraparty factionalism and southern white regional anxieties over growing federal power (Mckee 2008), especially with regard to civil rights policies including anti-lynching, anti-poll tax legislation and the desegregation of interstate transportation facilities (Pleasants 1998). The alienation of racial conservatives by postwar civil rights reforms produced political realignments that signaled the coming transformation of the American political system along the lines of civil rights reforms (Gelbman and Rhodes 2011), where growing displeasure with federal government reach into local economic issues and race relations led to the emergence of "a pan-southern white unity" (Feldman 2009:200).

The Dixiecrat political insurgency laid the groundwork for later white southern resistance movements, particularly Massive Resistance. Parallels between the two can be observed in the ideology of the Dixiecrats who emphasized individual liberty through local government, southern traditional respect for the racial superiority of whites and the inferiority of blacks, opposition to the progressive racial ideology of equality for the Negro and recognition of an anti-South political agenda in the perceived federal government effort to erode southern white rule (Lemmon 1951:164-165). Jeffersonian ideas about limited government and restraint on federal power, as 
articulated in the Kentucky Resolutions, became the intellectual thrust of the movement. The State’s Rights Democrats, as they were officially named, often referred to themselves as “Jeffersonian Democrats” (Parkinson 2004:7).

The Second World War saw the movement of white supremacist ideology from the margins to the forefront of politics in the South. Arguments in favor of white supremacy evolved as the nation disengaged from war overseas and was reoriented toward more domestic concerns. New Deal federal programs were regarded as a threat to southern regional hegemony (Ward 2011:89). Conservative agricultural and industrial elites aimed their ire particularly at the Fair Employment Practices Commission (FEPC), which outlawed racial, religious and nationality discrimination. From the perspective of the Dixiecrats, the FEPC infringed upon the constitutional rights of employers to hire and fire as they saw fit. The newly instituted federal racial quota regime, as Dixiecrats understood it, was a violation of states' rights and local control. From this point of view, federal government civil rights reforms in labor relations signaled the rise of undemocratic forces in America (Fredrickson 2001:6-7).

Indeed, as most historical scholars appear to agree, the Dixiecrat revolt of 1948 grew out of Truman's embrace of a civil rights agenda, the realignment of large voting blocs of northern blacks with the Democratic Party away from the Republicans, and the increasing influence in national politics of labor power in major urban areas (Lemmon 1951). Though the Dixiecrats, in their initial form, strategically avoided a complete exit from the Democrats and instead embraced a more "traditional" face of the party (Parkinson 2004), they initiated the eventual abandonment of the Democrats because of their racial liberalism, siphoning off its conservative rank-and-file, and began to embrace the Republican Party (Olson 2008). Though the insurgency ultimately failed to sustain itself as a political institution, its anti-New Deal and civil rights reform opposition signaled an important new direction in the South's political culture. The Dixiecrat revolt, like Massive Resistance was regional in scope and defined by local dynamics, while being 
fully concerned with domestic and international political currents. Although the movement did not last beyond the late 1940s, the states’ rights segregationist agenda became central to post1954 southern white obstinacy (Fredrickson 2001:9-10). These earlier voices of southern white opposition to civil rights developed the rhetorical infrastructure for later segregationist activism (Ward 2011).

It has been argued that the Dixiecrat insurgency cannot be accurately characterized as merely a reaction to racial reform policies but was also a response to discontent with federal government confiscation of tidelands oil following the Supreme Court's 1947 ruling on the matter (Klarman 1994). Although organized southern white intransigence did indeed predate Brown, one historian warns that scholars "must not lose sight of the relatively limited scope of that resistance, especially when compared with a tidal wave of hysteria that swept the South after the Brown decision” (Klarman 1994:92). On the matter of a recognizable pre-Brown white southern insurgency,

...neither the Dixiecrat Revolt of 1948, the 1950 Democratic senatorial primary defeats of Frank Graham and Claude Pepper, nor the sundry other race-baiting political campaigns of the early postwar era demonstrate the existence of the powerful southern racial backlash prior to Brown. While southern defense of the racial status quo was unquestionably beginning to stiffen, the politics of the late 1940s and early 1950s bore little resemblance to the racial fanaticism which followed Brown (Klarman 1994:97).

\subsection{4 and the Rise of Massive Resistance}

Despite the acknowledged significance of the Dixiecrats of 1948 and other prior white insurgency movements, most historical scholars point to 1954 as the starting point for massive resistance following the Supreme Court's Brown decision. Although it was limited to striking down segregation in public education, many on both sides of the issue regarded the ruling as one that would open the door to litigation against racial segregation in many other aspects of American life. In a second decision to desegregate public schools, Brown II, the Supreme Court emphasized implementation "with all deliberate speed," though it did not specify a date by which 
integration had to be fully complied with. The NAACP then organized a legal effort for the unambiguous enforcement of the ruling, which then prompted the most energized and broadbased mobilization of southern white opposition. Reaction to the Court's decree by segregationists was swift, widespread and diverse. The thrust of massive resistance was the interpretation of Brown as federal government overreach, the product of foreign conspiratorial influence and the reigniting of sectional conflict reminiscent of the Civil War era (Webb 2005).

Although Deep South opposition to the Supreme Court decision was virtually instantaneous, many embracing the Mississippi State Supreme Court’s Judge Tom P. Brady’s term to describe the decision as "Black Monday," white southerners did not speak with one voice in their objection, as evident in the electoral tension between unapologetic segregationist politicians and those who took a relatively moderate position on the question of integration. While many parts of the Deep South responded with vehement and militant resistance, other regions, especially the Upper South, varied from reluctant acceptance to enthusiastic approval. Indeed, there were segments of the South where no apparent social and political unrest developed in reaction to the implementation of Brown. The Upper South did not embrace the neoConfederate radicalism of the Deep South, but instead represented a hesitant "moderate” stance of acquiescence to the decision (Webb 2005). The initial white southern response to Brown was not characterized by reactionary radicalism, but instead was more somber acquiescence. There are even accounts of praise for the decision. However, although there was unity in its denunciation among southern representatives and senators in Washington D.C., the constant bombardment of wholehearted endorsement for Brown from the national and international media into southern white homes may have contributed to the sense of isolation, and attack, which nurtured a kind of southern nationalistic xenophobia that became integral to the ideology of massive resistance (Wilhoit 1973). 
In the Upper South, where state governors functioned not as mere figureheads but as consequential leaders to which southern whites often referred in formulating opinion on major issues of the day, reactions to Brown varied but were generally more measured than their Deep South counterparts. Southern state legislative bodies offered up their reactions to Brown somewhat later than state governors because of the calendar of legislative sessions. Louisiana was the exception however, with the introduction of a resolution to censure the Supreme Court for apparently overstepping its constitutional authority by violating the right of states to determine their own local affairs. Three proposed bills aimed at the preservation of racial separation became law within a month of the ruling, signaling the start of the legislative agenda of massive resistance. The Alabama and Mississippi legislatures flirted with the idea of shutting down the public school system to resist integration and provide financial assistance for white students to attend private schools. Other southern states explored various legal options for circumventing the Court's implementation decree. On the whole, initial reactions to Brown were largely limited to legal maneuvering in southern state legislatures and did not explode into all out rebellion (Wilhoit 1973:34-35).

In terms of private reactions, southern newspapers in the immediate aftermath of Brown were measured in tone, but the Deep South editorial response was indeed ferocious. Many other editors initially remained silent on the matter or focused instead on the presumed futility of instituting such a decree, given the expected intense hostility (Wilhoit1973:37). The South’s major denominational bodies praised the decision as being in line with Christian theology. Local congregational bodies, however, especially among the rank-and-file, differed from the elites. On the whole, in the initial period after Brown, the South's religious institutions, like the public sphere, produced a diversity of opinion ranging from wholehearted agreement, to reluctant acceptance, to vehement disapproval, but again, it was in the Deep South where the temperature of discontent was the most heated (Wilhoit1973:39-40). 


\subsection{Massive Resistance and Elite Institutional Opposition}

Massive resistance, as an act of defiance beyond the rhetoric of the Southern Manifesto first began to materialize in the fall of 1954 when local school districts facing desegregation were met with local demonstrations, including violent protest, and outright refusal to cooperate, on the part of local and state political leaders. The movement against civil rights perhaps took its most decisive form through southern state legislative maneuvers that instituted hundreds of laws aimed at obstruction. Southern state governments particularly focused their repressive political effort on the NAACP and its campaign for full implementation of the Brown decision. Various NAACP branches throughout the South were burdened with southern state pressures to divulge membership lists for the publicly stated purpose of uncovering Communist ties, but essentially to subject the organization's members to intimidation and potential violence. As one scholar notes, "By 1958 the NAACP had lost 246 branches in the South, and its litigation strategy was in disarray” (Webb 2005:6). Though the southern political establishment often couched its efforts against civil rights as existing within the limits of constitutional authority, their actions created the social conditions for, and gave tacit approval to, a culture of violent militant extremism (Webb 2005).

The legislative strategy of massive resistance included the Southern Manifesto, the doctrine of nullification and interposition guided by the philosophical constitutional logic of states’ rights federalism, hundreds of laws passed in the South aimed at complicating school desegregation efforts, and the suppression of anti-segregationist political dissent. Southern courts were employed in the judicial effort against integration. The southern criminal justice system not only turned a blind eye to white supremacist terrorism, but indeed functioned as part of the institutionalized structure of state sanctioned terrorism. Economic reprisals, state-sanctioned violence and political repression all constructed the artifice of a segregationist police state (Wallace 2013:19-22). 


\subsection{Massive Resistance and Grassroots Organizations}

Earlier scholarship on massive resistance may have focused too heavily on elite institutional opposition. As one early historian on the subject asserts, "state action more than private action" drove the engine of white opposition where "the people of the South followed more often than led" (Wilhoit 1973:48). This view is in direct contrast with a more recent scholar who seeks to avoid the shortcomings of a top-down analysis that only emphasizes the elite perspective and instead attempts to give voice to local grassroots activists (Lewis 2004). In any case, massive resistance materialized in the form of a great many segregationist organizations across the South, but the Citizens' Councils, as noted earlier, represented the vanguard rank-andfile of the movement (Bartley 1969), and was the most organized, widespread and politically influential of segregationist organizations (McMillen 1971).

Citizens' Councils proliferated throughout the South after Brown, and became a force to be reckoned with in many regions of the southern political landscape (Day 2014:11). The Council thrived on the passions of fear, outrage and hatred in the heart of the Deep South (Bartley 1997:83), and was most potent in Mississippi, Alabama and Louisiana (Ward 2011:160). The organization positioned itself ostensibly as a legitimate effort to prevent the erosion of the segregationist social order; in contrast to the more extreme violence and the lawlessness of organizations like the Ku Klux Klan (Webb 2005:4).

Although the Citizens' Council styled itself as a respectable law-abiding organization that was merely an expression of middle-class southern white values, it nevertheless engaged in more covert forms of economic and political intimidation and was intimately involved in state sanctioned violence as a means to achieve its white supremacist aims (Day 2014:11). The Council specifically engaged in tactics of voter suppression of African-Americans, termination of employment of civil rights activists white or black, denial of bank loans and credit, and a host of other activities aimed at crushing civil rights activism (Webb 2005:4). 
According to Wilhoit (1973), the Citizens' Council never developed into a grass-roots movement in terms of rank and file membership. Members of the Council were intimately involved in pro-segregationist legislation during the height of the massive resistance counterrevolution (113-114). Ward (2011) also seems to suggest that the Citizens' Council was not as much a grass-roots organization as it was a political instrument of southern white business and political elites (160). This is in direct contradiction to Bartley (1969), who states that, "in Mississippi, as in several other southern states, the Council represented a genuine grassroots movement (85). Despite Bartley’s difference of perspective on how to properly categorize the Citizens' Council, he does provide a considerably detailed account of the myriad segregationist organizations which thrived following the Brown decision. In discussing each southern state's Councils in terms of size, political power and influence, Bartley makes the point that the Mississippi Citizens’ Council represented the geographic ground zero of Deep South resistance (89).

Alabama followed closely behind Mississippi with its formation of the American States' Rights Association out of Birmingham, which laid the foundation for the Alabama Citizens' Council. Alabama business elites were primarily responsible for spearheading the creation of segregationist organizations in that state, and had less success than in Mississippi in maintaining support from political elites. After the organization's initial slow growth in the state, late 1955 saw the birth of the Central Alabama Citizens' Council, which functioned as the core of the wider Council movement in that state. With the onset of the bus boycott in Montgomery, that city became a magnet for Council membership and activism, and the organization's headquarters was established there, which was later relocated to Selma in 1958. The industrial suburbs of Birmingham also saw the expansion of Council activity (Bartley 1997:89). Mississippi and Alabama Citizens' Councils maintained an intimate relationship with state political elites which other Deep South states did not enjoy (Bartley 1997:93). 
Citizens' Councils in Louisiana grew out of the efforts of the Joint Legislative Committee, which also goes to the question of how "grassroots" the Council in Louisiana actually was. The politically embedded Louisiana Council resulted in what Bartley describes as "an interesting example of legislative coercion,” where it functioned more as a "top-down” organization than in Mississippi and Alabama. The Louisiana Council was also intimately involved with the American Association for the Preservation of State Government. While Councils in other nearby states began to decline, the Louisiana Council continued its expansion beyond 1956 (Bartley 1997:90-91). More broadly, Mississippi, Alabama, Louisiana, South Carolina, and Virginia (where the Defenders of State Sovereignty and Individual Liberties organizations were born), “contained the bulk of white supremacy organizational strength.” As Bartley makes clear, “Nowhere else did the movement achieve comparable membership or political power” (Bartley 1997:96).

Beyond the above named states, segregationist organizations sprouted in other regions of the South. The Patriots of North Carolina, Inc., formed in August 1955, but ultimately did not wield much political influence and exhibited little success in growing membership. It had one dramatic moment of noteworthy success, however, by helping to prevent the reelection of two out of the three South Carolina politicians who were not signatories of the Southern Manifesto. The Citizens’ Council did not have a significant presence in Texas, Florida, or Tennessee. Born in the summer of 1955, the Texas Citizens' Council focused on political pressure. November 1955 saw the creation of the Association of Citizens' Councils of Texas. The Texas Referendum Committee was involved in the collection of enough signatures to have a statewide vote to adopt a segregation proposal for the entire state, which were included in the platform of the state Democratic Party by July 1956. In early 1956 Florida gave birth to the Federation for Constitutional Government, which represented a more significant organizational force than the Citizens' Councils there. Although membership was relatively small, the Federation made its 
presence felt by keeping segregation on the forefront of political issues in Florida. Bartley regards the Tennessee segregationist movement as largely impotent. In that state there were several segregationist organizations including the Society to Maintain Segregation, the Citizens' Council, the White Citizens’ Council, the States' Rights Council, the Pro-Southerners, and the Tennessee Federation for Constitutional Government (Bartley 1997:96-99).

Political diversity is what perhaps prevented the Council from gaining a meaningful foothold in Arkansas and Georgia. In 1955 Pine Bluff, Arkansas produced an organization called White America, Incorporated. The Arkansas Division of the Citizens' Council of America formed by the fall of 1956, while the Capital Citizens’ Council formed in Little Rock, Arkansas.

Although membership was small, it became the “most active” and "of exceptional significance.” The Georgia States Rights Council (SRC) formed in Augusta in December 1954 and was a “relatively powerless local organization” until political leaders convened in Atlanta in September 1955 to give the SRC, together with the Commission on Education with the assistance of the state government, a more focused mission to defend segregation and promote the ideology of white supremacy. Atlanta became the nucleus of organizational activism, particularly the production of segregationist literature. This still did not however produce a successful Georgia Council movement. According to Bartley, the unimpressive segregationist movements in Arkansas and Georgia were related to local unstable political dynamics (Bartley 1997:100-102).

Emerging rather quickly as the vanguard premier segregationist organization, the Council, according to Bartley, was a genuine expression of white southern sensibilities on social norms and civic engagement in the tradition of Confederate nationalism. The Council phenomenon varied widely throughout the South as that organizations' success depended upon maintaining an uneasy alliance between middle and upper middle class suburbanites and the industrial working class. But the common shared interests centered on keeping the South free from the influence of racial egalitarianism. Fissures emerged however, over such issues as the 
extent to which Councils should embrace anti-Semitism, or whether violence should be adopted as a legitimate means of resisting segregation. Where the presumed respectability of the Council could not satisfy the more anti-Catholic, militant and clandestine of sensibilities, segregationists tended to ally themselves with the legendary Ku Klux Klan (Bartley 1997:105).

\subsection{The Ideology and Rhetoric of Massive Resistance}

According to John P. Jackson Jr. (2005) there were two major historical periods when white supremacist ideology was mobilized in defense of the South's racial hierarchy. The first was in the several decades leading up to and through the Civil War during the abolitionist movement's most ardent efforts against the plantation economy of the South. The second occurred in the aftermath of and as a direct reaction to Brown (1954), when southern segregationists organized the massive resistance counter-movement to the civil rights revolution. The complex cultural tradition of white supremacist ideology that developed in the American southern regional context found great inspiration and took on a new energy in the post-World War II era as segregationists marshaled their arsenal of argumentation against civil rights reforms and activism. While scholars have made significant contributions in their analysis of antebellum racist arguments in defense of the South's plantation economy they have largely ignored the explicit articulation of segregationist ideology from the era of massive resistance (Jackson 2005:5).

The movement-countermovement dynamic between civil rights activists and segregationists can be seen as a propaganda media contest as both sides invested a great amount of effort in crafting a favorable public image while attempting to portray the other in ways unfavorable to public opinion. What these opposing movements had in common was recognition that the battlefield was not merely limited to the geographic confines of the South, but that the eyes of the nation and even the world were watching as events unfolded. On the whole however, the segregationists did not receive the kind of favorable national media attention as civil rights 
activists, which produced even more intransigence on the part of the Massive Resistance movement. As segregationist defiance intensified, those southern white journalists or media outlets that either embraced civil rights or at least gave up the fight, seeing its futility, were subject to a concerted effort to stifle diversity of opinion (Wallace 2013:1-3). In this effort, hard core segregationists mobilized their white supremacist belief system.

The “counterrevolutionary” ideology of massive resistance, according to Wilhoit (1973), was rooted in a regional southern nationalism which served as the intellectual basis for racial separation. It promoted social cohesion and supplied the "propaganda ammunition for psychological and political warfare against revolutionary opponents” (56). Two myths functioned as its ideological pillars: white supremacy and the legal philosophy of states’ rights and, in Wilhoit's view, the most significant aspect of white supremacist mythology is its "verbalized propositions”, ten of which he assembled from documented rhetoric of segregationist literature and speech (58). Wilhoit's list includes: 1) the belief in fundamental racial differences between blacks and whites; 2) the denial of titles of respect for blacks given their inferiority; 3) the belief in white superiority as evidenced by the history of their civilization versus the barbarism of the black man; 4) a belief in the innate, immutable inferiority of blacks as created by God, and therefore the divine sanction of segregation; 5) the codification into law of racial categorizations in ways that clearly delineate the fact of racial difference as set forth by God in nature; 6 ) that black inferiority is a fact of nature, segregation should not be misunderstood as the product of racial bigotry or prejudice, but as natural; 7) the belief in racial segregation as a Christian and democratic tradition; 8) the belief that blacks themselves are aware of their own racial inferiority and therefore also understand that segregation is for the protection of their own best interests; 9) the belief that southern segregation has had the positive effect of keeping pure the Anglo-Saxon race, and that this racial purity is tied to the continuance of a strong American nation; and finally 10) the fundamental belief that the collapse of segregation would bring about the dilution of 
Anglo-Saxon blood because of the untamed sexual passions of the Negro, which would result in racial decline and the rise of savagery and mongrelism (59-61).

Perhaps an eleventh core segregationist belief was the deep-rooted traditional southern white fear of foreign intrusion to undermine the racial order, which took on the logic of a Cold War geopolitical imperative in the post-1954 era. However, it has been noted that antiCommunist politics was embraced by Dixiecrats in their opposition to New Deal federal policies prior to Brown, and perhaps even added strength to their cause (Fredrickson 2001:6-7). Where the post-1954 segregationist movement is concerned, the term massive resistance itself, as one scholar suggests, was created out of the language and logic of U.S. Cold War foreign-policy terminology (Lewis 2004:43). Segregationists were fully aware of the Cold War ramifications of Brown. Cold War national and global geopolitics resurrected and gave legitimacy to traditional southern white fears of "outsiders" conspiring to destroy their way of life (Lewis 2004).

Indeed, there is a growing scholarship on civil rights in Cold War context (Anderson 2003; Bloom 1987; Borstlemann 2001; Braukman 2012; Dudziak 2000; Egerton 1994; Gerstle 2001; Horne 1998; Lewis 2004 \& 2006; Lyton 2000; McMillen 1971; Plummer 1996 \& 2003; Schrecker 1994 \& 1998; Skrentny 1998; Von Eschen 1997; Whitfield 1996; Woods 2004). As Lewis (2004) advises however, not enough is attention is being paid to southern white sensitivities to Cold War issues as related to the South's racial order being used as a propaganda piece by international critics of the United States, especially Communists. Lewis is also critical of the elite bias given to studies of the South’s Cold War concerns. In his critique of historians, Lewis asserts that scholars have missed the “...ideological arguments and considerations that underpinned segregationist action, both at the grassroots and at the leadership level.” He argues that massive resistance is best understood as “...not simply an elite-driven movement but rather was the result of a complex interplay of language, tactics, and ideas between those elites and the grassroots” (30-32). For scholars of protest movements, the particular concern here is to make 
sense of the ideology which gives logic to the rhetoric activists and organizations rely on as reasons for collective protest.

\section{IDEOLOGY AND FRAMES IN SOCIAL MOVEMENT RESEARCH}

Previously employed as a conceptual tool elsewhere, and widely used in other fields today, the frame concept was first introduced into the discipline of sociology by Erving Goffman (1974), where it is understood as a cognitive template that organizes everyday experiences, sorts out the chaos of perceived reality and shapes interpretation of events (Johnston and Noakes 2005). Social movement researchers in particular have found great use for the frame concept in helping to understand how SMO’s engage in grievance construction as a means to mobilization. In the process of framing and in the construction of grievances, SMO’s rely on existing knowledge systems or ideologies. Social movement researchers have noted the importance of distinguishing SMO ideology from SMO frames. Ideology is the socially constructed dynamic system of knowledge which functions as an important variable in shaping the direction of movements (Snow and Bedford 2005). The process of framing on the other hand is the attempt to attach meaning or symbols to well-established ideologies that define a movement (Oliver and Johnston 2005). It is important to draw this distinction so that the concept of ideology and its centrality in social movement research is not trivialized by treating it as a mere frame of protest. The power of the frame concept is most clearly visible and useful to researchers when it is distinguished from the ideological context in which it is being used and deployed as an intellectual instrument for collective action (Oliver and Johnston: 2005:186).

If frames and ideologies are treated as synonymous, it has been noted, "we will lack the analytic tools, even the very language, for talking about [the] fascinating instance of the same frame being tied to diametrically opposed ideologies” (Oliver and Johnston: 2005:187). This point is especially relevant to the broader context in which to understand the subject of analysis in this research, where civil rights activists and southern segregationists functioned as oppositional 
movements, both drawing on the same anti-Communist frame of the early Cold War era, though operating from differing sets of ideologies: the ideology of civil rights (as specifically related to racial equality through the process of racial integration), versus the ideology of white supremacy (as related to a system of racial inequality and segregation based on the notion of white superiority). Though oriented toward different ideological interpretations of the meaning of citizenship and democracy in America, civic nationalism versus race nationalism (Gerstle2001), both movements used the anti-Communist frame as a way to mainstream their causes (Lewis 2005).

Another advantage in distinguishing ideologies from frames is the researcher's clearer perception of strategic agency exhibited by social movement actors. In this way, scholars can avoid reducing activists to mere reactionaries. This is particularly relevant in the case of conservative right-wing movements where researchers have traditionally overlooked how conservative right-wing activists operate in tactically rational ways as related to movement ideology (McVeigh 2009). Ascribing ideological motivation to movement participants recognizes their situational awareness as adherents to a movement's ideology and illustrates how ideological orientation comes about by way of socialization (Oliver and Johnston 2005).

While Snow and Bedford make the assertion that, "Framing, in contrast to ideology, is an empirically observable activity” (2005:210), Oliver and Johnston however, contend that both frames and ideologies are measurable and should be treated as empirically distinct. "In fact”, they write, "both frames on the one hand, and ideology on the other, can be observed in texts, public utterances, and interviews with leaders and activists; and both are in the same sense ultimately observable within an individual's mind" (2005:216). The position taken here is that both ideologies and frames as empirically observable social phenomena, and the two are treated as distinct. 
It has been noted that conservative right-wing SMO’s, like civil rights and other more liberal/progressive movements, rely upon grievance in constructing new interpretive frames for mobilizing collective action (McVeigh 1999 \& 2009). As a researcher who specializes in conservative right-wing SMO's that align themselves with racism, I am interested in the ways in which various interpretive frames reflect the ideology of white supremacy, in this particular case the post-Second World War era of white southern segregationist protest against civil rights activism and federal civil rights reforms.

Platt and Williams's (2002) study is the most closely related to this research, where segregationist rhetoric is examined and classified into thematic categories. They analyzed segregationist letters sent to Dr. Martin Luther King Jr., expressing their vehement disagreement with his program of racial integration and goal of racial equality and see these letters as examples of segregationist ideology though often differing on the reasons for the preservation of segregation. They categorized the letters into four major variations on segregationist argumentation: (1) a religious construction; (2) a historical-scientific construction; (3) a secularpolitical construction; and (4) a symbolic construction (Platt and Williams 2002:342). They described these four variations on the defense of racial separation as different "ideological versions” (Platt and Williams 2002:329). While Platt and Williams understand their four ideological versions of segregation as various ideologically constructed responses to the perceived crisis of the collapsing southern social order, I understand white supremacy as the ideological foundation for the social system of racial segregation. The various rhetorical defenses of that system are treated here as collective action frame arguments with white supremacist ideology as their central intellectual logic.

Platt and Williams agree with and quote McMillen’s (1971) statement that the CCA's principal ideological orientation was white supremacy (Platt \& Williams 2002:330). However, they refer to the various segregationist defensive arguments as “differentiated ideologies” that 
were constructed out of the "shared cultural bedrock" of white supremacist ideology (Platt \& Williams 2002:341). I instead suggest that what Platt and Williams see as "differentiated ideologies" should be more appropriately understood as various frames of protest in defense of segregation with white supremacy as its ideological thrust. It can be argued that what I conceptualize as frames are extensions of broader ideological themes such as, Christian theology, scientific rationalism and American anti-Communism, but for purposes of research into segregationist rhetoric, white supremacist ideology is distinguished from segregationist defensive frame arguments which comprise the rhetorical and symbolic structure of that ideology.

\section{THE SEGREGATIONIST FRAME CONSTELLATION}

As noted in the introduction, to contribute to frame theory I propose a concept referred to here as frame constellation, a web of SMO frame rhetoric and symbolism that functions as an overlapping, intersecting and interrelated system of ideas which revolve around a central intellectual logic for collective action. The CCA's central intellectual logic was white supremacist ideology, a belief system rooted in the notion that whites as a race are distinct from all other racial groups by their presumed superiority, especially with regard to intelligence. The CCA's frames were its segregationist defensive arguments, which consisted of any, and all rhetorical and symbolic defenses of the social system of racial segregation as defined by the privileging of whiteness and oppression of non-whites, especially blacks.

The frame constellation is a template for mapping out the broad ideology and frames of protest movements. This is not different from a codebook used for a content discourse analysis. The protest frames are all thematic categories for coding discourse in the codebook, which together comprise the rhetorical and symbolic structure of movement ideology. Protest movements deploy frames to shape public discourse on issues most relevant to the cause for collective action. These protests frames are deployed in ways that reflect movement ideology. To do a content discourse analysis on frames then, is to map out the dynamic structure of that 
ideology. This research aims to provide such a map of what has been regarded as the most significant conservative right-wing movement of the early post-World War II, Cold War civil rights years. Using the CCA as the main case study, and the KKK and elite segregationists for comparison, this research aims to provide the frame constellation as a useful conceptual tool for analyzing other protest movements.

After a detailed proposition in the next chapter, I then use the frame constellation as a conceptual tool for a qualitative content discourse analysis of the major propaganda media platforms of the CCA in chapters three and four. In chapter five, I perform a quantitative analysis of all coded data from CCA media, which centers on the question of what factors drive frame messaging. In this case, what influenced how the CCA deployed its various segregationist frame arguments? I hypothesize that geopolitical contexts, as independent variables, were significant factors that drove CCA framing. This will be comparison tested against a "geopolitically untethered” independent variable. Because the CCA aimed for national appeal in America, I also hypothesize that most of its frames were deployed in the domestic context of U.S. geopolitics. The National/Domestic U.S. will be treated as one type of independent variable that will be comparison tested against two others: a South (Local and Regional), and a Global/International Context. Finally, because anti-Communism dominated America's political culture in the several decades after World War II, one should expect to see anti-Communist frame-messaging as not only one of the highest frequently deployed in the CCA's propaganda media campaign but also it will be overwhelmingly deployed from a U.S. domestic context since the CCA aimed for national appeal. 


\section{CHAPTER II: WHITE SUPREMACIST IDEOLOGY AND SEGREGATIONIST FRAMES}

\section{THE PROPAGANDA VOICE OF THE SEGREGATIONIST MOVEMENT}

The Citizens' Councils of America (CCA or Council), was the propagandistic voice of massive resistance. Throughout the South the Council manifested itself in ways that were expressions of diversity in southern regional social dynamics. CCA associations, as originally envisioned, were primarily oriented towards sub-regional concerns and functioned as relatively independent local organizations. This complicated organizational efforts to develop a single coherent framework in which movement ideology could be systematically articulated. Despite the decentralization of the Council there was a shared collection of historically-rooted cultural notions the movement largely embraced.

Primarily the ideology of the Citizens' Council was the ideology of white supremacy. Like Negrophobes of an earlier age the Councilors rested their case for white dominance on the postulate that Negroes were inherently different from Caucasians and that this difference, this hereditary inferiority, rendered them unsuitable for free association with white society. In the Council's view the black man's presence could be tolerated only so long as the range of his economic, political, and social interaction with the white man's world could be systematically defined. In the Council's syllogism of white supremacy, then, segregation was the conclusion that necessarily followed the premise that human worth is calculable in terms of apparent physical characteristics (McMillen 1971:161).

If "the basic social philosophy of massive resistance was the myth of white supremacy (Wilhoit 1973:58),” this complex system of ideas needs analysis in order to uncover the intellectual logic of the CCA which was at the center of that movement. This research takes up the challenge to delve deeper into the collective consciousness of massive resistance by focusing on the multifaceted rhetorical tradition of white supremacy. Because ideology functions as the “dominant discourse of a movement” (Westby 2005: 220), and because of the immensity of white supremacist thought as exhibited in the post-1954 propaganda effort against civil rights, a useful 
theoretical template is necessary to make sense of it as an ideology composed of interrelated rhetorical defenses of segregation. This task can be accomplished with frame theory as explained in the previous chapter.

In the next section I describe six major collective action frame arguments frequently deployed by southern segregationists in general and the CCA in particular. These frames were expressions of white supremacist ideology aimed at defending the social system of racial segregation. These six frames do not represent the totality of the wide array of segregationist argumentation, but were singled out for elaboration because they have received the greatest and most thorough scholarly discussion, particularly by historians, as specifically related to the ideology of the CCA. These six major frames include (1) the anti-Communist frame; (2) the antiracial miscegenation frame; (3) the Christian/Biblical Frame; (4) the science frame; (5) the states’ rights frame; and (6) the outside-agitator frame. Although I have constructed for analysis six separate pro-segregationist frame arguments, in reality these concepts do not function independently of one another. In fact they are all interrelated and are often used in ways that intersect and overlap, and all function to reinforce the ideology of white supremacy. It is important to provide a discussion that tethers the components of the frame constellation to their social-historical contexts, especially as related to the CCA. This will help to illustrate how these frames function traditionally in the South as interrelated aspects of white supremacist ideology.

\section{SEGREGATIONIST FRAMES AS RECOGNIZED IN THE HISTORIOGRAPHY}

\subsection{The Citizens' Council and the Anti-Communist Frame in Historical Context}

In seeking to stave off desegregation, resistors put forward a complex web of arguments and counter arguments for perpetuating racial inequality, the vast majority of which had been used by the South for well over a century. While wider attitudes toward explicit racism had changed over time, however, the vast majority of the defenses of the southern segregationist position had not altered since the Civil War, and as a consequence some of the most trusted weapons in the southern armory were beginning to look decidedly wearied by the $1950 \mathrm{~s}$. The new vocabulary of the Cold War, coupled with a shared willingness by 
segregationists to adapt to their surroundings, proved to be a revitalizing force for many of the more traditional forms of southern defiance (Lewis 2005: 127).

Lewis (2005), as I argue here, suggests the anti-Communist frame can be thought of as a reimagining or recasting of older white supremacist arguments that were linked to a larger constellation of more traditional frame arguments. These frames functioned collectively as a package of white southern rhetorical defenses of segregation that reflected the larger ideology of white supremacist thought. What the Cold War geopolitics of anti-Communism offered to southern segregationists was a rejuvenation of older more traditional defensive arguments that provided to them an array of rhetoric unavailable prior to the emergence of the post-war bipolar geopolitical culture (Lewis2005). Anti-Communism was a nationalist impulse that was regionalized in the white southern tradition of Confederate nationalism (Woods 2004). Segregationist anti-Communism can be thought of as a neo-Confederate nationalism that functioned in part as a "defensive tactic" against the Cold War geopolitical imperative to desegregate under international pressure from human rights critiques. Though the political landscape on race issues seemed to be shifting to the relative disadvantage of white southern opponents of racial equality, the segregationist position was buttressed by anti-Communist politics to the degree nonconformist cultural impulses could be portrayed as antithetical to what was understood to be essential American ideals (Crespino 2007: 51-52).

The Citizens' Council's embrace of anti-Communism must be understood in the context of the various rapid socioeconomic transformations in the South, which created an atmosphere of hyper-patriotism as a response to a perceived threat to southern traditions. Conservative southerners in particular embraced conspiratorial notions as a way to explain these rapid economic changes and social upheavals in the post-war era. What emerged out of various conservative reactions to the civil rights revolution was an "organized resistance movement” that “took readily to Red-baiting.” Southern segregationists saw a necessary link between Communist 
ideology and racial integration/racial equality. Desegregation was something Communists agitated for, and the ulterior motive for Communist racial agitation was the destabilization of the social fabric of America as a means to destroy the United States from within. Casting itself as America’s premier and sole organization for the defense of white civilization, the Citizens' Council tasked itself with identifying the presumed Red-menace that plagued southern race relations. After the race issue, the Communist threat was the most significant preoccupation of Citizens’ Council segregationists (McMillen 1971: 195-196).

Although the NAACP and its supposed link to an international Communist conspiracy was a prominent theme in Council propaganda, McMillen does note however that not all Council leaders attributed southern black protest to a Red conspiracy but instead to a longer tradition of equal rights political ideology in America. In fact, McMillen writes, “a sizable faction within the Council, including some of the most articulate professionals on the CCA staff, insisted that the movement must be anti-Negro first and foremost, and only incidentally anti-Communist” (McMillen 1971: 199). Delving too deeply into anti-Communism could have the unintended consequence of serving as a distraction from the central goal of the preservation of racial segregation. Lewis also places great emphasis on diversity of opinion within the southern white resistance movement on the question of Communism. A segregationist had to be mindful of striking “a balance... between using the Cold War to bolster the segregationist cause and falling victim to the conflict's wider concerns” (Lewis 2005: 124). McMillen does clarify that although Citizens’ Council leadership were not monolithic in their orientation towards Communism, “Their differences, however, were largely of degree rather than kind” (McMillen 1971: 200). The Citizens' Council generally interpreted the problem of race in America in domestic and international terms, and did not differ in the main aim of thwarting civil rights reforms that regarded whites and blacks as equal in society. 
According to Bartley (1969), the concern with anti-Communism was not a genuine sincere argument among the more traditional pro-segregationist arguments. The effort by opponents of civil rights to link the black freedom struggle to a foreign Communist conspiracy, he writes, “... represented the greatest deviation from past justifications of white supremacy” (Bartley 1969:185).Bartley describes southern segregationist anti-Communism as a “...pseudonationalist campaign to discredit the civil rights movement generally and the NAACP in particular” (Bartley 1969:185). While some scholars such as Bartley may interpret segregationist anti-Communism as purely cynical, more recent scholarship has argued that the segregationist concern with the threat of Communism should be taken more seriously(Lewis 2004 \& 2005; Woods 2004; Crespino 2007; Ward 2011). According to Crespino (2007), segregationist antiCommunism was indeed an attempt to link the southern defense of segregation to broader themes on the national stage. But from the perspective of southern whites, their effort against the plague of Communist infiltration was not merely a regional concern with the defense of the racial status quo, but rather “...a uniquely American one, with traditional American principles at stake” (Crespino 2007:49).In contrast to Bartley, Lewis emphasizes the point that southern antiCommunism was not a mere knee-jerk reactionary attempt by segregationists to co-opt antiCommunist politics. Crespino contends that segregationist attempts to link their regional concerns to national ones preceded 1954and can be seen in the earlier 1948 Dixiecrat Revolt, which later reemerged in the post-Brown period as a movement to defend segregation. In the South, there was a longer tradition of hostility to American progressive equalitarianism and its relationship to Communism.

\subsection{The Citizens' Council and the Anti-Miscegenation Frame in Historical Context}

In post-Second World War America, especially after the Brown (1954) decision, the specter of racial miscegenation was perhaps the greatest of concerns by defenders of segregation. Updated for mainstream consumption, the traditional anti-miscegenation frame was refashioned 
and incorporated into the politics of Cold War anti-Communist red-baiting (Lewis 2005). The Citizens' Council of America was at the heart of southern white mobilization, and according to McMillen, “Almost from its inception...[it]...equated the drive for Negro equality with a Marxist plot to destroy America by sapping its Caucasian energies through miscegenation” (McMillen 1971:195).

Racial miscegenation was the most acute of segregationist anxieties and therefore antimiscegenation messaging functioned as the most powerful of propaganda against integration. For the Citizens' Council, its anti-miscegenation propaganda functioned as the perhaps the most appealing of the segregationist arguments. Negroid blood, it was asserted, carried with it the germ of society's demise. Racial intermixing was therefore a threat to the stability of civilization. Various Negro vices believed to be embedded in the blood, were put forward as reasons to prevent integration. The Negro race, according to segregationist thought, possessed inherently inferior characteristics including the innate propensity toward criminality and a natural susceptibility to high incidence of disease. For the Citizens' Council, integration was always equated with miscegenation, and segregation therefore provided the most logical solution to preventing the proliferation of socially undesirable qualities. Racial integration would invariably lead to racial miscegenation which would lead to the mixing of the believed-to-be, inherently inferior blood of the Negro with that of the presumed superior Caucasian. The very qualities that distinguished the races from one another — the supposed savagery of the Negroid race and the apparent civilized virtues of whites - were biologically embedded in the plasma of the blood. To mix the two would produce the inevitable destruction of modern man (McMillen 1971).

It is important here to provide a more in-depth discussion of the anti-racial miscegenation frame, particularly the taboo of interracial sex, which should be properly situated in a broader geo-historical understanding. Scholars of interracial sex and the duality of 'white desire' in European colonial context have shown how the fear of racial mixture facilitated white self- 
identification (Stoler 1995; Perry 1997; Young 1999; Stoler 2002; Osha 2008). Regulating sexual relations was at the center of that which defined the colonial power structure. Colonial policies that regulated marriages and sex ratios, for example, were of major concern and sex was perceived as a potentially dangerous medium through which the colonial power structure as defined by race and gender, could become destabilized, unravel and collapse. Therefore, racial boundaries were drawn as a way to ensure the regulation of sexual interaction, especially to 'protect' white women. Socially constructed identities were functional to the colonial project and the regulation of sexual interaction was the process by which the colonial politics of exclusion was maintained (Stoler 2002).

Preoccupation with the racial 'other', and fear of racial intermixture, characterized the sexual economy of white desire (Stoler 1995). White desire was defined by the paradox of attraction and repulsion; a struggle over figuring out the full extent to which colonial power could be manifest though white supremacist ideology, which involved interaction with nonwhites, while simultaneously avoiding contamination by the supposed inferior indigenous culture. In other words, colonialism carried with it the inherent risk of subversion from within, which points to the ambiguity of colonial power dynamics (Stoler 2002). Fear of the subversive effects of racial hybridity defined colonialism, where colonial administrators, for example, were ever concerned with white men's inability to restrain their sexual passions and avoid engaging in sexual acts which complicated and blurred power relations between the reputed superior race and the reviled but desired, inferior subhuman colonial subjects. The duality of desire for the racial 'other' functioned as a repulsive entity that had to be managed and regulated to avoid irrevocable contamination, but simultaneously interacted with to produce the 'self' as the superior being (Young 1995).

Because of the asymmetries of class stratification, whites were socialized to be ever aware of and avoid the temptation to engage in sexual activities which could subvert the system 
in ways that frustrated the imperialist aims of domination. This led to an entire structure of rules, habits, customs, social norms and enforcement mechanisms aimed at thwarting the believed tendencies toward social behaviors that did not conform to the imperatives of the state. Again, the preoccupation with the supposed 'dividing lines' of gender and race suggest the ambiguities of social interactions via race, as the colonial state aimed to homogenize the complexities of social reality. European colonialism in all its varied forms, was an exercise in cultural reductionism; the attempt to universalize colonized peoples under one standard of racial hierarchy at the service of imperial domination (Stoler 1995).

These conceptualizations also apply to the American historical context. The maintenance of clear racial boundaries was functional to the economic imperatives of the plantation economy and the preservation of the power structure, particularly in the colonial American South, as in the broader European global colonial adventures in Africa, Latin America and Southeast Asia. In America, erecting an ideological artifice upon which to base racial oppression, especially concerning interracial sexual taboos, began in the colonial period and continued through the Revolutionary era. Thomas Jefferson, for example, was part of a culture of American intellectuals who were devoted to constructing imagined communities where the boundaries of race were clearly delineated. The racial notions of Jefferson and other white elites of his era should be treated as ideology that reflected little about the actual nature of race relations in early American society (Rothman 1999).

Beyond early America, the culture of anti-miscegenation was maintained up to and through the Civil War years. It was perhaps even strengthened in the aftermath of the Reconstruction, being codified into the laws of Jim Crow segregation and occasionally reinforced with white vigilantism in the form of lynching. Anti-miscegenation laws lasted beyond the United States Supreme Court's desegregation decision in Brown (1954), remaining in the legal code 
throughout the American South until 1967 when the U.S. Supreme Court, in Loving v. Virginia ruled these laws to be unconstitutional (Finkleman 1997).

\subsection{The Citizens’ Council and the Christian-Biblical Frame in Historical Context}

Just as civil rights activists and pro-segregationists struggled over meanings of American citizenship via the politics of anti-Communism, so too was the civil rights era a conflict over and between religious narratives of American society (Dailey 2005). For opponents of racial integration, making an affirmative case for the legitimacy of segregation on the basis of theological morality was different from merely defending it (Crespino 2007:66). After Brown the Citizens' Council initially had difficulties in attempting to position itself as the authority on religious interpretations of segregation. Official policy of much of the Protestant South was to accept the Supreme Court's decision and elite religious figures in the South hardly endorsed the segregationist cause. Instead, the religious fervor in defense of segregation was largely reflected in the population of lay people (Chappell 2005). More often than not, the public position of church hierarchies was incongruent with local rank and file congregational membership (McMillen 1971). Following the Brown decision, local congregational bodies and their laypeople often conflicted with regional Church authorities. In instances where church leaders defied the will of their pro-segregationist congregations, ministers were usually ejected from their positions. As many local churches began to assert their own autonomy in objection to the Southern Baptist Convention and other regional southern white religious institutions, the struggle over the question of integration and their commitment to segregation became a contest over "cultural legitimacy" (Dailey 2005:164-165).This was the social space from which the Citizens’ Council could find expression as a grass-roots movement that saw no inconsistency between the "brotherly love" teachings of New Testament theology and the notion of a divinely sanctioned racially segregated social order (McMillen 1971). As internecine conflict over desegregation plagued southern white 
congregational bodies, Citizens' Councils gave voice to those among the Christian South who rejected the Court's decision (Crespino 2007).

Just as it was argued by pro-segregationists that Jim Crow was divinely ordained, opponents of segregation were portrayed by organizations like the Citizens' Council as agents of the forces of darkness, as foreign infiltrators in disguise working to corrupt those most susceptible to the alleged evils of liberal racial equalitarianism. This was primarily one of the ways in which the geopolitical concerns of the day, in the form of anti-Communism, were woven together into the tapestry of southern white religiosity and racial segregationist politics. McMillen describes the nexus between the anti-Communist frame and the Christian/Biblical frame below.

If segregation had the sanction of the providentially inspired writings and the approval of the Son of God, then integration could only be sinful, the work of either Satan or (as Council propaganda came increasingly to assert) his blood brother, Karl Marx. Indeed, the whole "myth of equality” could be traced to those in the various "-isms" — socialism, communism, and one-worldism—which threatened the ultimate annihilation of all Christendom. Accepting this myth, and declaring segregation un-Christian, the general assemblies of the region's major denominations became the dupes of "false prophets” (McMillen 1971:177).

There was a commonly held notion among Citizens’ Council membership that Communist infiltration would penetrate through the soft entry point of moderate churches where the apparent false teachings of liberal theology had already taken root. The Citizens' Council therefore, saw itself as a cleansing agent that would purify the church through an all-out offensive against the more liberal-minded clergy who had embraced the "un-Christian” teachings of racial harmony, and abused their exalted positions by abandoning fundamental tenets of American ideals (McMillen 1971). A major concern of Citizens' Council members then was the strategic inclusion in their movement of sympathetic church leadership. Citizens' Council organizers made an effort to bolster the notion that liberal-minded ministers were wrong-headed and naïve at best, at worst, under the influence of the devil, and that God did indeed sanction the separation of the races on earth. Council publications featured sympathetic church leadership engaging in 
theological defenses of segregation, and with recruitment in mind, the organization selected ministers who were regarded for their influential standing among middle-class churchgoers. These relatively well respected ministers with the voice of white southern morality, were valued not only for their intellectual contributions to the segregationist movement, but also as a financial resource for the funding of Citizens' Council publications, and for their effectiveness at organizational outreach and recruitment (Crespino 2007).

There were a litany of biblical passages that segregationists relied upon to provide a rationale for white supremacy and, although Dailey (2005) notes that segregationist religious arguments were constructed in strategically calculated ways, according to Crespino (2007), Citizens' Council theological defenses of segregation were ambiguous and often conflicted on the question of whether it was to be argued as a social system sanctioned by God, or one to be thought of as a purely civil matter to be dealt with in the realm of politics. According to Crespino, two perspectives were advanced by ministers before the Citizens' Council, which suggests inconsistency in thought. One line of logic proposed that segregation should be understood not as a mere political matter but one of great theological significance, where racial separation was sanctioned by God, and therefore the biological and cultural distinctions between whites and blacks were to be respected in society for the perpetuation of a peaceful coexistence. The other notion contended that segregation was not so much ordained by God, but its existence in society was merely permitted by God, and man was therefore sovereign by default to make the political decision for the establishment and maintenance of racial separation. It was essentially therefore, a civil matter for political leaders to preside over (Crespino 2007). Indeed, as Chappell (2005) agrees, many southern white ministers were segregationist in their political position, but often made it clear that the white power structure was not explicitly supported by anything in the Bible. For many southern white religious leaders, the foundation for segregation rested with secular law, 
not Christian theology. In the final assessment, religious argumentation proved largely ineffective for the segregationist movement (Chappell 2005:142).

\subsection{The Citizens' Council and the Science Frame in Historical Context}

In constructing its pro-segregationist web of argumentation, the Citizens’ Council “... invoked God as readily as it did science”(McMillen 1971:171).According to McMillen, “The corollary to the Citizens' Council contention that segregation was the law of God is the assertion that it was also the law of nature” (McMillen 1971:178).John P. Jackson (2005), to date, provides the most thorough examination of the role segregationist scientists played in constructing sciencebased arguments in the defense of racial separation. For segregationists the rhetoric of scientific objectivity offered a more reasoned and dispassionate appeal than the fiery bombast of violent extremist groups such as the Ku Klux Klan and similar organizations which the Citizens' Council often contrasted itself with. Because of the special authoritative position of science in society, scientific racism potentially had a special persuasive cultural force behind it that other defenses of segregation perhaps did not possess. Those who can successfully claim scientific legitimacy often emerge victorious in public debates. However, the problem for segregationist scientists was that their racist views were largely out of step with mainstream academia by the latter half of the twentieth century (Jackson Jr. 2005).

The notion of racial differences as inherent facts of nature had been thoroughly rejected by mainstream professional science by the middle of the twentieth century. However, a devoted cadre of race science practitioners persevered in their efforts to expose what they understood as the truth: the equality of the races was a conspiratorial hoax perpetrated by liberal Communistleaning professors on an unsuspecting lay public in America. Just as in the case of liberal theology in moderate southern Protestant churches, segregationists similarly believed the germ of racial equalitarianism had infected the scientific community and tainted scientific objectivity.

Many white southerners subscribed to the notion that social science evidence employed by the 
NAACP in Brown had some connection to a larger Communist conspiracy, or at least had the support of Communist sympathizers. This “conspiracy argument,” as Jackson Jr. calls it, was a "self-sealing" line of logic which asserted that the overwhelming weight of scientific evidence supported the view of inherent racial differences and that mainstream academia conspired in an effort to suppress further research. He writes that, “The conspiracy claim gained persuasive power because the notion of ideologically controlled science was anathema to how science was widely perceived in U.S. culture” (Jackson 2005:14). Motivated by their conspiratorial reasoning, the main aim of segregationist scientists therefore, was to expose and discredit the hollow and baseless dogma of racial equalitarianism, a perspective which pervaded and was deeply rooted in academia; as maintained through rigid hiring and tenure practices that stifled free inquiry into the natural foundations for racial inequality. Segregationist political elites making the conspiratorial connection between the "liberalism" of mainstream science and Communism were often cited by the Citizens' Council in their propaganda messaging. Speaking for the mass of white southern opposition to the Supreme Court's desegregation order, Senator James O. Eastland before Congress in 1955 raised the specter of Communism and questioned the legitimacy of what he regarded as suspect social science used in the Brown case. This speech was immediately incorporated into the propaganda effort by the Citizens' Council and was distributed across the South (Jackson 2005).

Segregationist scientists were a minority in academia and were fully aware their views were out of step with the majority of their colleagues. However, since southern whites had a general distaste for any sort of scientific evidence in support of racial equality, and white superiority was a commonly held, enormously popular notion among the masses of southern whites, segregationist scientists saw the courts as the most advantageous forum for a fair hearing of their understanding of racial difference and the need for social policy that respected these presumed inherent natural distinctions. After Brown, segregationists organized themselves to 
counter the success of the NAACP's use of social science evidence to prove segregation was unconstitutional. Segregationists responded by providing testimony in courts of scientific evidence which supported the idea of inequality between the races (Jackson Jr. 2005).

In making the scientific case for racial separation, segregationists did not always rely on a strict adherence to biological racism. Sociology and psychology could be used just as effectively in providing a rhetorically scientific logic to white supremacist ideology. Though southern segregationists greatly criticized the role of social science reasoning employed in the Brown case, the Citizens' Council found great use in relying on IQ tests to support the notion of intrinsic disparities in the intellectual capacities of white and black children. With IQ scores, the Council suggested that a curriculum for a racially integrated educational system could not be created because of the inability of blacks to learn as well as whites. After the release of findings taken from a series of hearings before the House Committee on the District of Columbia in 1956that the educational underachievement of African American children was due to their inherent intellectual inferiority and not the product of underfunded segregated black schools, the Citizens' Council produced a twenty-page pamphlet summarizing the report which recommended that segregation be reinstituted for the well-being of both black and white students there (Jackson Jr. 2005:77).

\subsection{The Citizens’ Council and the States’ Rights Frame in Historical Context}

The staging ground in the fight for states' rights changed dramatically following the Supreme Court's decision in Brown v. Board of Education in 1954. No longer confined to the ballot box, states' rights defenders went to work in communities throughout the South, organizing at the grassroots to forestall desegregation orders. The most powerful of these massive resistance organizations was the White Citizens’ Councils (Frederickson 2001:218).

The ideology of the Citizens' Council most closely mirrored that of the States Rights Democratic Party of 1948, and from the inception of the post-Brown segregationist movement the political philosophy of states' rights was a key unifying theme in the white southern resistance effort against civil rights. At the core of states’ rights was firm belief in the marginalization of the 
Negro (McMillen 1971:189-190).In fact, according to Wilhoit (1973), states’ rights political philosophy and white supremacist ideology were inextricably intertwined. Like white supremacist ideology, states’ rights logic was composed of “... a mixture of slogans, symbols, and verbalized propositions, most of which were born in antebellum political theory” (Wilhoit 1973:62).

Wilhoit (1973) lays out the articulated political philosophy of what he refers to as states’ rights federalism. In its pure legal theoretical tradition the United States is seen as a collection of independent states as set forth in the U.S. Constitution, where the federal government exists for the sole purpose of reflecting the collective will of these states. States, as independent agents, may act on behalf of the interests of its residents even and especially when the federal government behaves contrary to the well-being of the people. The states' rights perspective emphasizes decentralization and sovereignty of the states as autonomous, separate political entities existing as a union only for mutual preservation (Wilhoit 1973).

States’ rights philosophy was part of the intellectual foundation for The Southern Manifesto in which the perspective is cited as the legal basis upon which the South's state governments could defy federal civil rights reforms. The Supreme Court, it was asserted, cannot render decisions that pervert the Constitution to the will of an abusive central governing authority, but instead must respect the Constitution and all its amendments as explicitly written. The executive branch has no constitutional authority to intervene in the matters of states without the consent of the states. And the Congress cannot go beyond constitutional limits by legislating in ways that intrude into and violate the sovereignty of the states. States' rights federalism then, is essentially a political philosophy that aims to set strict limits on the nation's central government through an emphasis on regionally fragmented sovereign political units.

The alpha and omega of American federalism is, in the final analysis, the sovereignty of state governments. Therefore, if federal authorities attempt to coerce the states into acting against the expressed will of their people, the states have the right, and indeed the duty, to resort to interposition or nullification to prevent the unconstitutional exercise of federal power (Wilhoit 1973:69). 
Wilhoit warns however, that the pure legalistic theorizations of states' rights federalism disguise the social historical context in which the political philosophy developed. States' rights federalism must be understood against the backdrop of southern white supremacist ideology and the social system of segregation.

Yet, in spite of their intellectual and moral sterility, the mix of white supremacy and states'-rights federalism form the hard-core of the legitimizing ideology of the South's counterrevolution. Designed as much as anything to palliate southern guilt over discrimination against blacks, these myths were conceived in the Old South and were revived and refurbished in the wake of Brown. Their persistence into the New South was one of the fundamental causes of the "cultural lag" and tension that characterized southern society after 1954 (Wilhoit 1973:70).

Describing the nexus between states’ rights and anti-Communism, Lewis (2005), notes that the rhetorical shift to the Cold War era red-baiting of civil rights was functional to the resurrection of the older segregationist states' rights refrain, which stretched back as far as the Confederate nationalism of the Civil War era. The problem with the states' rights frame in the post-World War II era however, was its legal weaknesses. The states' rights argument, often put forward by southern political elites in defense of segregation, did not have a sound constitutional basis in which its logic could be grounded. Attempting to resurrect and strengthen states’ rights, southern segregationists found a perhaps more solid legal and political foundation in the antiCommunism of the early Cold War years. Connecting the older more traditional states' rights philosophy to the anti-Communist political culture of the day allowed southern segregationists to position their cause as one that would do more than merely free the South from the scourge of civil rights forces, but would more importantly protect the entire nation from the threat of Communist take-over (Lewis 2005:130).

\subsection{The Citizens’ Council and the Outside-Agitator Frame in Historical Context}

The notion of "outside agitators", as traditionally conceived in the American South, should also be conceptualized in the tradition of the South’s Confederate nationalism (Woods 
2004). As Woods states, "Southern fears of outside agitators and black rebellion contributed significantly to the social, cultural, and psychological tension that gave rise to southern nationalism and a separate Confederate state.” The outside-agitator frame should therefore be understood as one of the oldest defensive arguments in southern white supremacist tradition. It originated as early as the antebellum era to discredit the abolitionist movement as a foreign corrupting influence on the slave population. Its use continued in the South beyond the post-Civil War/Reconstruction era and would later be adapted to the early twentieth century Red Scare years, and again in the post-World War II early Cold War years (Woods 2004:14).

The consistent theme in the notion of "outside-agitators," from the period of plantation slavery to the civil rights protests of Cold War America, was that black unrest was fomented by those from outside the South. Southerners largely regarded their black population as unsophisticated and therefore incapable of organizing against a social system that ultimately, it was asserted, benefitted Negroes. Black southerners, it was reasoned, would not protest against their own self-interests as recipients of the virtues of white civilization. Only those who did not appreciate the complex relationship of blacks to whites would engage in acts of subversion. With this in mind, it was argued that wishful-minded Yankee northerners were ultimately the instigators of social upheaval.

Pro-slavery ideology, as expressed by those who engaged in rhetorical defenses of the southern plantation economy, portrayed black-white relations in the South as mutually beneficial, where the civilizing influence of white society acted as a check on black savagery. The untamed power of Negro animalism, if successfully pacified, could be harnessed and used for the greater good of modern society. As stewards of civilization, whites had a responsibility to maintain order and avoid risking anything that would cause social instability. In the earlier age, plantation slavery was the social mechanism by which the South would harness the raw energy of black 
savagery, while remaining ever vigilant in instituting necessary control measures which ensured the preservation of the status quo.

After the Civil War the racial hierarchy was reorganized and adapted to the social system of Jim Crow, where the logic of racial-symbiosis was similarly applied to twentieth century segregation. Just as southern whites of the pre-Civil War era defended the "southern way of life" against foreign intruders, especially naïve northern white abolitionists who failed to see the virtues of black-white mutual dependency, post-Brown southern whites in the Massive Resistance movement, likewise aimed their ire at those who sought to corrupt the otherwise passive Negro population with alien un-American notions of racial equality (Wilhoit 1973; Lewis 2004; Woods 2004).

The southern white defensive refrain of "outside-agitators” in the early Cold War years, as used by segregationists, merged traditional themes together with the politics of antiCommunism, thus taking the South's regional ideology of xenophobia and connecting it with more mainstream American nationalistic impulses. Just as Lewis (2004) sees Cold War antiCommunism as a revitalizing force in the older tradition of states' rights argumentation, he similarly describes the re-emergence of the white southern notion of "outside agitators" as becoming almost completely synonymous with the perceived foreign influence of Communist subversion.

Most white Southerners were traditionally wary of "outsiders," a term that they employed somewhat idiosyncratically to denote anyone unsympathetic to the regions racial practices. As outsiders, so it was argued, not only did agitators have no right to comment on the South's racial situation, but they could also not hope to grasp its subtleties. Communists fitted the southern perception of "outsiders" perfectly and were depicted as intent on bringing racial tumult to the region to rival that wrought by Reconstruction. One of the most popular ways of attempting to retard such an upheaval, therefore, was to suggest that it was communist-inspired (Lewis 2004:14). 


\section{THE FULL SEGREGATIONIST FRAME CONSTELLATION}

The previous section provided a detailed discussion of the social-historical context in which to understand six major segregationist frame arguments. The above six frames do not represent the totality and wide array of segregationist argumentation, but were singled out for elaboration because they have received the most thorough scholarly discussion, particularly as related to the movement ideology of the CCA. Because these six frames have a more voluminous scholarly treatment there was relatively little intellectual burden in conceptualizing them as collective action frame arguments. The vast majority of frames presented in this research were discovered through a content discourse coding analysis of the CCA's propaganda media campaign. Like the six frames previously discussed, what all of these additional frames have in common is their function as recurring thematic arguments in defense of racial segregation as the social prescription for the presumed superiority of whites and inferiority of blacks.

These various segregationist arguments comprise a constellation of frames that serve the same central intellectual logic of the grand movement ideology of white supremacy. Based upon my analysis of the CCA's propaganda media campaign, the frame constellation includes 28 main frames (frames that reflect the main segregationist argument being made), 25 sub-frames (frames that follow a particular aspect of the main segregationist argument), and 4 sub-topic frames (frames that are focused on an even more narrow aspect of the sub-frame from which it extends). The frame constellation I constructed was used as a code book for the content discourse coding analysis of CCA propaganda media using NVIVO. The coding involved meticulous examination of the entire text of the three CCA data sets discussed in the previous chapter. In the coding process a single word, phrase, sentence, paragraph or even an entire page (in the case of the official paper or official journal) or segments of programs or entire programs themselves (in the case of the broadcast films), would be selected for categorization under a specific theme as defined in the frame constellation codebook. The code book, featured in the next section, contains 
a complete listing of theme-names categorizing the coded data, organized alphabetically with definitions. The 28 main frames are in bold-type, the 25 sub-frames are located just underneath each respective main frame next to bullet points and are italicized, and the 4 sub-topic frames are indicated next to Roman numerals.

\subsection{Segregationist Frame Constellation Codebook}

1. Agitator Frame: Race relations in the South under segregation are essentially harmonious and therefore those who "agitate" for change to the status quo are disturbing an otherwise peaceful coexistence between whites and blacks. Keywords to look for include but are not limited to: agitator, outside agitator, race agitator, and instigator. The agitator frame has two sub-frames: outside-agitator frame and race agitator frame.

- Outside Agitator Frame: references to agitator that specifically uses the phrase "outside agitator" or refers to outside instigators, or those from outside of the South who come to stir up trouble in an otherwise peaceful and harmonious racially segregated society

- Race Agitator Frame: references to agitator that specifically uses the phrase "race agitator" or "race incitation"; that racial problems are the cause of race agitators and race instigators

2. Anti-Communist Frame: references to communists as the cause for racial division in the United States particularly in the South; that communists are in fact conspiratorial orchestrators of black protest and that the ultimate source of civil rights activism and federal government endorsement of civil rights reforms is a product of a grand Soviet communist conspiracy

- Foreign Policy Critique Frame: references to communists as specifically related to southern segregationist foreign-policy critiques, particularly of the State Department and U.S. foreign aid, and U.S. military strategy overseas against communist nations or communist militants

3. Anti-Racial Miscegenation Frame: references to interracial sex, racial intermarriage, Negro rape against whites

4. Anti-Rightwing Militant Extremism Frame: references made contrasting the CCA with presumably more violent segregationist organizations and violent acts of right-wing extremism 5. Anti-Socialist, Liberal, Leftist Frame: references to the idea that there is a spectrum of ideologies which pose varying degrees of threats to the health of America's political culture in particular and wider social and cultural fabric in general

- Leftist Frame: references to leftists as hard-core advocates and defenders of an unAmerican racially integrated society to ultimately lay the foundation for communist takeover

- Liberal Frame: references to liberals as wishful thinking do-gooders in their naïve endorsement of un-American racially integrated society to unwittingly lay the foundation for communist takeover

- Socialist Frame: references to Socialists as unrepentant ideologues in their hard-core political commitment to bringing about a revolution in American society that would welcome racial integration and enthusiastically and unapologetically bring about the communist takeover of America 
6. Collapse or Destruction of Civilization Frame: references to the idea that abolishing segregation and instituting racial integration will lead to the collapse or destruction of civilized society especially and particularly the United States and Western civilization as a whole

7. Discrimination Against Whites Frame: references to the idea that the erosion of segregation in exchange for racial equality and integration will lead to greater discrimination against whites whether in the labor market, or with regard to personal and individual freedoms

8. Freedoms Frame: references to freedom in America being under threat by those who advocate racial integration and racial equality and the abolition of white dominated racial hierarchy

- Freedom of Association Frame: references to threats to white rights to freely associate with one another to the arbitrary exclusion of blacks in particular

- Freedom of Choice Frame: references to threats to the freedom of choice by whites to continue to engage in the tradition of racial segregation

- Individual Liberties Frame: references to the idea that the liberties of the individual are under threat by those advocating racial integration

- Personal Rights Frame: references to the idea that personal rights are under threat by those advocating racial integration

- Property Rights Frame: references to the idea that property rights are under threat by those advocating racial integration

9. Global Struggle for White Rule Frame: Discussions of segregation in foreign nations, e.g. South Africa, as models to be emulated in social practice and preserved globally

10. Historical Lessons Frame: references the recent or distant past to construct arguments in defense of racial separation

- Ancient Civilization Frame: references to the idea that justifications for segregation can be found in the lessons that can be learned from ancient civilizations

- Civil War Era Frame: references to the idea that lessons can be learned from the U.S. Civil War era to defend segregation in the modern era

- Founding Fathers Frame: references to the idea that justifications for segregation can be found in the logic, reasoning and wisdom of America's founding fathers

- World War II Frame: references to the idea that justifications for segregation can be found in the lessons learned from the relatively recent World War II era.

$>$ Hitler and Nazi Frame: using the idea of Hitler and Nazi tyrannical dictatorial rule to illustrate or analogize the tyranny that would befall America if racial integration were to be forced upon the nation against the will and better judgment of citizens

11. Majority Opinion Frame: references to the majority of white southerners, or any population, being overwhelmingly in favor of maintaining segregation and opposed to integration

12. Nature Frame: references to racial segregation as 'natural' and integration as 'unnatural', especially when making comparisons of human social relations to non-human animals and their presumed 'natural' aversion to 'mixing' themselves with those 'not of their own kind'

13. Negro Contentment Frame: references to the idea that blacks are quite content and happy with the South's racial segregation system

14. Negro Intellectual Inferiority Frame: references to black educational underachievement, the under-performing of black children in public schools, evidence cited to support the idea of black intellectual inferiority

15. Negro Takeover-Domination Frame: references to Negroes as a kind of plague spreading into white communities, taking them over, or Negroes dominating politics through the vote, or the overall Negro population rising dramatically

16. Negro Vices Frame: references to Negro criminality, disease, immorality, intellectual inferiority 
- Negro Criminality Frame: references to Negro violations of the law as evidence for the idea that blacks are not fit for self-government and therefore must be contained within the necessary restraint of segregation

$>$ Negro Violence Frame: references to the idea that Negroes are violent and therefore must be controlled by racial segregation

$>$ Rape and other Sexual Violations Frame: references to the idea that Negroes are prone to rape and other sexual deviances and therefore must be controlled by racial segregation

$>$ Robbery, Theft, Stealing Frame: references to the idea that Negroes are prone to robbery, theft, stealing and therefore their behavior must be controlled by racial segregation

- Negro Disease Frame: references to the idea that Negroes, more than any other racial group, are very susceptible to dangerous and perhaps contagious diseases and therefore must be contained within the system of racial segregation

- Negro Dishonesty Frame: references to the idea that dishonesty is further evidence of poor character of Negroes in general and therefore limits must be placed upon their behavior within the system of racial segregation

- Negro Illegitimate Birth Frame: references to the idea that Negroes have no inhibitions on their sexual behavior to the degree that illegitimate births are an epidemic within their population and a general menace to larger society, and therefore this threat must be contained within racial segregation

- Negro Public Incivility Frame: references to Negroes behaving badly in public, being loud, rude, unruly, menacing and creating fear in the general white public

17. Northern and Non-South Support and Sympathy Frame: any claims regarding support for segregation existing in the North or outside the South in general

18. Northern Hypocrisy Frame: references to the North's own abuses of its northern black populations, or discussions of northern racism, discrimination and the like, as a way to note Northern hypocrisy on the issue of civil rights in general, segregation in particular, in its criticisms of the South

19. Protection of the Negro's Best Interests Frame: references to what segregationists understand as being in the best interests of Negroes; that segregation is the best social arrangement for the natural condition of the Negro and segregationists advocate on behalf of the Negro's well-being where matters of race-relations are concerned

20. Race Difference Frame: inherent racial differences between blacks and whites, whether by God or by nature, make it impossible for integration and best to maintain racial segregation 21. Racial Harmony Frame: references to the idea that southern racial segregation is really about harmonious race relations between blacks and whites; when whites maintain the civilized order within which blacks find their place and are even able to advance as far as the limits of their relatively inferior nature will allow

22. Racial Preference Frame: references to the idea that whites and blacks only prefer to associate with their own racial group and really do not want to integrate with one another 23. Religious Frame: any religious (especially Christian) justifications for racial segregation

- Anti-Integrationist Christian Frame: criticisms of Christians who have embraced integration, especially religious elites (including ministers, pastors and other clergy); or attempts to expose those in the Christian leadership who are integrationists

- Christian-Biblical Frame: segregation is compatible with and supported by true Christianity and the Bible upon which it is founded

24. Savage African or Savage Negro Frame: references to Africans as savages, wild, unruly, unfit for self-government, and in need of civilizing 
25. Science Frame: The use of scientific arguments in defense of racial segregation and white supremacy

- Biological Frame: The use of biological scientific arguments in defense of racial segregation and white supremacy

- Psychological Frame: The use of psychological (including statistical data), scientific arguments in defense of racial segregation and white supremacy

- Sociological Frame: The use of sociological (including statistical data), scientific arguments in defense of racial segregation and white supremacy

26. States' Rights Frame: references to states' rights, state sovereignty, rights of states, interposition, nullification; in particular with regard to the idea that the United States is made up of separate sovereign political entities (the states), and have the final say in decision-making matters regarding that which occurs within the borders of the states, especially racial matters 27. UN Tyranny-One World Government Frame: references to the idea that the United Nations is the clearest evidence of the first signs of a one world system of government under which American sovereignty will evaporate in exchange for a socialistic and perhaps even communistic new world order; and that the human rights agenda of the United Nations and civil rights movement in America support the same goal of a one world government

28. Un-American Frame: references to the idea that supporters of integration and opponents of segregation are essentially un-American

\section{THE SPECIAL SIGNIFICANCE OF THE ANTI-COMMUNIST FRAME}

I take the view that pre-existing ideologies can, in the context of social movements, function as frame arguments in service of a larger grand ideology. The power of movement ideology is its capacity to weave together seemingly disparate cultural perspectives, especially if these cultural world views have their own deeply rooted histories. These different cultural notions, which previously in some ways may overlap and intersect, function as a frame constellation when they are reoriented as an interlocking web of frame arguments that serve the same central intellectual logic of SMO ideology. In the case of American anti-Communism, for example, it retained its own capitalist expansionary logic (Harvey 2003), that militated against those within the United States and abroad seen to be at odds with what were understood at the time to be fundamental American ideals and values (Schrecker 1994 \& 1998; Whitfield1996;

Dudziak 2000; Gerstle 2001). However, in the context of the southern segregationist movement, anti-Communism was subsumed under the grand ideology of white supremacy, the central intellectual logic that was most ardently defended in the former Confederate states (Lewis 2004; Woods 2004; Ward 2011). The special significance of the anti-Communist frame argument, 
among all others, was that it was an effort in the segregationist massive resistance movement to bring a Cold War relevance to the various historically deep-rooted frames that comprise the structural artifice of white supremacist ideology. For the segregationist movement, antiCommunism functioned as the sort of frame that adapted older pre-existing elements of white supremacist thought to modern-day geopolitical concerns of post-World War II American culture. Using the frame constellation concept introduced in this chapter, I provide qualitative discussions of the three CCA data sets in the following three chapters.

\section{A BRIEF HISTORY OF THE CCA PROPAGANDA MEDIA CAMPAIGN}

In December 1956, the Education Fund of the Citizens' Council was created as a counter to the NAACP Educational Fund, but primarily to connect the Council to the national media outlets, including wire, print, television and movies (McMillen 1971). The organizations' literature and video media formats are the primary sources for investigation. The data for analysis include three major pieces of organizational propaganda media: 1) the official paper of Citizens' Council called The Citizens' Council; 2) a magazine called The Citizen; and 3) a television and radio broadcast series known as Citizens’ Council Forum.

The Citizens' Council was the monthly four-page official news print publication of the Citizens’ Council of Mississippi from October 1955 to September 1961. It functioned as part of the larger propaganda machine for the wider southern regional Citizens' Council branches, and for the segregationist white supremacist cause writ-large in the immediate aftermath of Brown v. Board (1954). By the year 1960, an average of 50,000 copies an issue for the official paper were being produced. The paper was published in Jackson, Mississippi with William J. Simmons as the editor, and was made available to the public for \$2 initially, and later \$3 for an annual subscription. A monthly magazine called, The Citizen, which replaced The Citizens' Council in 1961, was also produced. ${ }^{2}$ 
Not limited to newsprint, the propaganda effort by the Citizens’ Council included media outlets. By April 1957 the Council had entered broadcast through its fifteen minute, weekly programs, first through WLBT-TV in Jackson, which later expanded into radio and television in the first year (McMillen 1971). Produced by Dick Morphew, called Citizens’ Council Forum, these films consisted primarily of interviews with conservatives from the United States and some foreigners. Local television stations and national outlets aired these programs with the specific purpose of steering public opinion to the understanding that there was some fundamental link between integration and Communism. ${ }^{3}$

Citizens' Council Forum was shown on twelve stations in the states of Alabama, Georgia, Louisiana, Mississippi, Texas, Virginia; and in radio broadcast throughout the South on over fifty stations. Recording sessions for these radio and TV programs were strategically located in Washington D.C. for the advantageous use of government studio facilities (Bartley 1997). The cost of producing the Forum program was significantly low for the Council because of support from national political elites who orchestrated the use of governmental recording studios; significantly less than costs in the private market (McMillen 1971).

The enormous influence of the Citizens' Council in Mississippi’s political culture during the tenure of Governor Ross Barnett is illustrated in funding for the organization's propaganda media campaign through the Mississippi State Sovereignty Commission (Crespino 2007). In spring of 1960 the Sovereignty Commission provided significant subsidies to the Council’s media, radio and television programs. In May of 1960 under Governor Barnett, the Council began receiving regular monthly contributions (McMillen 1971). In 1960 the Council was appropriated $\$ 20,000$ through the Sovereignty Commission’s $\$ 250,000$ total funding. For the next four years, the Council received monthly subsidies which totaled $\$ 198,500$ by 1964 . The Sovereignty Commission cut funding to the Citizens’ Council on September 30, 1962 (Crespino 2007). 
When considering the totality of the segregationist propaganda effort, one must appreciate difficulty of evaluating its scope and impact. However, as Bartley (1997) has noted, the grassroots segregationist movement’s propaganda campaign, “Certainly...must have done something to harden white Southern sentiment and may have won some converts outside the region” (Bartley 1997: 189). In general, the southern segregationist propaganda campaign was part of a larger effort at enforcing social conformity, as racial integration was equated with disloyalty to the "southern way of life" and alien to broader American cultural values and principles. The segregationist propaganda campaign undercut the notion of free expression and its wrath was aimed at what was regarded as heretical according to southern cultural tradition. Citizens’ Council organizations throughout the South, Bartley maintains, “...were the cutting edge of the drive for regimented orthodoxy” (Bartley 1997: 190).

Complicating the segregationist movement's determination for cultural conformity however, were civil rights activists' attempts to appeal to more moderate sensibilities. Because of the relative success of civil rights activists in marginalizing the most zealous defenders of the racial status quo, segregationists had to concern themselves with the degree to which they could mainstream their message of racial separation and still adhere to core principles of white supremacist ideology (Crespino 2007). In light of this dilemma, segregationist anti-Communism in the South became a major strategy in nationalizing the southern regional struggle against integration (Lewis 2005).

The Citizens' Council’s propaganda effort was in a class “fully a cut above the crude productions typical of most segregation groups (McMillen 1971; 39).” In the next chapter the official paper, The Citizens' Council, is analyzed, followed by the television and radio broadcast series, the Forum in chapter four. Chapter five analyzes these three data sets to test the significance of the various frame arguments which comprise the Council's frame constellation, which will also be comparison tested against KKK and elite segregationist data sets. 
CHAPTER III. CITIZENS’ COUNCILS OF AMERICA OFFICIAL PAPER (1955-1961)

\section{REFINING THE SEGREGATIONIST FRAME CONSTELLATION}

Using the frame constellation concept proposed earlier, this chapter provides a detailed qualitative discussion of the CCA's official paper, The Citizens' Council (1955-1961), a sophisticated example of segregationist propaganda literature rooted in the long tradition of white supremacist thought. White supremacist ideology functions as the gravitational center around which all thematic arguments orbit in the segregationist frame constellation. The constellation itself is a dynamism characterized by interrelated, overlapping and intersecting notions which operate for the singular purpose of defending the segregationist vision of the cosmos; a system of social inequality as defined by a racialized hierarchy. Some segregationist frame arguments have been in circulation much longer than others and even predate the twentieth century system of racial separation, stretching as far back in time as the era of plantation slavery which functioned as an earlier institutional manifestation of white supremacist ideology. Older and more traditional frames go to the core of white supremacist thought, having roots as far back as the American colonial era and exhibit a specific and distinct white southern nationalist origin such as the outside agitator and states' rights frames. These specific frames, among others, are uniquely white southern cultural memes. Other frames are more recent in the cosmology of white supremacy, and reflect more modern twentieth century political cultural concerns, such as the anti-Communist frame, which can be conceptualized as a relatively modern addition to the complex system of collective action frame arguments that comprise the segregationist frame constellation.

The rhetoric and symbolism which comprise the frame constellation can also be conceptualized as a hierarchy because frames are not evenly distributed throughout the entire structure, but instead converge in ways that produce localized concentrations of frames, within which are other regional nodes of frames. The structural hierarchy of the frame constellation is 
composed of frame clusters, frame sub-clusters, and then the main frame arguments themselves. I define the major structural components of the frame constellation in the following. The frame constellation is the entire interlocking dynamic web of collective action frame arguments defined by core movement ideology. Frame clusters are relatively large regional assemblages in the constellation of frame arguments organized around a central subject related to core movement ideology. A frame sub-cluster is a relatively smaller number of tightly interconnected frame arguments structuring the larger frame cluster theme as related to grand movement ideology. A frame argument itself is the basic rhetorical and/or symbolic unit of a movement's ideological thrust. Conceptualizing the entire frame constellation in this way is useful for understanding the uneven and dynamic structural web of segregationist rhetoric and symbolism.

\section{OVERVIEW OF THE CITIZENS’ COUNCIL OFFICIAL PAPER}

The Citizens' Council official paper is indeed a sophisticated example of political craftwork by a conservative right-wing SMO. This impressive propaganda media platform often weaves together the constellation of segregationist argumentation with cleverly employed statistical data to create the sense for its readers that carefully reasoned dispassionate logic of scientific objectivity is being presented in defense of southern segregation and white supremacist ideology. However, the Council's paper does contradict this sophistication, especially in its political cartoons, which frequently reflect the American minstrel tradition of black ridicule. All of this contributes to the complex but blatant racism of the official paper. In its entirety, the official paper of the Citizens' Council features fascinatingly varied messaging that work in concert toward a common urgency of defending white southern traditions perceived to be under attack by epic un-American and ungodly forces.

Many articles discuss the coming plague and chaos of Negro domination if the black race is set loose by the dismantling of segregation. Other segments emphasize the sheer unruly nature of the Negro, especially the black youth who function as a public menace, terrorizing 
communities with their unrestrained inhibitions of thuggish hooliganism. There is also much discussion of the supposed intellectual inferiority of Negro children and therefore, the inherent futility of the attempt to integrate schools in America.

Many portions of the paper widen the geographic context in which to understand the significance of the threat to white civilization, highlighting the struggles of whites under siege by natives on the African continent. Theological rebuttals to "moderate" Christian endorsements of integration are also included. These articles often cite specific verses from the Bible to show that in fact racial segregation has for all time been sanctioned by the Creator of mankind. Also noteworthy is the NAACP as a constant target identified in the epic struggle to defend the South against integrationist forces of darkness.

Throughout the pages of its official paper, the Council employed a powerfully appealing grand narrative in which multiple agents of malcontent conspire in an effort to collapse the one nation standing as a champion for liberty and freedom in the world. In this grand conspiracy, Soviet-Communists operate as the head of an evil hierarchy, employing their allies in strategic weak points of American society. Relying on like-minded ideological adherents, including the hard-left and unrepentant Socialists, Communists organize their efforts in ways that exploit deep divisions in America's political culture. Self-interested politicians also play their role to help facilitate Communist infiltration, having little, if any, allegiance to a meaningful cause; interested in nothing else except self-aggrandizement.

Intricate and rich in detail, deep-rooted in its profound and numerous historical references, untamed in its racism, the immensity of the official paper is a challenge to systematically analyze. It must be filtered through the sort of qualitative discussion which captures its enormity, while uncovering the complex patterns of segregationist argumentation. This necessitates further refinement of the frame constellation concept, which is the focus in the next section. 


\section{THE CCA OFFICIAL PAPER AND FRAME CLUSTERS}

This qualitative discussion of the Citizens' Council official paper is organized around short essays which illustrate what I refer to as frame clusters, which can be thought of as regional constellations. Frame clusters are gravitational focal points or sub-regions located within the entire constellation of movement ideology and are composed of a relatively large grouping of frame arguments which cluster themselves in such a way that reflects a central subject. By discussing the official paper through short essays focused on frame clusters, the goal is to provide a cohesive, cogent and elegant articulation of how the frame constellation of the Citizens' Council is comprised of intersecting, overlapping and interrelated segregationist frame arguments.

The section that follows is organized around three major frame clusters. The first is titled, The Negro and the Segregationist Imperative, which features as its central subject all issues related to the Negro which necessitate segregation in society. In this frame cluster the necessity of racial separation is not only understood in historical, religious and scientific terms, but more critically in the context of national social upheavals and their relationship to larger geopolitical, especially anti-Communist-Cold War imperatives. The second frame cluster is referred to as, Ideological Un-Americanism, which focuses on the connections between various political trends in the United States which ostensibly run counter to fundamental American ideals, and larger Cold War geopolitics. The main idea here is that the political spectrum of subversion in U.S. domestic culture weakens America on the global stage of geopolitics against the Soviets and their international allies. The third and final major frame cluster is named, Struggle for the Preservation of Freedom, and is characterized by its focus on the protection of individual freedoms as manifest in the freedom of association, of choice, of personal rights and of property rights, especially as related to the right to freely decide with whom one will interact socially, politically and economically. As with the first two, the anti-Communist theme gives this cluster 
its geo-political cutting edge by raising the specter of Communist subversion of American freedoms.

The common defining characteristic of all three of these frame clusters is their function as sub-regional focal points in the larger frame constellation. As local regions, frame clusters exhibit primary subject matter created by concentrations of frame arguments. Frame clusters revolve in a manner which reflects the movement's central intellectual logic. In this case, white supremacy functions as the grand ideological focal point around which the three frame clusters named above orbit, while the litany of segregationist frame arguments themselves circulate around the frame clusters, often sharing similar frames in the larger cosmology of the frame constellation. Put succinctly, the frame constellation (like a galaxy), is a dynamism composed of similarly dynamic frame clusters (like galactic regions with high concentrations of stars), which function as regional orbital hubs for collective action frame arguments (like stars themselves).

\subsection{Frame Cluster 1: The Negro and the Segregationist Imperative}

In the paragraphs that follow, I provide a broad qualitative overview of this first frame cluster. The discussion is subdivided into sections, called sub-clusters that focus on regions in the frame cluster which feature more closely related frame arguments linked to a basic premise or primary narrative-logic. There are two identified sub-clusters for The Negro and the Segregationist Imperative frame cluster: 1) Racial Symbiosis and 2) Negro Depravity and Primitivism. The primary narrative-logic to Racial Symbiosis is as follows: If left unto itself, southern segregation functions as a harmonious, mutually beneficial system of racial reciprocation, uplifting the Negro to the extent that his nature allows, while facilitating the imperatives of modern society (white man's civilization), as manifest in the South. The principle idea to Negro Depravity and Primitivism is as follows: The inherent inferiority of the Negro, especially morally and intellectually, as a result of his savage, primitive nature, necessitates the imposition of an elaborate mechanism of social control (segregation). The connection between 
the Racial Symbiosis and Negro Depravity and Primitivism sub-clusters can be described thusly: If carefully engineered, segregation (as defended by the Citizens' Council and its supporters), will not only tame the primitive savagery of the Negro, but can also produce the outcome of a harmonious system of race relations vital to a modern, industrial, capitalist American nation under the stewardship of the more civilized white race.

\subsection{A Sub-Cluster 1: Racial Symbiosis}

There is a kind of logic at work in the ideology of the Citizens' Council which suggests the American Negro, despite what criticisms "race-agitators” may levy against the country or the South in particular, is better off than his African counterpart for having been exposed to the civilizing influence of white American culture. Civil rights activists and the federal government, as suggested by the Council, have conspired in an unholy alliance against traditional Americanism to foolishly set the Negro free from the supposed abuses of the South, when in fact southern Negroes have experienced nothing but the benefits of white civilization under segregation. According to this segregationist belief, racial harmony is the defining character of the southern racial order, and those who presume to act on behalf of the supposed downtrodden southern Negro are nothing more than troublemakers whose main preoccupation is stirring up racial strife in the South by agitating its people on racial issues that are otherwise settled. These “race agitators,” as they are often referred to by the Citizens' Council and pro-segregationists in general, are experts at riling up southern Negroes, instigating a general sense of ungratefulness for what the South has done to protect their general welfare by advancing their race to the fullest extent of their inherently limited intellectual capacity. These expert race agitators are in fact, according to the Council, often connected to anti-American elements and wittingly or unwittingly, serve the interests of Communists who seek to infiltrate the left-leaning civil rights organizations, disturb southern racial harmony and gradually erode the traditional social fabric the founders of this great nation sacrificed so much for. 
In constructing a narrative of Negro contentment with life in the segregated South, and in promoting the idea that racial separation was ultimately for the protection of the Negroes' best interests, the Citizens' Council official paper sometimes features what presumably are authentic black personal testimonials of their gratitude for receiving all the benefits of southern white society. In a piece titled, “Negro Citizen Writes,” James Maxie expressed utter gratefulness for being brought up in the South, writing, "I want to say that I am very happy to be a Mississippi Negro,” and that other blacks should similarly learn to appreciate being residents of the South. He particularly notes the "kindness of white friends" by providing him with spending cash, nice clothing and other valuable gifts. The letter ends with a mild admonishment of his fellow southern Negroes who he states, “...suddenly think that everything ought to be changed in Mississippi.” He also suggests that many other Negroes agree with his sentiments. The letter reinforces a common theme of the "happy" Negro and ends with the signature "A Happy Porter, James Maxie.”4

Another example of the Racial Symbiosis sub-cluster and its corresponding frames is in an article titled, “More Negro Teachers Lose Jobs As More Schools Are Integrated.” In this piece, concern is expressed over the jobless rate of Negro teachers as a consequence of public school integration. Because of the rapid decline in the black student population away from traditionally black schools, black teachers, it is claimed, are experiencing a sharp rise in termination of employment. The New York Times is cited in making the assertion that black teachers “...were dismissed because their own all-Negro schools have been abandoned and colored students absorbed in white schools.” While pointing out the negative impact of public school desegregation on the black teaching profession, an often stated theme is reiterated: Despite what criticisms have been levied against the South by civil rights “agitators”, southern Negroes are in fact better off and are afforded greater advantages in the segregated, white dominated southern social order. This premise is captured below in an excerpt from the article. 
Actually, the South today is a real land of opportunity for Negro teachers. Besides having more Negro educators, the South has more Negro college presidents, doctors, lawyers and prosperous business men than all other states combined. The great majority of colored citizens know and appreciate these facts, which is why agitators will never succeed in turning the Negro against his white friend here. ${ }^{5}$

A document called “A Manual for Southerners” frequently appears in the pages of the official paper and apparently was to be used as grade school educational material to, in the words of the Council, "impart to our children a true understanding of their origins and the reasons for our bi-racial society.” In a section aimed at fifth and sixth graders, it is emphasized that white southerners treated their slaves kindly and that many white laborers had it far worse than black slaves. This point fits in with the narrative of Southern white hospitality and overall general concern for the Negro's well-being, while simultaneously refuting the notion of white brutality against black slaves by noting the supposed experience of white industrial workers as being far worse than whatever black southerners ever endured in the American South. According to the Council in their "Manual for Southerners," "the Negro slave was almost always treated kindly by his white master," and "Any honest man will tell you that the Southern white man has always helped the Negro whenever he could.” In fact, as is contended in the article, southern Negroes enjoy a better way of life among white southerners than whatever advantages blacks could ever hope to benefit from by residing in the American North, and the white South has the proper understanding of the Negro's best interests. ${ }^{6}$

An article published February, 1956 titled, "Negro Progress Is Big Credit to White South,” provides a thorough defense of the benefits of southern segregation for the Negro reminiscent of antebellum, Old South, proslavery arguments. Blacks are better off, it is argued, in the South under the condition of racial segregation and, if understood in a longer historical context, one can appreciate how modern segregation and even pre-Civil War slavery liberated the Negro from his primitive social condition in Africa. Pushing back against civil rights activists and 
organizations who advocate on behalf of black freedom by way of eroding southern segregation laws, the article champions the virtues of racial separation by noting the educational achievements of southern Negroes through their exposure to white civilization in America. Blacks would therefore be doing themselves a disservice by taking inspiration from those who seek to challenge the traditional order of southern race relations. In showing how much the Negro has benefited from exposure to southern white culture, a comparison is drawn between impoverished inhabitants of the Third World, who would eagerly embrace the infinitely more advantageous opportunity to live in a society which, as is sarcastically suggested, supposedly discriminates against and persecutes the downtrodden Negro as the "race agitators" would have many to believe. Again, the main argument being made here is that the enjoyment of certain privileges not afforded the Negro in his native homeland abound in the American South. ${ }^{7}$

While some credit is given to Negroes themselves for their own advancement, the ultimate responsibility for black achievement, according to the Council, rests with "the patience and friendship of southern whites,” who in the aftermath of the Civil War aided the Negro out of the misery of illiteracy and economic dependency. In making this point, an article is cited from the Nation Magazine of September 4, 1954 entitled, "Up from Reconstruction."8 The title is noteworthy because it may strike some as reminiscent of Booker T. Washington's autobiography, Up from Slavery. Washington was the foremost post-Reconstruction black spokesman who advocated acquiescence to the segregated white power structure that dominated the lives of black people in the aftermath of emancipation from slavery. He embraced the politics of placating southern white anxieties over the possibility of mass Negro exodus out of the South as former slaves embraced their new found opportunities for participation in the wage-labor market. Along with exercising newly acquired political privileges, Negro exodus posed a real challenge to the stability of southern white rule. In his famous 1895 speech at the Cotton States Exposition in Atlanta, Washington made an appeal to white southern business leaders, presumably on behalf of 
the protection of the Negro’s best interests, to consider the loyalty of hard-working Negroes before thinking to hire newly arrived and unfamiliar foreigners. The Citizens' Council’s preference for the black leadership of Booker T. Washington is in fact made clear in a February 1958 piece titled “Who Will Lead The Negro?”, citing the virtues of his philosophy in contrast to that of Frederick Douglass. Washington, according to the Council, “...taught that people won their status in society by their service,” and in his leadership he, “...exemplified the spirit of humility." Frederick Douglass on the other hand, according to the Council, exhibited "the spirit of arrogance.” The historical lesson drawn from this comparison is applied to what was once the "great progress” made under the leadership of Washington, to the "militant, arrogant NAACP” which was "dominating the negro mind.",9

Prospects for Negro success are plentiful in a segregated society, as is claimed in the Council paper, and "Negro citizens are enjoying an increasingly higher standard of living in the South” because of the available educational opportunities. Therefore, “...the Southern Negro has much to be thankful for as a result of friendship and cooperation by his white friends.” Again, to reinforce the notion that southern blacks are better off in the context of Jim Crow segregation, the point is made that the condition of the American Negro must be contrasted with that of his African counterpart, and the savagery of that primitive land must be fully appreciated in order to come to a proper understanding of the natural social position for Negroes in American society. The message is particularly directed at those who advocate on behalf of blacks in their efforts for racial integration and racial equality. An excerpt from the article is quoted below and is not only an illustration of the Protection of the Negro’s Best Interest Frame, but also the overlapping, intersecting and interrelated Savage African/Savage Negro Frame, Historical Lessons Frame, and the Race Agitator Frame.

RACIAL AGITATORS would do well to study the history of the Negro race before demanding over-night miracles and unrealistic concessions. First and foremost, they need to discard the false notion that Negroes originally were a 
"free people reduced to slavery." Actually, they were merely transferred from cannibalistic enslavement by their own tribal chiefs in Africa to a relatively being [sic] enslaved in the Western hemisphere. Negroes brought as slaves to America were infinitely more fortunate than those who stayed behind. For countless centuries the Negro had the entire African continent at his disposal, yet no great cities were built there. No great books, newspaper or lasting contributions to culture, science and progress have ever come out of Africa, nor do Negroes own that country today or enjoy free rights there. Without white influence Africa would lapse into barbarism in a few decades. ${ }^{10}$

The conclusion in the above is clear. Civil rights activists with the support of the federal government are ignoring the overwhelming weight of evidence with regard to Africa's savage past, and are working against the natural order of mankind with regard to civilization. Blacks themselves would not even have the intellectual capacity to engage in such musings as agitating for the extension of democratic rights and privileges to themselves without having been liberated from the barbaric primitivism of their indigenous savage habitat of Africa. Negroes are therefore either unaware of the extent to which they have benefited from the white man's civilization, or are thoroughly ungrateful, or have altogether been corrupted by the twisted subversive logic of liberal-minded civil rights agitators who have to great effect, with the cooperation of the federal government, undermined what is essentially a beneficial social system for the Negro. The theme of Negro primitive savagery, as expressed in the form of sexual immorality, criminality, and disease is explored further in the next sub-cluster.

\subsection{B Sub-Cluster 2: Negro Depravity and Primitivism}

According to Citizens’ Council ideology, Negroes tend to exhibit various behavioral characteristics which fall outside the established norms of Christian morality. Out-of-wedlock, (or in the words of the Council, "illegitimate"), birth is a key illustration of Negro vice. It is no coincidence, as the Council suggests, the greatest statistical occurrences of this problem happen where Negroes are free from the necessary restraints of segregation and are granted the presumed blessings of liberal equalitarianism. Social experimentation in the big cities of the North have 
produced high rates of "bastard" children among the black populations there, having the unfortunate, but yet not unforeseen, consequence of unsupervised Negro youth engaging in the sort of criminal activities that terrorize whites who, for these reasons, maintain their own northern segregated neighborhoods. This, as the Council argues, highlights the central hypocrisy of northerners who preach against southern injustices while practicing their own forms of racial separation. This is also proof that northern whites are fully aware of the true character of the Negro, even as they or their political leaders, leftist academic thinkers and "moderate” preachers of "liberal theology," focus all their attention on supposed southern racial problems. This does nothing more than agitate Negroes to question the many great benefits southern whites have bestowed upon them. Indeed, as the Council saw it, the South afforded many opportunities for its black population; opportunities they are hard pressed to find in the believed-to-be integrationist utopia of the North.

The rhetoric of science and historical observation are often employed to support the idea that Negroes are unredeemable in their intellectual inferiority. In a January 1957 article entitled, "Refuting The Big Lie”, the supposed scientific observations on race by Pitirim Sorokin, Chairman of the Department of Sociology at Harvard University, are cited. Sorokin, as is asserted, aimed his theoretical insights at demonstrating the weaknesses of the psychological and sociological claims put forward by the NAACP in the Brown case. The argument being made in this article resembles that of Thomas Jefferson's views on race expressed in his Notes on the State of Virginia. In Jefferson's book, like this article, racial difference between whites and blacks is argued on the basis of what has been supposedly produced in history by the races. White intellectual superiority and Negro mental deficiency are inherent facts of nature as evident in the advanced civilization of the Caucasian race and the absence of any comparable level of sophistication on the part of the Negro race. According to the article, "in Africa they [Negro] had as many chances in the long course of history to create complex forms of culture as the white race 
had elsewhere and yet nothing has been created.” This idea is reinforced with a refutation of socalled "environmentalist" arguments of the day; that the unfavorable social condition of the Negro in America is responsible for their apparent inferiority in society. Instead, as is contended in the article, “...the environment of either the Russian peasantry before the annihilation of serfdom or of the medieval serfs, or of the Roman and the Greek slaves was probably not any better, if indeed it was not worse than the environment of the American negro before 1861 or at the present moment.” In contrast to the Negro, the Roman and Greek slaves “...in spite of their environment, yielded a considerable number of geniuses of the first degree,” while “...the American Negroes have not up to this time produced a single genius of great caliber.” The conclusion drawn from the apparent evidence presented in the article is that the inherent superior qualities of whites and inferior characteristics of blacks “...point at the factor of heredity, without which all these phenomena cannot be accounted for."11

In making the case for the view that Negroes are fundamentally depraved and uncivilized, the Council, in its official paper, presents numerous statistical evidence and reports on the unruly criminal tendencies of Northern blacks, especially violent acts including murder, but with great attention to Negro rape. The data on Negro vices, as assembled in the pages of the Council paper, emphasize the idea that setting the Negro free from the restraint of Southern style segregation, and foolishly granting him social equality is to invite anarchy which will replace good order and civil society. Southern whites are therefore the wiser for instituting what appears to be, from the perspective of the naïve Northern liberal, a brutal, unjust system of social control, but a necessary domesticating mechanism for those who, by virtue of their racial temperament, cannot govern themselves.

A February 1957 article titled, “Reaping The Whirlwind-Integration In Washington Creating Ominous Unrest,” is a great illustration of the Negro Depravity and Primitivism subcluster in the larger Negro and the Segregationist Imperative frame cluster. A number of points 
are made about the negative consequences of integrated public schools. First, the inherent intellectual inferiority of the Negro lowers the overall quality of education as adjustments are made to adapt the pre-existing academic environment to the mediocrity of black underachievement. The new integrated educational regime, in the eyes of the Council, apparently proves the natural distinctions between whites and blacks. Secondly, fundamental cultural differences between black and white educators complicate the educational process. Thirdly, the inherent predisposition of the Negro to various immoral behavioral characteristics breaks down the moral fabric of the school social environment. Noted among these undesirable Negro qualities are "venereal disease and pregnancies”, and according to data cited, “Approximately one fourth of the Negro school children themselves are illegitimate.” A fourth point made is that incidences of school violence have increased as a product of forcing races together, as stated in the article, "Interracial conflict has sometimes involved a degree of violence which is new and shocking to many white families.” The above issues noted, according to the Council, all point to the fundamentally flawed Court ordered and NAACP engineered social experiment in which both white and black children alike have been used as guinea pigs to prove some fanciful but dangerous liberal goal. ${ }^{12}$

A November 1956 article titled, “Scandal of The Century! Facts of “Nation’s Model Schools” Shock Americans,” illustrates how the various presumed questionable behavioral characteristics of blacks, if allowed free reign by the naive liberalism of integration, can work to undermine the proper functioning of the public school system. According to the article, there has been a suppression of "ugly facts...concerning conditions in Washington public schools since they were integrated...” In light of this, as noted in the article, the House District Sub-committee held a number of hearings which revealed the extent of chaos plaguing public schools in D.C. These hearings brought to light examples of 
...violence, truancy, malicious destruction of public property, and thievery among students; of shocking sex behavior, involving not only students, but also at least one Negro principal; of pregnant Negro school girls, including a 13-yearold who was "expecting” her second illegitimate child; of cheating on examinations by District Teachers College students... ${ }^{13}$

The conclusion is clear from the above excerpt. Negroes fundamentally lack the moral substance of whites and racial mixing in public schools in particular would contaminate the racially pure moral character of white people. Further illustration of this logic is in a March 1956 article titled, "Disease, Prison Records Reflect Lapse in Morals Poses Real Threat to the Welfare of Our Entire Nation.” Again, the idea here is that segregation acts as a check on unsavory Negro behavioral inclinations that, if left unrestrained, will have a deleterious impact on society. Evidence of the positive effect of segregation on Negro vices are the higher rates of various Negro social maladies in the un-segregated North, such as illegitimate births, violent crime and larger Negro prison populations, and increased incidence of venereal disease. By drawing attention to these inherent Negro social problems, the Council attempted to position itself as an organization concerned with public health and safety, and the maintenance of conformity to values that strengthen, not weaken the social fabric. In contrasting the chaos of the un-segregated North with the ostensible virtues of Southern society, the Council noted that,

Southern officials, both law and health, point to the moral restrictions inherent in segregation as the principal reason for the differences, and again remind us of the fact, so well known to Southern officials and seemingly ignored by our Northern neighbors, that the negro has such a strong proclivity for "mistaking liberty for license.”14

The Citizens' Council's anxiety over racial contamination through interracial sex was indeed a major concern, but it frequently overlapped and intersected with other fears of racial contact. The prevalence of the "Negro blood defect" of sickle cell anemia, for example, is often noted to provide further reason for the avoidance of interracial marriages. In a June 1958 article titled, "Bad Blood Can’t Fly,” the supposed findings of medical research make clear the dangers 
of the sickle cell trait which, according to the Council, are present even if it is not apparent that a Negro has the disease. Negro inferiority, as the article makes clear, is contained in the very blood of the Negro and is a transferrable contagion which therefore necessitates racial separation in medical practice. ${ }^{15} \mathrm{~A}$ February 1958 piece features a physician expressing concern over an announcement in a newspaper that Georgia lawmakers proposed interracial blood transfusions. This law, according to the doctor, could only have been thought up in the mind of "a damned yankee” integrationist. Apparently, as the doctor claimed, various elements in the Negro blood such as "sickle anaemia [sic]" can be a "child killer" and "can result in invalidism and shorten lives.”16

Another illustration of how the Council's anti-miscegenation views coincided with other fears of racial contamination is in an article titled, "Ten Cents per Lady.” This brief but to-thepoint piece, in very clever and subtle fashion, merges white outrage over the integration of public transportation with white anxiety of black men having sexual access to white women through the supposed federal government mandated subjection of white women to prostitution. By breaking down segregation on public transportation, according to the article, the government has permitted the Negro the unjust privilege to sit next to white women for a fee and therefore have sexual access to them. This access was previously unavailable under the necessary and proper system of racial segregation. By legalizing interracial interaction on public transportation, according to the article, "the Supreme Court has evaluated Southern womanhood at 10c per lady.” Through this "legalized atrocity,” the Court has therefore established "the price any colored man can pay for the right to sit next to a white lady on a bus."17

The theme of Negro primitivism is evident in the Council's multiple articles on the lynching of Emmett Till, and the role the NAACP played in the effort to seek justice in this infamous episode of racial violence. Till was a fourteen year old black boy from Chicago who was visiting his extended relatives in the town of Money, Mississippi and was brutally murdered 
for making flirtatious comments toward a white woman. The Citizens' Council featured a number of articles in its paper on this subject, singling out the NAACP in its effort to draw attention to the murder. In attempting to delegitimize the NAACP and its activism in light of the Emmett Till lynching controversy in Mississippi, a historical comparison is made between the tactics of the NAACP and the supposed traditional cultural practices of witch doctors in "African jungles long ago" in "the Congo.” Writer Thom Etheridge states that,

The Congo witch doctor was happiest when inciting his emotional followers to anger. Trouble was his business and he thrived on it. He loved the limelight and lost no opportunity to strut, talk big and throw his weight around. ${ }^{18}$

Another comparison is made between NAACP activists together with the mother of Emmett Till, putting on public display the mangled, tortured body of the lynched Emmett Till, and the primitive emotionalism of African ritualism. The author writes that,

When a fellow tribesman was slain by rivals, the witch doctor immediately sprang into action. He ordered the victims mangled body displayed for all to see. As infuriated tribesmen filed by, the dead one's family sobbed and moaned. Meanwhile the witch doctor screamed, raved and ranted. ${ }^{19}$

The article goes on to note the many "thousands of respectable Negroes" who were understandably upset but did not lose themselves to the savage passions of Congo witch doctor behavior. According to the writer, these "respectable” blacks did not engage in irrational actions that may have made matters worse. They kept their heads cool, in contrast to the Chicago event where Till's body was on display which the article editorializes must have been for the purpose of instigating violence against whites. The article describes the event where Till's body was on display as a "funeral frenzy," "deliberately contrived to further aggravate the situation in Mississippi,” and that law enforcement there failed in their duty to prevent such chaos. ${ }^{20}$

Another article on the subject of Emmett Till titled, “Life Magazine Can Quote Scripture For Own Purpose”, makes the assertion that Till was not really an innocent child, but was a 
"husky” teenager as evidenced in published photographs. According to the piece, Till was sexually mature enough in his age to direct aggressive flirtatious behavior towards white women, and that he had apparently "been with white women before.” Till’s inappropriate "advances alarmed Ms. Milam to the point of running to her car for a gun,” after he directed "an obscenity” at her. A larger explanation is provided in the article, noting that "All these things are part of the depressingly familiar pattern of Negro teenager behavior,” which plagues the big cities of the North. The idea that Till's murder was a tragedy is challenged in the article, suggesting instead that, “It was unfortunate that young Till didn’t keep his hands to himself. It was unfortunate that the case happened in Mississippi, favorite whipping boy of the liberals...” In contrast to any sympathy felt for the murdered Till, attention is drawn alternatively to the alleged epidemic of rampant violence visited upon white youths by black perpetrators in northern cities, reinforcing the notion of primitive Negro savagery. ${ }^{21}$

In a final example of the Negro Depravity and Primitivism sub-cluster, as illustrated in the Council’s interpretation of the Emmett Till murder, an April 1956 article titled, “Expose Another Giant Lie By New York’s Controlled Press,” aims to debunk certain myths about who Till really was by revealing the true immoral and wicked character of his father. According to the article, contrary to the claims of the heroic status of Till's father during his service in the U.S. Army by New York’s Life Magazine, Alabama Journal’s James K. Hatsell exposes the father as a disgraced murderous rapist who was executed by the U.S. Army for his crime. Till's father, it is claimed, “...had been hanged in Italy by the U.S. Army for wartime murder of two women and the rape of two others.” The point of this article was to discredit the brutally murdered Emmett Till who, apparently by his father's misdeeds, was not an innocent youth, but a young black boy no different than the common over-sexualized Negro male who is ever eager to test the limits of white authority by violating the presumed purity of white womanhood through savage rape. 
Emmett Till, is therefore not a victim, but in this light, a deserving recipient of necessary justice which functions more broadly to keep the barbaric passions of the Negro in check. ${ }^{22}$

The Negro and the Segregationist Imperative frame cluster from the perspective of the Citizens' Council’s official paper is summarized in the following. Set free from the necessary social system of racial separation, the Negro will have no self-restraint on his passions and will take sexual liberties with the innocence of white women. Negro immorality is especially evident in the numerous instances of un-wed Negro mothers and, in the words of the Council, "This is proof of the well-known fact that our negroes, as a race make a mockery of the white man's holy Institution of matrimony.” The truth of Negro inferiority is a "painful” reality, according to the Council, but the question must be asked, "How would Integration affect the moral standards of our white children?”23 The Council's answer is clear: The advancing tide of uncivilized Negroes flooding into white schools, and all other public spaces reserved exclusively for whites, must be stopped. The insidious activities of race-agitators must also cease, especially Communists and their sympathizers who are bent on disturbing southern tranquility by stirring up Negro passions against southern whites who wish nothing more than to see to the Negro’s best interests.

\subsection{Frame Cluster 2: Ideological Un-Americanism}

As a frame cluster, Ideological Un-Americanism, in terms of frame arguments, is not as dense as The Negro and the Segregationist Imperative. It is only composed of four primary frame arguments including, the Anti-Communist Frame, the Anti-Liberal Frame, the Anti-Left Frame and the Anti-Socialist Frame. It is fair to note the difficulty at times in distinguishing the terms Socialism/Socialists from Leftism/Leftists and Liberalism/Liberals as the Citizens' Council understood these political ideologies. Throughout the pages of the official paper these terms were often used interchangeably in the same articles. However, to reiterate, this is the nature of frame constellations, which are comprised of intersecting, overlapping and interrelated frame arguments. In general, what these political identifications had in common, from the point of view 
of the Council, was that they were essentially un-American ways of thinking that needed to be cleansed from the political culture and every other corner of American life. These notions, as pathways toward Communism, were regarded as antithetical beliefs to the religion of Americanism and therefore needed to be exorcised from the nation's soul before it had become fully possessed of Communism's true diabolical intent. What follows here is a discussion of each of the segregationist frame arguments which comprise the Ideological Un-Americanism frame cluster.

\subsection{A Ideological Un-Americanism and the Anti-Communist Frame}

According to the Citizens' Council, almost every major institution in the nation had seen some infection of the germ of ideological un-Americanism, from Churches, many of which betrayed Christian tradition by siding with racial liberalism, to educational institutions where young white boys and girls were being subject to the presumed dangers of socialistic experimentation in violation of the natural separation of the races, to America's political institutions and national government which were full of politicians and court justices who had done more damage than anyone to bring the country closer to the deadly embrace of Communism.

The Council liked to position itself as the opponent of un-American civil rights, civil liberties and labor organizations which it often categorized as "left-wing," "Socialist" and “Communist.” There are segments of the official paper where presumably sympathetic individuals were given column to express their support for the Council's struggle against the allied forces of ideological un-Americanism. One such person named Mrs. Francis P. Mims, editor of "The Councilor," the publication of the Association of Citizens' Councils of Louisiana, appeared as a guest editorialist and expressed the following.

These organizations, and many individuals who hate Citizens' Councils, usually hate everything else American. They are dedicated to the destruction of our form of government. They are determined to ruin us economically, weaken us morally 
and destroy our racial integrity. They would educate us to ideologies foreign to the traditions of our forefathers. They cynically do their dirty work under the banner of "democracy."24

The argument is clear. To hate the Citizens’ Council is to despise America. Christianity, capitalism, “racial integrity”, liberty, states' rights and constitutional government are the core characteristics the ideological forces of darkness are arrayed against. These diabolical entities yearn for a race-mongrelized, atheistic society where man lives not by his grit and hard work, but instead wallows in the mediocrity of equality where racial distinctions are ignored. According to the Council, if the liberal equalitarians, leftist utopians, and unrepentant Socialists had their way, the germ of Communism would take root in America and would be watered with the blood of innocent lives to bear the fruit of tyranny.

One may wonder, it is suggested in the Council paper, how it is that northerners are so hostile to, or at least do not take pride in the notion of a racially segregated society where whites control its institutions, as the Founding Fathers intended. The answer, according to the Council, is rooted in the extent to which Communism has infiltrated the American psyche. Communists understand that the Negro problem is the weakest link in the American democratic republic. It is therefore the greatest tool of exploitation to agitate the Negro and cause others to agitate on his behalf, bringing about in the cleverest of ways, the erosion of the very fabric of American society. Liberals fail to acknowledge this as fact, while leftists and Socialists have committed themselves to their un-American radicalism, all while the nation's political leaders care nothing for serving the interests of a society that is based on the notion of freedom. Instead, they would rather sell their souls in exchange for whatever the deceitful Communists promise them.

\subsection{B The Anti-Liberalism Frame}

In the wider society, as the Council saw it, key American institutions, such as the Church, academia, and labor unions, fall victim to Communism by way of a liberal-minded naïveté. 
Liberalism is a pervasive wishful-thinking which over-idealizes the world as one would desire it to be while ignoring the harsh reality of the natural order of things. This blissful mode of thought cannot or prefers not to see the truth; that everyone has their place in the pecking order of civilized society, and that certain races are fit for self-government, while others, by evidence of their own barbaric history, have time and again proven themselves to be unsuitable for the responsibility of stewardship over the civilized, free world. Liberalism, while not explicitly Communist, is a political philosophy in America that orients itself in ways that are sympathetic to Communist thinking. Liberalism is bent on correcting supposed wrongs in society through untested practices of social engineering, such as, and in particular, racially integrated schools. These social experiments ignore the basic truth of established tradition, violating all that is held sacred in society. Liberals develop their social theories in their sanitized academic laboratories, isolated from reality and thus flawed from inception. Common sense is not their guiding principle. Instead, they are driven by their arrogance and immature belief in the capacity of modern man to tinker with and alter nature itself. The central flaw of liberal ideology is its wishful idealism in its desire to shape existing social reality to an unrealistic utopian vision. This central logic of liberalism is what makes it particularly susceptible to the insidious nature of Communism. Having disdain for traditional values in society, liberals open themselves up to Communism's evils. If the silent majority sit idly by and fail to champion the cause of conservative principles, the Council often warned, this will allow the "do-gooder” liberals to lay the groundwork for eventual Communist takeover of the greatest and freest nation to ever exist, which will subsequently lead to the enslavement of the rest of the free world.

Liberalism, according to the Citizens' Council, is rooted not only in blissful idealism, but a kind of 'holier-than-thou' arrogance which seeks to shame that which it deems inferior to itself. The favorite target of liberal critics is the South, which serves as the canvas upon which they seek to paint their utopian vision. The arrogance of liberals is especially evident in their conviction that 
they even have the right to correct southern traditions, ignoring their own northern urban problems, to create a social condition for the Negro better than what the South had provided to that race since the nation's founding. The following excerpt from an article titled, "Segregation and Christian Love,” articulates the Council’s principal gripe with liberal politics.

The tragedy of America today is that the well-meaning liberal has been misled into believing that segregation is based on race hatred. When the misguided liberal realizes one simple thing-Segregation is not based on hate, it is based on Christian love - then will he begin to have some understanding of his conservative Southern neighbors and also some love. The only bias and prejudice that we have to worry about today in this country is the twisted and determined hate that northern reform liberals and their friends have for the men and women of the south. The Northern Liberal urge to remake the nature of their neighbors in their own image instead of loving their neighbors and respecting the differences is the ancient tragedy of great arrogance born of great ignorance. ${ }^{25}$

Reading the official paper of the Citizens' Council, one may see how early in the public debate the often stated defensive argument by conservatives that the term racist in American culture, has become a kind of knee-jerk, derogatory, "smear” label which liberals often use to discredit those who express certain politically incorrect views on racial issues. According to the Council, liberals are determined to shut down debate on controversial but important topics by trying to "smear" their conservative targets with the charge of racism. This liberal tactic, the presumably persecuted conservatives feel, has been employed promiscuously, and too such an intolerant point, or perhaps to a cunningly calculated degree, that the "real” racial problems plaguing black Americans are being ignored for the more salacious, and mainstream mediadriven, ritual of the public shaming of honest, good intentioned, "tell-it-like-it-is" conservativeminded individuals who are pressured into conforming to the liberal orthodoxy of political correctness. This liberal tactic, as the Council argues, is an effort to distract America from actual problems that impact Negroes, not white racism, but black underachievement, out-of-wedlock birth, black-on-black crime, and a host of other issues which blacks themselves are responsible 
for. But do not be distracted by the diversionary rhetorical schemes of liberals, the Council advises. Failing to recognize the danger in the liberal attempt to stifle free expression will inevitably lead to eventual Communist takeover of not only America's political culture, but the very minds of free peoples will be enslaved to the tyranny of conformism. An article titled,

““Racist’ A Smear Word,” illustrates the Council’s argument.

We have come to be afraid of a few smear words and terms, "Racist" is one of the worst. It is not defined so that the victim may disagree and defend himself. But it is so spat out, even in print, as accusation of some vicious crime placing the defendant beyond some pale. It presumes automatic condemnation without trial. But what is a "racist”? A “RACIST" IS A PERSON who approves his own race and prefers the society of his own people. Millions of human beings of all races, in fact, most of humanity, is "racist" by that definition. But the despised and persecuted "racist" meant by this propaganda is not condemned for his amiable preference, which implies no hostility to any other race. He is persecuted for showing the courage to express his preference in words and suiting his conduct to his words. He may express his preference in the most gentle, courteous and friendly language. But the mere expression is the crime of "racism." There is also false assumption now accepted as undebatable truth that all minorities are entitled to special immunity from fair criticism and fair opposition. The very word "minority” has come to denote a small, helpless and, above all, absolutely inoffensive, element of human being. But reason holds that a majority also may be virtuous. And majorities were massacred in Soviet Russia by a minority which did not bother to pretend that it was harmless. The Communists are still a small minority throughout the Soviet empire. Controversy is not dead in the United States, but it has been strangled into unconsciousness. That is bad for our intelligence, our character and our souls. ${ }^{26}$

The influence of liberalism, according to the Citizens’ Council, was also evident in American Churches, the one institution which presumably should have been most immune to the un-godly logic of equalitarianism. Disturbed by the expansion of "liberal theology," the Council aimed to correct the "misguided" actions of Christian clergy who failed to understand that their message of 'brotherly love' and other civil rights activism was “helping to betray our American Republic-and Christianity itself.” The following article thoroughly questions the loyalty of religious leadership for embracing integration, asking in the title, “Are Some Church Leaders 
Betraying Their Country?” Liberals and well-meaning social thinkers “have been deluded by red propaganda into believing that there is a "Christian Socialism” which would eliminate poverty and trouble and stabilize human happiness and prosperity.” Many leading Christian hierarchies have all been "duped" by "false prophets" who are "Unwittingly... working for the spread of Communism which is the deadly enemies of Christianity.” These foolish, naïve clergy have been "infected" with the virus of "socialistic theories" which run contrary to the laws of God and nature, and ignore the lessons of history with regard to the insidious nature of tyranny. ${ }^{27}$

\subsection{The Anti-Left Frame}

Left-wingers, as portrayed in the Council’s publication, are the more hard-edged version of liberals and are essentially no different in their desire to corrupt the political system to their nefarious goal to remake traditional America into a collectivist utopia. In their effort to weaken and ultimately destroy this white-centered Christian Republic, the leftists advocate policies which would break down barriers to race mongrelization and promote a society where all are treated equally and all can intermingle without regard to race differences. Left-wing activism, which is rooted in racial agitation, only seeks to bring about the dawn of a new race-mixing "Negrophile Dictatorship.”28

The Citizens' Council in its propaganda publication, aimed to expose the true left-wing plot to defile the purity of the white race by subverting the political system to the goal of interracial sex. In an article titled, "Fair Question,” the author is only identified as “A proAmerican” from Hillside, New Jersey, indicating the existence of like-minded pro-segregationist northerners. Contrary to their publicly stated claims of not being interested in interracial marriage, as is claimed in the article, leftist organizations, particularly the NAACP, are in fact "working in the exact opposite direction" in their state-by-state agenda to gradually repeal laws against the "vicious practice" of miscegenation. ${ }^{29}$ 
The Council makes a similar connection between leftists and interracial sex in an article titled, “Left-Wing History Prof Bares Goal of 'Do-Gooders', ” writing that, “the real goal of racemixing attempts in America is intermarriage, a left-wing historian told an Illinois audience this month.” The article takes particular issue with what is claimed to be the professors' misquoting of Abraham Lincoln when he made the point that the Great Emancipator would surely have been in agreement with the Supreme Court's striking down of segregation in public schools, and perhaps would have even endorsed racial integration in other spheres of American life. To expose the professors’ misunderstanding of the Civil War presidents’ views on race relations, “Lincoln’s own words on the subject," expressed in the famous Lincoln-Douglas debates, are printed. In 1858, in response to Senator Stephen Douglas who called into question his allegiance to white supremacy, Lincoln stated the following, as is presented in the article.

I will say then that I am not nor ever have been in favor of bringing about in any way the social and political equality of the white and black races-that I am not nor ever have been in favor of making voters or jurors of Negroes, nor of qualifying them to hold office, nor to intermarry with white people; and I will say in addition to this that there is a physical difference between the white and black races which I believe will forever forbid the two races living together on terms of social and political equality. ${ }^{30}$

In the above quote, the Citizens' Council functions as historical truth teller, correcting misguided or outright dishonest left-wing falsehoods and other hoopla, peddled by such intellectual "do-gooders" as the professor who was criticized in the article. Academia, from the standpoint of the Council, is a propaganda haven for leftists who are among the most insidious of individuals in America who use their exalted positions in institutions of higher learning to spread their un-American ideology. To illustrate the growing extent to which leftist ideas were taking root in the minds of America's impressionable youth the Council cited statistical figures indicating the left-ward drift. An article titled, “School Poll Has Socialist Trend,” provides an example. As often occurs in the Council's paper, the terms 'socialism' and 'left-wing' are used 
synonymously in this piece when making the case for the younger generations' seeming affinity for un-American ideological perspectives.

The shocking degree that left-wingers have infiltrated American education was revealed by a recent poll of 5,855 high school students by Scholastic Magazine. More than one-third of the girls and almost one-fourth of the boys favor Government-ownership of nine basic industries which are now privately owned. More than half of the girls favored government ownership of banks. Almost onefourth believe in Government ownership of the coal industry. A large majority felt that it is an advantage to belong to a labor union. ${ }^{31}$

\subsection{The Anti-Socialism Frame}

The Communist plan, as the Citizens' Council saw it, was to turn America into a Socialist country in order to make way for eventual takeover by Soviet Russia. Socialism is the Communist program for the reformation of society through social engineering by government bureaucrats who acquire their reformist logic from leftist academic elites. Socialists advocate for improvement of society not through free-market individualism, but through militaristic government coercion. When Socialism takes root in America, Communism will have reached its full maturity, ripe with the deadly fruit of totalitarianism. Socialism at its core, as the Council suggests, is full only of the bitterness of radicalism. It ever seeks to create the conditions for a society under one system of rule. The clever nature of Socialism is its subtle but infectious appeal to those whose state of mind is ever unsatisfied and ungrateful for the blessings of liberty as the Founding Fathers sacrificed for and instituted in our republic. Today, the government and wider political system at all levels is becoming infested with a small but growing influence that seeks to dismantle the pillars of society. As the Council explained it, “A radical, socialistic, even communistic minority seeks control of the government that they, by dictatorship, may dominate the American people and lead them into a socialistic world government.”32

Using the international media as an example of the infestation of Socialism in American institutions, the Council focused its criticisms on reporting of racial upheavals in Africa. The 
Council saw the international media as a propaganda platform for Socialist-Communist ideology in its supposed disproportionate coverage of the oppressed Negro, exploited proletariat and other disaffected groups. The international press, largely headquartered in the United States, is merely a mouthpiece for the un-American political establishment, especially the "USA's Democrats,” “a party very largely dominated and directed by persons of Eastern European origin,” who seem to be obsessed with dismantling white civilization, whether in the American South or in South Africa. All one had to do, according to the Council, was to observe the example of the Mao Mao Kenyan terrorists to see the results of Communist infiltration as a destabilizing influence on what was an otherwise perfectly functioning African nation previously under the stewardship of white rule. Africans, as examined in their own history, have a great aversion to civilization. The Negro in his natural habitat does not tend toward law and order. As Communism worked its way into the anti-colonial African independence movements, the savage dark heart of the Negro was set loose and a reign of terror prevailed. Citing the South African Observer in its assessment of racial problems in that country, the Council saw a similar struggle among white South Africans, but on a scale far greater because of that country’s significantly higher proportion of blacks in comparison to whites. Putting the racial conflict in terms of Cold War geopolitics and raising the specter of a tyrannical one-world government, the South African Observer is quoted by the Council as stating the following:

United Nations, UNESCO, the empires of Wall Street and Moscow and their dupes, viz. Internationalists, liberals, liberal-democrats and leftists generally, have marked out South Africa as an enemy because it is a bastion of white conservatism; because it believes in national sovereignty and western Christian civilization; and because it will not accept the Fabian, Socialist and Communist doctrine of Equality. ${ }^{33}$

Not limited to the media or the political establishment, it was also in the Church, the Council argued, where one could see the growing influence of Socialism, where modern ministers entertained novel theological notions that were divorced from traditional principles, making them 
open to the idea that Christianity and racial separation were incongruous. According to the Council, only socialistic thinking sees an incompatibility between Christianity and segregation. Christian principles as set forth in the Bible are unchanging. Man in his imperfection is subject to change and adaptation to schools of thought which are not in line with biblical teaching. According to the Council, "Our modern ministers have the Bible and Socialism, and for them segregation is incompatible with Christianity. The only difference is Socialism. The Bible hasn't changed, and, if Socialism is omitted, segregation and Christianity are still compatible.”34 Educational institutions were also in the Communist plan for the takeover of America through Socialism. The Council regarded federally mandated integrated public education as a “socialist school system.” Apparently private schools were increasingly becoming the preferred option for whites seeking refuge for their children to escape the "black-and-tan schools." 35 Institutions of higher learning were also falling under the influence of ideological unAmericanism where "students are uniformly indoctrinated in Socialist theory." To counter the nefarious encroachment of Socialism, the Council would suggest "Books Worth Reading." Among the list was a piece by F. Merrill Root entitled, “Collectivism on the Campus,” which warned of the susceptibility of college students to teachings which were anti-capitalist, antiindividualist and atheist. ${ }^{36}$

To counter the threat of Socialism, the Council urged its readers, especially "Women of the South,” to “Take Your Stand Now,” and direct activist efforts in several specific ways. First, the Council advised that concerned citizens can do their part by voting in favor of and electing into office those devoted to maintaining segregation at the local, state and federal levels. Secondly, the Council suggested one should avoid membership in, or contributing to integrationist organizations, and challenge the "false doctrines" being spewed in many churches and women's groups. Finally, it encouraged its readers to contribute to their local Citizens' Councils and add strength to the growing movement. ${ }^{37}$ 
From the perspective of the Citizens' Council, liberalism, leftism and Socialism all comprised an ideological spectrum which served as gate-way philosophies to the real geopolitical threat. Each represented a gradual step closer toward the true Communist menace. Liberalism was thought to be a well-intentioned but foolishly naïve idealism that individuals under the influence of which could still be rescued from if treated with a healthy dose of the realism of conservativeminded thinking. The hard-edged cynicism of leftist politics was more intellectually sophisticated however in the worship of academic elites. Taking inspiration from such thinkers such as Gunnar Myrdal and W.E.B Dubois, the hard-left was thought to be far more committed to its cause than “do-gooder" liberals. Those under the spell of Socialism, in the view of the Council, were perhaps too far gone and almost thoroughly indoctrinated, as Socialists had committed themselves to a political ideology that was fundamentally in opposition to free-market capitalism and therefore was anti-American. Socialism, in the spectrum of ideological un-Americanism, was the last stop on the way to Communism.

\subsection{Frame Cluster 3: Struggle for the Preservation of Freedom}

The following paragraphs are organized around the components of the third and final frame cluster: Struggle for the Preservation of Freedom. Under the Personal Freedoms Frame, there are three sub-frames: the Freedom of Association Frame, the Freedom of Choice Frame, and the Individual Liberties Frame. This frame cluster is structured around the notion of white freedom through the preservation of a racially segregated social order. The 'struggle' itself is defined by segregationist efforts to push back against government violations of white peoples’ constitutional prerogatives to have freedom of choice in their rejection of racial integration and racial equality; to be free from federal coercion to interact with those seen as unfit to enjoy the full benefits of democracy. 


\subsection{A Personal Freedoms Frame}

From the perspective of the Citizens' Council and its segregationist devotees, freedom is an idea woven into the very fabric of America's governing system and is a thing to be enjoyed only by those fit for self-rule. Freedom is a creation of the white man and could only have been brought into existence by white people. Free society, and the principles which guide its proper functioning, exist for the exclusive benefit of white people, and no other inferior race. The United States of America, as the Council makes clear, "Is The Land of Freedom," where "White People Like To Be Free,” as it has been since the founding of the nation. Since the Founders themselves “...could not make their rules in the country they came from,” as the King in England denied them to do so, "White men built the United States so they could make their own rules."38 Though freedom was asserted by the Council to be the unique desire of white Americans, the organization also wanted to emphasize that a particular geographic area of America was responsible for giving birth to the white man's freedom in the nation, and that the most notable of Founding Fathers himself, was originally from that special freedom-loving region. The Council writes that,

George Washington came from the South. He was a Southerner just like you. He was so brave and honest the people asked him to be President. So he was our first President. Now you know where our first President came from. He came from the South. ${ }^{39}$

In the pages of its official paper, the Council made a great effort to foster southern nationalism and patriotic affinity for America through the unique southern cultural contribution to the development of a free, white land. To give southern pro-segregationists nationalistic inspiration the Council provided brief paragraph-by-paragraph historical assertions in its recurring piece called, “A Manual for Southerners.” One particular historical claim made is explained under the sub-heading, "SOUTH LED THE WAY TO FREEDOM,” which argues that, “Southern men took the lead to win freedom for America against England.” Downplaying its economic, political and social significance, the subject of slavery is directly addressed towards 
the end of the "Manual for Southerners," under the two sub-headings, "America Forced to Buy Slaves” and “America Never Liked Slavery.” England is blamed for the introduction of slavery into America. King George, it is asserted, desired for English merchants to become wealthy and therefore, "the Americans were made to buy the Negro slaves.” Though Americans presumably despised slavery, “they did not want to set black men free among them.” To do so would violate the fact that "God made them different." The piece finally ends by pointing out that "Russia Has White Slaves Today,” and that "most of the slaves in Russia are white people.” This final point is almost certainly an anti-Communist frame argument meant to push back against Communist critiques of the racial oppression of blacks in America, the South in particular. ${ }^{40}$

\subsection{B Freedom of Association Frame}

As God created the races different from one another by color, ability and preference for one’s own kind, the Council believed, these differences should not be violated through coercion by government militancy against people's freedoms. For when the government forces integration on the races it is not only an abomination of nature, but an affront to what God created as right and just. As the Council put it, "When man works to destroy these God-given distinctions he opposes part of God's plan.” Segregation by race, in the eyes of the Council, is not a mere political matter for man to interfere with, and if integrationists thrust such an unnatural thing upon citizens against their free will to associate with the likeness of their own kind, this can only lead to misery for all races. As the Council put it,

Bayonets build no brotherhood and rifle-butts cannot knock love into the heart. To follow the pattern of normal affinity is not racial discrimination but rather normal determination. Voluntary association of these races, while preserving their distinctions, is the normal pattern of a related world, but forced associations destroy the quality of existence. ${ }^{41}$

Americans as far outside the South as Nevada, according to the Council, recognized the federal government's violation of citizens' freedom of association by race, and there was no 
better patriot and honorable American to articulate the grievance of a loss of freedoms than a soldier who had fought for his country. As a twenty-five-year-old veteran apparently recalled,

I was told in school about my freedoms as an American. No one told me then that I had to go to school with a Negro, whether I wanted to or not. Would someone please tell me how a group of men known as the Supreme Court can now tell me and the other free people of a free country what persons we must attend school with, like it or not? ${ }^{42}$

In Citizens’ Council ideology, government mandated racial integration is a violation of the rights and freedoms of citizens, particularly white Americans. As part of the struggle against tyrannical authoritarianism for the preservation of freedom of association, the Council would cite instances of progress in favor of their cause. Celebrating the decision of the Washington State Supreme Court in an article titled, “White Rights Upheld,” Judge Joseph A. Mallery is noted for his effort to expose "Negroes of trying to deprive whites of the right to choose their associates in private affairs.” Apparently the judge made a public statement to support the invalidation of a state civil rights statute which the Council found worthy of printing in their official paper. "A victorious crusade of the NAACP,” Judge Mallery is quoted as stating, “for the special privilege of Negroes to intrude upon white people and their private affairs can only be won at the expense of the traditional freedom of personal association which has always characterized the free world."43

\subsection{Freedom of Choice Frame}

The struggle to preserve freedom of choice in America, as the Council framed it, should not be mistaken for a fight that is confined to the South. Even the big cities of the urban North are facing a growing threat to the right to choose to be free from racial integration. "Leftist pressure groups,” especially the NAACP, are aiming their sights at northern communities in which they seek to institute local ordinances that would abolish the rights of whites to live with and among whomever they choose. However, northern whites are waking up to the antagonizing antics of the 
NAACP. Occasionally, the Council noted, white northerners are venting their frustrations in the form of "violent public reaction.” Signaling the coming of white flight if the integrationists have their way in the North, the Council quoted the New York Real Estate Board as stating that, “...many residents of the city, conscious of their constitutional right to live as they choose, will move out of the city rather than submit to the force of law in sharing apartment houses." While the Council would often point out instances of northern white sympathy for the cause of segregation, they simultaneously criticized the white North, especially major media outlets like the New York Times for "tak[ing] the hypocritical position that coercion should not be used except in Dixie."44

Championing the cause of the freedom of choice, the Council also warned that, “...the basic inalienable right of the individual to do as he pleases with his private property is now being challenged before the US Supreme Court.” In this particular instance, the freedom of a "white homeowner" was being threatened as the Court considered whether he should be "forced to sell his home to a Negro.” This was an issue which the Council reasoned should not have even come before a court because of the obvious constitutional right of whites to choose what to do with their own private property. Apparently, as the Council worried about how the Supreme Court would render a final decision on the matter, the organization took the time to note the like-minded prior judicial interpretation of the Washington State Supreme Court which ruled in favor of the white homeowner. In detailing the origins of the case, the Council cited the opinion of Judge James W. Hodson's words below.

We are faced here with a head-on collision between two rights, both of which historically have been regarded as basic, natural, inherent and inalienable. One is the right of every individual to be treated equally, regardless of such irrelevant factors as race, creed and color. The other is the right of the owner of private property to complete freedom of choice in selecting those with whom you will deal. ${ }^{45}$ 


\subsection{Individual Liberties Frame}

Individual liberties, as the Council asserted, were being eroded by the rising tide of an alliance between needy Negroes and do-gooder liberals. Individual rights were claimed to be under threat from the growing political influence of special interest, race organizations pressuring weak-kneed politicians into compromising on constitutional principles in order to satiate the Negro appetite for more and more of what the white man has earned with his own hands. The Negro, it was alleged, manipulates the sympathies of bleeding-heart liberal reformers who cannot help but see only what social ills need to be remedied in America. What results from this nefarious relationship between shiftless, ungrateful Negroes and their left-wing white northern Angels, is a diminution of the status and rights of hard-working white Americans. In light of this menace, the Council cast itself as the heroic defender of the rights of the individual. Since blacks had the NAACP to agitate on behalf of integrationists and Negro grievances, as the Council saw it, so too must white people have an organization to defend segregation and protect individual liberties.

To broaden the scope and significance of its cause, the Council would sometimes include in its defense of individual freedoms, “...the actual liberties of all the people, white and colored in the North as well as in the South. ${ }^{\text {46 }}$ The real target of the Council, in this light then, was not the downtrodden Negro, but instead the federal government usurpation of constitutional authority through the violation of personal rights of all Americans. For example, civil rights reforms intended to change hiring practices which were deemed racially discriminatory in denying minorities fair employment opportunities, were seen by the Council as illegitimate legislation existing only for the purpose of "stam[ping] out American liberty and freedom of action.” Such policies were not truly designed to promote fair practices in employment decisions, but rather were the product of “A Police State.”47 
As an illustration of the Council's concern with the perceived threat of racial integration in the workplace through hiring practice reforms, a protest letter, apparently written by white airline employees, was featured in an article in the official paper which equated integration with a loss of white freedoms. By “accepting Negroes as flight crew members,” the statement of protest reads, “...a violation of individual rights of white workers would be involved.” Racial integration and equality, as understood by the authors of the protest document, could only come at the expense of white people's liberties. To merely share the same space with blacks was an affront to white freedoms because such an arrangement would not be consented to by whites but instead would be “involuntary social contact among crew members.” Elevation of Negro workers to the equal status of white employees was akin to a violation of the freedom of conscience for white people. As is stated in the article,

That the Negro might be denied work open to whites is unfortunately possible, but if the Negro's theoretical right to a given position must be won at the cost of discomfort, inconvenience and distress of the white working majority, then, this is not a right but a violation of rights. ${ }^{48}$

Legislation aimed at rectifying racial disparities were targeted by the Citizens' Council as evidence of a violation of the rights of white Americans. Through the federal government, a “Dictatorship of the Bureaucrats” threatened the sanctity of individual liberty and other variations on the notion of private rights. ${ }^{49}$ Personal freedoms, as the Citizens' Council declared it was in a struggle to preserve, could only be maintained by way of free association between individuals who choose to interact socially on their own terms. Forced social interaction is an artificiality orchestrated by those who wish to subject liberty to the designs of social engineers. Government cannot create by force, the desire to integrate if the urge to do so does not first dwell within the hearts of its subjects. Therefore, whites uninterested in being subject to newfound notions of what is deemed best for the Negro by their supposed advocates should not and shall not be deprived of 
their inalienable freedom to engage in the traditional and reasonable practice of maintaining race purity through racial separation.

\section{CONCLUSION}

This chapter provided a qualitative analysis of the first of three major pieces of empirical data for a concept proposed in the previous chapter. As the intellectual architecture of a movement's cosmology, the frame constellation is the entire interlocking web of collective action frame arguments as defined by core movement ideology. Its structure is comprised of multiple frame clusters which are regional assemblages in the constellation of frame arguments organized around a central subject as related to the movement's ideological nucleus. Within frame cluster local configurations are sub-clusters, which are relatively smaller numbers of tightly interconnected frame arguments structuring the larger frame cluster theme as related to the grand movement ideology. Frame arguments then, become the basic unit of a movement's ideological thrust, which, in the case of the Citizens' Council, is white supremacy. White supremacist ideology, as reflected in the pages of the Council's official paper, is composed of three major frame clusters: first, The Negro and the Segregationist Imperative (which includes two frame subclusters: 1) Racial Symbiosis, and 2) Negro Depravity and Primitivism; secondly Ideological UnAmericanism; and finally Struggle for the Preservation of Freedom. The next chapter continues with the frame constellation concept as applied to the Citizens' Council’s broadcast media propaganda campaign. 
CHAPTER IV: CITIZENS’ COUNCILS OF AMERICA BROADCAST MEDIA (1955-1966)

\section{OVERVIEW OF THE CITIZENS’ COUNCIL BROADCAST MEDIA}

As the organizational manifestation of resistance to what it framed as a fundamental existential threat to modern, civilized society, the Citizens' Council represented the vanguard in an epic struggle for the preservation of the traditional racial hierarchy in America. As with the official paper and the magazine that followed, the Citizens' Council Forum served as a media platform from which segregationists could amplify their voices in the contentious national dialogue over the expansion of equal rights to blacks. The Councils' broadcast media, in contrast to the official paper, is a relatively more generic and watered-down presentation of the organization's agenda to oppose integration and racial equality. As propaganda literature, the official paper is considerably denser in its diversity of race-related topics covered, though all point towards a general white supremacist and pro-segregationist perspective like the Forum. The official paper is dripping wet with blatant, vicious racism, whereas the Forum programs (taking into consideration the pre-politically correct era in which all of this occurred), are comparatively more subtle and polished for wider public consumption.

One thing is absolutely clear about the Forum broadcast program however, antiCommunist framing is the most dominant theme in the cosmology of Citizens' Council ideology. From the perspective of the films alone, the Council is primarily an anti-Communist organization dedicated to foreign-policy critiques from a white southern pro-segregationist point of view. A sizeable portion (to be quantified in the concluding chapter), of the entire series of programs focuses on foreign-policy discussions, especially on the significance of the threat of global Communism. Many of the guests on the Council's Forum engage in an entirely exclusive discussion of Cold War geopolitics, much of which is focused on a critique of the supposed weaknesses of U.S. policy toward Cuba, North Korea, Vietnam, and the Soviet Union's Communist network in general, at times with very little, if any, mention of civil rights or race 
relations in U.S. domestic context. From the perspective of various prominent anti-Communists featured as discussion guests, Communists seem to be an ever present apparition everywhere and nowhere simultaneously, relentlessly working to undermine the pillars of American democracy through highly sophisticated plans that only the most vigilant mind can be aware of. Even ultrapatriotic conservatives, as expressed in one Forum program, may themselves fall victim to the clever tactics of Communists though they may hate them. ${ }^{50}$ Though many Forum segments feature political figures, academics, and even foreign dignitaries who express explicitly antiCommunist views, one must keep in mind however, that segregationists did not necessarily separate current events within the United States from international affairs as related to Communism.

The Council's Forum was organized into fifteen minute, weekly programs consisting primarily of interviews that were produced and hosted by Dick Morphew. Exceptions to this general format include special feature documentaries produced by other organizations and media outlets covering subject matter which the Council saw as relevant to its target audience and that coincided with its ideology. The vast majority of Forum shows, however, began with the white southern nationalistic theme song, "Dixie,” briefly interrupted by the voice of William J. Simmons who gave the introduction stating, "This is the Citizens' Council Forum, the American viewpoint with a southern accent presented by the Citizens' Councils of America on behalf of affiliated state organizations throughout the South.” Returning back temporarily to the triumphant patriotic sounding chorus of the theme music, Simmons' voice then continues with the following.

The Citizens' Councils are dedicated to states' rights and racial integrity, to individual liberty and to race relations based on common sense, not on the power politics of left-wing pressure groups. The Citizens' Councils are primarily a means of mobilizing public opinion. Informed people will not surrender their freedom. Now from Washington, here is your host for Citizens' Council Forum, Dick Morphew. 
Thus begins the Forum, as host Morphew welcomes the audience to the show and then introduces the featured guest or guests. After the main portion of the program, the Forum often concludes with another theme song, which is again interrupted by the voice of Simmons who states the following.

This Forum has been presented by the Citizens' Councils of America. We Americans are threatened with the loss of many of our hard-won freedoms; the historic right of each sovereign state to govern itself without interference from political courts, the right of the individual to choose his own associates without the prodding of federal bayonets, and the right of each citizen to make up his own mind in the American way, free from alien propaganda. Each of us has a job to do. Your support is needed. For information, write: Citizens' Council, Jackson, Mississippi. We will be happy to send you, without obligation, copies of our literature showing how you can help. Just write: Citizens' Council, Jackson Mississippi. The South is organizing. Join with those who stand publicly, fearlessly and determined that these freedoms will be maintained.

Since the Forum series exhibits a clear and dominant theme of the threat of global Communism, perhaps a helpful method of classification is to distinguish those programs that deal with the subject of Communism in international context first, from that of Communism's relationship to more domestic matters second, and finally from those which focus primarily on segregationist issues but with anti-Communist framing as a more subtle background theme. The first section provides an in-depth qualitative overview of the Citizens' Council's anti-Communist agenda in global geopolitical context as exhibited in its Forum broadcast propaganda media effort. The second section focuses on critiques of U.S. foreign policy by anti-Communist guests, followed by a discussion of American segregationist support for global white rule and the subservience of black Africans against the destabilizing force of international Communism's perceived nefarious role in anti-colonial independence movements. In the fourth section, the chapter shifts to Forum commentators who concerned themselves with Communist subversion and its related ideologies with the United States, particularly with the civil rights movement and infiltration into America's political establishment, as evidenced by the presumably anti-American 
civil rights legislation produced by Congress, supported by the Supreme Court in its controversial rulings, and subsequently enforced, often in dramatic ways through the use of federal troops, by the White House. For segregationists, the ground-zero for deep-rooted Communist infiltration seemed to reside in Washington D.C. through the unholy alliance between spineless politicians and "minority pressure groups" seeking underserved goodies from liberal politicians. The fifth section continues much of what is addressed in the previous segment but narrows the discussion more on the notion of the loss of American freedoms, particularly as related to threats to freedom of association, freedom of choice, restrictions on use of private property. All of these types of jeopardized freedoms point to the loss of individual liberties for white Americans. The chapter then delves deeply into the politics of segregationist scientists and their effort to expose the scientific truth about racial difference against the perceived dogmatic, left-wing mainstream, environmentalist, equalitarian view as allied with the racial integration movement. The final qualitative discussion in this chapter highlights selected programs designated here as "special cases” because of their distinction from more unified themes presented earlier in the discussion, followed by the conclusion.

Concepts introduced in the previous chapter will also be applied here, as hinted in the above chapter outline, though not necessarily in the same order or as structured a manner. To reiterate, this research conceptualizes the Citizens' Council’s frame constellation as organized around a core of white supremacist ideology, which is composed of three major frame clusters: first, The Negro and the Segregationist Imperative (which includes two frame sub-clusters: 1) Racial Symbiosis, and 2) Negro Depravity and Primitivism; secondly Ideological UnAmericanism; and finally Struggle for the Preservation of Freedom.

\section{COLD WAR ANTI-COMMUNISM OF THE CCA BROADCAST MEDIA}

As noted in the introductory chapter, social movement scholars have missed the great depths to which southern segregationists, especially at the level of grassroots organizations, had a 
sophisticated long historical view of the perceived menace of global Communism, a keen awareness of contemporary world events and their ultimate relationship to southern regional concerns over civil rights protests. As previously stated, the major thrust of the Citizens' Council Forum films is that of anti-Communist geopolitics and the threat of ideological un-Americanism within the United States. For example, a documentary presented by Pepperdine College, shown on the Council’s Forum program titled, “Communism and Coexistence,” provides a rather lengthy and detailed history of the origins of Cold War geopolitical state of affairs, charting the development of Communistic movements throughout the world, noting that, "The Russian people were the first victims of Communistic tyranny.” Alexander Kerensky, former president of the Democratic Provisional Government of Russia, who was overthrown by Communists in 1917, gave the introduction to the film, the thrust of which emphasizes a central idea: Lenin's original concept of "coexistence” must not be misunderstood for its true nefarious intent against the West. According to the video, "coexistence” is the idea that a Communist republic cannot exist in a capitalist global context but must vanquish capitalism once the Communist republic is strong enough to do so. One must not therefore, mistake Communist peace overtures for genuine, sincere efforts to share the world with capitalism. ${ }^{51}$

In the film, Vladimir Lenin is credited as the father of Communism who laid the foundations for spreading that ideology across the globe, while Nikita Khrushchev, leader of Russia at the time of the videos' production, is noted as following the ideology of Vladimir Lenin and the notion of “coexistence.” After the death of Lenin, Stalin continued the Russian dictatorship under his authority and on the backs of minority groups used as slave laborers, and marked clergy and religion as the enemy of the Communist state. As portrayed in the documentary, Communists engage in deceitful talk of peace as they pile up armaments and continue to advance their revolution. Communists are duplicitous and only seek to uproot and overturn the bedrock of tradition, stifle the flowering of free society, and secure their foothold in 
Eastern Europe and Asia. The spread of the Communist revolutionary struggle is the process by which the world gradually becomes enslaved to Marxist-Leninist tyranny which can only be unraveled by Western military might. ${ }^{52}$

In another Pepperdine College documentary titled, “Communist Accent on Youth,” the focus is again on international Communism, where various incidents of social unrest around the world have their ultimate origin in a Soviet global conspiracy. As stated in the introduction to the video, Americans face a choice between two ideologies, Socialist-Communism, which is characterized by total power over the individual within the state; or democratic capitalism, which advocates for a people's government that grants to the individual certain rights and freedoms. Forty percent of the world's population, as is claimed, had fallen under Socialist-Communist control. The narrator asks how this could happen, which transitions from the introduction to the actual documentary portion of the video.

The main focus in the film is on various global youth protest movements, including students in San Francisco “led by known Communists.” The president of Pepperdine College states that, "this is not a propaganda program” but rather is a factual presentation of how Soviet Socialist-Communism plans to divide and conquer the world through seizing on social turmoil like student riots. As noted, various geographic sites of political unrest inspired by Soviet Communism include, Cuba, France, Yugoslavia, and even within the United States itself where in New York City, black civil rights activists are shown clashing with local law enforcement just outside the United Nations. These episodes of student youth demonstrations, according to the president of Pepperdine College, are completely emotional as opposed to rational.

On the whole, “Communist Accent on Youth" is an attempt to discredit student protest movements as absurd and the product of ungoverned human passions. Wild-sounding drums are provided as background music perhaps to suggest the feeling of primitivism and savagery for the soundtrack of Communist-inspired anarchy as manifest in unruly student demonstrations. Black 
civil rights activists are shown in confrontation with the police, as the narrator continues to explain the Leninist philosophy and the Communist goal for global domination. The film provides a lengthy account of how Soviet tyranny spread throughout various parts of the world, citing instances of insurgent uprisings against Communist domination, only to be crushed. “Communist Accent on Youth” is a very serious and sophisticated presentation of what is understood to be the significance of the Communist threat in international affairs, where youthful idealism becomes the means by which Communists can agitate and exploit fissures in the fragile fabric of free and open societies such as the United States. ${ }^{53}$ The next section continues the Council's international perspective on Communism through criticisms of U.S. foreign policy by Forum guests.

\subsection{Anti-Communist Foreign Policy Critiques on the Citizens' Council Forum}

As in domestic matters, many featured Forum guests advanced a local control perspective that deemphasized the federal government's reach into certain issues which, it was believed, individuals closer to the particular problem at hand should oversee. Accordingly, military leadership, as Strom Thurmond often argued, should be granted greater discretion in strategic matters. Local commanders on the battlefields of Vietnam, in particular, Thurmond explained, should be granted full leeway in the selection of targets; a bombing strategy that would discourage "Red China” from entering the war. For example, as Thurmond elaborated, American Air Force pilots were required to submit a list of targets two weeks in advance before engaging the enemy which made no sense to military commanders who better understood the changing dynamics of warfare. An aggressive overwhelming bombing campaign against America’s enemies in Vietnam would ultimately help prevent the United States from getting entangled in a more costly and expensive ground warfare involving Communist China. ${ }^{54}$

Civilian leadership, in Thurmond's view, existed only for the purpose of setting policy parameters and defining the goal. As an illustration of his observation that Washington D.C. 
politicians were incompetent in the art of war, Thurmond would often cite the debacle in Korea which resulted in a military stalemate. If General MacArthur, the senator explained, had been permitted to pursue a winning strategy in Korea, the outcome perhaps would have been much more favorable to U.S. interests in that region of the world. ${ }^{55}$ He contended that America's failure to win decisively against North Korea was attributable to the policy decisions of certain political leaders who "believed in international Socialism," and who "do not wish to see a defeat of Communism.” Communism and Socialism, Thurmond explained, “are blood brothers.”56

For Senator Thurmond, the same wrong-headed decisions were being made in Vietnam. He particularly criticized Robert McNamara as not being a military expert and therefore should not have been intimately involved in putting limits on the strategic military decisions of commanders, especially the selection of targets and the types of weapons and tactics employed in order to win the war. ${ }^{57}$ Thurmond was also critical of U.S. equivocation on denying China admission to the United Nations and was not in favor of making compromise with a nation that he regarded as one of the main instigators of military hostilities in Vietnam, undermining American interests there. China, according to Thurmond, shared the same interests as the Soviet Union "to dominate and enslave the world.” U.S. indecisiveness as exhibited in the United Nations against China, or previously in North Korea, or the failure to win the war in Vietnam, according to the senator, would produce endless unresolved conflict in the world, which America's soldiers would be subject to generation after generation. ${ }^{58}$

Thurmond was especially irritated with the State Department for its policy of “appeasement” or what he called a "no-win policy,” and he wanted to clean out the agency of all individuals who subscribed to the ideology of international Socialism and who did not believe in winning once the United States entered a military conflict. Thurmond however, still remained firm in his support for President Johnson but he did feel not enough military power was being used in key strategic areas which would bring the war to a certain conclusion. Placating 
Communists with a policy of appeasement, according to the statesman, would only help to facilitate their global effort to enslave the world. ${ }^{59}$

Another frequently recurring Forum guest was Major General Edwin A. Walker who, as commander of the Twenty-Fourth Infantry Division level in Germany, was relieved of his duties and subsequently resigned because he believed troops were not receiving proper indoctrination. A Senate investigation into the muzzling of military leaders followed Walker's resignation. A speech by the General was featured in a Citizens' Council Forum production called, “Project: Understanding” with the program title: “The General They Couldn’t Muzzle.” As is claimed in the introduction to the film, Walker's address was made before an audience of nearly five thousand in a Jackson, Mississippi city auditorium. In attendance were civic leaders and political dignitaries, including Governor Ross Barnett, Mississippi Congressman John Bell Williams, and Arkansas Congressman Dale Alford. Citizens' Council cameramen were also in attendance to film the event. Walker began his speech before the pro-segregationist audience by celebrating Mississippi for its resolve against the forces of anti-Americanism and stated that Mississippi was, "the most lied about state in the Union". 60

Mississippi is a state, and greatest in its stand for freedom. To Mississippi goes much of the credit for the preservation of the Union. In standing for its own sovereignty Mississippi has defended the sovereignty of all. The Communists are afraid of you. They distract or obstruct you in the power of your state sovereignty and your great unity of purpose. They're aware of your leadership and of you as a symbol not only in the South but to the cause of freedom everywhere. The atheist enemies recognize the power of a deeply religious state and of men armed with the Bible and Christian faith. Here they find you armed not only in the church but in your homes with a weapon they will never defeat. I stand firm in the gospel of Christ. If he be with us, who can be against us, except Satan and the atheist Communist conspiracy allied with him. ${ }^{61}$

General Walker wanted to issue a warning to the Mississippi audience that beginning in 1933, “we have perpetrated and perpetuated a Frankenstein monster, three decades of Potomac pretenders, New Dealers, Fair Dealers, red herrings, coexistent artists, and U.N. one-world New 
Frontiersmen have conspired in the liquidation of our constitutional government by, for and of the people.” Walker explained that his departure from the military was out of his allegiance to America and not the "pretenders” who were undermining national sovereignty who were not interested in putting America first.

Walker claimed to witness overseas the insidious subversive activities of Communists seeking to destroy freedom, and he used the example of the Korean War debacle to illustrate America's failure to resolve itself to stand up against Communist aggression in the world. What the General learned in Korea was the inconsistency in foreign-policy against Communists and the parallels in American domestic policy. General Walker reminded the audience that the nation was at war and that the Bible and their Christian faith was their greatest weapon to defeat the "reds and pinks in every land.” He added that the Supreme Court was captured by the left in the United States and was being used as an instrument to institute un-American laws over the country. Congress too, according to Walker, though not yet under complete control of subversive elements in America, still had politicians within it who did not display unmitigated allegiance to American democracy. ${ }^{62}$

Walker was especially critical of the United Nations as presumably an institution for the promotion of peace but instead, he explained, functioned as an instrument to facilitate the spread of Communism by maintaining an immoral relationship with the Soviet Union. Walker advocated for Congress to investigate corruption in U.S. foreign relations. Leftist intellectuals were imposing their will on the Congress, he contended, and a policy of internationalism and peaceful cooperation were threats to America’s sovereignty. In citing the reasons for his resignation, Walker stated that, “As for myself, I could no longer serve in uniform, and be a collaborator with this release of our sovereignty to the United Nations.”63

Walker apparently developed a program called “Code Blue” and was criticized by the Overseas Weekly and by others for expressing extreme anti-Communist views similar to the John 
Birch Society. According to Walker, America's troops and general public were unaware of the threat the Communist enemy presented to the country as evident in military difficulties in Korea. Americans were not prepared for "fourth dimensional psychological cold warfare" as he explained. More importantly, a "no-win policy," or a "retreat from victory" posture on the part of policy-makers, had prevented the American armed forces from success in combat as the Korean War case proved. In contrast to America’s political leaders who continued to advance this failed “no-win policy,” Walker noted that the general American public was not in favor of “appeasement," and that the U.S. could not "coexist” on the battlefield with the enemy. While America’s political leaders engaged in peace talks, Walker explained, the enemy was repositioning itself to a more strategic advantageous posture. ${ }^{64}$

Communist subversion in Latin America was also of particular concern to many Forum guest commentators. Representative Armistead Selden, Democrat from Alabama and Chairman of the House-Sub-committee on Inter-American Affairs, appeared on a program to discuss the strategic and economic importance of the Panama Canal Zone for the United States. He described an incident of Panamanians attacking American nationals and attributed it to undemocratic ruling elites in Panama, stirring up nationalism against Americans. According to Selden, the United States, under the Eisenhower administration, bore some responsibilities for eroding its own sovereignty and creating difficulties when Americans made concessions to a Panamanian "mob of pressure” and “mob riots,” which ultimately was a product of Communist agents operating in Cuba. Hostilities orchestrated in Havana against the United States were apparent when the Castro government cut off the water supply to the U.S. Guantánamo base on the island. In light of this and other Communists antics in Latin America, the representative suggested the Organization of American States together with the United States, band together to stop Communist subversion and infiltration. ${ }^{65}$ 
In another Forum program, featured guest Representative August E. Johansen, ranking member on the House Un-American Activities Committee, made the observation that the general American public seemed to be well ahead of its political leaders on challenges to the United States faced by Cuba and the Soviet Union. Corruption, lack of courage and character, all pointed to the failure of America's political leaders in foreign-policy matters. Johansen also wanted to emphasize that the Eisenhower administration had not taken the Communist threat seriously enough with regard to their activities in Cuba and the wider Latin American region. Recognition of, and calls for a more robust foreign-policy approach to international affairs was not a partisan matter, but many in Congress, he explained, saw the need for a more forthright and assertive posture in the face of Soviet militarization, espionage and subversion on the island of Cuba. In fact, the representative expressed the view that in Cuba, "liberation by military invasion will be necessary, or may be necessary, and if necessary, should be pursued.” Despite Khrushchev’s threats of nuclear war according to Johansen, America's political leaders must not allow the United States to be under the threat of "nuclear blackmail.” If the United States continued to carry out the progressive policy of appeasement and surrender, it would surely enter war; whereas if America's political leaders instead adopted a firm position against Communist aggression, this would be the surest way to avoid military conflict. ${ }^{66}$

\section{Dr. Medford Evans was former chief of security training for the Atomic Energy} Commission and later became a consultant for the Citizens' Council, and appeared on a Forum program to discuss what he described as the Communist "one-world” vision of anti-colonialism and anti-white ideology. He first gave his interpretation of George Kennan’s articulation of what eventually became the U.S. containment policy of Communism, and criticized it as ineffective in dealing with the expansive nature of Communism to violently perpetuate itself throughout the globe. Dr. Evans then expressed the opinion that it would take a "believable threat of force" for the Soviet Union to withdraw from its Cuban military base, and that the United States would have 
to create a sincere threat in the minds of the Soviets that it would go to war; and that this would be the only way to get the Communists out of Cuba.

Evans cited two primary objectives of Communists in the United States. The first goal was complete military disarmament of America, particularly with regard to nuclear weapons; and the second was the goal of racial integration as related to anti-colonial movements in Asia, Africa and Latin America. Evans advised that America could win if it decided that it was going to meet the threat head on and "reach a decision that Communism must be exterminated as an active force in the world.” After being prompted by host Morphew’s question, he also noted that the American people were largely in support of confronting the global challenge of Communism, but that the people had lost interest in expressing disappointment with politicians such as Nixon, who had softened their anti-Communist stance once securing their political position. ${ }^{67}$

As illustrated in the above selected examples, southern white segregationists who appeared as guests on the Citizens' Council's Forum demonstrated a sophisticated understanding of issues beyond the regional racial unrest that characterized the civil rights era. AntiCommunism was the cutting edge of their perspective on global affairs. However, to paint a more accurate portrait of their foreign policy one must include a discussion of white supremacist ideology not as tangential, but as central to the segregationist anti-Communist worldview. This is addressed in the next section.

\subsection{Defense of Global White Rule against Communist Racial Anarchy}

As introduced in the previous chapter, the segregationist cosmology included a frame cluster concept referred to in this research as, The Negro and the Segregationist Imperative. This frame cluster is defined by the notion that racial separation is a necessity for historical, religious and scientific reasons, but was more critically important with regard to larger geopolitical, especially anti-Communist-Cold War imperatives. This frame cluster is divided into two subclusters: 1) Racial Symbiosis and 2) Negro Depravity and Primitivism. To reiterate what was 
elaborated in the previous chapter, the primary narrative-logic to Racial Symbiosis is as follows: If left unto itself, southern segregation functions as a harmonious, mutually beneficial system of racial reciprocation, uplifting the Negro to the extent that his nature allows, while facilitating the imperatives of modern society (white man's civilization), as manifest in the South. The principle idea to Negro Depravity and Primitivism is as follows: The inherent inferiority of the Negro, especially morally and intellectually, as a result of his savage, primitive nature, necessitates the imposition of an elaborate mechanism of social control (segregation).

The application of the logic described above was not limited to what segregationists understood as the "Southern way of Life," but was part of a larger global white supremacist vision of the "natural order of things" as related to the tension between barbarism and civilization. Not only did the American Negro need to be tamed by the necessary restraint of segregation, but so too did his more savage, primitive, dark relative in Africa, who had not been exposed to the presumed benefits of white civilization to the degree blacks in the United States had been since the time of their enslavement, followed by their circumscribed "freedom” under Jim Crow segregation. Southern white segregationists saw their struggle against the growing black menace as part of a larger struggle to maintain white control over the unruly Negro, especially in the emerging former colonial African republics. Lurking in the midst of it all, seeking to unravel global stability as maintained under white stewardship, were agents of the Soviet Empire. The Citizens' Council, however, saw itself as the champion of global white rule against the evil designs of Communists.

Proof that the reach of the Councils’ propaganda machine was international in scope exists in Forum programs which featured sympathetic, like-minded foreigners as guests who saw the need to make the case for the preservation of global white rule as the surest way to stem the advancing tide of Communist anarchy. For example, Ian Smith, Prime Minister of Rhodesia, was the guest for a discussion about sanctions that Great Britain and the United States, under the 
Johnson administration, had placed on the government of Rhodesia. This program was titled, "A Conversation with Ian Smith," the purpose for which host Morphew stated was to, "provide you with the information you need to form your own opinion about a part of the world which is all too frequently misunderstood by most Americans.”

Morphew provided narration for the first half the program, noting that it was on November 11, 1965 that Rhodesia proclaimed its independence, with Ian Smith as Prime Minister, and Great Britain subsequently refusing to recognize its sovereignty together with the instituting of sanctions against the new government. Morphew also pointed out that the American public remained uninformed about the global significance of Rhodesia and he followed up with various facts about the nation including its geographic and population size, natural resources and its economic independence, noting that it had never received foreign aid from the United States. Citing the significance of the arrival of the white man into Rhodesia seventy-five years prior to the air date of the program, Morphew stated that when the white pioneers arrived in the 1890s they, "found an untamed land, sparsely settled by sprinkling of African tribes." Similar to the Republic of South Africa, he continued, “Rhodesia’s black population increased as white settlers arrived to provide jobs and medical care and protection from intertribal warfare.” Summing up its significance, Morphew noted that Rhodesia, “accepted the challenge of bridging the gulf between the Stone Age and the twentieth century in the shortest time span that is humanly possible,” and that all of this was the result of seventy-five years of cooperation between European settlers and African natives, a goal that both white and black Rhodesians had been working towards. ${ }^{68}$

In the second half of the program, William J. Simmons, editor of the monthly Council magazine, The Citizen, toured the country and met with Prime Minister Ian Smith to get his view of Rhodesia's state of affairs. The Prime Minister contrasted the forty-some-odd years of responsible Rhodesian government with other African nations prematurely granted independence. Smith also commented on Britain's unsupportive relationship with Rhodesia and suggested that it 
was perhaps engaging in subversive activities which effectively undermined the U.S. effort against Communists in Vietnam. However, Prime Minister Smith contended, Britain maintained trade relations with Rhodesia when it suited its strategic purposes. Companies that are "openly associated with Communist Russia” still receive support from British and American economic dealings, he stated. In framing a question for the Prime Minister, interviewer Simmons stated that there was a "policy of favoritism" on the part of Britain and the U.S. toward hostile African nations to Rhodesia’s north, which were “dominated by black governments.” Smith did not want to hold the United States responsible, but he did accuse Britain, through its misguided policy actions, of being the primary culprit in creating the geopolitical conditions for Communists to engage in subversive antics in Africa against Rhodesia. The Prime Minister stated that, "the practical effect of Britain’s policy today,” was that it was “...aiding and abetting the march of Communism on the African continent.” After Simmons asked Mr. Smith about the future direction of his country, the Prime Minister clarified that he was, "not one of these people who sees a Communist behind every bush...” but that those who ignored the global threat of Communism, particularly on the African continent, “can’t see very far...”69

In another Forum program, set to the colorful, up-tempo and optimistic soundtrack of jazz music, a documentary titled, “This is Rhodesia,” details the founding of that nation under Cecil Rhodes. When European settlers arrived there, as the narrator explains, “They found a desert land riddled with disease and bent on self-destruction.” The indigenous people there, who were previously occupied with nothing but senseless war, had their way of life changed for the better by the pioneers who "brought medicine, law and order." In the video, a bustling modern city life is contrasted with the rural agricultural habits of the more traditional indigenous inhabitants, a scene which the narrator describes as, "a land of opposites where the old yields to the new;” adding that, “The opponents of change must move on.” The agricultural and mining industries are touted as one of Rhodesia's prominent economic vitalities, and the country is 
described as a "paradise” because of its balance between tropical heat and geographic height, making it the ideal climate for the new nation. The natural wildlife of Rhodesia is also described, especially as something to be valued and preserved. The narrator states that, “The Europeans' technology is benefiting all," and that the nation had rapidly advanced out of primitivism making the natives "the second highest [wage-earners] on the continent." Also celebrated are the educational and health institutions, cited as "second only to South Africa’s.” The narrator makes the point that, the European "has brought a country from the Stone Age to the atomic age in seventy-five years;” an "unparalleled achievement.” The Europeans are therefore, as is claimed in the video, not the oppressor of the African. Instead, the "European is his best hope for the future." The Negro in Rhodesia, it is concluded, “...will share with his white co-citizens all the amenities of a modern state." ${ }^{70}$

On another Forum show with the Reverend D.F.B. DeBere of South Africa as one of the guests, host Morphew began by asking for a clarification his responsibilities and whether this included dealing with evils of Communism, which the Reverend confirmed. Morphew also asked the reverend to comment on disinformation about the situation in South Africa, particularly the racial question, to which he replied that the reporting of facts in South Africa was "unilateral and very slanted.” DeBere did not believe that the American people were being properly informed of the truth of South Africa's situation and that news coverage of events there was swaying the public in a negative direction against South Africa.

Morphew contrasted America’s relatively small black population of approximately ten percent and ninety percent white to South Africa’s apparently larger race problem with a black population of eighty percent. The reverend confirmed and stated that, "Yes, I think we've got the greatest race problem in the world.” DeBere described the indigenous Bantu tribes there as being, “in different stages of civilization,” whereas the "mixed race” populations of half a million “colored people” who have "adopted the civilization of the white man,” are "very intelligent.” He 
also noted a third group consisting of the Indians which also numbered half a million, and he reiterated that South Africa had the most complex racial problem in the world.

Democratic representative from Philadelphia, Congressman Arthur Winstead, was also a guest on the program and wanted Reverend DeBere to elaborate on how the various races of South Africa felt about their country's segregation policy. Referring to it as the "the policy of separate development," the DeBere described the characterization of South Africa's segregation policy by the American and British press as being very "slanted," and "very incorrect.” He explained that, "by separate development we understand the differential development of each indigenous race in South Africa to its fullest extent and for the service of its own people, and according to the innate characteristics of each race." Seeking clarification, Morphew asked, "So in other words, you are not attempting to forcibly impose the culture of one racial group upon another racial group?” The reverend answered with, “No, we avoid that. We want to encourage each group to be proud of its heritage and its culture. We want to develop that according to its own culture.”

Reverend DeBere went on to describe the various educational institutions which presumably promoted the learning of various indigenous languages by the respective tribal groups in order to promote "full-fledged, free people.” Morphew asked whether local self-government was in the hands of indigenous people there, to which the DeBere replied by noting a 1951 law stipulating that the native people of South Africa would acquire self-government in their own territories, including four-hundred local and regional territories. He then spoke at length about the structure of governmental territorial authority which was organized in such a way as to encourage the eventual independence of these various territories. In answering the question of why so little was known about the separate development policies in South Africa, the reverend pointed out that, "the truth was being withheld," and that the media was selectively reporting "only the news the press wants the people to hear.” To counter this distasteful media coverage, the DeBere 
mentioned that festivities had occurred in areas where tribal chiefs wanted to send a special message to the government to express gratitude for what had been done for the Bantu people with regard to "education, hospitalization and for the right of self-government," and that they were “perfectly satisfied,” but that the public only hears about agitators stirring up trouble in the cities. $^{71}$

In another Forum program with Mississippi Democrat, Congressman John Bell Williams as the guest, host Morphew began the discussion by bringing up Williams' address before the House of Representatives regarding the United Nations, where the congressman asserted that, "the United Nations has become a racist organization.” The newly emerging African and Asian nations, which he described as "tribes" dominating the United Nations, operated only to interfere with the internal affairs of U.N. member nations. Representative Williams explained that, “in each instance the policy of the United Nations has been to support the colored races where they have come in conflict with the white races no matter whether the colored race was right or wrong in its position.” Morphew continued to read from the transcribed address of Williams stating that, the "United Nations has become a racist organization fostering racial strife on a worldwide scale.” Williams also argued that the U.S. bore its share of responsibility by supporting the U.N. in its supposed racial favoritism policy toward “colored nations;” countries which Morphew referred to as being populated with "primitive and backward peoples.” Williams also added that these nations consisted of "nothing more than tribes or clans," and that these "barbaric uncivilized” people “just haven’t reached the point where they are capable of governing themselves.” The congressman continued asserting that, even "the most flaming liberals" in America also agreed that many of the so-called "tribes” were "not capable of self-government." Morphew added that, “.... and yet we are supporting self-government at the expense of the white people who happen to be living in Africa."72 
Morphew also wondered whether it was idealism on the part of foreign-policy experts or whether politics explained U.S. support for the U.N. in its apparent preferential policy for anticolonial movements. Representative Williams did not readily accept the notion of idealism, but instead suggested that, "a great deal of this enthusiasm for these newly emerging nations as opposed to the white civilization, is based on a naked bid for the Negro vote in the United States.” The colored vote in America was related to the promotion of colored movements abroad, as Morphew added to the discussion. Morphew also wondered whether black people in America identified themselves with black people in Africa, and although Williams did not think that the average African-American was very much concerned with affairs over in Africa, he did state that, "the radical Negro press in the United States has lined the future of the African Negro with the future of the American Negro and is doing the best it can to continue to agitate this kind of strife.” Both Morphew and Williams also wondered about the relative ignorance of the American public to what they regarded as a nefarious U.S. policy toward international colored movements against whites. They noted however, that if the American public did become aware of the matter there would be a demand for a U.S. departure from the U.N., or a change in its policy. ${ }^{73}$

Morphew also asked about the up-rising of Angolan tribes against the Portuguese in the Congo and episodes of interracial violence, and why the U.S. government did not speak up against this sort of racial violence. Representative Williams answered that the United States government was afraid that it would "lose the support of the colored vote" if government officials spoke out against black uprising against whites in the Congo. Morphew and the congressman observed a double standard on the matter of racial equality with regard to promoting integration of the races in America but "supporting racist governments and policies in Africa.” Williams stated that, "those in power are seeing to it that the white race in Africa is held in a position of subservience.” Williams advocated for the U.S. to make an exit from the U.N. or international 
skirmishes of racial conflict would, he believed, "eventually sap the United States to the point where Communists will be able to take us over without too much of a struggle.”74

As illustrated in the examples of Forum programs described above, the Citizens' Council did indeed show an acute interest in foreign affairs as related to the thrust of their worldview. The segregationist cosmology must be situated in a Cold War context where the specter of Communism is ever present; where Soviet subversives are relentlessly working to orchestrate a reversion back to the primitive savagery of black anarchy on the African continent against Western civilizers there. Through international institutions such as the United Nations, and even through the perversion of U.S. agencies of foreign relations such as the State Department, Communist sympathizers busy themselves with the task of unraveling white hierarchies across the globe by stoking the flames of Negro tribal passions. This is the context in which to understand how segregationists came to regard their troubles within the United States against the tide of civil rights activism and reform; as a struggle for the survival of civilization itself. The next section turns to a more domestic focus of segregationist anti-Communism in the Council's broadcast media.

\subsection{The Threat of Ideological Un-Americanism}

As introduced in the previous chapter, Ideological Un-Americanism is a frame cluster which regards any philosophical pathway toward Communism as essentially un-American and therefore worthy of eradication from the landscape of America's political culture. As in the official paper, the Citizens' Council Forum was significantly preoccupied with identifying the various related political philosophies and radical activist habits that comprised the spectrum of ideological un-Americanism. For the Council, integrationist equalitarianism was the evil spawn of Communistic thinking, and was advocated by unapologetic Socialists, agitated for by hardcore leftists, and foolishly promoted by naive "bleeding heart" liberals. As stated by frequent Forum guest, Myers G. Loman of Cincinnati, Ohio, who was the Executive Secretary of Circuit Riders 
Incorporated, “To the liberal there is no satisfactory effective anti-Communism...” Host Morphew had asked Loman to address critics of anti-Communists, to which Loman replied by issuing a challenge to liberals to come up with an effective method of anti-Communism provided they were indeed sincerely concerned with the threat of Communism in America. ${ }^{75}$

Communists were engaged in a psychological warfare effort, as Loman expressed in another Forum program, and their infiltration into America's institutions, especially churches, as well as the proliferation of Socialist publications, were all part of a culture of "anti-American activities.” When asked by host Morphew about America's churches and their particular vulnerability to Communist subversion, Loman stated that American’s religious institutions “need to have an affirmative duty to have an anti-Communist program," especially those places of worship which have embraced the "race grievance” protestations of various civil rights organizations which Communists seek to exploit. ${ }^{76}$ Explaining his particular interest in Communist conspiratorial designs on America's churches in yet another Forum program, Loman discussed various major Christian denominational sects, providing apparent documented evidence proving that Communists were indeed infiltrating major religious institutions in the United States. After Morphew asked about the method by which Communist organizations formed and for what purpose, Loman asserted that Communists exist for the specific goal of "neutralizing the United States against a preparation for war,” or for more specific activities such as providing legal aid to individuals in America convicted of Communism. The Southern Conference Educational Fund (SCEF), Loman explained, may supposedly exist to address racial issues, but it was in fact a “Communist front advancing the cause of the Communist apparatus.” Loman added that the SCEF “... has probably exploited the race problem, the race grievance through the South as effectively as any other group in America.” When Morphew asked about the notion that these connections were merely coincidence, Loman answered, 
Well, when coincidence becomes a pattern it is evidence. There've been many persons hanged or electrocuted for...[sic]... on the basis of circumstantial evidence. Educated persons can hardly claim that making a career of out of being duped, that's ten, twenty or fifty or two-hundred times is coincidence; there's too much of a pattern there and that doesn't mean they're Communist, but at least they're making a career out of being duped. ${ }^{77}$

In another Forum program with Loman as the guest, he delved deeper into the details of the SCEF's Communist associations in what Morphew described as, "the current wave of racial demonstrations and agitations throughout the nation.” Although the SCEF was presumably created to pursue a civil rights agenda, in reality, as the Forum commentators claimed, it was founded for the purpose of advancing the cause of Communism. SCEF President Fred L. Shuttlesworth, as noted by Loman, was involved in "race incitation meetings all over the United States,” along with Executive Director, Reverend James A. Dombrowski, who apparently had a record of activism so radical that it did not matter whether or not he was actually a Communist. Loman also named Carl Braden, who was convicted in Kentucky for sedition and again in a federal court for contempt at anti-Communist hearings investigating his political identification. Lowman clarified that the named individuals were not "deliberately aiding the Communist apparatus," but indeed were aiding the cause of Communism, whether they were aware of it or not. Loman and Morphew repeatedly pointed to the inconsistency in self-identification of the individuals mentioned, some apparently going by different names in different regions of the United States to carry out their civil rights activism, while simultaneously existing in a perpetual state of denial about either their obvious Communist affiliations, or being a Communist themselves. ${ }^{78}$

In another Forum program with Representative John Bell Williams and Myers G. Loman both as guests, host Morphew once again asked about Communist subversion in civil rights protests. Representative Williams began the discussion by pointing to a photograph of Martin Luther King Jr. in attendance at a "Communist training school” in Highlander, Tennessee. Loman 
validated the authenticity of the picture which he claimed was evidenced by the photographers' testimony under oath that he indeed took the photographic images. Loman then took the time to identify persons featured in the photo, naming among other individuals, Martin Luther King Jr., Aubrey Williams, Myles Horton and Rosa Parks. Abner W. Barry was identified as, “a member of the National Committee of the Communist Party.” Aubrey Williams was also identified as having been a Communist for at least “two decades.” Loman also mentioned that trade union activists had been ejected from the AFL-CIO because of their Communist ties, and were also involved in training the individuals featured in the image at the Highlander "Communist training school.” When asked by Morphew whether a comparison could be made between protest tactics of labor leaders in the 1930s and civil rights activists, Loman made the following clarification.

First, in order that nobody, either Negro or white, will misunderstand any one of the three of us, we are not speaking in a derogatory way about Negroes per se. We are all three talking about Negroes who wittingly or unwittingly become used in the exploitations of the Communists and some of the hypocrites in our country for incitation purposes. ${ }^{79}$

Loman continued to explain how Communists exploit race grievances and asserted that the NAACP was the most infiltrated organization by Communists and that a struggle was going on within the organization to keep Communists from taking it over. Representative Williams also pointed to the clear and certain Communist identification of W.E.B. Dubois. Morphew asked whether there was anything typical about the sort of demonstrations occurring in the streets, to which representative Williams replied that, "If anarchy is typical of America, this is typical of America, but if adherence and obedience to the law and order is typical of America, street demonstrations certainly are not typical of America, and I think they ought to be deplored."

The previously mentioned Strom Thurmond, as a frequent Forum guest, often discussed the connection between Communism and the civil rights movement. Communists, according to 
the senator, aimed to create discord among the American people through their teach-ins among students, which had their nefarious connections to struggles overseas as the U.S. carried out military operations in South East Asia and in parts of Africa. If America failed to address the threat in these foreign lands, according to Thurmond, "Before you know it, they'll reach Hawaii." ${ }^{81}$ But Communists were already operating within the United States, as Thurmond himself would often elaborate on. Evidence of their subversive activities could especially be observed in the racial crises of the North's big cities. According to Thurmond, there was much more racial discord in the North than in the South and these problems had been "inspired by outsiders." Communists, according to the senator, infiltrated, inspired and directed "Negro demonstrations.” Thurmond explained that,

There have been many more riots and many more demonstrations and much more racial agitation and discord and dissension and trouble between the races in the North than there ever have been in the South. The people in the South have had no racial trouble except that which has been inspired by outsiders, chiefly. In the North it's a different situation. It spread from within the states, and as I have stated on many occasions, the Communists not have only have infiltrated these demonstrations but they have inspired these demonstrations and in many cases have directed these demonstrations. Communism is at the bottom of the Negro demonstrations. ${ }^{82}$

Morphew emphasized that most of the racial unrest in the South has been brought in by “outside agitators,” and that “imported agitators” were stirring up trouble in northern race relations. Thurmond also noted the parallels and similarities in Negro civil rights activism in the North and in the South, having a clear connection in his mind to a Communist conspiracy to direct Negroes to engage in unruly demonstrations. ${ }^{83}$

Taking aim at the political establishment, Thurmond also expressed his displeasure with legislative efforts at civil rights reforms, arguing that the public accommodations and housing civil rights bills being passed would not have impact on the realities of northern segregation. Despite the passage of civil rights legislation Thurmond argued, segregation persists in the North 
and will not be stopped. Instead, politicians are more concerned with currying favor with Negro voters in order to advance themselves. Political attempts to legislate racial harmony as Thurmond explained, “...will be repealed because it’s not practical, it’s not wise, it doesn’t make common sense and it will not have public support.” The lesson that should be learned from this, according to Thurmond, is that the passage of civil rights laws will do nothing to stop racial troubles, and it is nothing more than the "Negro vote" that politicians are after. To add strength to Thurmond's argument, Morphew read an article featuring quotes from prominent politicians suggesting that southern segregationists perhaps had it correct in light of the racial chaos taking place in the North; that northern whites appeared to be less tolerant of the imposition of civil rights laws and that a "white backlash" was beginning to emerge. ${ }^{84}$

In discussing the larger civil rights movement and the question of how revolutionary it actually was, as Morphew framed, Thurmond observed that, "they wish to supplant democracy and capitalism with dictatorship and socialism.” Emphasizing the grave significance of the Communist-Socialist, radical threat, Thurmond predicted that if the American people did not become alerted to and act upon this menace, that the president of the United States, "within twenty years would almost have the powers of a dictator.” The passage of the civil rights bill, and other similar legislation, according to Thurmond, concentrated too much power in Washington D.C., and, he exclaimed, “The greatest enemy of mankind, has not been mankind, it’s been government."

In a Forum program that more directly addressed the supposed excesses of liberalism and leftist activism in America, the featured guest was Joseph McDowell Mitchell, who was the field director for the Maryland and Virginia Citizens’ Councils in 1961. Mitchell, according to host Morphew, was subjected to attacks by "left wing and minority pressure groups," when he took a look into welfare policies in the United States. His job as field director was to go out and promote the Councils’ philosophy of "states' rights and racial integrity,” and to encourage unity between 
like-minded individuals in a defense against "liberals”, “agitators” and "insurrectionists.” Leftwing groups, according to Mitchell, were going into relatively peaceful communities where, "both sides are happy with the way things are" and, in the aftermath of their activism, "leave a trail of chaos behind them." He described the activities of civil rights organizations as, "fake demonstrations and trumped up marches,” and that the Councils were there to promote responsible activism and oppose violence, and were not interested in demonstrations but instead were for the maintenance of order, whereas the other side was interested only in "civil insurrection.” As Morphew emphasized, and as Mitchell agreed, one could travel just about anywhere in America and look hard enough to “find somebody who was unhappy;” individuals which Mitchell described as, "freaks and goofballs," who look "emaciated and they have beards" and are the "fringe scum of society." 86

Interestingly, on the question of whether or not Communism was at the root of all this, Mitchell was not sure. In Washington D.C., Mitchell observed upon his visit that there were federal personnel who might be sincere but were essentially misguided, and who by their sheer numbers, made the general area more liberal. The purpose of the Citizens' Councils, Mitchell explained, was to represent the majority of those who were not as boisterous and loud as the minority liberals in Washington D.C. He also observed that in the North there was a greater severity of racial problems. Both the host and the guest observed that the desegregation of public facilities put to a referendum vote would certainly reflect the majority of the people's will in their preference for a status quo on race relations and that the politicians were, by contrast, behaving in a manner that reflected what they imagined to be the public's true feelings on racial matters. ${ }^{87}$

Major General Edwin A. Walker, as noted earlier, also saw the federal government’s apparent embrace of the integrationist civil rights agenda as part of a larger compromise and appeasement philosophy, which stemmed from America's failure to understand the "fourth dimension” or psychological aspect of the war against global Communism. Walkers' 
understanding of the Cold War struggle was one where there was no such thing as a neutral position; "you're either on one side or the other," and the American side consisted of people who were lovers of freedom. Discussing the 1957 Little Rock, Arkansas controversy in the context of states' rights and state sovereignty, Walker interpreted events there as part of what he called, "subversive operations.” He believed that it was unconstitutional to send troops into Arkansas, that the troops were not needed, and if even they were this should only come under the governor's authority, and that because there was no request on the part of the governor of Arkansas for federal troops, this was unconstitutional. Noting his experience in Little Rock as the commander of the Arkansas military district, he explained that the federal government's civil rights efforts there were aimed at an overall plan and national policy to "break down states' boundaries," denying the governor there his constitutional right of authority over his state. Walker was convinced that the use of federal troops to enforce a desegregation order in 1957 under President Eisenhower was "part of a subversive operation against the state of Arkansas." ${ }^{88}$ Federal military assistance in state matters came only by the request of a governor and not by the usurpation of state sovereignty by Washington D.C., as Walker reiterated. He mentioned his resignation after his experience in Arkansas which he believed was, "tied in with Communist and Cold War activities throughout the nation,” and his frustration over the failure of American troops to be properly indoctrinated according to his geopolitical understanding of the domestic ramifications of Communist subversion. ${ }^{89}$

Edward Hunter, who was described as having served as a consultant to the Pentagon and to the House Un-American Activities Committee, was another regular guest on the Council's Forum. Hunter's main professional preoccupation, it was noted, was educating the general public about the dangers of the brainwashing techniques of Communists. He strongly urged that one must be explicitly and expressly anti-Communist in their orientation, and wanted to draw attention to the political pressure on anti-Communists themselves, warning that there is an "anti- 
anti-Communist” movement taking place in the United States. Noting the authenticity of the grassroots anti-Communist movement in America, which according to Hunter, the government dismissed as extremists, he described the most damaging attacks against anti-Communists as not coming from Communists themselves but from "anti-anti-communists" who have "taken their cue from the Communist unknowingly.” Particularly prominent were liberals who unwittingly aided Communists in their criticism of anti-Communists. As Hunter stated, "it would not be a mistake to say that he [the liberal] is doing a work for Communism that the Communist himself would not be in a position to do.” Hunter warned that those in positions of authority and influence in America should maintain vigilance and avoid falling into the clever traps of Communist subversion. Morphew asked Hunter to comment on the average business person in America who was largely unconcerned with the politics of anti-Communism, to which Edward Hunter replied that an awakening was indeed occurring among America's businessmen who also bore responsibility to pay attention to the seriousness of the Communist threat, or the collapse of the free market system and America itself would follow. Political and media elites in America, Hunter noted, in their vociferous criticisms of anti-Communists, cooperated in a wicked plan to destroy the United States. ${ }^{90}$

Hunter saw it as his duty to facilitate the dissemination of anti-Communist information and equip individuals with the proper "know-how" in order to "avoid falling into the booby traps which the Communists set to divide one American against another American.” Hunter’s organization, he explained, existed to help the various organizations within the anti-Communist grassroots movements establish their own information effort against the threat in America. Both Morphew and Hunter wanted to emphasize local control within the anti-Communist grassroots movement in America. ${ }^{91}$ After being asked about the status of the movement by Morphew in another Forum program, Hunter expressed optimism about educating the American public to the dangers of Communism so that it might eventually be defeated. He explained that regardless of 
party affiliation, the majority of Americans were in favor of taking a decidedly anti-Communist posture. According to Hunter, the anti-Communist grassroots movement was seeing an expansion. He did however; express the view that the weakness of the anti-Communist side of the American political spectrum was rooted in a mentality of defeatism. Hunter noted that the proliferation of grassroots movements was evidence of further Communist infiltration into American life. ${ }^{92}$

Host Morphew, in another Forum discussion, asked about various incidents of violence in America which Hunter described as, "part of a pattern, a pattern of indoctrination in this country that you might call dialogue or no-win, it’s a deadly pattern.” According to Hunter, there was a “propaganda climate” of "anti-anti-Communist” politics which produced the tragic outcome of the murder of eight student nurses in Chicago, whom were killed by one man. Hunter asserted that the man, with a knife and a pistol as weapons, was clearly aiming to inflict harm on the girls, and that no one should have had any doubt about his murderous intentions which could only have been addressed with “force not dialogue.” Morphew asked for clarification as to whether there was emerging in the country, particularly among the youth, a notion that force was not the solution but that pacifism and discussion instead was the path to the resolution of violence. Hunter clarified that, "these girls acted exactly as they had been taught by their teachers, by their churches, by the United States government...” He explained that the murderous individual promised the girls he would do them no harm, which the girls had fallen victim to because of their preconditioned pacifistic mindset, except for one Filipino girl. Hunter stated that the girls were killed, "one at a time exactly the way Soviet Russia is knocking off countries exactly one after the other." He emphasized that, "surely we should have learned from the assassination of Kennedy that a Communist is a Communist and that a killer is a killer.” When asked by Morphew for clarification as to whether or not the girls were responsible for their own death, Hunter read an excerpt from an article in his publication, Tactics, which stated that, 
Richard Speck is not the only guilty party in the murder of the eight student nurses in Chicago on July 14, 1966. All who directly or indirectly conditioned the murder victims for dependence on dialogue instead of on resistance are accessories in the horrible crime. They are all who helped shape the minds of these girls whether teachers, newspaper editors, television commentators, clergyman or legislators, they all share the guilt. ${ }^{93}$

Hunter drew a comparison between the tragic murders in Chicago and another violent incident in Texas. In the case of Chicago the sole survivor was a Filipino girl who outwitted the assailant, while in Texas it was a Puerto Rican and not “a native born American,” who had survived. Hunter noted that this was the product of hesitation and weakness on the part of America’s political leaders, and that if the government would embrace a policy of winning against the Communists; this would strengthen America's resolve in the rest of the population. Advocates of gun control measures following the Texas incident, according to Hunter, were misunderstanding the real problem that the philosophy of nonviolence itself and the idea of being open-minded to various ways of thinking in the face of danger, were ultimately responsible for putting the lives of America's youth in jeopardy. Hunter attributed these disturbing developments to the rejection of firm principles and certainty on truth, and that open dialogue was all the product of brainwashing efforts by Communist subversives as occurred in the prisoner of war camps in the Korean War. Morphew asked about the apparent naïveté on the part of America’s youth and the trend toward open discussion and civil dialogue, which was, in the words of Hunter, "suicidal and stupid and conspiratorial and base.” Hunter urged parents to teach America's youth to rebuff such thinking and instead meet evil in the world with stern resolve. ${ }^{94}$

In another Forum show, Hunter discussed the assassination of President Kennedy and the Warren Commission Report, which he discredited as a political concession made not to identify the "real culprit.” Hunter was critical of the report for, "taking the Communists off the hook,” and he indicted the FBI in its investigation for not identifying the true larger international Communist plot beyond the mere lone gunman theory involving Lee Harvey Oswald. The Warren Report, 
according to Hunter, was written in a way such that the public would be convinced it had received the entire story from the "obedient press.” The Warren Report was full of "subterfuges” failing to prosecute the real assassin; that of international Communism. This was done for political purposes, as Hunter stated, to "take Communism off the hot seat to make sure that the State Department does not get the blame it should get for creating the climate in the United States that made Oswald possible; by being the most effective element of anti-anti-Communism.” Through the Warren Report, according to Hunter, U.S. policy leaders essentially were trying to silence the most ardent anti-Communists in America's political culture, as evident in the bias exhibited in the hearings which failed to "bring out the Communist involvement.” The mainstream news print media, he explained, also played its role in downplaying the significance of Communist subversion. America's political and media establishment, Hunter asserted, failed to become acquainted with the refined psychological tactics employed by Communists. ${ }^{95}$

When asked on another program about Communist tactics as related to the assassination of President John F. Kennedy, which host Morphew noted the accusations by "left-wing commentators” of the involvement of right-wing extremists, Hunter again described the overall "propaganda climate” perpetuated by media elites who advanced the notion that it was inconceivable for a Communist to have assassinated the president. Hunter warned that the careful management of news information facilitated the pro-Communist climate in which sympathizers go out of their way to mind the sensitivities of the Soviet Union and avoid identifying Communists as the perpetrator of the Kennedy assassination, and instead blame the "rightists" of the "Goldwater stripe.” He emphasized again that the official policy of the United States government was "anti-anti-Communism," and clarified the definition of conservatism which he stated was, “conserving the old-fashioned liberal principles of Jefferson, George Washington and our nation traditionally.” The discussion returned again to the anti-Communist grassroots movement and their rising awareness of the international threat, about which Hunter claimed that 
Americans were indeed being subjected to a "softening up,” a brainwashing by Communists, and that access to anti-Communist information was being limited by the news management effort. America's political leaders in particular, were being subjected to what he called, "the lies and the deceits and the distortions that go under the name of news management.” Hunter advised Americans to do the work of acquiring the proper facts from anti-Communist publications such as Hunters' Tactics, and use basic common sense. ${ }^{96}$

Regarding the Vietnam antiwar protest movement as addressed in another Forum program, Hunter stated that, “There is no doubt, it is fully documented that the so-called peace movement, the so-called anti-war movement are part of a coordinated military operation by the Communists to defeat the United States.” As host Morphew suggested in his question, and as Hunter confirmed, demonstrations put on by antiwar protesters were under the direction of Communist orchestrators though the demonstrators themselves repeatedly deny the presence of Communist involvement. In particular, The Students for Democratic Society was identified by Hunter as a "Socialist youth group” and had recently “officially thrown off their Socialist garb and revealed themselves as a Red Front.” College students, he warned, were particularly susceptible to falling under the influence of such a "front” organization, which encouraged a culture of denying actual Communist identification as part of its psychological strategy of deceit and deception to focus on anti-Communists as the real threat. Such an organization, according to Hunter, was engaged in not explicit treasonous activity, but instead displayed anti-American symbols and was aided by a liberal media which failed to criticize such acts of un-patriotism; seeking instead to facilitate a climate of criticism of those who oppose anti-Americanism. ${ }^{97}$

Congressman John Bell Williams, who recounted his speech on Communist infiltration into the Vietnam antiwar protest and civil rights movement, drew a connection between antiwar demonstrators and the existing civil rights activism over the years. According to Williams, the Student Nonviolent Coordinating Committee was of particular concern where certain activist 
leaders involved in Vietnam War protests had also previously been involved in Mississippi, according to Williams, "where they had been stirring up trouble in the civil rights movement.” The congressman described Martin Luther King Jr. as, "the grand high priest of civil disobedience," and the "high and mighty emperor of discord." Williams added that King was an advocate of Communist China’s entry into the United Nations and in the past had supported “pink-tinged causes” and maintained associations with "known Communists” and had participated in the "Highlander Folk School Communist Training Camp.” According to Williams, these protesters "advocate nothing less than a policy of surrender and they'd like to turn Vietnam over to the Communists.” Morphew added that these protesters were giving advice to individuals about how to disobey the draft laws and avoid entry into the war. For Representative Williams the pro-Communist link between Vietnam antiwar demonstrators and Negro civil rights protesters was clear. Noting the well-financed effort to travel across the country and engage in coordinated campaigns of agitation, he also cited the financial conflict of interests between Washington Daily News reporters and their participation in what he described as "so-called poverty programs." This, according to the congressman, was evidence of media bias in the failure of the press to maintain a professional separation from government so that it might objectively report on governmental activities. $^{98}$

As a final example of how the Council's Forum reflected the Ideological UnAmericanism frame cluster, Thurmond and Hunter were both featured as guests to discuss the state of anti-Communism in America. After Hunter opened the discussion by describing a meeting of international Communists who identified the grassroots anti-Communist movement in the United States as a target for elimination, Thurmond joined in by pointing out the "muzzling of the military” concerning the dangers of Communism. The Fulbright Memorandum, Hunter added, was related to the silencing of anti-Communist military leaders, and was "a kidnapping of government" by liberals who perpetuate an ideology which suggests that a "sophisticated group" 
of elites "can do the thinking for the public.” Thurmond commended Hunter for his contributions to their cause and noted Hunter's testimony concerning the effort to silence anti-Communists in the American government, particularly in the military. Hunter reiterated his often stated definition of an "anti-anti-Communist” as "he or she who opposes opposition to Communism," and he considered the anti-anti-Communist front to be far more dangerous to the United States than actual Communists. ${ }^{99}$

2.4 Federal Government Tyranny and the Struggle for the Preservation of Freedom

As outlined in the previous chapter, the frame cluster referred to as Struggle for the Preservation of Freedom is structured around the notion of white liberty through the preservation of a racially segregated social order. The 'struggle' itself is defined by segregationist efforts to push back against government violations of white peoples' constitutional prerogatives to have freedom of choice in their rejection of racial integration and racial equality; to be free from federal coercion to interact with those seen as unfit to enjoy the full benefits of democracy. The federal government, as segregationists saw it, was overstepping its authority, violating sovereignty of the states, depriving individual liberties guaranteed by the Constitution and disrespecting the personal freedoms of the South's citizens in particular. Citizenship in the minds of segregationists, of course, was to be understood in terms of whiteness. Under the guise of supposedly protecting the civil rights of the Negro, the federal government, as segregationists believed, was in fact depriving the rights of white citizens and actually jeopardizing the wellbeing of the Negro by granting to him underserved privileges.

A documentary called, “Oxford U.S.A.,” that aired on the Citizens' Council Forum is a rather clever effort, against what was perceived to be unfair media portrayals, to portray as innocent victims, southern white opponents of federal government efforts to enforce civil rights reforms through the use of U.S. marshals. From the perspective of those opposed to black student James Meredith’s entry into the University of Mississippi, federal government military power 
was being used to crush freedom by privileging the so-called rights of one single Negro over that of the majority of decent, law-abiding, goodhearted Americans who were only exercising their God-given constitutional right to protect the racial integrity of the Republic which the Founders handed down to them. Images shown in the video include the movement of federal military machinery and troops into the sovereign spaces of the South by the thousands, according to the narrator, "in full battle dress” creating "the conditions of war.” This was an "invasion” on the part of the federal government, violating the Constitution, as U.S. marshals subjected local residents to “unreasonable searches and seizures,” checking automobiles presumably for firearms. ${ }^{100}$

A white student recounted his witnessing of one particular girl whose car was searched and whose personal belongings, including underwear in a suitcase, was being rummaged through by “a Negro soldier," and who held up the personal items of this female individual in a joking and humorous manner together with other soldiers. There were also two deaths reported, as one other student recounted, which the narrator contextualized as a violation of the amendment which protects against loss of life, liberty and property without due process of law. Also mentioned in the narration are students who were held as prisoners by federal marshals but were not actually charged with or arrested for anything, providing another example of the violation of people's freedoms there. Another student recounted how the troops interrogated him and tried to get him to bear false witness against other students concerning their involvement in a riot. ${ }^{101}$

Such images of young college students recounting their traumatic experiences under the abuse of U.S. military personnel at the service of Negro interests, one can imagine, did nothing but inflame the already impassioned southern white residents who identified with the segregationist cause against civil rights enforcement. As the narrator explained following the recounting of events by students, “people throughout the nation were enraged by the action,” and, "many of them traveled to Oxford to protest personally the unwarranted action.” This included Major General Edwin A. Walker who, as the narrator explained, was now a civilian and wanted 
to be on the segregationist side, and was arrested by federal officials, later to be released and “finally vindicated of federal charges,” arguing that his constitutional rights had been violated. ${ }^{102}$

Another individual interviewed explained that Meredith was not the real threat in this situation but that this was the end of American democracy because the federal government had, “encroached on us from every field of endeavor one can think of.” He explained that Meredith was not the primary concern in this issue and in fact, "was not qualified to enter the university," and that, "if he had been of a Caucasian race he couldn't have entered. Meredith, the student made clear, had other options based on his less than stellar academic record but still had the support of the federal courts for his admission into the University of Mississippi. As the narrator added about Meredith's underserved preferential treatment by the government at the expense of whites, "his unqualified rights as a student were upheld, but what of the rights of the other students, were they allowed their freedom?” Another student interviewee recounted Meredith’s entry into a particular classroom which prompted many students to want to depart from the class, which the U.S. marshals prevented them from doing until it ended. The narrator continued to question Meredith’s academic record noting that although he benefited from troop escorts from class to class, and the Supreme Court advocated for his entry into the University, Meredith had to still meet the same academic standards as other students there. As the narrator stated,

He could not rely on federal forces or his private tutors to take tests for him. James Meredith is not a good student. In fact James Meredith did not make his grades. He failed to show up for tests. Had any other student conducted himself as did, Meredith he would surely have been dropped from the rolls of the university. ${ }^{103}$

As a final interviewee, Governor John T. Patterson of Alabama complained about the unfair treatment by the federal government in the matter of Meredith's entry into the University of Mississippi. Patterson stated that, "I thought then and I think now that the state of Mississippi and its people were entitled to at least the same kind of treatment that we have seen the 
Communist Party of America receive at the hands of the United States Supreme Court.” The U.S. Supreme Court, according to the governor, "permitted the Communist Party to appeal their case three times over the span of twelve years," while they operated against the interests of the United States. Following Governor Patterson's description of the federal government's use of federal troops against Mississippi in the Meredith incident as, “a flagrant abuse of arbitrary power," the narrator concluded the documentary on a solemn note, seeing the entire affair as a movement away from freedom for the people, away from local control and toward Communist tyranny. ${ }^{104}$

In another Forum program, Representative George Andrews, a Democrat from Alabama, introduced Governor Patterson who expressed his statement of opposition to various proposals for civil rights bills at the time. The governor noted his particular concern and annoyance with the civil rights bill of 1957, creating the Civil Rights Commission, about which he stated,

They have further divided the races in the South. They have created hostility and animosity between the local officials and the federal government and all of the activities of the Civil Rights Commission has not resulted in a single additional person being placed on any voters' list. It's been a complete failure and caused a great deal of hostility and trouble to the people, not only the South, but of this whole nation. ${ }^{105}$

Patterson proceeded to describe the way in which local voter registration officials in his state had been "harassed" by the "unconstitutional encroachment" of the executive branch of the United States government through the Civil Rights Commission. He characterized the investigative activities of the Commission as a lawless government agency existing only for the purpose of making mischief, doing nothing to improve race relations but instead creating more racial strife, and breaking down the proper constitutional process by which such matters should be handled. The governor argued that the federal government's aim was to destroy public education in the South by forcing integration on the free people of states like Alabama who, he exclaimed, would "sacrifice their public school system completely before they would submit to 
integration of the races in the public schools.” Representative Andrews added that most Alabamians would refuse to integrate, and Patterson insisted that if the federal government did not leave his state alone then there would be no public education in Alabama and that, "both races are going to suffer and the Negro race will suffer worst of all.” Host Morphew, framing a larger question about federal government usurpation of local authority beyond the South, asked Patterson if such federal government powers could be applied in other nefarious ways. Governor Patterson urged all Americans to be concerned because federal troops may be used in other instances to, "force things on people in other sections of this country in fields other than segregation and other than race matters.” Representative George Andrews concluded the discussion by emphasizing the resolve on the part of opponents to the passage of further civil rights legislation. ${ }^{106}$

Attorney General Joe T. Patterson of Mississippi appeared as guest on the Forum to make the public aware of how the federal government was meddling in the state affairs of Mississippi, particularly in voter registration and litigation over local educational issues. Federal agents, as Morphew phrased in his question, engage in various methods and tactics including questioning “members of the Negro race” and examining records of local registrars. Attorney General Patterson advised these registrars not to cooperate with federal officials and refuse to answer their questions, plead the Fifth Amendment and decline to submit requested documents by federal agents until specified in a legal order by federal courts. Both Morphew and Patterson described the activities of federal officials investigating the records of registrars as a "fishing expedition," and that the activities of the federal government's investigation into the matters of local registrars was nothing more than a government agency seeking to justify its own existence by encouraging local residents to register complaints. The Civil Rights Commission, according to Patterson, was ultimately created for the purpose of functioning as "an instrumentality of harassment" in the southern states. Evidence of the uselessness of the Commission was its dearth of complaints. 
Patterson explained that, "the Negro population of Mississippi was not being mistreated as they had been presented to have been being mistreated, and it also indicates that they are not as dissatisfied frankly, as they would have them be.” Morphew described these federal officials as, “swarms of Justice Department agents invading Mississippi in the South.”107

With Representative Albert Watson from South Carolina as the guest, the Council's Forum continued in its discussion of the tyranny of civil rights enforcement. At the start of the program, host Morphew noted that Representative Watson had resigned from Congress and sought reelection as a member of the Republican Party after being stripped from his seniority for supporting the presidential candidacy of Barry Goldwater. The representative felt that he was being punished for his political differences with liberal members of the Democratic Party and so he decided to resign and change his party affiliation. The discussion then turned to the civil rights bill, which Watson felt there was no need for such legislation, but was another example of the federal government taking responsibilities away from state and local governments. Morphew wanted the congressman to emphasize that in fact it was the right of the states to determine voting qualifications and that therefore the federal government had no constitutional authority to interfere in local matters. In particular, Watson took issue with individuals having the right to vote without any literacy tests. This was a part of what the representative saw as political elites giving into the demands of activist pressure groups. The appointment of federal registrars by the Civil Service Commission to assist in the registering of voters was another "dangerous" example cited by the congressman. Federal registrars, Morphew speculated, could play the nefarious role of influencing individuals registering to vote on the basis of whether or not they agreed with the registrars' political views or choice of whom to vote for. Watson also noted that people often held the mistaken view that conservatives were opposed to providing assistance to the poor. Instead, the congressman explained, "We believe in helping them, but helping them in the traditional manner of through the great free enterprise system, to give them jobs, to retrain them.” According 
to Watson, the current slew of legislation aimed at providing assistance to impoverished people "from the cradle to the grave" was a philosophy which would "destroy the basic free enterprise system in America...bankrupting this great country of ours.” 108

On another Forum show, Senator Thurmond appeared yet again, describing the most recent proposed civil rights legislation in Congress as a "power grab" as evidenced by the loss of authority by local voting registrars under the say-so of the federal government to take over registration operations. Another illustration of Thurmond's argument was on the matter of voter education qualifications as determined by the federal government. According to the senator, a sixth-grade education, as the government decided, was not enough to vote and was unconstitutional. Another point with regard to education was that the civil rights bill allowed the U.S. attorney general to bring a lawsuit in order to facilitate the desegregation of educational facilities. Thurmond believed the government should not take a side on the matter of whether to maintain segregation or to desegregate education. ${ }^{109}$

Host Morphew asked Thurmond to comment on the idea that other regions of the United States outside the South needed to be concerned with various civil rights legislation being proposed. After pointing out that the U.S. government was bribing schools by giving financial and technical aid only to schools that desegregated, Thurmond also noted that northerners were becoming aggravated with the busing system instituted to desegregate schools there. Federal civil rights legislation and enforcement, as Morphew and Thurmond agreed, applied to all aspects of life in the United States wherever an accusation of discrimination could be successfully made. Businesspeople and banking interests, farmers and “practically every citizen would be affected by this so-called civil rights bill,” as Thurmond stated. As Morphew added, it would be the bureaucrats who would make the determination as to the validity of discrimination claims and subject those accused of discrimination to undo financial burdens. Thurmond continued to explain the significance of the government forcing individual owners of private businesses to 
abide by federal anti-discrimination laws as an "invasion of his private rights.” He stated that, "I think it's going to set a terrible precedent when people who own private property are going to have their property so regulated and so controlled that a man can't use that property anyway that he desires to." 110

Thurmond reiterated an often stated argument on another Forum program about authority resting with the states and not federal election officials in determining voting qualifications. He noted South Carolina's voting qualifications which required the ability to read and write the Constitution, or ownership of at least three-hundred dollars' worth of property which, Thurmond emphasized, was South Carolina’s sovereign right to maintain and not the federal governments' to supersede it. Morphew also noted how individuals seeking to redress grievances regarding infringements on their voting rights can avoid enlisting the services of a lawyer and instead rely on the Federal Attorney General as legal counsel in such a matter, which Thurmond described as, “a very dangerous precedent...fostering and giving impetus to integration in every way possible...”

In giving his response to a proposed public accommodations civil rights bill regarding the selling of private property in a nondiscriminatory way, Thurmond made the assertion that, "to make a man sell to someone he doesn’t want to or serve someone he doesn’t care to, is depriving him of the use of his property.” A man's property rights took precedence, Thurmond explained, "so long as he does not disturb or hurt others.” Thurmond noted that there were those who were actually in favor of integration who expressed their opposition to the public accommodations bill on the principle that the federal government was in gross violation of private property rights. Civil rights legislation aimed at breaking down racial discrimination in the selling and use of private property, to Thurmond, was infringing on fundamental constitutional rights of private ownership which was a sign of America's move towards tyrannical rule. Thurmond stated that, 
"When the government steps in and directs a use of property, controls property; that is the beginning of a dictatorship.”111

As Morphew phrased in his question to Thurmond, the proposed public accommodations bill threatened the particular rights of white people. He asked, "Many persons have been led to believe that what the Negro is seeking in all of this is equality. Do you believe that it is real equality that they're looking for, or is it more in the line of preferential treatment?” Thurmond confirmed that it was indeed preferential treatment that Negroes wanted in compensation for their suffering going back multiple generations which the government was willing to concede to by selecting for promotion in civil service jobs, not the most qualified persons, but giving preference to the employment of undeserving Negroes. Morphew confirmed that, "So that actually instead of removing discrimination, which many of us have been told is the purpose of all of the civil rights controversy, what is actually being done now is to discriminate against white people in favor of the Negro.” Thurmond again confirmed that discrimination was being promoted by the federal government against the white man, and he reiterated that Congress had no constitutional authority to bring into law such violations of property rights. ${ }^{112}$

One must keep in mind that the logic of the pro-segregationist grievance against federal authority was not limited to the matter of civil rights but extended to other perceived violations of American freedoms. For example, Congressman Glenn Andrews who was a Republican from Alabama and a member of the House Education and Labor Committee, appeared on the Council's Forum to discuss so-called right-to-work laws, which Morphew described as being aimed at preventing “compulsory unionism,” in the interest of preserving a workers' right to decide for themselves if they will belong to a union or not. Congressman Andrews noted the hypocrisy on the part of the people who advocated for a new voting rights bill that would extend the franchise to all individuals while at the same time advocating coercion of union membership and coercion of payment of union dues ultimately for the use and overall purpose of influencing politics. He 
noted that emotionalism and the following of public opinion was corrupting politics as evidenced by the recent passage of civil rights legislation. ${ }^{113}$

Congressman Ben Jenson, a Republican of Iowa, and John B. Trevor Jr. from New York City, were guests on another show to discuss violations of American liberty by the federal government. John B. Trevor Jr. was a member of the Executive Committee of the American Coalition of Patriotic Societies, which existed for the purpose to “keep America, American.” The organization, according to Trevor Jr., included a membership of approximately four million persons, and was founded in1929 around the immigration issue at the time. Trevor Jr. noted that there were essentially two positions on immigration being debated in the nation. The first, as he explained, was advocated by those who were "in favor of sensible and adequate restrictions on immigration by fair and appropriate means," while the other side wanted "unrestricted immigration.” Congressman Jensen added that certain politicians had not embraced American patriotism as their guiding philosophy in sensible restrictions on prospective immigrants and that they "never had in their heart the true meaning of Americanism.” Many immigration policy makers, he explained, “are ill-advised, they've listened to too many people that are of possibly a subversive nature." Citing the presence of Communism, congressmen Jenson noted that, "we could do nothing that would harm our country more than permitting subversives by the thousands to come into our country and to teach some foreign ideology...” The allowance of large blocks of immigrants from a single nationality group to enter the United States, as host Morphew stated, would "make them easier for politicians to manipulate and turn the nationality blocks into voting blocks,” which Trevor Jr. agreed with. ${ }^{114}$

Returning back to the specific theme of governmental tyranny, Morphew asked Representative Jensen about an over-arching Communist plan to centralize governing authority at the expense of local and state government, which the congressman answered by explaining the dividing up geographically of America into separate "eleven river valley” regions to allow the 
president total control over the nation. Noting the prescient wisdom of the Founding Fathers, Jensen described their foresight in seeing the great possibility of the emergence of a dictatorship in the United States if local state militias were not instituted to restrain the abusive power of federal military authority. The establishment of regional state military entities, as Jensen explained, was for the preservation of the republic itself. Present-day political developments, he warned, may be heading in a direction away from what the Founders had in mind. ${ }^{115}$

In another Forum discussion, Congressman Walter Rodgers from Texas, who fought against passage of a civil rights bill, also wanted to discuss the growing centralization of governing authority, particularly federal usurpation of power over the sovereign state of Texas. This program featured a very lengthy conversation about violation of states’ rights, citing a couple of detailed examples including the Texas tidelands and offshore drilling for oil, and another about infringement on natural gas rights. Centralization of the government, as Representative Rodgers concluded in the examples he provided, was destructive of individual freedoms. The congressman also made note of federal troops being sent into Little Rock, Arkansas as an illustration of the concentration of power in the government as part of a broader list of grievances against the growing tyranny of federal violation of states’ rights. ${ }^{116}$

As illustrated in the above selected examples, the Citizens' Council Forum featured numerous guests that relied on frame argumentation which reflected the frame cluster referred to in this research as, Struggle for the Preservation of Freedom, which includes a collection of segregationist frames aimed at highlighting the usurpation of local authority on the part of a perceived tyrannical federal government. Like-minded adherents to the segregationist cause were urged by Forum guests to actively resist federal intrusion and violations of individual rights; liberties understood as reserved exclusively for the presumed advanced white race. Worthy of democratic freedoms, whites were to be recognized as superior beings above the lowly Negro who should only enjoy that which his inherently limited racial temperament permits, and not be 
granted undue privileges. The logic of white citizenship and Negro subjection in modern society, as featured in the Council's broadcast media, was reinforced with more "objective” sounding frame argumentation which is discussed in the next section.

\subsection{Segregationist Scientists and the Effort against Tyrannical Equalitarian Dogma}

As detailed in the previous chapter, the rhetoric of science and historical observation were often employed by the Citizens' Council in its official paper to support the idea that Negroes are unredeemable in their intellectual inferiority, and therefore limits must be placed on their existence in a free and open society. The same frame argumentation can be seen on the Council's Forum where individuals touted as scientific experts were featured as guests. These segregationist scientists were eager to share with the audience their presumably objective observations in support of racial separation in society under the direction of the apparently intellectually superior white race.

In a "Project: Understanding” documentary featured on a Forum program, segregationist scientist Carleton Putnam, and his book, Race and Reason: A Yankee View, are celebrated in Mississippi’s “Race and Reason Day.” Putnam provided for southern segregationists, an important litany of arguments dressed up in the thin veneer or scientific rhetoric. Giving the South advice about how to construct rational defenses of their segregated way of life, Putnam tried to provide a more effective intellectual template for the segregationist cause. Putnam's book was touted by narrator Morphew as highly influential among "prominent Americans among all walks of life,” and very popular with the people of the South. In Jackson, Mississippi, Congressman John Bell Williams invited Putnam to speak at a "twenty-five dollar-a-plate” banquet with an "overflow crowd.” Governor Ross Barnett was in attendance and read an official proclamation honoring Dr. Putnam in his efforts to create a proper understanding of racial issues for audiences outside the South, particularly in the North. ${ }^{117}$ 
During his address, Putnam described timeless ideals which Mississippi cherished and championed in its efforts to resist the inundation of apparent false scientific information.

Mississippians, according to Putnam, were not interested in selling their souls for the corrupting niceties of politics but instead remained steadfast in their resistance to the "cult" of progressive left-wing ideology which aimed to impose their social programs on society without respect for the fact of inherited racial differences. The so-called "equalitarian scientists," according to Putnam, were engaged in wishful thinking by dismissing the overwhelming evidence which apparently rested with the pro-segregationist side of the scientific argument. Through the efforts of leftist scientists and a sympathetic liberal media, academic freedom, Putnam suggested, was under threat. Against this apparent attempt to crush intellectual liberty by members of the southern press who agreed with integrationists, Putnam stated that, "I’d like to say to you editors who are the servants of northern masters, that I'd rather quit my job than betray the people in my hometown.” He continued to describe his preference for making sacrifices and standing firm in his scientific position rather than selling out his descendants. ${ }^{118}$

Putnam wanted to extend the significance of his points beyond the antics of "left-wing pseudo scientists” and make a larger point about a pervasive doctrine that was corrupting the American consciousness. In refuting scientific observations about the social condition of black people as a product of environment, he stated that, "No one wants to stress the importance of environment more than I do, no one wants to improve the Negroes' environment more than I do, but it would be difficult to find a more profound, a more complete and a more inexcusable falsehood..." than the idea that black inferiority is not the product of the limits of their presumed racial biology. To emphasize his point against the integrationists and their rejection of the logic of innate unequal racial differences, Putnam took the time to cite Abraham Lincoln's racist remarks regarding the supposed natural inferiority of blacks and his rejection of racial equality, words well known to members of the pro-segregationist effort, and which were featured in the previous 
chapter. Putnam emphasized that Lincoln preferred state government decision-making authority regarding the enfranchisement of only "very intelligent” Negroes "under the control of the states.” He aimed to clarify Lincoln's true positions on the matter of race relations in society; that Lincoln was never in favor of the federal government forcing the integration of the races upon the states. $^{119}$

Making an argument that reflects the grand theme of this entire research project, that segregationists saw themselves as up against evil in a struggle to preserve the very foundations of civilization itself, Putnam railed against integrationist clergy and the liberal media, stating that, There's been no case in history where whites and blacks have integrated without destruction of the white civilization, and there is no human right greater than the right of the civilization to defend itself against such destruction. That right you would watch the federal government take forcibly from the South while you sit with your hands folded in prayer. ${ }^{120}$

Putnam expressed his frustration and fatigue with those who conformed themselves to the popular whims of liberal idealists who wished to force their fanciful notions upon parents regarding their children's educational well-being. He then returned back to his critique of environmental explanations of black inferiority, and argued that accepting such a proposition led to the logical conclusion of making restitution to Negroes for their inferior social position, which Putnam rejected. The spreading of the integrationist “environmentalist view,” according to Putnam, resulted in a "completely indoctrinated society in the North.” The Supreme Court ruling which desegregated public institutions, according to Putnam, was the product of mere public opinion. To effectively counter this indoctrination, Putnam advised southerners to abandon the often employed southern rhetorical defense of states' rights because audiences outside the South were not sympathetic to this notion. This argument, he explained, only did the South harm in the North. Instead, there was only one argument that would perhaps make the strongest impact on northerners. Putnam urged his southern audience to do the following. 
Tell the North over and over again that you are fighting for the integrity of your civilization. Remind them that there has never been a case in history where whites and blacks have lived together without segregation in such numbers as you have in the South today and have failed in the end to intermarry. Remind them that such intermarriage has always resulted in the deterioration of the white civilization. Point out to them that the facts of science, when viewed through unbiased eyes, support the facts of history. Show them that the historical evidence is what you would expect to find from the scientific evidence, the genetic nature of the latter accounting for the deterioration apparent in the former. Make clear that you have in most cases done all you could, and a lot more than most, to improve environment for the Negro that you intend to do even more. Continue forward in that area; but when it comes to social segregation say to the North, here we stand foursquare. ${ }^{121}$

Putnam also warned his audience to guard themselves against the infectious notions of leftists who advocate for social change and to "remind him that every burglar breaks into a house wants change. He wants to change the possession of the savings and heirlooms of the owner who's conserved them through the years, and sometimes nations and races want to do the same thing.” Putnam stressed to the South that northerners needed correction in their misunderstandings of the idea that, "all men are created equal," and that it has not applied in the context of, “cultural, social or genetic equality, except in Communist countries.” The equalitarians, he explained, are for overturning the tried-and-true principles of their forefathers in favor of appeasing those who misunderstand freedom. Southerners should not be interested in pleasing others but should remain resolved in their segregationist position and should encourage their political leaders to engage wholeheartedly in combating media misrepresentations of the southern way of life with regard to race relations. Putnam wondered why it was that northerners so misunderstood the southern position on segregation, to which he again suggested that the states' rights argument itself was a weakness as a defensive position and not an offensive weapon of power against the opposition in the realization that morality, and righteousness and science was on the side of segregationists. In conclusion, Putnam urged the South to not give up and remain hopeful in their cause to attract like-minded individuals. ${ }^{122}$ 
In another Forum program featuring the segregationist position on the science of race, Dr. Putnam returned as a guest alongside Dr. Robert Gayre of Edinborough Scotland, who was the editor of Mankind Quarterly, and who complained that the English-speaking press was hostile in its criticisms of his views at the South African Genetics Congress. He felt that generally there existed in the newsprint editorial media a "preconceived policy" that did not give fair coverage to contrasting views with “liberal policy.” Dr. Putnam also agreed and urged people to study information for themselves in order to circumvent the "dogma” and "propaganda” which pervaded the American editorial news media. ${ }^{123}$

Putnam continued by explaining the views of the so-called "equalitarian scientist," which, to his mind, emphasized environmental and cultural explanations for social conditions of the Negro, and that the "evolutionary retardation" of the Negro can be reversed through social interaction with whites. Putnam rejected this notion because of his certainty that racial differences between blacks and whites were rooted in unchangeable hereditary characteristics. Dr. Gayre also agreed and cited evidence from intelligence studies on twins and research on the intelligence of children in foster homes to support the inherent racial difference argument. Gayre noted that nature produced different races first and that cultural differences sprang from natural racial differences. $^{124}$

After host Morphew asked Dr. Gayre to comment on the mass indoctrination by the “equalitarian environmentalist school of thought," Gayre noted that it was the "Anglo-Saxon or English-speaking countries” which were sympathetic to this philosophy as opposed to the "Latin speaking countries” such as Italy, where there was a proper respect for maintaining a society based upon the apparent scientific realities of racial difference. Putnam described the “persecution” and “dogmatic propagandizing” by critics of their position on racial difference, which Dr. Gayre agreed with and even noted the historical example of Galileo who was regarded as a heretic for his resistance to the dominant doctrine of his age similar to themselves as 
scientists out of step with mainstream academia's rejection of racial difference. Putnam also asserted that critics were more interested in criticizing than in rebutting their particular scientific points, and as Dr. Gayre added, scientific notions in line with the modern equalitarian doctrine were outdated and "furbished up mainly in left-wing schools of thought, dominated often by Communism...”125

Another Forum show revisited the question of black self-government in Rhodesia with Dr. Putnam as a guest again, who stated that, "There has never been a stable free society run by a majority of Negroes," and he disagreed with the idea of greater Negro inclusion into Rhodesian civil society. Instability and disaster is the only product of Negro governments, according to Putnam, as he rejected the example of Liberia often cited by opponents of his views. Adding to the discussion, host Morphew asked the doctor, "Well actually isn’t it a fact that the white population actually built Rhodesia taking it from the jungle to the civilization which exists there today?” Putnam confirmed this notion and added that science proves to the contrary that Negroes would ever be ready for self-rule. Countries such as the United States and England, he explained, were making the grave error of trying to move in the direction of racial integration and that the general public in these countries was being influenced by a hierarchy of scientific deception corrupting educational institutions away from the truth. Genetically embedded, innate racial differences, Putnam emphasized, can never be bred out of racial groups in the interest of a racially integrated society. ${ }^{126}$

After Morphew framed a question to illustrate the absurdity of suggesting Rhodesia include in its government a majority of the indigenous population, pointing out how ridiculous it would have been for the international community at the time of America's move toward independence to suggest that it include in its government a majority of American Indians, Putnam stated that, "The Indian being a sub stock of the Mongolian race would have been further along the line in the way of being trained in the way of stability to take over a majority government than 
the Negro race is today in Rhodesia.” On the matter of independence movements in Africa and the emerging nations there, Morphew indicted the U.S. State Department and other international bodies for reacting reflexively, failing to reflect the opinion of the American people. Dr. Putnam confirmed Morphew’s supposition that politicians indeed exhibited contrary views on racial difference which probably did not reflect the truth of public opinion. These popular views, particularly the "Boas cult of environmentalism," he specified, had an indoctrinating effect on America's educational institutions. Putnam also noted that although there were exceptions to the general inferior nature of Negroes, it was "the problem of the averages" that needed to be addressed in any consideration of civil society. When Morphew asked about the slogan of "one man one vote," Putnam rejected this idea as not equivalent to free society. Everything in the Negroes’ possession in contemporary society was the product of efforts by whites on their behalf, as he expressed, and that, "the white man has nothing to apologize for as far as the Negro is concerned,” even taking into consideration white cruelties against blacks. Putnam added that, “...no Negro has ever found a better haven of opportunity than he has today in the United States and had before the integration decision of 1954.”127

On yet another Forum program to expose the public to the views of segregationist scientists, sociologist Dr. Ernst van den Haag, questioned the evidence used in the Supreme Court ruling in Brown. In arguing that integrated education for black children was harmful to their wellbeing, he questioned Kenneth Clark’s sociological experiments with white and black dolls. Dr. van den Haag stated that, "in our culture for instance, and in most cultures white or light colors stand for purity, innocence, joy, and dark colors such as black, stand for sorrow, death, terrors, evil, so that children of any color themselves may prefer the white doll.” The doctor took issue with the experiment noting that there were no controls for comparison that would produce more objective results, such as a test in which one could observe the preferences for a black or white doll in the case of black children who were not subjected to segregated education. He explained 
that, "If you wanted to attribute the alleged damage to segregation then you should also perform this sort of experiment with non-segregated Negro children and see whether their response differs. If it does, you may have a point.” The doctor described such an experiment involving children in a mixed school which produced results where "even more of the Negro children preferred the white doll and identified with it.” The doctor concluded that the idea of harm to the psychological well-being of black children through segregated education was not proved by Kenneth Clark's experiment, but the results in the mixed-race school environment showed that, "more such harm arises through intermixture, through desegregation, through congregation than occurs when there is segregation.” The doctor asserted that professor Clark had never made his sociological findings available to the court.

Dr. van den Haag cited another study by professor Gregor of the University of Hawaii, who found that in segregated education "ninety-five percent of the Negro children preferred Negro dolls as nice dolls, dolls they prefer to play with and finally, as the dolls with whom they correctly identified themselves.” Again, the doctors' ultimate conclusion was that the psychological well-being of Negro children was healthiest in a segregated situation according to experiments that produced results contrary to what Kenneth Clark found. He concluded that, “compulsory congregation, the compulsory togetherness that the Supreme Court has decreed is likely not to reduce, but rather to increase the mutual hostility of the two groups.” Theorizing about the sociology of happiness with regard to adolescent mental health, he made the assertion that, "Negro children were, by their being with white children, developing an aspiration level which would be considerably in excess of their attainment level," that in fact black children were being made, “unnecessarily unhappy about themselves” when subjected to an integrated educational system. Finally, it was Dr. van den Haag's hope that at some point in the future the Supreme Court ruling in Brown would be overturned because the sociological evidence presented before the Court had no basis in sound scientific reasoning. ${ }^{128}$ 
Interracial marriage and interracial dating was the topic on another Forum program, specifically a controversy over remarks made about interracial marriage before a group of public school teachers in an educational training session in the Richmond, Virginia area. Dr. Henry E. Garrett was the guest. His credentials, as mentioned, included sixteen years as head of the Department of Psychology, and Professor Emeritus at Columbia University in New York City. He was also a visiting professor at the University of Virginia, and past president of the American Psychological Association. Taking issue with the notion proposed by so-called "extreme liberals," that interracial marriage may perhaps be a solution to many of the racial issues in America, host Morphew first raised for Dr. Garrett the question of the true intent of the integrationist leaders who claimed to not be interested in racial intermarriage, but whose questionable activism seemed to suggest otherwise. Dr. Garrett advised that one should consider several important factors relating to the issue of interracial marriage; the first being that of genetics, which indicated that blacks were evolutionarily inferior to whites. In the doctor's words, the Negroes were a "younger race” as evidenced by their lack of historical accomplishments in science or the arts, remaining in a "mud hut culture" over the millennia while Europe produced its cathedrals, and Renaissance art. ${ }^{129}$

Dr. Garrett also expressed his concerns over more recent issues involving the emergence of six independent African republics, about which he noted that Africans were apparently not ready for because of their tendency toward dictatorship. This was not to be unexpected, the doctor believed, because “semi-savage people” were “custom to a tribal government.” Morphew made it a point to clarify in a question to Dr. Garrett that the discussion was not about racial inferiority or superiority but instead was focused on,

...the adaptation of one race to a culture which is primarily a middle-class white culture, and the adaptation must therefore be measured in middle-class white terms, and you are saying, are you not, that there are differences between the races which would mitigate against the probability of the Negro being able to readily adapt to a middle-class white culture? ${ }^{130}$ 
The doctor confirmed Morphew’s clarification stating that, "That was my point exactly, not that the Negro is generally inferior. We know that physically the Negro is a good animal, and I don’t mean that in a derogatory way.” Garrett used African-American sports figures, such as Cassius Clay (Mohammed Ali) and Joe Lewis, as an illustration of the mulatto Negroes' apparent physical impressiveness but unfortunate intellectual deficiency. His main point however, was that the Negro race was an immature one, lacking the essential "capability which would enable him to build a technical civilization,” which the Negro has failed to accomplish in his history. ${ }^{131}$

Another manifestation of black inferiority mentioned by the doctor was that of psychology, where intelligence tests demonstrated a consistent underachievement in general education and other aptitude measurements. Black students, according to Garrett, could only advance when teachers exhibited sympathy and lowered educational standards; and that since blacks had nothing to contribute to America because of their inferiority, integration in education would result in "a breeding down or a degrading of the schools in order to accommodate these low caliber people.” The doctor also cited various examples in places like Brazil, Cuba and Puerto Rico, where interracial breeding had been occurring and where racial stratification in those societies still resulted in an exclusive white political leadership overseeing the responsibility of governing authority. ${ }^{132}$

Discussing racial differences in intelligence test scores, Morphew asked the doctor to address the criticism of those who suggested that in fact it was the social condition which produced the social inferiority of blacks as manifest in poor intelligence test scores. Dr. Garrett responded by noting the persistence of Negro academic mediocrity despite the suggestion of these critics. He also pointed out that relatively affluent and successful black people who were perhaps better off than many other white people "are those that are virtually white because of their admixture of white ancestry.” The doctor dismissed the environmental argument about the social 
inferiority of black people as being "more of a rationalization or an excuse than is a reason.” Morphew asked the doctor to clarify whether differences in intelligence between blacks and whites were a "provable demonstrable fact," to which the doctor confidently asserted in the affirmative that consistent results of multiple experiments prove the same conclusion that blacks are mentally inferior to whites. He cited aptitude tests during the First and Second World Wars and the Korean War, where there were some instances in which blacks had performed better than whites. However, the doctor clarified that a significantly greater proportion of Negroes cannot outperform whites in mental or intelligence tests. ${ }^{133}$

When Morphew asked whether the doctor was concerned about those who may interpret his assertions in a way that was unkind and impolite, he emphasized the importance of telling the truth and refuting falsehoods especially against the moralistic equalitarianism of clergy who wanted to exploit Negroes by placing upon them expectations beyond their inherent natural capabilities. The doctor also mentioned the daily indignities that Negroes would almost certainly endure living in a society as envisioned by the integrationists. Garrett also went into a legal aspect of why interracial marriage was undesirable. Though some may make a legal argument in favor of blacks and whites having a right to intermarry, the doctor explained, “...a state, a community has a right to protect itself in various ways.” He illustrated his argument by pointing to incest as socially undesirable alongside other presumably repugnant and detrimental forms of behavior such as,

...those who are criminal, who are insane, who are feebleminded, or those who are aberrant in certain ways that is not typical; and while one doesn't have to put the nigger in that category, you can say it's inadvisable and not wise, it's not desirable. Like it or not this is a European civilization, a white man's civilization, and it should remain that with the Negroes considered to be more or less guests and not to change it to a African-American civilization. ${ }^{134}$

Finally, host Morphew also asked the doctor to comment on the children of interracial marriages, which the doctor spoke out against and suggested that such unions would only be 
between the lowest classes of whites and blacks. Garrett however did mention that college students and other "intelligent and promising people” were being increasingly exposed to the philosophy of equalitarianism, which was influencing their poor decision to "destroy their future usefulness to the United States and to the American culture generally by these ill-advised marriages.”135

On another show, Dr. Robert Kuttner was the guest. As noted, Dr. Kuttner retained a Ph.D. in zoology, and was an instructor in the sciences at Clayton University in Omaha, Nebraska; and served as president of the International Institute for the Advancement of Ethnology and Eugenics. Host Morphew also pointed out that Dr. Kuttner had testified in a school case before a federal court in Jackson, Mississippi in his effort to demonstrate, “...that there are valid racial differences between groups of white and Negro children which would make it advantageous to provide separate educations for these groups of children.” After being asked by Morphew about his particular contribution to the testimony, the doctor noted that there were indeed particular "genetic components in behavior, in mental function," determined by heredity and "not subject to much environmental modification” with regard to biological racial differences between whites and blacks. Kuttner's main argument was that inherited genetic factors superseded the "range of modification possible by environmental influences" that were essentially negligible in light of observed natural realities. Kuttner cited behavioral studies involving identical twins which showed that the behavioral similarities of these twins was significantly high despite their geographic and social separation which he stated, was "proof that environment has only a modest role in determining these behavioral, and personality, and intelligence factors, and that the genetic element is dominant.” These twin studies presumably were therefore illustrative of a deeply embedded genetically determined set of behaviors associated with racial groups. ${ }^{136}$ 
Morphew also asked about brain size and its correlation with intelligence capacity, and Kuttner confirmed that larger brains do indeed correspond to greater intellectual capacity, which fossil evidence and observations in natural wildlife and measurements in brain cortical layers all substantiated. The African brain, according to the doctor, had an "approximately fifteen percent thinner cortical layer," which is "the most important part so far as higher functions are concerned...” Modern studies of brain measurements, as Kuttner elaborated, also support the idea that "larger cranial capacities" are related to human intelligence. He noted that, "individuals with big brains tend to be wiser, more educable, more talented,” whereas, “...individuals with smaller brains tend to be less talented.” Morphew also asked the doctor to answer the "equalitarian theory" that pointed to "notable exceptions" of certain intelligent individuals within racial groups that are generally understood to be mentally inferior. According to Kuttner, the existence of such exceptional individuals from groups of racially inferior people does not therefore mean that these individuals, “overlap with leaders in the front group.” The doctor expressed the view that separate education was justifiable from a community perspective because of the possibility of harm and he rejected the idea that segregated institutions hurt anyone. Kuttner stated that, "In general, weighing evidence from many sciences, I would not recommend a rapid integration of schools at this time and I can see it producing harm and damage, particularly to the Negro.”137

As illustrated in the above selected examples, the Citizens' Council Forum aimed to counter the mainstream consensus that racial difference was the product of social environment. Instead, as the featured scientists reported in their understanding of the evidence, racial difference was rooted in nature. Human beings could be classified into groups according to their innate biological differences; distinctions which were inherently unequal. Whites were the evolutionary apex of humanity and Negroes existed at the very bottom of the racial hierarchy as nature produced. Racial separation, as a way to order society, was therefore not the imposition of racist ideology upon an otherwise intellectually capable black man as the Socialist-Communist 
equalitarians would have people believe. Instead, segregation was a sound policy prescription for the reality of the superiority of whites and the inferiority of blacks.

\section{SPECIAL CASES IN THE FORUM FILMS}

Organizing the voluminous Forum films into a neat and tidy narrative is a task that belies the complex range of content generated by its producers. Although there are indeed dominant themes exhibited in these programs which overlap with how this research has thus far structured the discussion on segregationist argumentation and white supremacist ideology in Cold War context, some Forum films perhaps require special treatment. This section features a few examples of noteworthy programs that at times fit with the research concepts presented but not in as simple a fashion.

For example, one may find it curious as to why the Citizens' Council would air a documentary that seems to be rather sympathetic to the notion of black suffering via their oppression by whites in America. This video seems to be focused on the plight of Negroes in the urban northern cities such as New York, and perhaps may fit best with a frame referred to here as the Northern Hypocrisy Frame, an argument made by segregationists that aimed to expose the contradictory habits of liberal-minded white northerners who rail against southern whites in their shortcomings on race relations, but yet maintain their own segregated urban neighborhoods in the North's big cities. The program covers a wide range of urban issues seemingly from a black perspective, including speeches from the Honorable Elijah Mohammed of the Nation of Islam, James Farmer of the Congress of Racial Equality, and in part one of the film there is a gathering of what appears to be black intellectuals discussing the condition of blacks in America, and how one should come to understand themselves a black person in the United States. ${ }^{138}$ 
Another documentary called, "Hell in the City of the Angels," however, does seem to be more easily classifiable under the Negro Criminality Frame within the Negro Vices Frame. Citing the date as Wednesday, August 11, 1965, the start of the video, features a helicopter overseeing smoldering structures as the result of urban racial unrest. The narrator describes how firefighters attempting to pacify the flames were prevented from performing their tasks by unruly city dwellers hurling rocks and other dangerous objects at them. The narrator in the helicopter seemed to be giving a play-by-play real-time commentary on the riotous developments including apathetic onlookers, arsonist perpetrators and even individuals taking shots at the helicopter itself. The video also features police officers apprehending presumably violent perpetrators. One television reporter noted how officers were surrounded by rioters and that the report of an incident perhaps may have been false information sent in by some individual in order to "lure police into the area,” presumably to ambush them. Acting Governor Glenn Anderson of the state of California is shown issuing a proclamation declaring a state of emergency over Los Angeles County with a curfew in effect. Video footage of the Watts riots seems to serve the purpose of facilitating the Citizens' Council narrative of the savage Negro set free from the necessary restraint of southern segregation engaging in and displaying his natural inclination towards instability by way of urban unrest in the big, supposedly enlightened, liberal cities. ${ }^{139}$

A documentary by Dr. Houston Smith called, “The Race Problem” was featured on the Council's Forum. After acknowledging the problem of race throughout the entirety of America's history and the difficulty of finding a solution, Dr. Smith began his film with the subject of Little Rock, Arkansas and noted the grass-roots activities of Citizens' Councils and “militant Negroes.” The first interview featured Harry Ashmore, who gave his assessment of race relations in America, noting the trend toward greater inclusion of blacks in the enjoyment of democratic rights and privileges, and that southerners suffered from conspiratorial delusions with regard to civil rights organizations such as the NAACP. Ashmore advocated confronting the harsh reality 
that, "the Negro is primarily a slum dweller in the United States, rural or urban, and this is just as true in the North as it is in the South,” and that therefore their inferiority was economic, social and cultural, and particularly educational underachievement. He did however note the growing middle class intellectual Negro leadership as a ray of hope in the otherwise dismal conditions of blacks in America. Ashmore explained that the greatest pressure for change to the racial status quo was in the northern cities among the "upper strata” of the Negro populations as opposed to the "lower strata" of Negro dwellers in the South. ${ }^{140}$

After interviewing Ashmore, Dr. Smith journeyed to Mississippi to interview William J. Simmons whom he described as, "the most articulate voice of the conservative South.” When asked what he thought was at the root of the problem, Simmons attributed its origins to the ageold historical problem of two races occupying the same geographic area and the present-day activities of interracial pressure groups. Simmons advocated for the "complete physical separation of the two different ethnic groups" and "Negro repatriation" as the ultimate solution to the race problem. Negroes would be sent back to Africa and have a homeland for themselves, which Simmons felt there was greater support among the Negro population for. He acknowledged that there was a current trend toward integration but that a counter movement particularly in the South, but also in the North, was developing among white Americans as a by-product of the increasing pressure by minority groups. ${ }^{141}$

When asked if he believed all men are created equal, Simmons stated he certainly did not subscribe to the notion and that, “it's very apparent that they're not created equal. There are no two people alike.” When Dr. Smith asked for clarification about whether or not there existed differences of inferiority and superiority between racial groups, Simmons answered that, ...in certain physical characteristics I think it's quite plain that the Negroes as a group are superior. I think their production of boxing champions for example, is a case in point. Probably their ability at racing or sprinting, especially as distinct from long-distance runners, seems to certainly bear this out. In other areas I think the evidence points to certain lacks on the Negroes’ part as a race. ${ }^{142}$ 
Simmons added that, "throughout history and throughout the United States in our present stage, wherever the colored people are found as a group they're at the bottom.” He dismissed social and economic explanations for Negro inferiority, explaining that the notion that they "have been deprived of certain advantages," according to Simmons, was an excuse, and that in an open and free competitive society it was "a matter of individual accomplishment." Simmons noted that Mississippi Negroes indeed had "equality before the law" and were permitted to pursue their economic interests within the same limitations as everyone else in Mississippi society. ${ }^{143}$

When asked about "adverse international effects to our racial situation here in America," Simmons noted that he was not interested in integrating the races in the United States in order to please international opinion such as “Red China” and “caste-ridden India,” and noted that the integrationist newsprint media acted as spokesman organizations for civil rights groups by exaggerating conditions in the South and putting pressure on southern whites interested in maintaining segregation. On the question of the morality of the segregationist position and whether it was compatible with the notion of brotherly love as understood in Christian New Testament theology, Simmons noted that, "the fatherhood of God and the brotherhood of man is a spiritual concept" of "very recent origin" and that the Bible had not changed over the generations from what the Founders envisioned at the start of the country. When asked for clarification as to whether his position could be characterized as a white supremacist one, Simmons expressed discomfort with such a term stating that,

I don't like that term, I think it's a loaded term. I think it has connotations that are very unpleasant. If by white supremacy you mean a situation of oppression, or exploitation, no I would not be, and many of us, I would say the vast majority of people in our part of the country do not hold that view. However, when you turn it around and look at it the other way, we certainly would not be in favor of black supremacy and that, Dr. Smith, is what we feel is at issue in the present circumstances. ${ }^{144}$ 
As noted in previous chapters, the above argument made by Simmons is an often defensive argument made by segregationists who derive their views from white supremacist ideology but express discomfort with being characterized as white supremacist in their support for the maintenance of a segregated social order which denies to black southerners equality before the law and full enjoyment of American democratic privileges. It is, of course, a disingenuous position contradicted by the voluminous pages of the Citizens’ Councils’ official paper, and magazine which Simmons was editor for. The Council paper, as described in the previous chapter, provides countless statements and speeches expressed about the supposed natural, inherent inferiority of Negroes; and that blacks are therefore unfit for self-government. This all points to the idea of whites as superior beings, a more advanced form of humanity from that of the Negroes who had not, whether by nature or by God, been gifted the particular superior intellectual and other higher functioning characteristics which defenders of segregation, such as Simmons, consistently expressed in their views. ${ }^{145}$

\section{CONCLUSION}

This chapter provided a qualitative content analysis of the Citizens’ Council broadcast media called, Citizens' Council Forum. As a right-wing, conservative social movement protest organization in the post-Second World War era, the Council was a decidedly anti-Communist organization as exhibited in the Forum films. Featured program guests engaged in sophisticated anti-Communist critiques of U.S. foreign policy while advancing a segregationist agenda that extended beyond the geographic confines of the American South. These commentators, which included political figures at the local and national level, foreign dignitaries, military experts, scientific thinkers, and prominent grassroots activists, all contributed to a propaganda campaign against perceived un-godly forces of change in America. The frame constellation conceptual template developed in this and in previous chapters will be carried forward in the next chapter, which returns to the propaganda literature of the Citizens' Council in the form of its magazine. 
CHAPTER V: COLD WAR GEOPOLITICAL FACTORS IN SEGREGATIONIST RHETORIC

\section{THE SIGNIFICANCE OF GEOPOLITICS IN CCA RHETORIC}

The previous two chapters provided a qualitative discussion of two major pieces of Citizens’ Council propaganda media: 1) the official paper of Citizens' Council, The Citizens’ Council (1955-1961) and, 2) the broadcast series, Citizens’ Council Forum (1955-1966). In those chapters the goal was to make sense of the vast rhetoric and symbolism of the CCA propaganda media campaign by developing a coherent conceptual framework as guided by frame theory. To accomplish this task I developed the frame constellation concept discussed in detail in chapter two and carried forward in the qualitative chapters that followed. The goal in this final chapter is to understand what determines how protest movements deploy propaganda rhetoric. The major argument here is that geopolitical factors, defined as specific geographic contexts in which sociopolitical issues are situated and from which propaganda rhetoric is deployed, are influential determinants. Since protest movement rhetoric reflects its larger ideological orientation, movement ideology is also influenced by geopolitical factors. To clarify, this is not a structural analysis of factors that give rise to protest movements. Instead, this is an attempt to provide empirical confirmation of the broad idea that conservative right-wing movements rely on a central intellectual logic for collective action which is structured by complex frame messaging in their deployment of grievance rhetoric. More specific to the post-WWII segregationist era of mobilization, white southern activists relied on a historically deep-rooted system of ideas which incorporated more modern geopolitical concerns.

As first noted in the introductory chapter, in contrast to Skrentny’s (1998) claim that “Local audiences in the Deep South States tended not to be concerned with world opinion or with equal-rights issues,” I argue that southern segregationists were not parochial in their political orientation with regard to the civil rights revolution that challenged the southern racial social 
order. The scope of their concerns had a much broader focus that needs to be contextualized in at least three geopolitical scales; southern local and regional issues, broader national-domestic issues, and even larger international-global issues. These geopolitical contexts though separated out in this chapter for analysis, in reality fit together to reflect the degree to which prosegregationists understood the gravity of the threat: that the white South was at the center of a struggle for the preservation of the civilized, free world.

The geographic context of protest frames is important to consider because it is a useful way to get at the varying degrees of geopolitics that define the propaganda messaging of a protest movement. Some movements are more narrowly focused on effecting change within the scope of local issues, whereas as others may have a much larger reach in their protest rhetoric. This research features a movement that emerged in opposition to another movement which had already come to define and be shaped by larger international issues. Although the post-WWII black freedom struggle had its foundations in local activism throughout the South, it developed into a movement with international ramifications to the degree that the United States government concerned itself with how the Soviet Union and other detractors could use deplorable race relations in America as effective propaganda tools. Civil rights activists were fully aware of America's sensitivities to the Cold War geopolitical stakes of their protest campaigns, but so too were white southern pro-segregationists. This chapter is therefore an attempt to provide quantitative insights into the degree to which segregationist activists deployed their frames of protest beyond the scope of southern local and regional concerns to reflect their sophisticated awareness of larger national and international geopolitical issues relevant to their cause for collective action.

In the sections which follow, I first provide technical specifications of each of the CCA data sets subject to the analysis, then a description of the methods and a presentation of results and discussion. The second half of the chapter is a comparative analysis of segregationist protest 
rhetoric by another grassroots organization, the Ku Klux Klan, and two pieces of political elite data; the Southern Manifesto and the filibuster against civil rights legislation by Strom Thurmond. The chapter ends with a conclusion that summarizes the major findings in the entire research and possible future application of the frame constellation concept in other analyses of protest movement rhetoric and ideology.

\section{DATA SPECIFICATIONS}

Before discussing the quantitative insights, it is necessary to provide some technical information about the data. For The Citizens' Council (1955-1961), there are 24 digitized files. They are publicly available for download. ${ }^{146}$ The vast majority of these files are of mostly decent visual quality in terms of readable text, but there are many that pose a serious challenge to coding analysis. The Mississippi Department of Archives and History provided me with DVD copies of the entire collection of the Citizens' Council Forum films (1955-1966), the list for which can be viewed on the website in its special collections section. Most of these films are in good audiovisual quality but a small number have gaps either in sound, video or both. The vast majority of these programs are approximately fifteen minutes each, with some exceptions being special documentaries lasting 20 to 40 minutes, or some programs being divided into multiple segments depending on how one counts them as separate programs. For analysis in NVIVO, 131 separate digital MP4 files were uploaded. ${ }^{147}$

Although no qualitative discussion is provided for this third data set, the official journal of the Citizens' Council, The Citizen (1961-1979), will also be included in the quantitative insights presented in this final chapter. The Citizen was downloaded page-by-page from the University of Mississippi Libraries Digital Collections ${ }^{148}$ but needed to be reconstructed into complete single PDF digital booklet files as they would appear in hardcopy form. When reconstructed in this way for analysis in NVIVO there are 50 digitized files, which is probably 
not a complete collection of this data set as they were when originally published in hard copy form.

\section{METHOD OF ANALYSIS}

\subsection{Selection of Sample for Analysis}

This analysis centers on the question of what factors determine how protest frames are deployed. I hypothesize that the deployment of protest frames is largely determined by geopolitical factors (the specific geographic context in which they are used). This research consisted of two separate cycles of coding. In the first cycle I coded according to my frame constellation codebook (as described in chapter two); meticulously sifting through the entirety of the two data sets for any piece of discourse which fit into a particular frame code as previously described. As a sample for analysis, I selected the six highest coded main frames in the frame constellation for each of the three data sets because they represent a significant enough percentage of the entire frame constellation to answer the question of what influences the deployment of protest frames. Also, the reason for selecting only the main frames is because anytime a sub-frame or sub-topic frame is coded, the main frame from which they extend is also coded.

Taken in the aggregate, the six highest frames represent 59\% of all main frames coded in the entire frame constellation for The Citizens' Council (1955-1961). These six frames include the following: 1. Anti-Communist Frame (450 References), 2. Negro Vices Frame (360 References), 3. Anti-Socialist, Liberal, Leftist Frame (298 References), 4. States’ Rights Frame (279 References), 5. Historical Lessons Frame (181 References) and, 6. Anti-Racial Miscegenation Frame (145 References). In NVIVO, “references” means the total number of times a frame has been coded in the entire data set or sets, so that the reference aggregate for these six frames is 1713 or $59 \%$ of all the main frames that comprise the entire frame constellation. Table 1 , features the entire list of numbered main frames on the left column with the coding reference numbers in 
the right column for the CCA official paper. The six highest coded frames and their corresponding coding reference numbers are in bold type.

Taken in the aggregate, the six highest frames represent $81 \%$ of all main frames coded in the entire frame constellation for the Citizens' Council Forum (1955-1966). These six frames include the following: 1. Freedoms Frame (251 References), 2. States’ Rights Frame (135 References), 3. Anti-Communist Frame (103 References), 4. Anti-Socialist, Liberal, Leftist Frame (93 References), 5. Agitator Frame (51 References), 6. Historical Lessons Frame (28 References). The reference aggregate for these six frames is 661 or $81 \%$ of the frame constellation. Table 2 features the entire list of numbered main frames on the left column with the coding reference numbers in the right column for the CCA broadcast media. The six highest coded frames and their corresponding coding reference numbers are in bold type.

Taken in the aggregate, the six highest frames represent $63 \%$ of all main frames coded in the entire frame constellation for The Citizen (1961-1979). These six frames include the following: 1. Negro Vices Frame (246 References), 2. Anti-Communist Frame (214 References), 3. Anti-Socialist, Liberal, Leftist Frame (155 References), 4. Historical Lessons Frame (106 References), 5. Freedoms Frame (66 References), 6. Global Struggle for White Rule Frame (61 References). The reference aggregate for these six frames is 1354 or $63 \%$ of frame constellation. Table 3 features the entire list of numbered main frames on the left column with the coding reference numbers in the right column for the CCA official journal. The six highest coded frames and their corresponding coding reference numbers are in bold type.

\subsection{Coding for Geopolitical Variables}

After selecting the sample size of the six highest frames for each data set, the second cycle of coding was conducted. This involved re-coding all pieces of discourse under the six highest frame categories for all three data sets according to their appropriate geographic contexts. Treated here as independent variables, these specific geographic contexts include the following: 
1. South (Local and Regional); 2. National/Domestic U.S.; 3. Global/International; and 4. Geopolitically Untethered. For the South (Local and Regional) category the coding keywords were: South, Southern, Confederacy, Confederate States, Dixie, and any mention of any geographic region that is part of the South (especially the former Confederate States of America [Alabama, Arkansas, Florida, Georgia, Louisiana, Mississippi, North Carolina, Texas, Virginia, Tennessee, Texas] but also those former slave states that did not secede from the Union during the Civil War [Delaware, Kentucky, Maryland, Missouri, West Virginia]), including all cities and counties. For the National/Domestic U.S. category the coding keywords were America, United States, United States of America, country, nation, national, national government, federal, federal government (including three branches: legislative/Congress, judicial/Supreme Court, executive/presidency and all executive agencies and departments), and any mention of any geographic region part of the United States of America but located outside of the South including all cities, counties, states or regions such as the North, West, Mid-West, East Coast or West Coast. For the Global/International category the coding keywords were global, international, world, foreign, foreign countries, overseas, and any mention of any geographic region not part of the United States of America including all cities and other regions. Finally, any coded piece of frame discourse in the CCA media not attached to any of the above specified geographic contexts was coded as “Geopolitically Untethered.”

\subsection{Average Percentage Coverage of Geopolitical Variables for Six Frames}

After recoding all pieces of discourse categorized under the six frames for each of the three data sets according to the above described geographic contexts, I then sought to determine which of the geographic contexts these frames were most often deployed in. To begin, I acquired the "percentage coverage" for all of the separate files that comprise each of the three data sets. In NVIVO, "percentage coverage” refers to the percentage of content in a source that is coded under a particular category; in this case the four geopolitical categories previously named. The three 
data sets analyzed in this research are comprised of separate files which are treated as separate “sources” when uploaded into NVIVO for analysis. For example, The Citizens’ Council (19551961) has 24 digitized files which are treated as 24 separate sources. The percentage coverage of coding for the geopolitical variables will differ with each separate file; some files having a greater percentage of geopolitically coded content than others. Because I am interested in the percentage coverage of geopolitical coding for the entire data set, not the individual 24 files it is comprised of, I took the average of the percentage coverage for all 24 files. I applied the same logic to the other two data sets. Results for these are presented in graphs in the next section.

\section{RESULTS OF ANALYSIS}

In this research I sought to understand what factors determine how protest frames are deployed. I hypothesized that geopolitical factors are largely influential. That is, the deployment of protest frames is largely determined by the specific geographic context in which they are used. As described in the methods sections above, answering this question required going back into each of the three CCA data sets to re-code all pieces of discourse relevant to each of the six highest coded segregationist frames, according to the following geographic categories 1 . South (Local and Regional); 2. National/Domestic U.S.; 3. Global/International; and 4. Geopolitically Untethered, and testing them against the Geopolitically Untethered variable. The results of this geopolitical analysis, as featured in the graphs below, indicate that CCA segregationist frames were overwhelmingly deployed not only in a geographic context, as opposed to being geopolitically untethered, but also predominantly in the domestic U.S. context.

\subsection{Results for Data Set 1: The Citizens’ Council (1955-1961)}

As can be seen below in Figure 1, the results of this analysis show that most CCA segregationist frames have higher average percentage coverage of geopolitically coded discourse for the National/Domestic U.S. context than the other geopolitical categories, although South (Local \& Regional) context follows behind this. Going by the three highest frequently deployed 
frame arguments, the greatest of concerns for the CCA revolve around the intersection between Communism, Negro deviancy, especially criminality, and the corrosive influence of Socialism, liberalism and leftist politics in America.

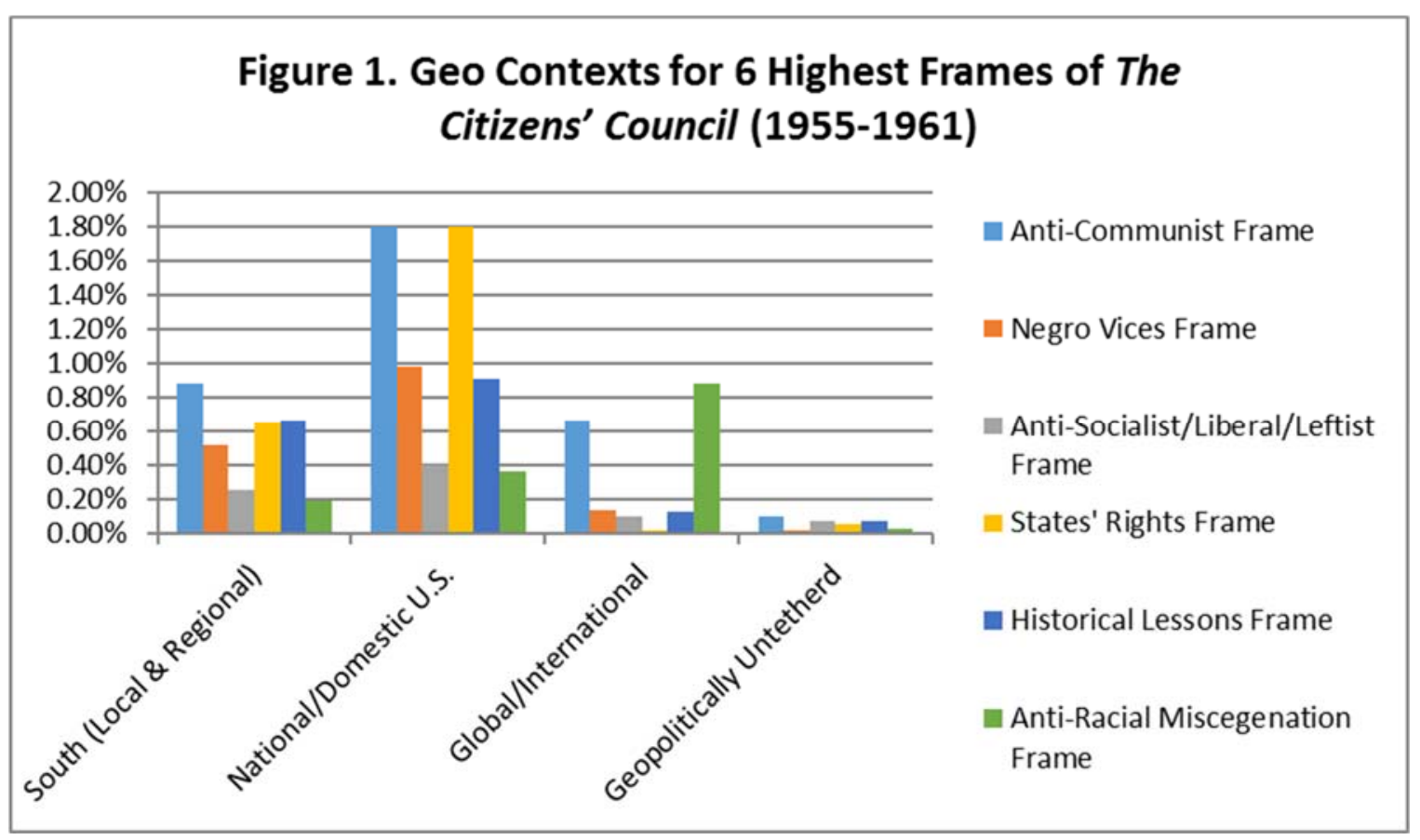

Because I am proposing a concept which treats protest movement frames not as separate pieces of propaganda rhetoric, but as part of an interlocking web of thematic arguments which comprise a frame constellation, it is therefore more appropriate to present the results in the aggregate. When aggregated (adding together the average percentage coverage for all six frames and then dividing by six), the overwhelming deployment of CCA segregationist frames in National/Domestic U.S. context can be seen more clearly. As indicated in Figure 2 below, for its official paper, CCA segregationist frame arguments were most often situated in a National/Domestic U.S., followed by the South (Local \& Regional), and then the Global/International geopolitical contexts. In the case of the CCA's official paper then, most of the segregationist frame constellation is being driven by broader national concerns. 


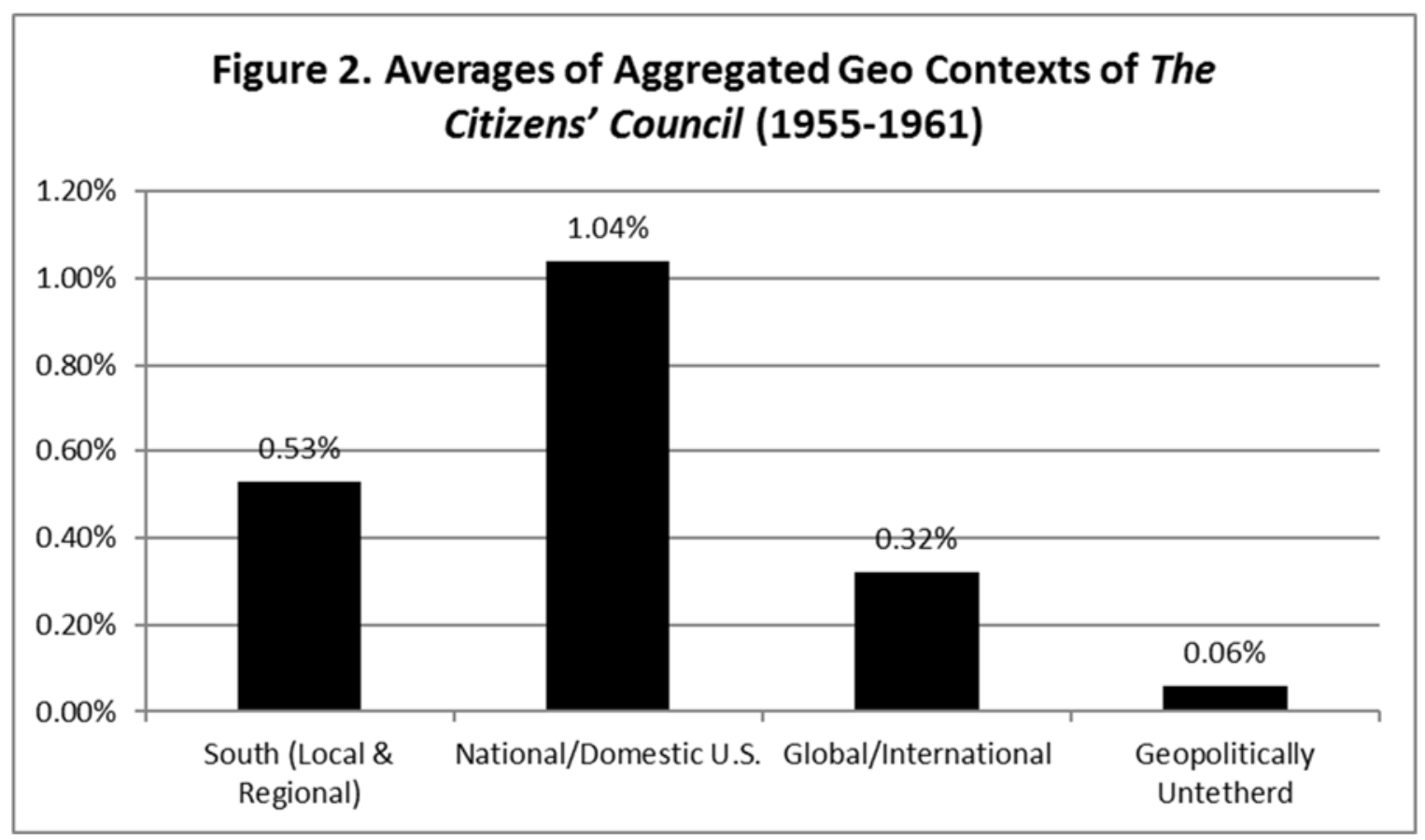

4.2 Results for Data Set 2: Citizens’ Council Forum (1955-1966)

In the disaggregated representation below in Figure 3, for its broadcast media the six highest CCA segregationist frames are most often situated in National/Domestic U.S. geopolitical context, followed by the Global/International, and then the South (Local \& Regional) contexts. The CCA Forum also displays a significant difference between the South (Local \& Regional) and Global/International contexts. 


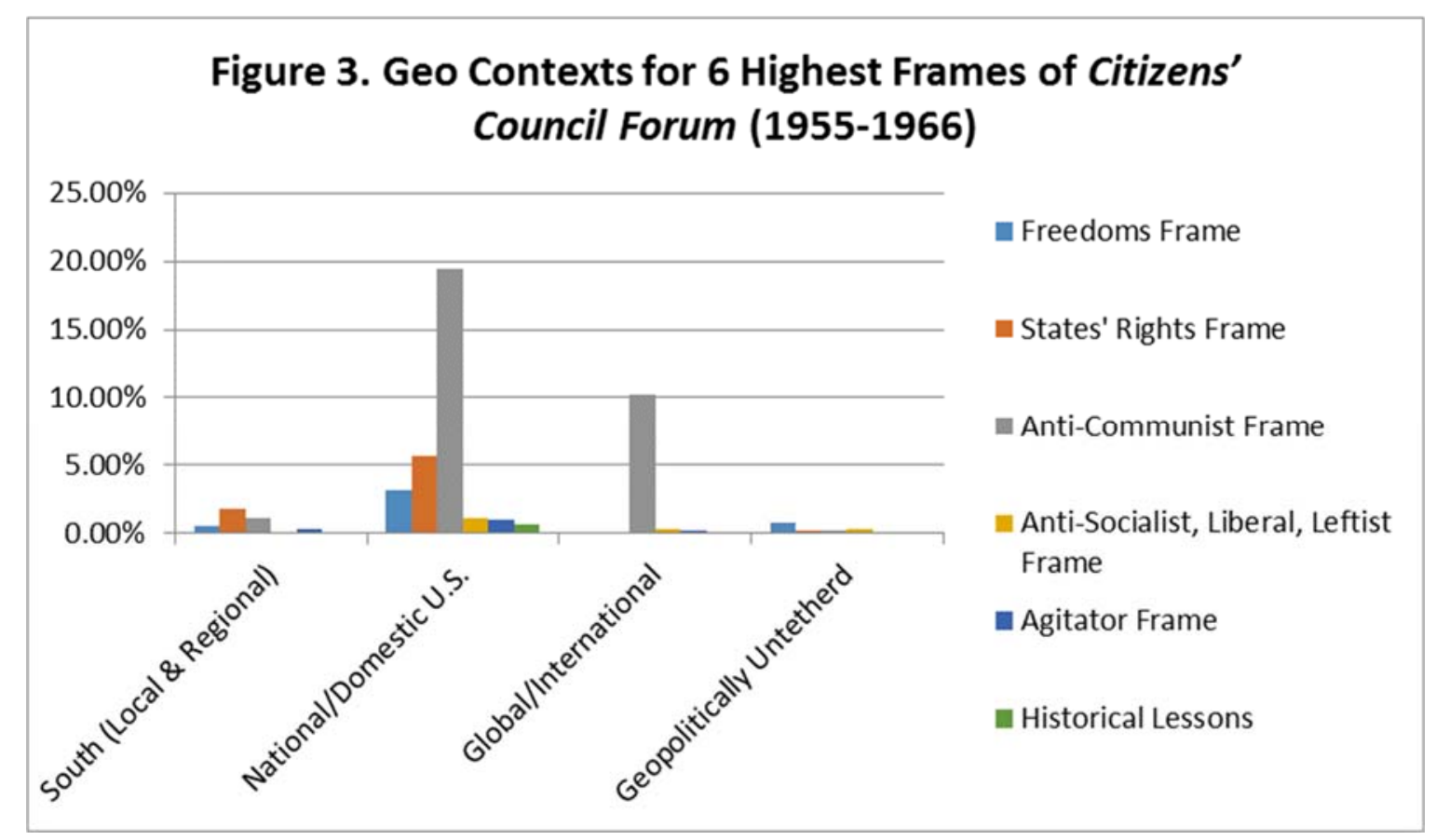

As Figure 4 below illustrates, and as indicated in the previous chapter, the broadcast media’s program content seemed to be much more focused on international developments than southern regional ones, especially with regard to U.S. foreign policy as related to the containment of Communism. Perhaps this is because the CCA Forum programs targeted a broader audience that was not limited to southern pro-segregationists. 


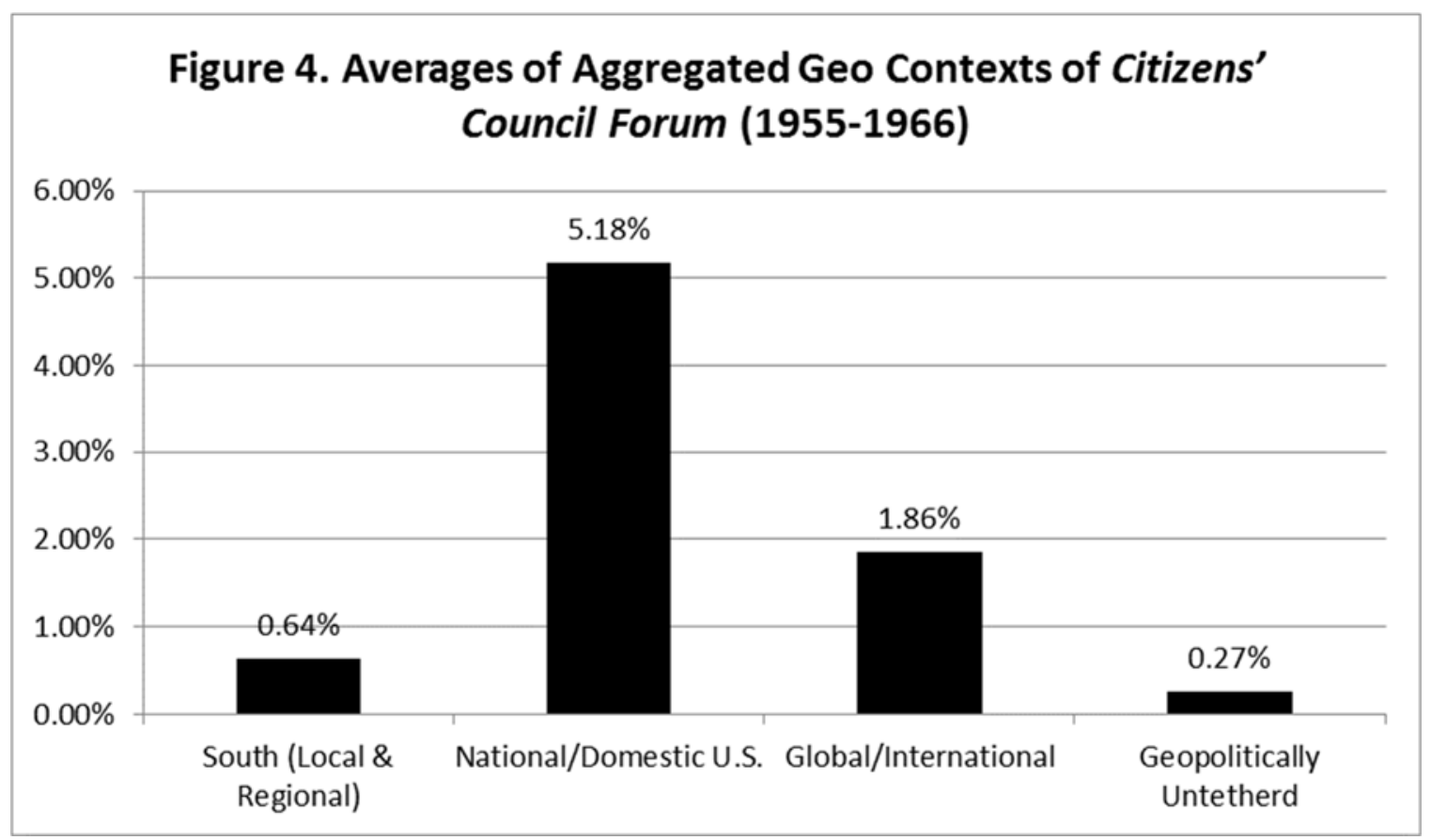

4.3 Results for Data Set 3: The Citizen (1961-1979)

Finally, for the third data set, like the first two, CCA segregationist frames are primarily deployed in National/Domestic U.S. geopolitical context. However, as in the case of the broadcast media, the CCA's official magazine journal has a significantly higher Global/International context, indicating the concerns over international developments were much greater in this period of CCA propaganda messaging. This is especially the case with the Global Struggle for White Rule frame, as can be seen in Figure 5 below. 


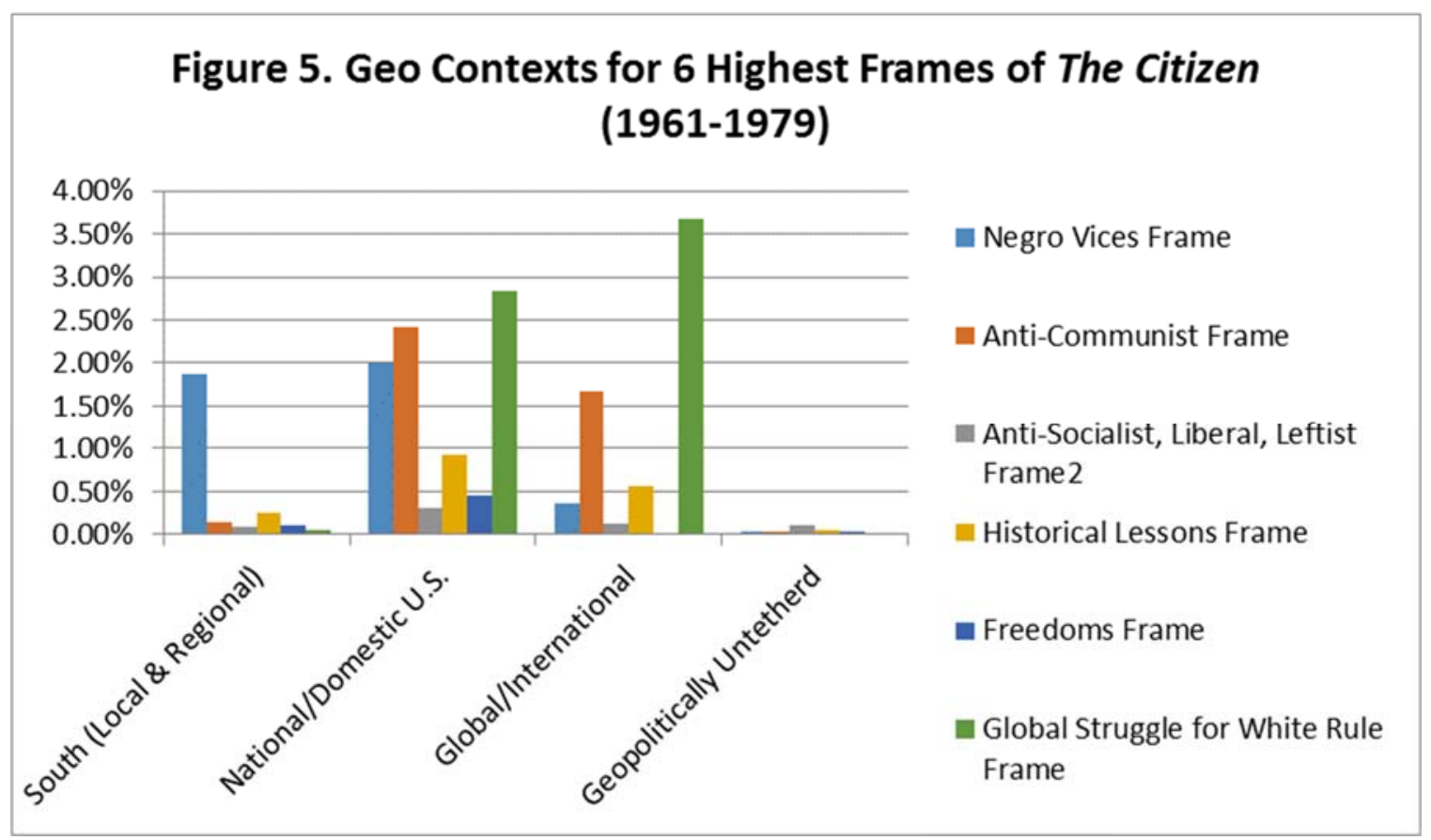

In Figure 6, the aggregated results more clearly show that this third CCA data set is similar to the results for the second data set where segregationist frames are most often deployed in the National/Domestic U.S., followed by the Global/International, and then the South (Local \& Regional) geopolitical context.

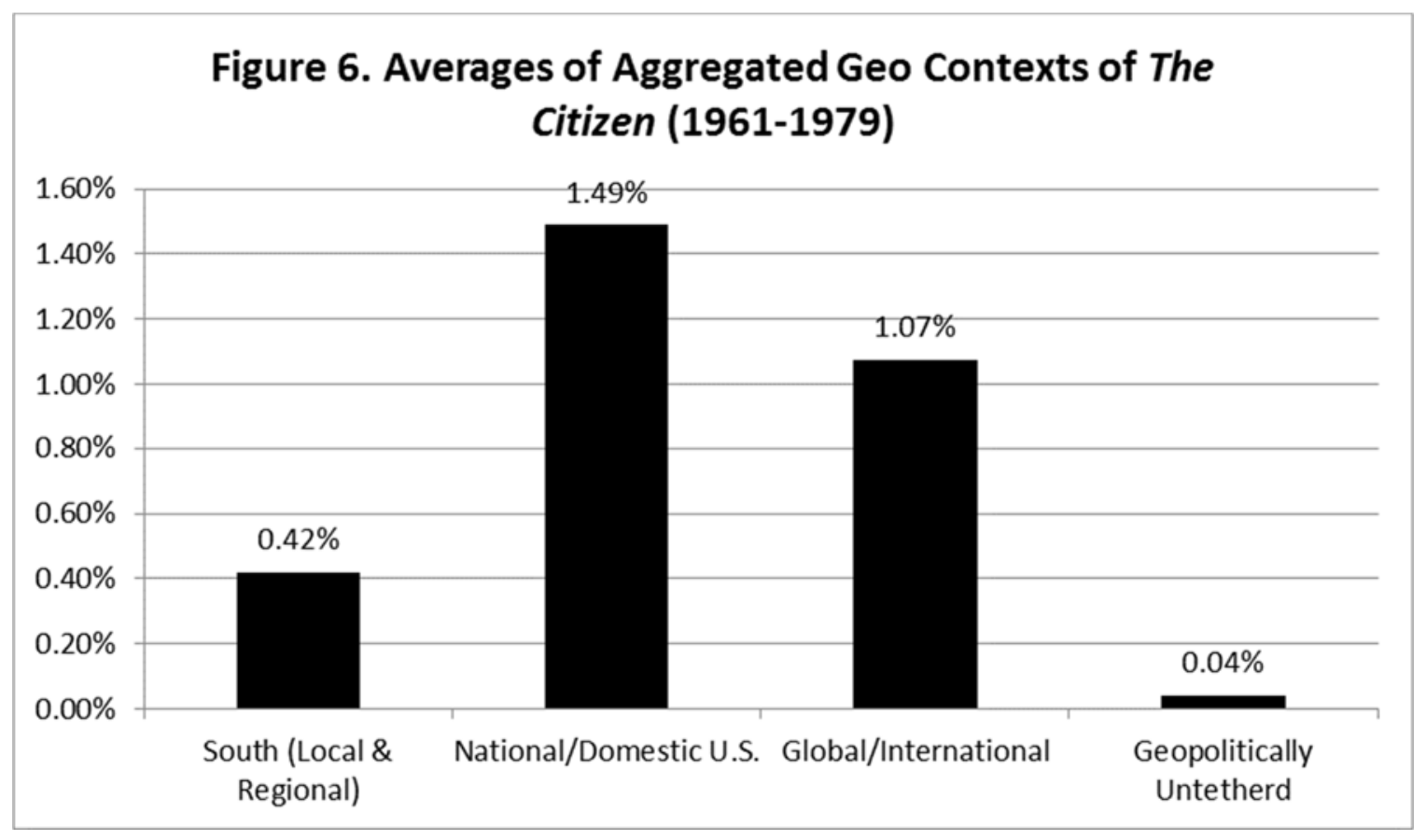




\subsection{Discussion for all Three CCA Data Sets}

Using the CCA propaganda media campaign as a single case study, I have demonstrated that southern white segregationist organizations were indeed concerned with civil rights issues in national and international context. This organization deployed frame rhetoric in ways that reflected not only southern regional fears, but especially the impact of international developments on domestic issues. From the perspective of the CCA, Cold War geopolitics abroad had a direct impact on political developments within the U.S., especially as related to the perceived infiltration of Soviet Communism into American institutions through civil rights and other similar socially liberal organizations. These groups were too susceptible to the kind of foreign influence with beliefs and practices that ran counter to the American way of life.

To what extent however, is the CCA propaganda media campaign representative of geopolitical concerns of segregationists write-large? The next section provides a comparative analysis of CCA framing to a grass-roots organization of similar ideological orientation, the 1960s Mississippi Ku Klux Klan, which was less driven by the leadership of political and business elites. This comparative analysis also includes two pieces political elite segregationist rhetoric. Following a qualitative discussion for each data set, in the next section I illustrate the geopolitical contexts of segregationist protest framing for the KKK and segregationist elites in the same manner as was done above for the CCA.

\section{COMPARATIVE ANALYSIS OF SEGREGATIONIST PROTEST FRAMING}

\subsection{Qualitative Comparison and Contrast between CCA and KKK Rhetoric}

Mississippi Ku Klux Klan literature does not appear to be as blatantly racist as the CCA media. Nor is Klan writing directly aimed at rhetorical defenses of segregation, but instead is more aimed at defending its own image as an organization. In fact, the Klan claimed to deal with racial problems, "with a minimum of inconvenience and disturbance to the general community," and had "always been against open, public violence,” and considered itself to be, “primarily a 
Christian Educational body.” 149 The Klan described itself as an organization that did not engage in violence but instead organized for the "preservation of Christian Civilization at all costs" through "self-defense", and neither was the Klan intolerant of blacks, Jews and Catholics but instead sought to defend against groups seeking to "set up a dictatorship in America which will destroy or rule the innocent, Christian White People of Mississippi.”"150

Although the Klan in some instances tried to refute the idea that it was anti-Semitic, it still issued warnings about a grand Jewish-Zionist-Communist conspiracy to rouse the Negro and force racial miscegenation upon "white women [who] will be forced to cohabit with members of the DARK RACES, the white men with black women." ${ }^{151}$ In one piece of literature, the Klan clearly states that, "Communism is Jewish,” and explains that Jews are in control of the major American media platforms and are free to bombard white America with Communist propaganda in favor of integration. ${ }^{152}$

In other instances however, Klan literature does resemble many of the complex rhetorical defenses of segregation which can be seen in the CCA media, particularly when the Klan warns about the coming age of a one world governing body under the United Nations. The Klan, like the CCA, feared the U.S. Constitution would become subservient to a new system of international laws guided by Communist tyrannical logic, foolishly aimed at bringing about racial equality through the passage of civil rights legislation in U.S. federal law. ${ }^{153}$ Like the CCA, the Klan drew fine lines between American freedom and un-American totalitarianism, especially when emphasizing the significance of localized democracy in the protection of individual freedoms. The following quote illustrates this theme in the case of the Mississippi Klan.

Mississippi is a Sovereign State in a Federal Union, and insists upon being so regarded. The communists... are all mongrelizers and supporters of totalitarian dictatorship. They despise the American concepts of Sovereignty and Individuality. They despise local self-government, and local solution of political problems, the political factors which have made America great. As long as the Free American Spirit of the People of Mississippi remains unbroken, we will be a 
source of inspiration to all Free Men everywhere. This upsets the communists. They are out to destroy America and crush the American Spirit. Mississippi is their last great political obstacle. We stand almost alone between these enemies of Christian Civilization and the Total Barbarism which is their goal for America. ${ }^{154}$

The Klan shared the CCA's grand vision of outside foreign agitators stirring up Negroes, which the Klan claimed it only sought to protect against the Un-Godly influence of Communist evil doers. The Klan did not see a genuine black movement but instead believed they were being used by foreign conspirators as evidenced by the "gestapo" tactics of the Justice Department and F.B.I in their enforcement of new civil rights laws. ${ }^{155}$ The following quote is perhaps the best example of the degree to which the KKK and the CCA shared a grand vision of how black insurrection in America was a Communist plot with the assistance of liberal-minded political leaders.

It is a lie to say that that negro riots of negro revolt occurs because he is not given a fair and equal chance in our society. Not only are they given a fair chance but there are laws that in fact favor the negro. Negro insurrections occur, not because of poverty, but rather because Communist agents, high officials, and other leading liberal government agencies have agitated the negro to think that he has been mistreated. They are now being taught to hate the white man who has for so long given all aid and assistance to the negro. ${ }^{156}$

\subsection{Quantitative Comparison and Contrast between CCA and KKK Rhetoric}

For the KKK media analysis there are 25 digitized files which are treated as 25 separate sources in NVIVO. As with all CCA data sets, the percentage coverage of coding for the geopolitical variables will differ with each separate KKK file; some files having a greater percentage of geopolitically coded content than others. Because I am interested in the percentage coverage of geopolitical coding for the entire data set, not the individual 25 files it is comprised of, I took the average of the percentage coverage for all 25 files. 
Taken in the aggregate, the six highest frames represent $76 \%$ of all main frames coded in the entire frame constellation for the various KKK literature. These six frames include the following: 1. Anti-Communist Frame (55 References), 2. Agitator Frame (19 References), 3. Religious Frame (18 References), 4. Freedoms Frame (12 References), 5. Historical Lessons Frame (12 References) and, 6. Anti-Racial Miscegenation Frame (10 References). As I did with the three CCA data sets, Table 4 features the entire list of numbered main frames on the left column with the coding reference numbers in the right column. The six highest coded frames and their corresponding coding reference numbers are in bold type.

5.3 Results for Data Set 4: Various Mississippi Ku Klux Klan literature (1960s)

As can be seen below in Figure 7, the results of this analysis show that most KKK segregationist frames have higher average percentage coverage of geopolitically coded discourse for the National/Domestic U.S. geopolitical context like the three CCA data sets.

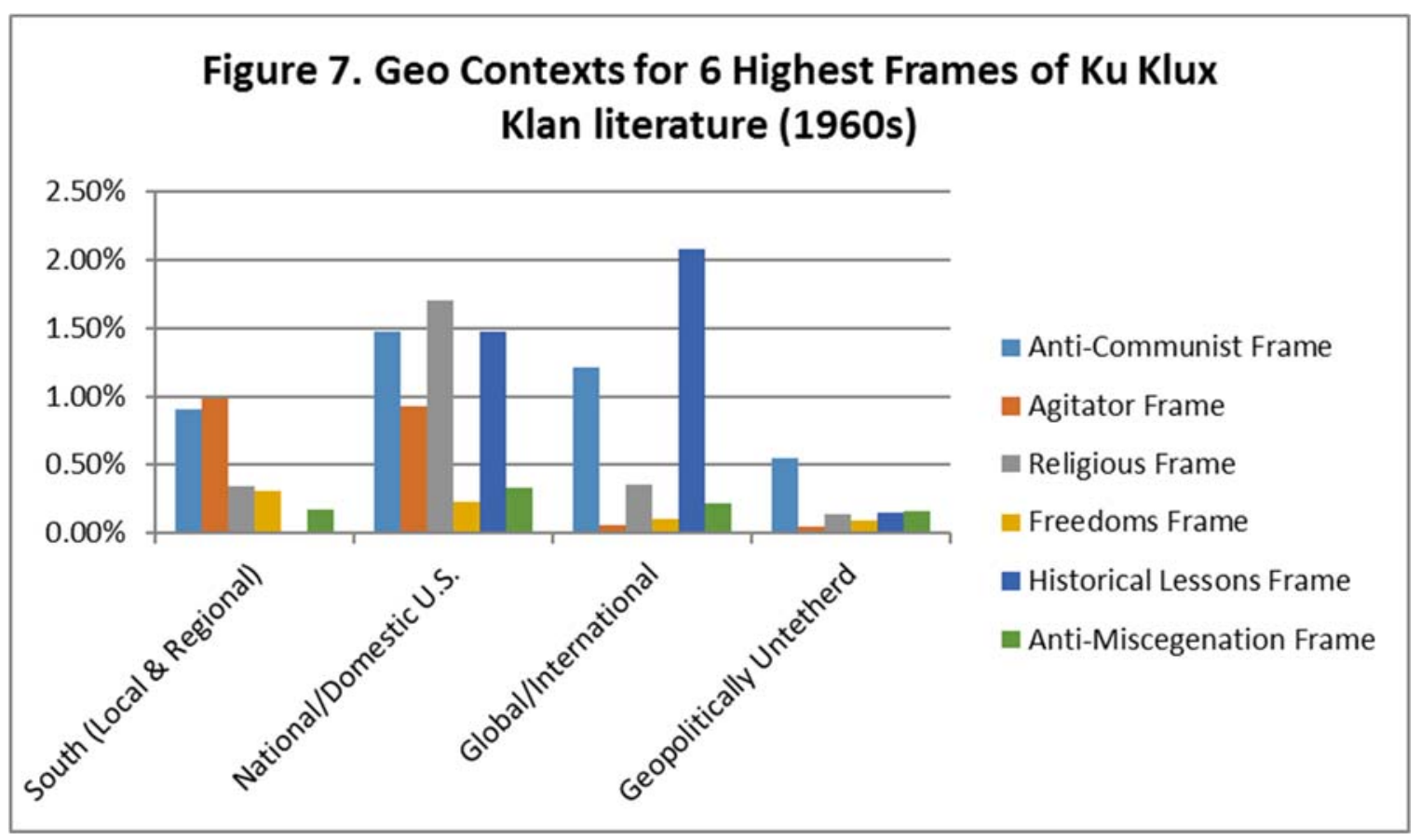

More apparent, as featured in the aggregated Figure 8 below, even the Klan literature deployed segregationist framing more in a National/Domestic U.S. and a Global/International 
geopolitical context. Southern local and regional concerns for the KKK frame constellation are not as prominent here.

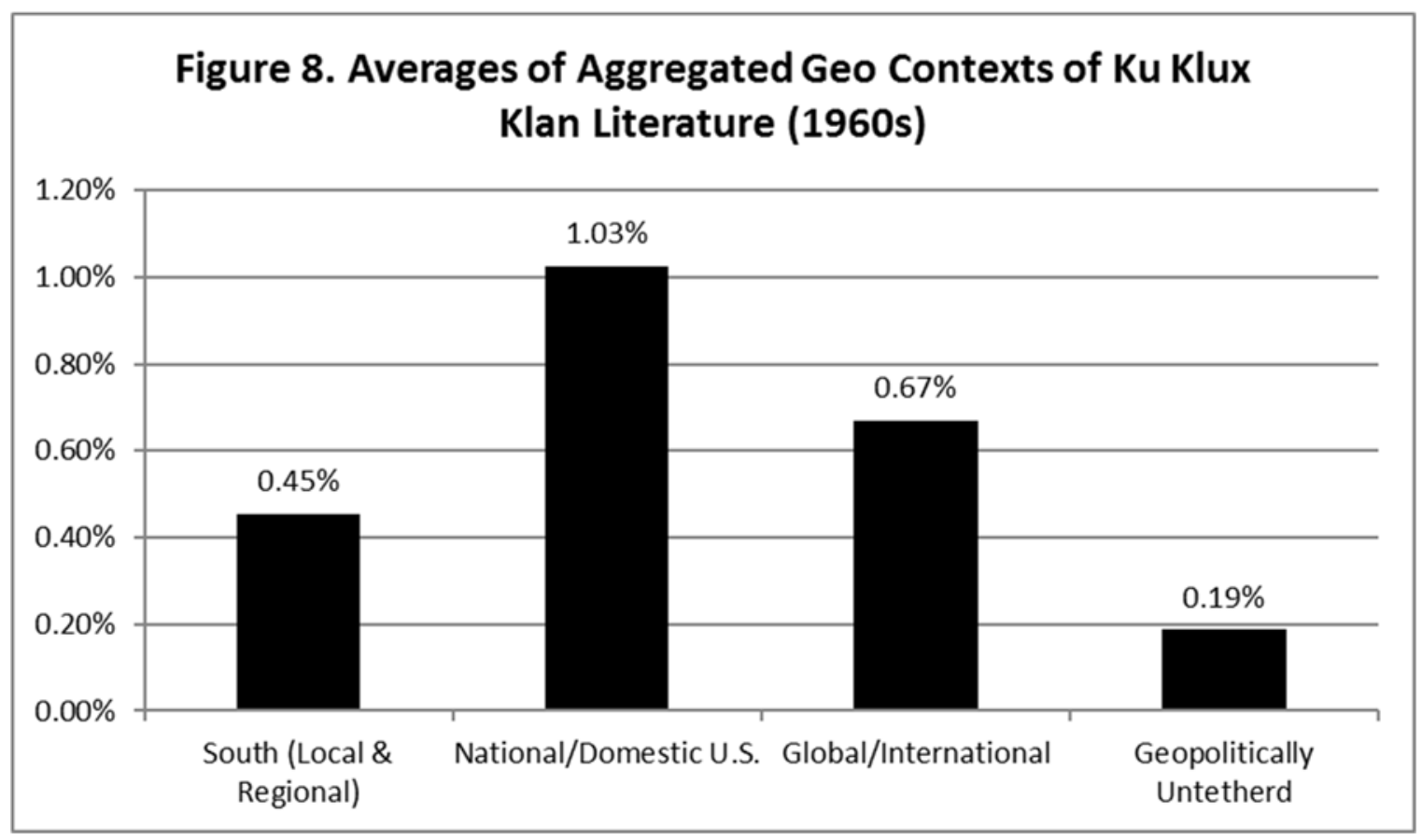

5.4 Qualitative Comparison and Contrast between CCA and Elite Rhetoric

\subsection{A. The Southern Manifesto}

The Southern Manifesto is a two to three-page political tract consisting of southern white grievances against the federal government, especially the Supreme Court's Brown decision, for its violations of state sovereignty. Although it is certainly a pro-segregationist political statement in defense of the southern white power structure, it does not exhibit the kind of overtly racist rhetoric as in the CCA or KKK's propaganda media. Instead, it is squarely focused on an articulation and defense of state's rights principles. A discussion of the historical scholarship's perspective on the Southern Manifesto is provided below.

March 12, 1956 saw the U.S. Senate release of a rhetorical statement of resistance to "outside agitators" in their effort to revolutionize southern race relations with the assistance of the federal government, especially through the courts (Woods 2004). Southern white politicians 
banded together in a show of unity by issuing the "Declaration of Constitutional Principles," more popularly known as the "Southern Manifesto," a document which only three southern senators refused to sign. The Southern Manifesto, as a singular document, became the legal intellectual basis upon which mainstream white resistance in the South would be founded (Webb 2005).

At the level of political elites, the heated climate of resistance left little room for southern moderation on the question of integration (Webb 2005). The Manifesto therefore became a strategic political tool devised by the southern congressional delegation to placate "intransigent segregationists,” who were supporters of formal defiance of the federal judiciary, and to accommodate moderate southern politicians who were essentially segregationist but could not see past the futility and irresponsibility of open defiance (Day 2014:5).

Although most historical scholars acknowledge the historical significance of the Southern Manifesto, the document itself, curiously has received little scholarly attention and has fallen into virtual obscurity in the public memory. Historians do not even agree on its author (Day 2014:3). In describing its significance, the publication of the Southern Manifesto has been characterized as “something close to a political counterrevolution” (Wilhoit 1973:51). It included ideas that drew on the South’s long past grievances which were only resurrected by the Brown decision. Having no sound legal foundation upon which to stand, and demanding no specific legislative action, the document was nonetheless "a dramatic challenge of the South's ruling oligarchs to the supremacy of federal law and authority in the states of the old Confederacy.” The main thrust of the Manifesto was its attack on Brown as an abomination and unjust usurpation of state power by misguided federal justices (Wilhoit 1973:52).

5.4B. The Strom Thurmond Filibuster: August 29, 1957

Strom Thurmond was one of the most frequent guest commentators on the Citizens' Council Forum, in his filibuster in the U.S. Senate, he did not however rely on overtly 
segregationist argumentation. Instead, Thurmond primarily deployed strict constitutional points to criticize the legislative direction toward civil rights reforms. Most of the speech discussed constitutional principles and the limits of federal law and prerogatives of the states, and the historical origins and significance of the system of government which the Founders left to future generations to protect. In fact, most of Thurmond's speech features states' rights framing as the graphs below will illustrate. Most of this rhetoric however, is not couched in an obvious prosegregationist way like CCA propaganda, which Thurmond greatly contributed to. Thurmond's target audience was perhaps much larger than southern-regional segregationists and therefore blatant racism of the sort featured in CCA media would not have served his broad purposes.

There are a few instances where Thurmond did use familiar segregationist argumentation such as the Racial Harmony Frame. He argues that passage of further civil rights legislation will only harm relations between blacks and whites and disturb the relative "good feeling existing between the white and the Negro races...” Thurmond explains that,

The Civil Rights Commission, by using its powers to attempt to force integration of the races, is bound to create suspicion and tension between the races to an even greater degree than the suspicion and tension which was created by the 1954 Supreme Court decision in the school segregation cases. ${ }^{157}$

In another instance Thurmond put forward a Protection of the Negro’s Best Interest Frame where he contends that party politics was really what the effort to pass new civil rights legislation was about, and that both parties were competing for the Negro vote but in a way that "takes away his dignity.” Thurmond explained that, "It takes away his sanctity as an individual, in which he can take pride in himself, his accomplishments and his race and not be led around like a bull with a ring in his nose." ${ }^{\prime 158}$ His major concern was that the proposed civil rights legislation was more about electoral politics to the benefit of one party over another with regard to currying favor with the "Negro vote" as it was "key [in the] industrial States in the North. ${ }^{159}$ 
On the whole however, the content of Thurmond's filibuster is mostly couched in a State’s Rights Frame, explaining that the Federal government already possessed legal authority in the matter of civil rights but failed to enforce these laws and was instead more interested in violating state sovereignty. Thurmond's filibuster does not resemble the CCA's segregationist frame constellation as there is not a direct defense of segregation or white supremacist ideology. 5.5 Quantitative Comparison and Contrast between CCA and Elite Rhetoric

For the elite rhetoric analysis there are only 2 digitized files which are treated as 2 separate sources in NVIVO. As with the CCA and KKK data sets, I am interested in the percentage coverage of geopolitical coding for the entire data set and therefore I took the average of the percentage coverage for both files. Taken in the aggregate, the six highest frames represent 86\% of all main frames coded in the entire frame constellation for the two pieces of elite rhetoric data. These six frames include the following: 1. States’ Rights Frame (24 References), 2. AntiCommunist Frame (5 References), 3. Agitator Frame (4 References), 4. Freedoms Frame (4 References), 5. Historical Lessons Frame (3 References) and, 6. Protection of Negro’s Best Interest (3 References). The reference aggregate for these six frames is 43 or $86 \%$ of all the main frames that comprise the entire frame constellation for the elite rhetoric. As I did with the CCA and KKK data sets, this information is located in Table 5, which features the entire list of numbered main frames on the left column with the coding reference numbers in the right column. The six highest coded frames and their corresponding coding reference numbers are in bold type. 5.6 Results for Data Set 5: Elite Segregationist Rhetoric

As can be seen below in Figure 9, the results of this analysis show that elite segregationist frames are overwhelmingly dominated by states’ rights framing, which also has higher average percentage coverage of geopolitically coded discourse for the U.S. Domestic Context than the other geopolitical categories. 


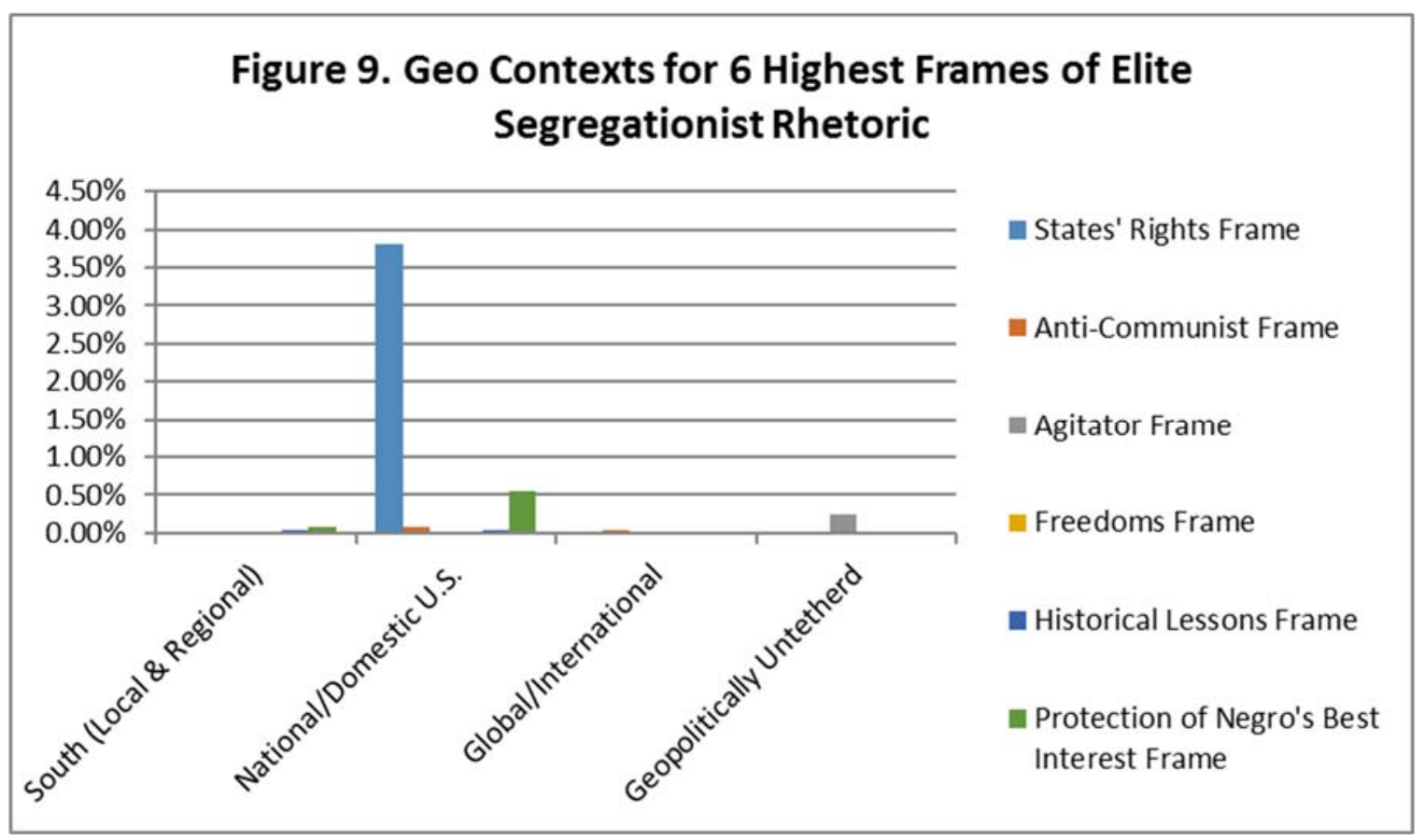

More apparent, as featured in the aggregated Figure 10 below, the frame constellation from the perspective of elite segregationist rhetoric is driven significantly by the National/Domestic U.S. geopolitical context. This should not be surprising since these U.S. politicians, though championing the cause of the white South, had to deploy rhetoric in ways that spoke to broader constitutional concerns as opposed to southern regional traditional defenses of segregation. 


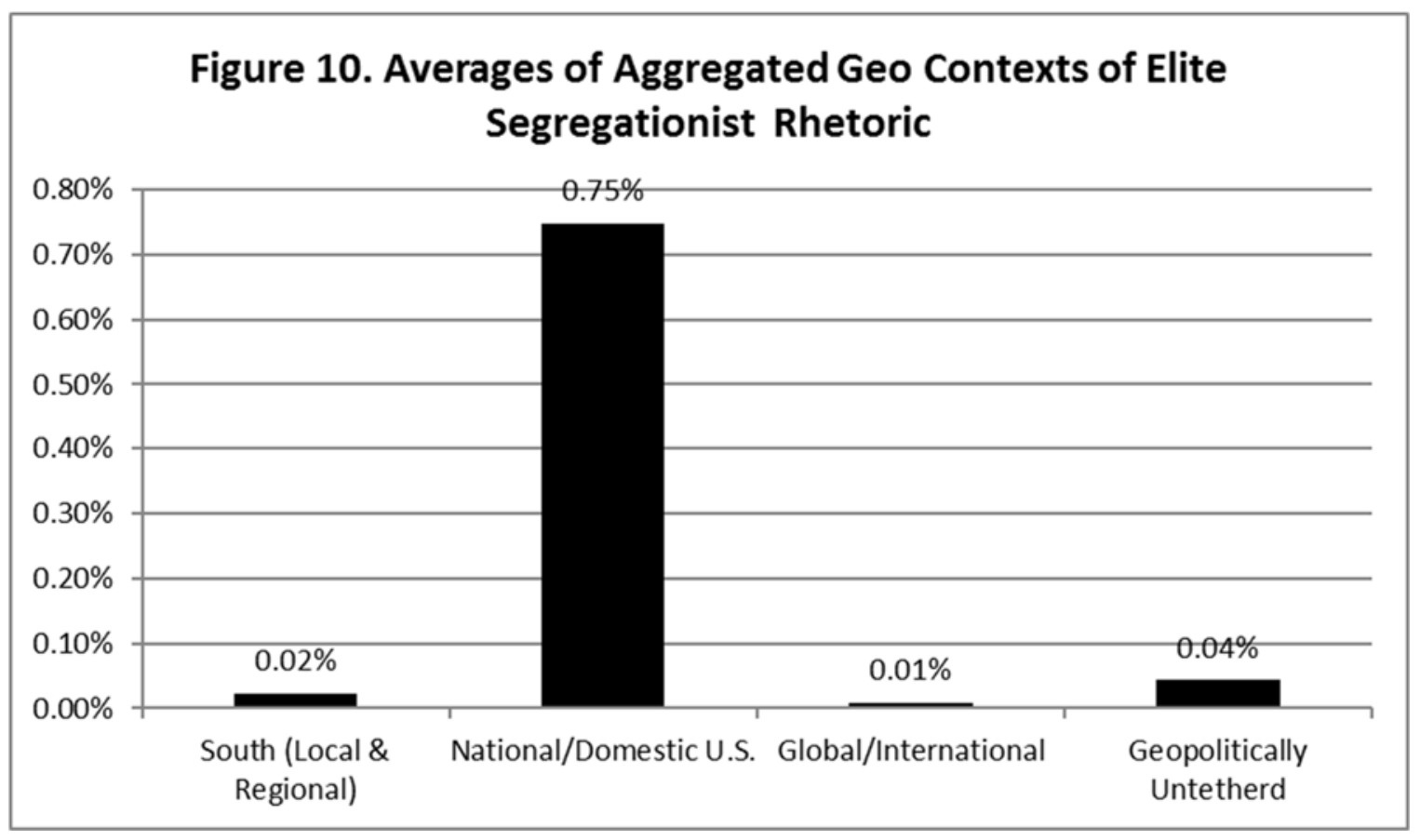

5.7 Discussion for Comparative Analysis

The results for the elite segregationist rhetoric are certainly not representative of southern white political elites write-large. Although more elite segregationist discourse is needed, the two pieces selected for comparative analysis together with the Klan rhetoric helps to broaden the sample size beyond the CCA data sets. Through comparison, the goal was to show variation in the dynamics of the frame constellation and white supremacist ideology. Both the CCA and the KKK greatly concerned themselves with national and international Cold War geopolitics. AntiCommunist frame-messaging was not incidental to, but instrumental in the deployment of the most frequently used protest frames. In this regard, both grass-roots organizations were sophisticated in their propaganda messaging, drawing on more traditional defenses of the racial hierarchy while adapting to the contemporary Cold War political ideology. As noted in the introductory chapter, conservative right-wing protest movements, though defined by racism in the case of the segregationists, should not be dismissed as mere reactionary, and purely emotionally driven. Segregationist activists relied on a system of complex notions which together structured a 
central intellectual logic for collective action. Segregationist frames of protest were deployed in ways that reflected the mainstream, modern geopolitical concerns of Cold War international affairs as having a direct impact on southern regional social developments.

\section{SUMMARY OF RESEARCH AND FUTURE POSSIBLE DIRECTIONS}

As argued and documented throughout the preceding chapters, segregationist argumentation was not merely regional in the scope of its concerns over race relations but was largely situated in national and international concerns. For the segregationist movement, their frames of protest reflected the major political issues of the Cold War-civil rights era, especially that which resonated with anti-Communism. From their perspective, at the heart of the civil rights struggle was an inauthentic, foreign-orchestrated attempt to destroy American democracy from within by stirring up black southern passions against well-meaning southern whites to result in the destruction of a mutually beneficial, and otherwise harmonious, racial hierarchy. Soviet Communists and their Socialist allies in America's leftists institutions (academia, the media establishment, the Hollywood entertainment industry, and civil rights organizations), all worked together to unseat the white man from his rightful place atop the racial pyramid, to be replaced by those unfit for stewardship over the civilized, free world.

This research examined how segregationists fused traditional frame arguments with Cold War geopolitics to defend the South’s racial hierarchy and white supremacist ideology. For protest movements, ideology's power is its capacity to weave seemingly disparate cultural perspectives of deep historical roots together with more contemporary concerns and reorient them into a web of frame arguments serving the core logic for collective action. Performing a similar frame constellation analysis as I have done here, to other similar organizations during the era of massive resistance would also enlarge the overall understanding of white supremacist ideology in that period. This would require obtaining similar propaganda media documents for content discourse analyses. Though the focus here was on white supremacist ideology and segregationist 
frames, the frame constellation concept can serve as a useful conceptual template, not limited to studies of conservative right-wing activism of the past or the present for that matter, but can be applicable to liberal-progressive/left-leaning movements and perhaps pertinent to other instances where local activism collides with geopolitics.

\section{CONCLUSION: RECTIFYING THE MASSIVE OVERSIGHT}

Though the strength of organized opposition to civil rights was a significant social phenomenon, the scholarship still has yet to treat the subject with the seriousness the civil rights movement has received. As one scholar has observed in his criticisms of historians, there exists a dramatically unbalanced research on civil rights which receives the overwhelming amount of focus while segregationists have received a comparatively minute amount of attention (Webb 2005:8). As Webb (2005:8) claims, “The comparative lack of attention bestowed on segregationists has stripped the story of civil rights protest of its proper historical context.” The voluminous scholarly attention to the black freedom struggle overshadows the relatively scant interest researchers have devoted to segregationists and their massive resistance effort. If historical research has fallen short in this regard, the weaknesses of social movement research, I contend, are far greater. As previously noted in the observations of McAdam and Kloos,

Given its intensity at the time and, more important, its significant long-term political and electoral consequences, it is remarkable to us that this movement is largely forgotten today and certainly not invoked as an important factor by those seeking to understand the political economy of the contemporary United States (McAdam and Kloos 2014:104).

This uneven scholarly treatment destroys anything approaching an appropriate context in which to understand the social upheavals that characterized the civil rights era as related to segregationist countermovement mobilization. More specific to this particular study, if, as historical scholars claim, the Citizens' Councils of America was the most potent manifestation of grassroots conservative activism in the post-Second World War era (Bartley 1969; McMillen 
1971), why have social movement researchers, particularly those who specialize in conservative right-wing movements in America, failed to address this important social movement organization? Through a comparative analysis of the ideology of massive resistance as expressed in the CCA's propaganda media campaign, KKK literature and the political elite segregationist rhetoric, this study is a first step in an attempt to rectify this massive oversight. 
TABLES

Table 1 Main Frames and Coding References for The Citizens’ Council (1955-1961)

\begin{tabular}{|c|c|}
\hline Main Frames & Main Frame Coding References \\
\hline 01 Agitator Frame & 121 \\
\hline 02 Anti-Communist Frame & 450 \\
\hline 03 Anti-Racial Miscegenation Frame & 145 \\
\hline 04 Anti-rightwing Militant Extremism Frame & 24 \\
\hline 05 Anti-Socialist, Liberal, Leftist Frame & 298 \\
\hline $\begin{array}{l}06 \text { Collapse or Destruction of Civilization } \\
\text { Frame }\end{array}$ & 26 \\
\hline $\begin{array}{l}07 \text { Discrimination Against or Anti-Whites } \\
\text { Frame }\end{array}$ & 13 \\
\hline 08 Freedoms Frame & 118 \\
\hline 09 Global Struggle for White Rule Frame & 76 \\
\hline 10 Historical Lessons Frame & 181 \\
\hline 11 Majority Opinion Frame & 51 \\
\hline 12 Nature Frame & 30 \\
\hline 13 Negro Contentment Frame & 39 \\
\hline 14 Negro intellectual Inferiority Frame & 51 \\
\hline 15 Negro Takeover-Domination Frame & 71 \\
\hline 16 Negro Vices Frame & 360 \\
\hline $\begin{array}{l}17 \text { Northern and Non-South Support and } \\
\text { Sympathy Frame }\end{array}$ & 122 \\
\hline 18 Northern Hypocrisy Frame & 49 \\
\hline $\begin{array}{l}19 \text { Protection of the Negro's Best Interest } \\
\text { Frame }\end{array}$ & 77 \\
\hline 20 Race Difference Frame & 55 \\
\hline 21 Racial Harmony Frame & 30 \\
\hline 22 Racial Preference Frame & 13 \\
\hline 23 Religious Frame & 83 \\
\hline 24 Savage African or Savage Negro Frame & 73 \\
\hline 25 Science Frame & 50 \\
\hline 26 States' Rights Frame & 279 \\
\hline $\begin{array}{l}27 \text { UN Tyranny-One World Government } \\
\text { Frame }\end{array}$ & 12 \\
\hline 28 Un-American Frame & 8 \\
\hline $\begin{array}{l}\text { SUM of } 6 \text { Highest }=1713 \text { or } 59 \% \text { of Main } \\
\text { Frames }\end{array}$ & SUM TOTALS = 2905 \\
\hline
\end{tabular}


Table 2 Main Frames and Coding References for Citizens' Council Forum (1955-1966)

\begin{tabular}{|c|c|}
\hline Main Frames & Main Frame Coding References \\
\hline 01 Agitator Frame & 51 \\
\hline 02 Anti-Communist Frame & 103 \\
\hline 03 Anti-Racial Miscegenation Frame & 4 \\
\hline 04 Anti-rightwing Militant Extremism Frame & 3 \\
\hline 05 Anti-Socialist, Liberal, Leftist Frame & 93 \\
\hline $\begin{array}{l}\text { 06 Collapse or Destruction of Civilization } \\
\text { Frame }\end{array}$ & 2 \\
\hline $\begin{array}{l}07 \text { Discrimination Against or Anti-Whites } \\
\text { Frame }\end{array}$ & 1 \\
\hline 08 Freedoms Frame & 251 \\
\hline 09 Global Struggle for White Rule Frame & 3 \\
\hline 10 Historical Lessons Frame & 28 \\
\hline 11 Majority Opinion Frame & 5 \\
\hline 12 Nature Frame & 8 \\
\hline 13 Negro Contentment Frame & 3 \\
\hline 14 Negro intellectual Inferiority Frame & 5 \\
\hline 15 Negro Takeover-Domination Frame & 0 \\
\hline 16 Negro Vices Frame & 12 \\
\hline $\begin{array}{l}17 \text { Northern and Non-South Support and } \\
\text { Sympathy Frame }\end{array}$ & 18 \\
\hline 18 Northern Hypocrisy Frame & 5 \\
\hline $\begin{array}{l}19 \text { Protection of the Negro's Best Interest } \\
\text { Frame }\end{array}$ & 19 \\
\hline 20 Race Difference Frame & 3 \\
\hline 21 Racial Harmony Frame & 11 \\
\hline 22 Racial Preference Frame & 3 \\
\hline 23 Religious Frame & 11 \\
\hline 24 Savage African or Savage Negro Frame & 8 \\
\hline 25 Science Frame & 20 \\
\hline 26 States' Rights Frame & 135 \\
\hline $\begin{array}{l}27 \text { UN Tyranny-One World Government } \\
\text { Frame }\end{array}$ & 9 \\
\hline 28 Un-American Frame & 6 \\
\hline $\begin{array}{l}\text { SUM of } 6 \text { Highest }=661 \text { or } 81 \% \text { of Main } \\
\text { Frames }\end{array}$ & SUM TOTALS $=820$ \\
\hline
\end{tabular}

Table 3 Main Frames and Coding References for The Citizen (1961-1979)

\begin{tabular}{|l|l|}
\hline Main Frames & Main Frame Coding References \\
\hline 01 Agitator Frame & \\
\hline
\end{tabular}




\begin{tabular}{|c|c|}
\hline 02 Anti-Communist Frame & 214 \\
\hline 03 Anti-Racial Miscegenation Frame & 39 \\
\hline 04 Anti-rightwing Militant Extremism Frame & 1 \\
\hline 05 Anti-Socialist, Liberal, Leftist Frame & 155 \\
\hline $\begin{array}{l}06 \text { Collapse or Destruction of Civilization } \\
\text { Frame }\end{array}$ & 12 \\
\hline $\begin{array}{l}07 \text { Discrimination Against or Anti-Whites } \\
\text { Frame }\end{array}$ & 43 \\
\hline 08 Freedoms Frame & 66 \\
\hline 09 Global Struggle for White Rule Frame & 61 \\
\hline 10 Historical Lessons Frame & 106 \\
\hline 11 Majority Opinion Frame & 24 \\
\hline 12 Nature Frame & 10 \\
\hline 13 Negro Contentment Frame & 0 \\
\hline 14 Negro intellectual Inferiority Frame & 52 \\
\hline 15 Negro Takeover-Domination Frame & 13 \\
\hline 16 Negro Vices Frame & 246 \\
\hline $\begin{array}{l}17 \text { Northern and Non-South Support and } \\
\text { Sympathy Frame }\end{array}$ & 21 \\
\hline 18 Northern Hypocrisy Frame & 4 \\
\hline $\begin{array}{l}19 \text { Protection of the Negro's Best Interest } \\
\text { Frame }\end{array}$ & 20 \\
\hline 20 Race Difference Frame & 40 \\
\hline 21 Racial Harmony Frame & 19 \\
\hline 22 Racial Preference Frame & 14 \\
\hline 23 Religious Frame & 27 \\
\hline 24 Savage African or Savage Negro Frame & 41 \\
\hline 25 Science Frame & 51 \\
\hline 26 States' Rights Frame & 41 \\
\hline $\begin{array}{l}27 \text { UN Tyranny-One World Government } \\
\text { Frame }\end{array}$ & 3 \\
\hline 28 Un-American Frame & 2 \\
\hline $\begin{array}{l}\text { SUM of } 6 \text { Highest }=661 \text { or } 81 \% \text { of Main } \\
\text { Frames }\end{array}$ & SUM TOTALS =1354 \\
\hline
\end{tabular}

Table 4 Main Frames and Coding References for Ku Klux Klan literature (1960s)

\begin{tabular}{|l|r|}
\hline Main Frames & Main Frame Coding References \\
\hline 01 Agitator Frame & 19 \\
\hline 02 Anti-Communist Frame & 55 \\
\hline 03 Anti-Racial Miscegenation Frame & $\mathbf{1 0}$ \\
\hline 04 Anti-rightwing Militant Extremism Frame & 0 \\
\hline
\end{tabular}




\begin{tabular}{|c|c|}
\hline 05 Anti-Socialist, Liberal, Leftist Frame & 6 \\
\hline $\begin{array}{l}06 \text { Collapse or Destruction of Civilization } \\
\text { Frame }\end{array}$ & 1 \\
\hline $\begin{array}{l}\text { 07 Discrimination Against or Anti-Whites } \\
\text { Frame }\end{array}$ & 1 \\
\hline 08 Freedoms Frame & 12 \\
\hline 09 Global Struggle for White Rule Frame & 0 \\
\hline 10 Historical Lessons Frame & 12 \\
\hline 11 Majority Opinion Frame & 0 \\
\hline 12 Nature Frame & 1 \\
\hline 13 Negro Contentment Frame & 0 \\
\hline 14 Negro intellectual Inferiority Frame & 2 \\
\hline 15 Negro Takeover-Domination Frame & 0 \\
\hline 16 Negro Vices Frame & 7 \\
\hline $\begin{array}{l}17 \text { Northern and Non-South Support and } \\
\text { Sympathy Frame }\end{array}$ & 0 \\
\hline 18 Northern Hypocrisy Frame & 0 \\
\hline $\begin{array}{l}19 \text { Protection of the Negro's Best Interest } \\
\text { Frame }\end{array}$ & 5 \\
\hline 20 Race Difference Frame & 1 \\
\hline 21 Racial Harmony Frame & 3 \\
\hline 22 Racial Preference Frame & 0 \\
\hline 23 Religious Frame & 18 \\
\hline 24 Savage African or Savage Negro Frame & 1 \\
\hline 25 Science Frame & 2 \\
\hline 26 States' Rights Frame & 2 \\
\hline $\begin{array}{l}27 \text { UN Tyranny-One World Government } \\
\text { Frame }\end{array}$ & 6 \\
\hline 28 Un-American Frame & 0 \\
\hline $\begin{array}{l}\text { SUM of } 6 \text { Highest }=126 \text { or } 77 \% \text { of Main } \\
\text { Frames }\end{array}$ & SUM TOTALS =164 \\
\hline
\end{tabular}

Table 5 Main Frames and Coding References for Elite Segregationist Rhetoric

\begin{tabular}{|l|l|}
\hline Main Frames & Main Frame Coding References \\
\hline 01 Agitator Frame & $\mathbf{4}$ \\
\hline 02 Anti-Communist Frame & $\mathbf{5}$ \\
\hline 03 Anti-Racial Miscegenation Frame & 0 \\
\hline 04 Anti-rightwing Militant Extremism Frame & 2 \\
\hline 05 Anti-Socialist, Liberal, Leftist Frame & 1 \\
\hline 06 Collapse or Destruction of Civilization & \\
Frame & 0 \\
\hline
\end{tabular}




\begin{tabular}{|c|c|}
\hline $\begin{array}{l}\text { 07 Discrimination Against or Anti-Whites } \\
\text { Frame }\end{array}$ & 0 \\
\hline 08 Freedoms Frame & 4 \\
\hline 09 Global Struggle for White Rule Frame & 0 \\
\hline 10 Historical Lessons Frame & 3 \\
\hline 11 Majority Opinion Frame & 0 \\
\hline 12 Nature Frame & 0 \\
\hline 13 Negro Contentment Frame & 0 \\
\hline 14 Negro intellectual Inferiority Frame & 0 \\
\hline 15 Negro Takeover-Domination Frame & 0 \\
\hline 16 Negro Vices Frame & 1 \\
\hline $\begin{array}{l}17 \text { Northern and Non-South Support and } \\
\text { Sympathy Frame }\end{array}$ & 0 \\
\hline 18 Northern Hypocrisy Frame & 0 \\
\hline $\begin{array}{l}19 \text { Protection of the Negro's Best Interest } \\
\text { Frame }\end{array}$ & 3 \\
\hline 20 Race Difference Frame & 1 \\
\hline 21 Racial Harmony Frame & 2 \\
\hline 22 Racial Preference Frame & 0 \\
\hline 23 Religious Frame & 0 \\
\hline 24 Savage African or Savage Negro Frame & 0 \\
\hline 25 Science Frame & 0 \\
\hline 26 States' Rights Frame & 24 \\
\hline $\begin{array}{l}27 \text { UN Tyranny-One World Government } \\
\text { Frame }\end{array}$ & 0 \\
\hline 28 Un-American Frame & 0 \\
\hline $\begin{array}{l}\text { SUM of } 6 \text { Highest }=43 \text { or } 86 \% \text { of Main } \\
\text { Frames }\end{array}$ & SUM TOTALS =50 \\
\hline
\end{tabular}




\section{REFERENCES}

Adams, Josh and Vincent J. Roscigno. 2005. "White Supremacists, Oppositional Culture and the World Wide Web.” Social Forces 84(2): 759-778.

Anderson, Carol. 2003. Eyes off the Prize: The United Nations and the African American Struggle for Human Rights, 1944-1955. Cambridge. U.K.: Cambridge University Press.

Bartley, Numan V. 1969. The Rise of Massive Resistance: Race and Politics in the South During the 1950’s. Baton Rouge: Louisiana State University Press.

Benford, Robert 1997. “An Insider’s Critique of the Social Movement Framing Perspective.” Sociological Inquiry 67(4): 409-430.

Blee, Kathleen M. and Kimberly A. Creasap. 2010. "Conservative and Right-Wing Movements.” Annual Review of Sociology 36: 269-286.

Bloom, Jack M. 1987. Class, Race and the Civil Rights Movement. Bloomington and Indianapolis: Indiana University Press.

Borstlemann, Thomas. 2001. The Cold War and the Color Line: American Race Relations in the Global Arena. Cambridge: Harvard University Press.

Braukman, Stacy. 2012. Communists and Perverts under the Palms: The Johns Committee in Florida, 1956-1965. Gainesville: University of Florida.

Buechler, Steven M. 1993. "Beyond Resource Mobilization? Emerging Trends in Social Movement Theory.” The Sociological Quarterly 34(2): 217-235.

Chafetz, Janet Saltzman. and Anthony Gary Dworkin. 1987. "In the Face of Threat: Organized Antifeminism in Comparative Perspective.” Gender and Society 1(1): 33-60.

Cunningham, David. 2004. There's Something Happening Here: The New Left, the Klan, and FBI Counterintelligence. University of California Press.

- 2013. Klansville, U.S.A.: The Rise and fall of the Civil Rights-Era Ku Klux Klan. Oxford and New York: Oxford University Press.

Day, John Kyle. 2014. The Southern Manifesto: Massive Resistance and the Fight to Preserve Segregation. Jackson: University Press of Mississippi.

Diamond, Sarah. 1995. Roads to Dominion: Right-Wing Movements and Political Power in the United States. New York, London: The Guilford Press.

Dudziak, Mary L. 2000. Cold War Civil Rights: Race and the Image of American Democracy. Princeton and Oxford: Princeton University Press.

Egerton, John. 1994. Speak Now Against The Day: The Generation Before the Civil Rights Movement in the South. New York: Alfred A. Knopf, Inc. 
Feldman, Glenn. 2009. "Southern Disillusionment with the Democratic Party: Cultural Conformity and "The Great Melding" of Racial and Economic Conservatism in Alabama during World War II.” Journal of American Studies 43(2): 199-230.

Finkleman, Paul. 1997. "Crimes of Love, Misdemeanors of Passion: The Regulation of Race and Sex in the Colonial South.” Pp. 124-138 in The Devils Lane: Sex and Race in the Early South, edited by Catherine Clinton and Michelle Gillespie. New York and London: Oxford University Press.

Fredrickson, Kari. 2001. The Dixiecrat Revolt and the End of the Solid South, 1932-1968. University of North Carolina Press; Chapel Hill in London.

Gamson, William A., Bruce Fireman, and Steven Rytina. 1982. Encounters with Unjust Authority. Homewood, IL: Dorsey.

Gerstle, Gary. 2001. American Crucible: Race and Nation in the Twentieth Century. Princeton: Princeton University Press.

Gelbman M. Shamira. and Jesse H. Rhodes. 2011. "Ideology Construction, Grassroots Mobilization, and Party Strategy in South Africa and the United States, 1934-1948.” Polity 43(2): 154-178.

Goffman, Erving. 1974. Frame Analysis: An Essay on the Organization of Experience. New York: Harper \& Row.

Goodwin, Jeff, James M. Jasper, and Francesca Polletta. eds. 2001. Passionate Politics: Emotions and Social Movements. Chicago and London: The University of Chicago Press.

Harvey, David. 2003. The New Imperialism. Oxford: Oxford University Press.

Horne, Gerald. 1998. Communist Front: The Civil Rights Congress, 1946-1956. Rutherford: Fairleigh Dickinson University Press.

Isaac, Larry. 2008. "Movement of Movements: Culture Moves in the Long Civil Rights Struggle.” Social Forces 87(1): 33-63.

Jackson Jr., John P. 2005. Science for Segregation: Race, Law, and the Case against Brown v. Board of Education. New York and London: New York University Press.

Jasper, James M. 2014. Protest: A Cultural Introduction to Social Movements. Cambridge: Polity Press.

Johnston, Hank. and John A. Noakes, eds. 2005. Frames of Protest: Social Movements and the Framing Perspective. New York, Oxford: Rowman and Littlefield Publishers, Inc.

Jenkins, J. C. and Charles Perrow. 1977. "Insurgency of the Powerless: Farm Worker Movements 1964-1972.”American Sociological Review 42:249-68. 
Katagiri, Yasuhiro. 2001. The Mississippi State Sovereignty Commission: Civil Rights and States' Rights. Jackson: University Press of Mississippi.

Klarman, Michael J. 1994. “Brown, Racial Change, and the Civil Rights Movement.” Virginia Law Review 80(1): 7-150.

_ 1994. "How Brown Changed Race Relations: The Backlash Thesis.” The Journal of American History 81(1): 81-118.

Lemmon, Sarah McCulloh. 1951. "The Ideology of the "Dixiecrat” Movement.” Social Forces 30(2):162-171.

Lewis, George. 2004. The White South and the Red Menace: Segregationists, Anticommunism, and Massive Resistance, 1945-1965. Gainesville: University Press of Florida.

. 2006. Massive Resistance: The White Response to the Civil Rights Movement. London: Hodder Education.

Lo, Clarence Y.H. 1982. "Countermovements and Conservative Movements in the Contemporary U.S.” Annual Review of Sociology Vol. 8: 107-134.

Lyton, Azza Salaama. 2000. International Politics and Civil rights Policies in the United States, 1941-1960. Cambridge, U.K.: Cambridge University Press.

McAdam, Doug. 1982. Political Process and the Development of Black Insurgency, 19301970.Chicago and London: University of Chicago Press.

— 1983. "Tactical Innovation and the Pace of Insurgency.” American Sociological Review. 48(6): 735-754.

McAdam, Doug, Sidney Tarrow and Charles Tilly. 2001. Dynamics of Contention. Cambridge: Cambridge University Press.

McAdam, Doug and Karina Kloos. 2014. Deeply Divided: Racial Politics and Social Movements in Postwar America. Oxford: Oxford University Press.

McCarthy, John D. 1986. "Prolife and Prochoice Movement Mobilization: Infrastructure Deficits and New Technologies.” in Social Movements and Re-source Mobilization in Organizational Society: Collected Essays, edited by Mayer N. Zald and John D. McCarthy. New Brunswick, NJ: Transaction Books.

Mckee, Seth C. 2008. "Rural Voters and the Polarization of American Presidential Elections" Political Science and Politics 41(1): 101-108.

McMillen, Neil. 1971. The Citizen's Council: Organized Resistance to the Second Reconstruction, 1954-1964. Urbana: University of Illinois Press.

McVeigh, Rory. 1999. "Structural Incentives for Conservative Mobilization: Power Devaluation and the Rise of the Ku Klux Klan 1915-1925.” Social Forces. 77(4):1461-1496. 
- 2009. The Rise of the Ku Klux Klan: Right-Wing Movements and National Politics Minnesota: University of Minnesota Press.

McVeigh, Rory and David Cunningham. 2012. "Enduring Consequences of Right-Wing Extremism: Klan Mobilization and Homicides in Southern Counties.” Social Forces 90(3): 843-882.

Meyer, David S. 2015. The Politics of Protest: Social Movements in America. New York, Oxford: Oxford University Press.

Meyer, David S. and Debra C. Minkoff. 2004. “Conceptualizing Political Opportunity.” Social Forces 82(4): 1457-1492.

Morris, Aldon. 2000. "Reflections on Social Movement Theory: Criticisms and Proposals.” Contemporary Sociology 29(3): 445-454.

Noakes, John A. 2000. "Official Frames in Social Movement Theory: The FBI, HUAC, and the Communist Threat in Hollywood.” The Sociological Quarterly 41(4): 657-680.

Oberschall, Anthony. 1973. Social Conflict and Social Movements. Englewood Cliffs, NJ: Prentice-Hall.

Oliver, Pamela E. and Hank Johnston. 2005. "What a Good Idea! Ideologies and Frames in Social Movement Research” Pp. 185-204 in Frames of Protest: Social Movements and the Framing Perspective, edited by Hank Johnston \& J. A. Noakes. New York, Oxford: Rowman and Littlefield Publishers, Inc.

Osha, Sanya. 2008. "Venus and White Desire” Transition 99: 80-93 Indiana University Press.

Olson, Joel. 2008. "Whiteness and the Polarization of American Politics.” Political Research Quarterly 61(4): 704-718.

Parkinson, Robert G. 2004. "First from the Right: Massive Resistance and the Image of Thomas Jefferson in the 1950s.” The Virginia Magazine of History and Biography 112(1): 2-35.

Platt, Gerald M. and Williams, Rhys H. 2002. "Ideological Language and Social Movement Mobilization: A Sociolinguistic Analysis of Segregationists’ Ideology.” Sociological Theory 20(3): 328-359.

Perry, Adele. 1997. "Fair Ones of a Purer Caste: White Women and Colonialism in NineteenthCentury British Columbia.” Feminist Studies 23(3): 501-524.

Pichardo, Nelson A. 1995. "The Power Elite and Elite-Driven Countermovements: The Associated Farmers of California during the 1930s.” Sociological Forum 10(1): 21-49. 
Piven, Frances Fox and Richard A. Cloward. 1977. Poor Peoples’ Movements. New York: Vintage Books.

Pleasants, Julian M. 1998. “Claude Pepper, Strom Thurmond, and the 1948 Presidential Election in Florida.” The Florida Historical Quarterly 76(4): 439-473.

Plummer, Brenda Gayle. 1996. Rising Wind: Black Americans and U.S. Foreign Affairs, 19351960. Chapel Hill: University of North Carolina Press.

ed. 2003. Window on Freedom: Race, Civil Rights, and Foreign Affairs, 1945-1988. Chapel Hill: University of North Carolina Press.

Record, Wilson. 1964. Race and Radicalism: The NAACP and the Communist Party in Conflict. Ithaca: Cornell University Press.

Rothman, Joshua D. 1999. "James Callender and Social Knowledge of Interracial Sex in Antebellum Virginia.” Pp. 87-113 in Sally Hemings and Thomas Jefferson: History, Memory, and Civic Culture, edited by J. E. Lewis and P. S. Onuf. Charlottesville and London: University of Virginia Press.

Santoro, Wayne A. and Gail M. McGuire. 1997. "Social Movement Insiders: The Impact of Institutional Activists on Affirmative Action and Comparable Worth Policies.” Social Problems 44(4): 503-519.

Schrecker, Ellen. 1994. The Age of McCarthyism. Princeton: Princeton University Press.

— 1998. Many Are the Crimes: McCarthyism in America. New Jersey: Princeton University Press.

Skrentny, John David. 1998. "The Effect of the Cold War on African-American Civil Rights: America and the World Audience, 1945-1968.” Theory and Society. 27(2): 237-285.

Snow, David A. and Robert D. Benford. 1992. "Master Frames and Cycles of Protest.” Pp. 133155 in Frontiers in Social Movement Theory, edited by Aldon Morris and Carol McClurg Mueller. New Haven, CT: Yale University Press.

. 2005. “Clarifying the Relationship between Framing and Ideology” Pp. 205-212. In Frames of Protest: Social Movements and the Framing Perspective, edited by Hank Johnston \& J. A. Noakes. New York, Oxford: Rowman and Littlefield Publishers, Inc.

Snow, David A., E. Burke. Rochford, Steven K. Worden, and Robert D. Benford. 1986. "Frame Alignment Processes, Micromobilization and Movement Participation.” American Sociological Review. 51: 464-81.

Stoler, Ann Laura. 1995. Race and the Education of Desire: Foucault's History of Sexuality and the Colonial Order of Things Durham: Duke University Press. 
- 2002. Carnal Knowledge and Imperial Power: Race and the Intimate in Colonial Rule. Berkeley and Los Angeles, California: University of California Press.

Tarrow, Sidney G. 2011. Power in Movement: Social Movements and Contentious Politics. Cambridge: Cambridge University Press.

Tilly, Charles and Sidney Tarrow, eds. 2007. Contentious Politics. Boulder: Paradigm Publishers.

Tilly, Charles. 2004. Social Movements: 1768-2004. Boulder: Paradigm Publishers. 1978. From Mobilization to Revolution. Reading, MA. Addison-Wesley.

Von Eschen, Penny. 1997. Race against Empire: Black Americans and Anticolonialism, 19371957. Ithaca: Cornell University Press.

Wallace, David J. 2013. Massive Resistance and Media Suppression: The Segregationist Response to Dissent during the Civil Rights Movement. El Paso: LFB Scholarly Publishing LLC.

Ward, Jason Morgan. 2011. Defending White Democracy: The Making of a Segregationist Movement and the Remaking of Racial Politics, 1936-1965.University of North Carolina Press.

Wesby, David L. 2005. “Strategic Imperative, Ideology, and Frames.” Pp. 217-235 in Frames of Protest: Social Movements and the Framing Perspective, edited by Hank Johnston and John A. Noakes. New York, Oxford: Rowman and Littlefield Publishers, Inc.

Webb, Clive. 2005. Massive Resistance: Southern Opposition to the Second Reconstruction. Oxford and New York: Oxford University Press.

Whitfield, Stephen. 1996. The Culture of the Cold War. Baltimore and London: The Johns Hopkins University Press.

Wilhoit, Francis M. 1973. The Politics of Massive Resistance. New York: George Braziller, Inc.

Williams, Johnny E. 2002. "Linking Beliefs to Collective Action: Politicized Religious Beliefs and the Civil Rights Movement” Sociological Forum 17(2): 203-222.

Woods, Jeff. 2004. Black Struggle Red Scare: Segregation and Anti-Communism in the South, 1948-1968 Baton Rouge: Louisiana State University Press.

Young, Robert C. 1995. Colonial Desire: Hybridity in Theory, Culture and Race. London: Routledge.

Zald, Mayer. 1996. “Culture, Ideology, and Strategic Framing.” Pp. 261-274 in Comparative Perspectives on Social movements: Political Opportunities, Mobilizing Structures, and Cultural Framings, edited by Doug McAdam, John D. McCarthy, and Mayer N. Zald. New York: Cambridge University Press. 


\section{NOTES}

\footnotetext{
${ }^{1}$ Waring, Thomas R. 1955. “Councils Spark New Life into Republic’s Principles.” The Citizens’ Council, December 1955, pp 2.

${ }^{2}$ Mississippi Department of Archives and History (Special Collections Citizens' Council description) ${ }^{3}$ Ibid

${ }^{4}$ The Citizens' Council: Official Paper of the Citizens' Councils of America [newspaper] Vol. 2, No. 5; February 1957; Page 3: "Letters to the Editor”;"Negro Citizen Writes”

${ }^{5}$ Ibid., Vol. 2. No. 2 November 1956; Page 4 "More Negro Teachers Lose Jobs As More Schools Are Integrated"

${ }^{6}$ Ibid., Vol. 2. No. 7 April 1957; Page 3: "A Manual for Southerners”

${ }^{7}$ Ibid., Vol. 1. No. 5 February, 1956; Page 3: "Mississippi Notebook: Negro Progress Is Big Credit to White South"

${ }^{8}$ Ibid., Vol. 1. No. 5 February, 1956; Page 3: "Mississippi Notebook: Negro Progress Is Big Credit to White South"

${ }^{9}$ Ibid., Vol. 3. No. 5 February 1958; Page 2: "Who Will Lead The Negro?”

${ }^{10}$ Ibid., Vol. 1. No. 5 February 1956; Page 3:"Mississippi Notebook: Negro Progress Is Big Credit to White South"

${ }^{11}$ Ibid., Vol. 2, No. 4 January 1957; Page 2: "Refuting The Big Lie"

${ }^{12}$ Ibid., Vol. 2, No. 5 February 1957; Page 3: "Reaping the Whirlwind—Integration in Washington Creating Ominous Unrest"

${ }^{13}$ Ibid., Vol. 2. No. 2 November 1956; Page 3: "Scandal of the Century! Facts of “Nation’s Model Schools" Shock Americans"

${ }^{14}$ Ibid., Vol. I, No. 6 March 1956; Page 1: "Disease, Prison Records Reflect Lapse in Morals Poses Real

Threat to the Welfare Of Our Entire Nation"

${ }^{15}$ Ibid., Vol. 3 No.9 June 1958; Page 3: "BAD BLOOD, CANT FLY"

${ }^{16}$ Ibid., Vol. 3, No. 5 February 1958; Page 3: "Letters to the Editor: Physician"

${ }^{17}$ Ibid., Vol. 1, No. 9 June 1956; Page 2: "Ten Cents Per Lady”

${ }^{18}$ Ibid., Vol. 1, No. 1 October 1955; Page 3 "Mississippi Notebook: NAACP Witch Doctors"

${ }^{19}$ Ibid., Vol. 1, No. 1 October 1955; Page 3 "Mississippi Notebook: NAACP Witch Doctors"

${ }^{20}$ Ibid., Vol. 1, No. 1 October 1955; Page 3 "Mississippi Notebook: NAACP Witch Doctors"

${ }^{21}$ Ibid., Vol. 1, No. 2 November 1955; Page 2 "Life Magazine Can Quote Scripture for Own Purpose"

${ }^{22}$ Ibid., Vol. I, No. 7 April 1956; Page 4 "Expose Another Giant Lie by New York’s Controlled Press"

${ }^{23}$ Ibid., Vol. 1, No. 5 February 1956; Page 2 "Editorial Opinion: The Truth is Painful”

${ }^{24}$ Ibid., Vol. 5, No. 1October 1959; Page 2 "We Like Them to 'Hate' Us”

${ }^{25}$ Ibid., Vol. 2, No. 9 June 1957; Page 2 "Segregation and Christian Love"

${ }^{26}$ Ibid., Vol. 1 No. 5 February 1956; Page 2“"Racist’ A Smear Word”

${ }^{27}$ Ibid., Vol. 2, No. 10 July 1957; Page 1“Are Some Church Leaders Betraying Their Country?”

${ }^{28}$ Ibid., Vol. I, No. 9 June 1956; Page 8 "Courageous Unions Defy "Negrophile Dictatorship"

${ }^{29}$ Ibid., Vol. 2, No. 5 February 1957; Page 4: "Fair Question"

${ }^{30}$ Ibid., Vol. 4, No. 1 October 1958; Page 1: "Left-Wing History Prof Bares Goal of 'Do-Gooders'”

${ }^{31}$ Ibid., Vol. 3, No. 3 December 1957; Page 3: "School Poll Has Socialist Trend"

${ }^{32}$ Ibid., Vol. 2, No. 5 February 1957; Page 4: "Women Of The South-Take Your Stand Now!”

${ }^{33}$ Ibid., Vol. 1, No. 1 October 1955; Page 2: "The Myth of World Opinion"

${ }^{34}$ Ibid., Vol. 1, No. 11 August 1956; Page 1: "Christian Love and Segregation”

${ }^{35}$ Ibid., Vol. 2, No. 1 October 1956; Page 3: "Can Private Schools Provide a Solution”

${ }^{36}$ Ibid., Vol. 1. No. 5 February 1956; Page 3: "Books Worth Reading”

${ }^{37}$ Ibid., Vol. 2, No. 5 February 1957; Page 4: "Women Of The South-Take Your Stand Now!"

${ }^{38}$ Ibid., Vol. 2, No. 5 February 1957 Page 1: "A Manual for Southerners”

${ }^{39}$ Ibid., Vol. 2, No. 5 February 1957 Page 1: "A Manual for Southerners"

${ }^{40}$ Ibid., Vol. 2. No. 6 March 1957; Pages 1 and 4: "A Manual for Southerners"

${ }^{41}$ Ibid., Vol. 3. No. 3 December 1957; Page 4: "Florida Minister Writes Congregation about Race"

${ }^{42}$ Ibid., Vol. 4. No. 1October 1958; Page 4: "Letters to the Editor" "Nevada"
} 
${ }^{43}$ Ibid., Vol. 6 No. 3 December 1960; Page 1:"White Rights Upheld”

${ }^{44}$ Ibid., Vol. 2 No. 12 September 1957; Page 3: "New York Fighting Race Integration”

${ }^{45}$ Ibid., Vol. 4 No. 11 August 1959; Page 4: "High Court Test Jeopardizes Basic Right of Private Property”

${ }^{46}$ Ibid., Vol. 1, No. 9 June 1956; Page 1: "First Anniversary Meet Hears Appeal by George Leader"

${ }^{47}$ Ibid., Vol. 1 No. 9 June 1956; Page 3; "Fair Practices-Or A Police State?”

${ }^{48}$ Ibid., Vol. 2 No. 3 December 1956; Page 4: "Rap “Minority Pressure”: Airline Workers Take Dim View of Integration Plans”

${ }^{49}$ Ibid., Vol. 4. No. 6 March 1959; Page 2“A Study in Brainwashing”

${ }^{50}$ Mississippi Department of Archives and History, “Citizens’ Council Forum,” Reel 089.

${ }^{51}$ Ibid., Reel 024.

${ }^{52}$ Ibid., Reel 024.

${ }^{53}$ Ibid., Reel 031.

${ }^{54}$ Ibid., Reel 016.

${ }^{55}$ Ibid., Reel 016.

${ }^{56}$ Ibid., Reel 045.

${ }^{57}$ Ibid., Reel 016.

${ }^{58}$ Ibid., Reel 045.

${ }^{59}$ Ibid., Reel 045.

${ }^{60}$ Ibid., Reel 001.

${ }^{61}$ Ibid., Reel 001.

${ }^{62}$ Ibid., Reel 001.

${ }^{63}$ Ibid., Reel 001.

${ }^{64}$ Ibid., Reel 018.

${ }^{65}$ Ibid., Reel 071.

${ }^{66}$ Ibid., Reel 015.

${ }^{67}$ Ibid., Reel 039.

${ }^{68}$ Ibid., Reel 020.

${ }^{69}$ Ibid., Reel 020.

${ }^{70}$ Ibid., Reel 070.

${ }^{71}$ Ibid., Reel 077.

${ }^{72}$ Ibid., Reel 090.

${ }^{73}$ Ibid., Reel 090.

${ }^{74}$ Ibid., Reel 090.

${ }^{75}$ Ibid., Reel 096.

${ }^{76}$ Ibid., Reel 027.

${ }^{77}$ Ibid., Reel 096.

${ }^{78}$ Ibid., Reel 033.

${ }^{79}$ Ibid., Reel 037.

${ }^{80}$ Ibid., Reel 037.

${ }^{81}$ Ibid., Reel 064.

${ }^{82}$ Ibid., Reel 085.

${ }^{83}$ Ibid., Reel 085.

${ }^{84}$ Ibid., Reel 085.

${ }^{85}$ Ibid., Reel 085.

${ }^{86}$ Ibid., Reel 023.

${ }^{87}$ Ibid., Reel 023.

${ }^{88}$ Ibid., Reel 030.

${ }^{89}$ Ibid., Reel 030.

${ }^{90}$ Ibid., Reel 091.

${ }^{91}$ Ibid., Reel 091.

${ }^{92}$ Ibid., Reel 036.

${ }^{93}$ Ibid., Reel 054.

${ }^{94}$ Ibid., Reel 054.

${ }^{95}$ Ibid., Reel 062. 
${ }^{96}$ Ibid., Reel 069.

${ }^{97}$ Ibid., Reel 073.

${ }^{98}$ Ibid., Reel 051.

${ }^{99}$ Ibid., Reel 089.

${ }^{100}$ Ibid., Reel 053.

${ }^{101}$ Ibid., Reel 053.

${ }^{102}$ Ibid., Reel 053.

${ }^{103}$ Ibid., Reel 053.

${ }^{104}$ Ibid., Reel 053.

${ }^{105}$ Ibid., Reel 013.

${ }^{106}$ Ibid., Reel 013.

${ }^{107}$ Ibid., Reel 093.

${ }^{108}$ Ibid., Reel 017.

${ }^{109}$ Ibid., Reel 087 .

${ }^{110}$ Ibid., Reel 087 .

${ }^{111}$ Ibid., Reel 048 .

112 Ibid., Reel 048 .

${ }^{113}$ Ibid., Reel 082.

${ }^{114}$ Ibid., Reel 019.

${ }^{115}$ Ibid., Reel 019.

${ }^{116}$ Ibid., Reel 014.

117 Ibid., Reel 021.

${ }^{118}$ Ibid., Reel 021.

${ }^{119}$ Ibid., Reel 021.

${ }^{120}$ Ibid., Reel 021.

${ }^{121}$ Ibid., Reel 021.

122 Ibid., Reel 021.

${ }^{123}$ Ibid., Reel 049.

124 Ibid., Reel 049.

${ }^{125}$ Ibid., Reel 049.

${ }^{126}$ Ibid., Reel 068.

${ }^{127}$ Ibid., Reel 068.

${ }^{128}$ Ibid., Reel 009.

${ }^{129}$ Ibid., Reel 029.

${ }^{130}$ Ibid., Reel 029.

${ }^{131}$ Ibid., Reel 029.

132 Ibid., Reel 029.

133 Ibid., Reel 029.

${ }^{134}$ Ibid., Reel 029.

135 Ibid., Reel 029.

136 Ibid., Reel 043.

${ }^{137}$ Ibid., Reel 043.

${ }^{138}$ Ibid., Reel 110 and 111.

${ }^{139}$ Ibid., Reel 040.

${ }^{140}$ Ibid., Reel 034.

${ }^{141}$ Ibid., Reel 034.

${ }^{142}$ Ibid., Reel 034.

${ }^{143}$ Ibid., Reel 034.

${ }^{144}$ Ibid., Reel 034.

${ }^{145}$ Ibid., Reel 034.

${ }^{146}$ http://archive.org/details/TheCitizensCouncilvol.2No.4-6January-march1957

${ }^{147}$ Mississippi Department of Archives and History

${ }^{148}$ University of Mississippi Libraries Digital Collections

http://clio.lib.olemiss.edu/cdm/landingpage/collection/citizens 
${ }^{149}$ Duke University. Ku Klux Klan collection, 1916-1987, Box 1, 1965 Oct. 21 The Klan Ledger: Special Jones County Edition.

${ }^{150}$ Ibid., 1966 Summer Klan Ledger-Com: Special Greenwood, Leflore County Edition. P. 2

151 Ibid., 1967 Apr. 21 The Christian Sentinel.

152 Ibid., 1967 Apr. 21 WAKE UP WAKE UP WAKE UP: DEAR WHITE AMERICAN.

${ }^{153}$ Ibid., 1966 April 20 Vol. 2, No. 5 Christian Conservative: The Christian Conservative Communique: A Confidential Intelligence Summary: The Negro Question.

${ }^{154}$ Ibid., 1966 Summer Klan Ledger: Special Greenwood, Leflore County Edition.

155 Ibid., 1966 Fall KKK Collection: People of Panoda County.

156 Ibid., 1966 July 7: Couldn’t It Be Wonderful To Return To The Freedom of 1776.

${ }^{157}$ United States Congressional Record. Proceedings and Debates of the $85^{\text {th }}$ Congress. Volume 103. Part 12. August 22, 1957 to August 30, 19'57. P. 16433

${ }^{158}$ United States Congressional Record. Proceedings and Debates of the $85^{\text {th }}$ Congress. Volume 103. Part 12. August 22, 1957 to August 30, 1957. P. 16435

159 United States Congressional Record. Proceedings and Debates of the $85^{\text {th }}$ Congress. Volume 103. Part 12. August 22, 1957 to August 30, 1957. P. 16412 
VITA

DEVON A. WRIGHT

Born, Toronto, Ontario, Canada

1999

B.A., History

Florida International University

Miami, Florida

2002

M.A., History

Florida International University

Miami, Florida

2014-2016

Teaching Assistant

Florida International University

Miami, Florida

2013-2017

Doctoral Candidate

Florida International University

Miami, Florida

\section{PRESENTATIONS}

Wright, Devon A.

"White Supremacist Ideology and Segregationist Frames in Cold War Context," presented at the Southwestern Social Science Association Annual Meeting, March 23-26, 2016.

Wright, Devon A.

"White Supremacist Ideology and Segregationist Frames in Cold War Context," presented at the Southern Sociological Society Annual Meeting, April 13-16, 2016.

Wright, Devon A.

“The Propaganda Media Campaign of the Citizens' Council” presented at the American

Sociological Association Annual Meeting, August 20-23, 2016.

Wright, Devon A.

"A Comparative Analysis of Conservative Right-Wing Protest Rhetoric in the Segregationist Resistance Era” to be presented at the upcoming American Sociological Association Annual Meeting, August 12-15, 2017. 